Florida International University

FIU Digital Commons

FIU Electronic Theses and Dissertations

University Graduate School

$10-24-2011$

\title{
Incursión en el Espacio Ontológico de las Novelas la Ninfa Inconstante de Guillermo Cabrera Infante y Todos se Van de Wendy Guerra
}

Rosa M. Inguanzo

Florida International University, ringu002@fiu.edu

DOI: $10.25148 /$ etd.FI11120909

Follow this and additional works at: https://digitalcommons.fiu.edu/etd

\section{Recommended Citation}

Inguanzo, Rosa M., "Incursión en el Espacio Ontológico de las Novelas la Ninfa Inconstante de Guillermo Cabrera Infante y Todos se Van de Wendy Guerra" (2011). FIU Electronic Theses and Dissertations. 533.

https://digitalcommons.fiu.edu/etd/533

This work is brought to you for free and open access by the University Graduate School at FIU Digital Commons. It has been accepted for inclusion in FIU Electronic Theses and Dissertations by an authorized administrator of FIU Digital Commons. For more information, please contact dcc@fiu.edu. 


\section{FLORIDA INTERNATIONAL UNIVERSITY \\ Miami, Florida}

\section{INCURSIÓN EN EL ESPACIO ONTOLÓGICO DE LAS NOVELAS LA NINFA INCONSTANTE DE GUILLERMO CABRERA INFANTE Y TODOS SE VAN DE WENDY GUERRA}

A dissertation submitted in partial of the

requirements for the degree of

DOCTOR OF PHILOSOPHY

in

SPANISH

by

Rosa M. Inguanzo

2011 
To: Dean Kenneth G. Furton

College of Arts and Sciences

This dissertation, written by Rosa M. Inguanzo, and entitled Incursión en el Espacio Ontológico de las Novelas la Ninfa Inconstante de Guillermo Cabrera Infante y Todos se Van de Wendy Guerra, having been approved in respect to style and intellectual content, is referred to you for judgment.

We have read this dissertation and recommend that it be approved.

$\begin{array}{r}\hline \text { Maida Watson } \\ \hline \text { Ana María Bidegain } \\ \hline \text { María Asunción Gómez } \\ \hline \text { Santiago Juan-Navarro, Major Professor }\end{array}$

Date of Defense: October 24, 2011

The dissertation of Rosa M. Inguanzo is approved.

Dean Kenneth G. Furton College of Arts and Sciences

Dean Lakshmi N. Reddi University Graduate School

Florida International University, 2011 
(C) Copyright 2011 by Rosa M. Inguanzo

All rights reserverd. 


\section{DEDICATORIA}

Para Alfredo Triff, con la mayor gratitud 


\section{AGRADECIMIENTOS}

Deseo agradecer a los miembros del comité por sus valiosas aportaciones a esta tesis doctoral: a la Dra. María Asunción Gómez por sus enfáticas sugerencias y por la fe que siempre me ha tenido desde que inicié mis estudios en FIU, a la Dra. Maida Watson por su apoyo y sus útiles recomendaciones bibliográficas, a la Dra. Ana María Bidegain

por su disponibilidad y acertadas indicaciones, y en especial, a mi director el Dr. Santiago Juan-Navarro por las minuciosas lecturas de los manuscritos y por indicarme el camino teórico a seguir, lo que ha significado una verdadera aventura intelectual.

También mi agradecimiento a la Dra. Marie D. Guiribitey y a la Dra. Omaira Hernández, por las complicidades académicas y la amistad que se urdió durante las largas horas de estudios compartidas. Finalmente he de reconocer la deuda de todo tipo que guardo a la memoria del Dr. Juan F. Márquez, su trascencia en mí a duras penas asoma en este esfuerzo. 


\section{ABSTRACT OF DISSERTATION \\ INCURSIÓN EN EL ESPACIO ONTOLÓGICO DE LAS NOVELAS LA NINFA \\ INCONSTANTE DE GUILLERMO CABRERA INFANTE Y TODOS SE VAN DE \\ WENDY GUERRA \\ by}

Rosa M. Inguanzo

Florida International University, 2011

Miami, Florida

Professor Santiago Juan-Navarro, Major Professor

This thesis examines the phenomenological projection of space in two Cuban novels: La ninfa inconstante (2008) by Guillermo Cabrera Infante (1929-2005), and Todos se van (2006) by Wendy Guerra (1970-). Both novels are paradigmatic of two generations of Cuban writers who portray the city of Havana as a backdrop against which to project socio-political and biographical narratives. To problematize ethical and political omissions in the novels, this work incorporates disciplines such as philosophy, urbanism, architecture, sociology and literary theory. Through the concepts of prominent phenomenologists, such as Gaston Bachelard, Martin Heidegger and Maurice MerleauPonty, amongst others, this study evaluates how space becomes a construction to ambivalent dynamics of truth telling within contrasting, suffocating sociopolitical contexts. In addition, it explores how these phenomenological spaces are defined in relation to power.

For instance, the Cuban Revolution, and its aftermath of more than 52 years, brings forth a sense of displacement and placelessness. The novels present and develop 
both authors' spatial consciousness (that we call "ontological space"), which is not necessarily a container of three-dimensional objects, but instead, fictional emergent constructions. This thesis concludes that literature can become a meaningful space to cope with unbearable realities. 


\section{ÍNDICE}

CAPÍTULO

PÁGINA

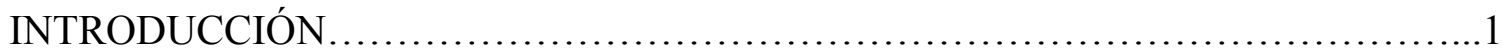

I. FILOSOFÍA DEL ESPACIO: UN REPASO HISTÓRICO.........................8

Platón y la filosofía del espacio................................................ 8

Neoplatónicos..................................................... 10

La Edad Media y Renacimiento........................................... 10

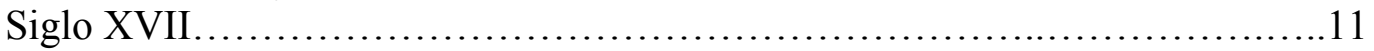

La Ilustración............................................................. 14

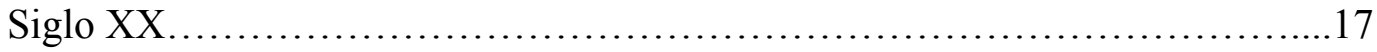

La poética del espacio de Gaston Bachelard y el espacio ontológico........... 24

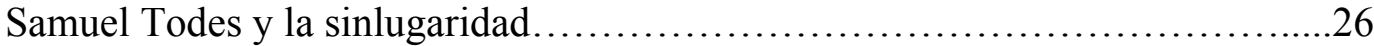

II. LA NINFA INCONSTANTE: EL ESPACIO ONTOLÓGICO COMO CINTA FÍLMICA DE LA MEMORIA ABOCADA EN LA CIUDAD....................29

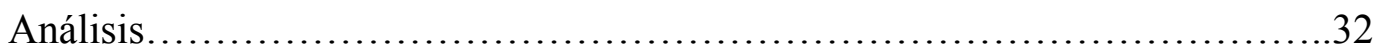

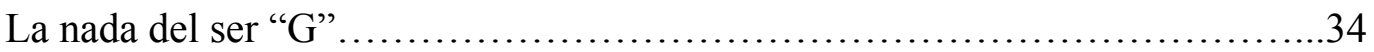

A. Modalidad "nostalgia-reflexiva"........................................ 48

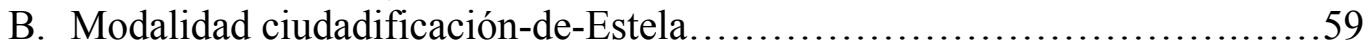

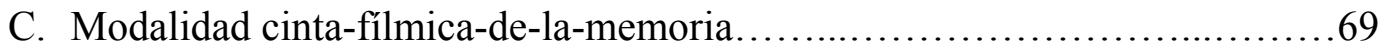

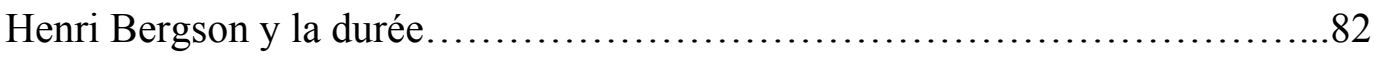

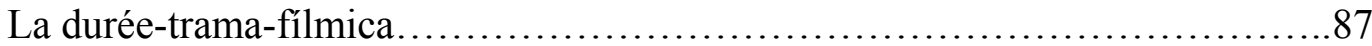

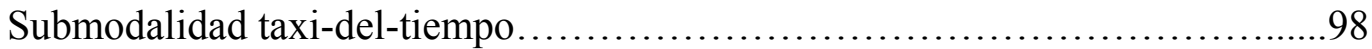

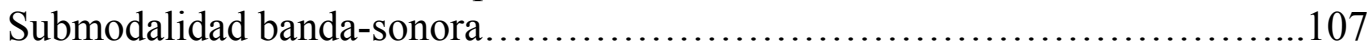

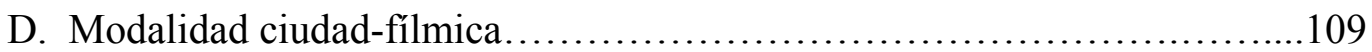

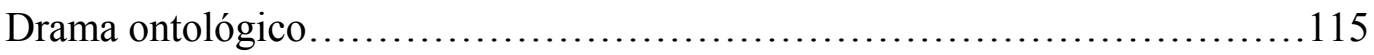

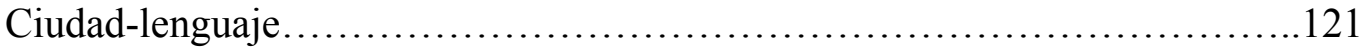

III. TODOS SE VAN DE WENDY GUERRA: ANULACIÓN DEL SER COMO MODALIDAD DEL SER ............................................. 130

El espacio ontológico constatado en el cuerpo...............................133

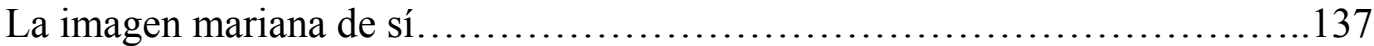

A. Modalidad transcripción privada en el espacio sitiado.......................138

La casa inestable de Nieve................................................. 140

Problematización de la "transcripción privada"................................142

Desde un análisis feminista, "trascripción privada" como discurso disidente....150

B. Anulación del ser como modalidad del ser: Nieve aprende el discurso de la unanimidad -la "transcripción pública".......................................169

Submodalidad ser Nieve y ser Diario. ¿Cómo hablar de espacio ontológico en un espacio sitiado?.

Submodalidad Todos se van............................................... 185

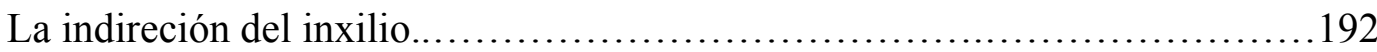


Antonio marca un punto de giro dentro de la dinámica indirección/inxilio.......205

CONCLUSIONES .............................................................219

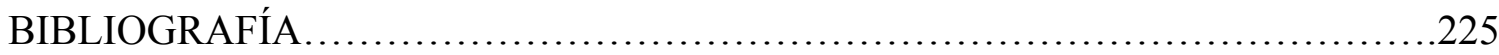

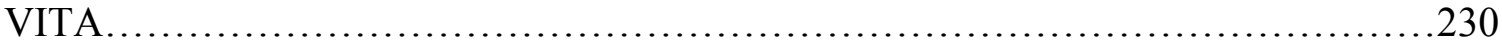




\section{INTRODUCCIÓN}

El presente estudio busca analizar lo que llamamos la proyección del espacio ontológico en las novelas La ninfa inconstante (2008) de Guillermo Cabrera Infante (1929-2005), y Todos se van (2006) de Wendy Guerra (1970- ). ¿A qué nos referimos? Para el filósofo Gaston Bachelard, en La poética del espacio (1957), la experiencia humana del espacio no es necesariamente un contenedor de objetos tridimensionales (lo que se conoce como espacio físico). Bachelard examina cómo es que el espacio acomoda la conciencia. Nuestro análisis parte de esa experiencia del espacio que se retiene como una marca síquica primordial. La fenomenología de Bachelard nos ayuda a comprender que una ensoñación o una memoria, tienen su lugar. Luego espacio, aquí indica un contenedor de entidades y relaciones, que pueden ser o no ser físicas. Más importante aún, Bachelard quiere acomodar en este espacio la conciencia del "soñador despierto", lo que él llama reverie.

¿Por qué el espacio? Porque todo lo sucede, sucede en un espacio. El espacio que nos ocupa en esta tesis es principalmente fenomenológico, no físico. A través del espacio fenomenológico puede comprenderse no solo el ser, sino su actividad creativa. Lo que Platón llama "forma" es una condición espacial mental, que mora en una idealidad llamada "eidos" (o sea, la idea está en un espacio). En efecto, sabemos que dos rectas paralelas nunca se encuentran en un infinito real (sino mental). Por otra parte, las cosas que nos rodean están “en” un espacio, sí, pero eso es solo el principio. La revolución copernicana de Immanuel Kant revoluciona el espacio, y nos ayuda a comprender que no hay espacio afuera, sin una categoría que haga posible su comprensión desde dentro. Esto es solo un paso antes de la fenomenología, que por primera vez "in-corpora" la idea del 
espacio. A partir de ahí no hay sentido espacial sin un cuerpo que lo encarne.

Fenomenológicamente hablando, el cuerpo es una brújula espacial. En éste punto hemos llegado al espacio como categoría mental/corporal, descubrimiento que es minuciosamente investigado por fenomenólogos.

De ahí que analicemos el espacio como modalidad, sea fenomenológica, literaria, sicológica o política.¿Qué es una modalidad? Un “topos”, una manera específica de explicar una cierta actividad corporal/mental, sea la obsesión topográfica de un personaje planteada como Modalidad cinta-fílmica de la memoria, o la ciudadificación- de-Estela, o la Submodalidad ser-Nieve y ser-Diario, o la Sumodalidad taxi-del-tiempo, etc.

El enfoque se enriquece cuando acometemos la ciudad de La Habana — donde transcurren las tramas de las dos novelas analizadas - con el aporte fenomenológico de Elizabeth Grosz, para quien el espacio urbano no está lejos de la idea de Bachelard, solo que ahora queda definido como un complejo ensamblaje interactivo de redes conectadas entre sí, frecuentemente "no integradas e inmediatas, un sinnúmero de actividades sociales dispares, procesos y relaciones, sean imaginarios o reales, proyectados, geográficos, cívicos o de relaciones públicas” (Grosz 244). Sugerimos por lo tanto la articulación de espacios literarios, psicológicos, históricos y cinemáticos, para categorías que hagan la experiencia espacial más abarcadora.

Nos hemos propuesto que nuestra tesis sea interdisciplinaria, sirviéndonos de discursos como la filosofía, la fenomenología, la crítica literaria, la arquitectura, el urbanismo y la sociología. Buscamos herramientas que resulten novedosas a la hora de abordar la novela, evitando teorías agotadas por el uso. Por lo que nos hemos planteado la 
embestida interdisciplinaria casi como una cuestión de método. ¿Cómo proceder en éste caso?

Empezamos a trabajar improvisando con intuiciones. En ambas novelas, para nuestra sorpresa, se revelan otros ángulos al margen de la crítica literaria. Por ejemplo, no resulta lo mismo analizar la novela como cine, que hablar de un personaje de novela aficionado al cine. No es lo mismo descomponer la topografía como memoria fílmica, que examinar a un personaje enfatuado con La Habana que recuerda. No es lo mismo considerar un diario un producto sociopolítico específico, que abordarlo como un simple texto literario. Es así como un enfoque nos va llevando a otro.

El Capítulo I se ocupa de la filosofía del espacio, ofreciendo el marco teórico del que partimos. En The Fate of Place (1997), de Edward S. Casey, reconocida autoridad en la filosofía del espacio, se sugiere que en cada espacio que se habita hay un lugar del ser. De ahí que el primer capítulo lidie con la historia de este concepto, desde Aristóteles y Platón hasta filósofos del espacio de la importancia de Martin Heidegger, Edmundo Husserl y Gaston Bachelard, entre otros.

Luego, haremos uso de algunos términos interdisciplinarios. Por ejemplo, para la obra de Cabrera Infante, los términos "nostalgia reflexiva" y "nostalgia restaurativa" que acuña Svetlana Boym en The Future of Nostalgia (2001), ayudan a entender las proyecciones del ser en los entornos físicos extraviados. La "nostalgia reflexiva" permite volver y disfrutar las contradicciones distantes en el tiempo, que es algo que hace Cabrera Infante desde su exilio en Londres. Aunque la Cuba de Guerra no ha pasado por la fase post-socialista (pero sí post-patronato soviético), que describe Boym, podría inferirse que el fenómeno del exilio/inxilio coloca a ambos autores en la etapa post- 
revolucionaria/post-socialista. Aquel entorno físico perdido, se reevalúa en ambas novelas desde el prisma de la añoranza, el reclamo, el abandono y la rectificación, en un proceso $^{1}$ que pudiera enmarcarse dentro de la "nostalgia restaurativa" cual la define Boym.

Otros términos han venido en nuestra ayuda. ¿Cómo explicar las omisiones rotundas del acontecer sociopolítico en La ninfa inconstante? El concepto de la mala fe (mauvaise foi) de Jean-Paul Sartre nos resulta más atractivo que explicaciones psicoanalíticas. Por otro lado, el estudio sociopolítico de la ciudad como cuerpo orgánico de Elizabeth Grosz, nos ha servido para dilucidar la relación ambivalente del protagonista "G" con su contrapartida fémina. Grosz habla de la ciudad como un cuerpo, por lo que su categoría de "ciudadificación" resulta necesaria para los fines de esta tesis.

El Capitulo II se ocupa de La ninfa inconstante de Cabrera Infante, llevando como punto de partida la relevancia del cine en la novela. Aunque este aspecto presente en casi toda la obra cabrerainfanteana haya sido ampliamente estudiado, esta vez abordaremos su recurrencia desde la idea del reverie de Bachelard, donde el ser se proyecta en una ensoñación — sugerimos, cual pantalla fílmica.

Por ejemplo, si el protagonista se traslada en un taxi en once ocasiones distintas de la trama, recurrimos al reverie, como vehículo que nos transporte a través del espaciotemporal de la novela. Veremos que un análisis se da la mano con otro. Del reverie pasaremos a la idea de la durée del filósofo temporista y vitalista Henri Bergson, donde la memoria es duración y preservación desde el presente.

\footnotetext{
${ }^{1}$ Boym explica el término "nostalgia" como una "emoción histórica" cuyas manifestaciones son efectos secundarios de la teleología del progreso de la experiencia toda (10).
} 
El fenómeno de la Revolución cubana (1959- ) es una presencia omitida en las novelas. No obstante, LNI ocurre mientras se gesta; TSV ocurre en su decadencia. La Habana paradigmática deviene sueño desmoronado de la utopía —el castrismo es una sustancia sin pasado ni futuro. Curiosamente, ambos autores sustraen a sus protagonistas del contexto sociopolítico e histórico - aún distintivamente. Tanto, que cabe preguntarse hasta qué punto es en la relación con el poder donde se definen los espacios.

El Capítulo III se centra en la novela de Guerra. Para ello es relevante el estudio de James Scott, Domination and The Art of Resistance (1990), el cual ofrece una perspectiva del individuo en relación con el poder, estableciendo dos transcripciones, una “transcripción pública" y una "transcripción privada" (2). Nos interesa analizar los códigos que transcriben el fenómeno de subordinación y sublevación al discurso del poder en Todos se van. Nos daremos a la tarea de analizar hasta qué punto Nieve, la protagonista de Guerra, en medio de esta negociación con el poder, avanza un discurso disidente frente a un Estado a todas vistas patriarcal y falocéntrico. La feminista Ileana Fuentes nos ayudará a problematizar la "transcripción privada" de Nieve desde un análisis de género.

La fenomenología de Edmund Husserl nos permite discernir cómo el espacio se constata en el cuerpo de la protagonista de Todos se van. Husserl propone que el espacio se confirma en el movimiento del cuerpo. Nieve ve cuartada su movilidad por un contexto socio-político opresivo, lo que determina un espacio igualmente angustioso.

El análisis literario de Anna Jackson, nos confirma que al enfrentarnos a la escritura del diario de Nieve, estamos lidiando con un medio de por sí tramposo. Pero 
descubrimos luego que en este caso, la realidad sociopolítica complica aún más las ambigüedades intrínsecas del diario como género.

Atisbamos que en el discurrir de ambos autores, salvando distancias temporales y particularidades discursivas y temáticas, se expresa la proyección del ser que Bachelard acuñaba en su análisis del espacio fenomenológico. Dicha proyección es reconstruida en La Habana vernácula moderna, en plena efervescencia urbanística, de los años 50 tardíos que recrea Cabrera Infante, alcanzando La Habana ruinosa del desaliento de los años 80 y 90 tempranos de Guerra. Mientras la fijación topográfica lanza al protagonista de $L a$ ninfa a una condición de ensimismamiento existencial, a Nieve, la evasión de su propia circunstancia, la preserva en medio de la vigilancia, la pérdida y el abandono.

El hecho de que sean narraciones en primera persona implica una subjetivación del espacio físico común a las dos novelas. Cabrera Infante presenta una ciudad intacta, milimétricamente narrada desde la memoria topográfica. De igual manera, la protagonista de Guerra, en los apuntes de su diario-novela, vive en una ciudad ${ }^{2}$ que tiene huellas generacionales (e incluye la generación de Cabrera Infante), recuerdos de recuerdos, fachada citadina desborrándose y redefiniéndose entre consignas socialistas y escombros. La ciudad de Cabrera Infante se detiene aquí, en el monólogo interior de Guerra, se paraliza. Desde la ciudad ruinosa, el espacio físico heredado, la novela de Guerra parece resumir la saga de los que se fueron (Cabrera Infante) y los que se quedaron (Guerra), es la ciudad de la anomia y la desidia. En Cabrera Infante el espacio fenomenológico es un

\footnotetext{
${ }^{2}$ H. Porter Abbot en su estudio sobre el género, evalúa lo "factivo" en la escritura de un diario como recuento de la acción, el poder factual de la experiencia narrada (Véase la página 43).
} 
refugio de la memoria fílmica. Guerra reclama un espacio vital restaurativo para sí, desde la orfandad y el abandono.

Consideramos que la importancia de este estudio radica en cinco aspectos principales: 1) Aunque la obra de Cabrera Infante ha sido ampliamente estudiada, su primera novela póstuma (que nos ocupa) aún no ha recibido suficiente atención. 2) Hasta donde llega nuestro conocimiento, la obra de Guerra no ha sido aún incluida en tesis alguna. 3) Tampoco se ha publicado un estudio comparativo entre ambos autores. El tema recurrente de la ciudad cabrerainfanteana merece un enfoque interdisciplinario en conexión con la obra Guerra. 4) Partiendo de la novela, nuestro estudio se vale de la categoría del espacio para problematizar aspectos ético-políticos de los autores, fundamentados en las omisiones de contexto de ambos protagonistas. 5) Este estudio desea contribuir al collage interminable de La Habana posible, partiendo de la díada habanera de Cabrera Infante y Guerra.

Nuestra condición de exiliados busca recuperar una Habana extraviada entre la ciudad mitológica de Cabrera Infante, y la ciudad post patronato soviético que, como fantasma literario (más que locación real), habita la protagonista de Guerra. 


\section{CAPÍTULO I}

\section{FILOSOFÍA DEL ESPACIO: UN REPASO HISTÓRICO}

El espacio es fundamental para la filosofía, ya que toda cosmogonía, así como la organización conceptual de toda ontología, comienza con el (o dentro de un cierto) espacio. Apuntemos que siempre ha existido una tensión entre el espacio general, como abstracción geométrico-matemática, y ese espacio particular que contiene cuerpos físicos. Dicha dicotomía fundacional griega, entre lo ideal/espacial platónico (que es el espacio como idea), y lo concreto/físico aristotélico, hace que la historia de la filosofía del espacio oscile entre dos polos.

Para los propósitos de esta investigación nos valdremos de la historia del espacio referida por Edward S. Casey en The Fate of Place (1997) Casey hace un estudio comparativo entre los filósofos del espacio, tomando como punto de partida la evasión del vacío, donde se apoya la dicotomía griega inicial, en particular desde Parménides de Elea (530 a. C, aprox.) y los atomistas, teniendo en cuenta que "crear, en primer lugar, es crear un primer lugar” (Casey 7). O sea, el espacio se crea en el vacío, el cielo es un espacio ideal y Dios crea del vacío.

\section{Platón y la filosofía del espacio}

El estudio más importante de Platón sobre el espacio está en el diálogo Timeo o de la naturaleza (360 a. C). Para Platón "lo que es", ha de estar en un lugar"

Es absolutamente necesario que todo lo que es sea en un lugar y ocupe algún espacio, y lo que no está en la Tierra ni en algún punto del cielo es

\footnotetext{
${ }^{3}$ Aunque Platón explica que todas las cosas de modifican y cambian de lugar. Esta dinámica universal no da lugar al espacio vacío: "El contorno del universo al envolver a todos los géneros de seres y tender por la naturleza de su forma esférica a concentrarse en él mismo, comprime y no permite que ningún espacio permanezca vacío" (Diálogos 693).
} 
nada $[\ldots]$ El ser, el espacio y la generación son tres principios distintos y anteriores a la formación del mundo. (Diálogos 688)

De modo que puede hablarse de una necesidad espacial que antecede a la necesidad temporal. Sin embargo, la idea de "receptáculo" que plantea no es estrictamente material. Más que algo físico, se trata de un espejo de lo físico (Casey 32$33)^{4}$. Dicho espacio platónico posee las siguientes características: 1- En tanto que receptáculo no es un vacío, sino “plenario” (lleno de sí). 2- Está localizado en regiones dentro de ese espacio. ¿Por qué? Porque lo que es, está en una situación específica. 3Consiste en regiones primarias, donde la sensibilidad elemental se agrupa en ensamblajes, las formas se agrupan a sí mismas. Es decir, se trata de una región incluyente tanto de lo que contiene como del contenedor (un espacio que contiene lo que hay dentro de sí, y se contiene a sí).

Lo que plantea un punto de partida contrario al su maestro Aristóteles, para quien el espacio es un contenedor físico, la oposición al caos amorfo. Este interés espacial casi puntual (que refiere a puntos de ubicación) de Aristóteles, determina un espacio particular, puntualizado, localizado, un "lugar". De manera que "lugar" es espacio ostensible (Casey 51). En Aristóteles existen dos tipos de lugares: el lugar común, o topos koinos, donde radican los cuerpos, y un lugar especial o topos ideos, que es el originario en que todo cuerpo está contenido. Utiliza la analogía de espacio como "nave" (en capacidad de contener). La nave es el límite periférico que circunscribe algo (Casey 54).

\footnotetext{
${ }^{4}$ Para comprender el espacio ideal, tomemos como ejemplo la geometría euclideana: Idealmente, ¿qué es una línea?, la intercepción de dos puntos; ¿qué es un triángulo?, la intercepción de tres lados adyacentes. Pero el estacionamiento triangular del mercado (cualquiera que este sea), es la instanciación de lo ideal, la concretación de la idea geométrica. (Véase Rundle 224-30)
} 
La diferencia entre Aristóteles y Platón es que para el segundo, el espacio (chora) es omni-recipiente. Platón siendo idealista, piensa en la forma; Aristóteles, el realista, mira el contenido. Es famoso el axioma aristotélico: "De la misma manera que todo cuerpo está en un lugar, en todo lugar hay un cuerpo" (Casey 58). Por el contrario, para Platón no todo lugar tiene un cuerpo, es decir, un "receptáculo" no tiene por qué contener un cuerpo físico. Se trata del receptáculo de la postulación abstracta de la geometría.

\section{Los neoplatónicos}

Para los neoplatónicos en el siglo III d. C., el lugar es un cuerpo, pero se trata de un cuerpo inmaterial: el alma. Al menos debemos calificar éste último. Primero, aparecen numerosos "lugares". Escribe Plotino (205-70 d. C.) en las Enéadas (compiladas por su discípulo Porfirio): "El lugar del mundo inteligible, es el lugar de la vida, es decir, el principio del alma y del intelecto" (Casey 89). De ahí que Jámblico (250-325 d. C. aprox.), enumere poderes plenipotenciarios para el lugar, a saber: soportar, elevar y llenar. Este lugar, lejos de ser pasivo, tiene su propia causa (eitia). Ya para el siglo V d. C., los neoplatónicos definen "lugar" como dinámico y activo, intelectivo e indivisible. Dice Proclo (410-85 d. C.): "Lugar es un cuerpo indivisible" (Casey 93). De modo que para los neoplatónicos, ahora el lugar puede sostener, preservar el orden, elevar y reunir.

\section{La Edad Media y el Renacimiento}

En la Edad Media el espacio se hace infinito. El filósofo y teólogo Tomás de Aquino (1224), fundador de la escuela tomista retoma la espacialidad aristotélica en cuanto que alma y cuerpo forman una única sustancia corporal (en el mundo, por tanto espacial) y espiritual — pero para él esa sustancia es inmortal. 
Aquí la filosofía es coaccionada por la religión y la teología ${ }^{5}$ — también la teología de Aquino la enriquece. Si bien el modelo aristotélico explica el universo existente, ¿qué pasaría si Dios decidiera cambiar ese orden? ¿No son posibles otros mundos? Reparemos en que hasta ahora, y han transcurrido 2000 años, solo un filósofo ha visto el espacio como algo concreto: Aristóteles.

Hay un momento a finales de la Edad Media en que ese modelo espacial geocéntrico se expande a un universo infinito en la imaginación (secundum imaginationem); Nicolás Oresme (1323-82), uno de los principales creadores de la ciencia moderna, lo describe de esta manera: "El espacio de que hablamos es infinito e indivisible, y es la inmensidad de Dios y es Dios mismo" (Casey 111). Notemos que ellos están viendo la eternidad en términos espaciales. Nuestro modelo tolomeano, hasta llegar aquí, era geocéntrico. Pero el lugar de ese cielo infinito que contemplaban los filósofos, sigue siendo el cielo dependiente de la tierra.

Entonces, para el siglo XIV el espacio pasa a ser un conjunto de relaciones de las esferas celestes que giran en torno a la tierra, abriendo posibilidades a otros mundos. El "lugar" desaparece para convertirse en un espacio infinito. Estos presupuestos predominan inalterables durante el Renacimiento. De ahí el dictado de Giordano Bruno (1548-1600): "El infinito se ha hecho una necesidad imperativa" (Casey 106).

\footnotetext{
${ }^{5}$ Sólo a tres años de la muerte de Tomás de Aquino - el pensador que, en su modelo racional, había señalado la necesidad del espacio infinito_-, en París, liderado por la cúpula de la iglesia católica y respaldado por los teólogos de La Sorbona, se emitieron 219 condenas a doctrinas que negaban o limitaban el poder de Dios, que "incluían el poder de mover o mudar al mundo a un lugar diferente al lugar que ocupa" (Casey 105-07). Las condenas dan carta blanca a la exploración de los espacios infinitos. Por ello 1277 se cree el comienzo de la ciencia moderna, ya que de ésta forma se abre el camino para la exploración de los mundos posibles.
} 


\section{Siglo XVII}

Con el Racionalismo del siglo XVII, Descartes, Newton, Leibniz, entre otros, reafirman la idealidad del espacio — refiriéndose ahora al espacio puro de las ciencias exactas (la mejor diferenciación para un espacio físico-matemático; no podía ser de otro modo, los tres son matemáticos). Pero este espacio físico-matemático también tiene un componente teológico que lo adhiere a la omnipresencia de la creación divina.

Para René Descartes (1596-1650) no puede existir espacio sin un cuerpo que lo ocupe. Racionalista al fin, su concepto del espacio está dado en relación a la "extensión” de los cuerpos. Para Descartes la idea del vacío es imposible: toda materia se extiende de manera inconmensurable. Dios es un todo. En este nuevo paradigma cartesiano, Dios no puede ser el sujeto de las propiedades que percibimos en el espacio. ¿Por qué no? Porque Dios no es imaginable ni distinguible en formas o partes medibles. Para Descartes Dios es una sustancia, pero no es una sustancia extendida: "Dios no es imaginable o distinguible ni en forma ni partes medidas" (Descartes 240).

Visto así, toda instancia del espacio es material, ya que la materia ocupa el espacio y el espacio es materia que contiene. El "lugar" siempre está subordinado al espacio: “Todos los lugares están llenos de cuerpos. Nada tiene un lugar perdurable, salvo que sea en nuestra mente"6 — dice Descartes. Además: "Cuando un cuerpo deja un lugar, siempre entra en otro lugar con otro cuerpo, y así sucesivamente hasta el último, el cual en ese mismo instante ocupa el lugar desocupado por el primero" (Casey 157). Para

\footnotetext{
${ }^{6}$ Véase el Capítulo 7 de Casey, dedicado a Descartes, (151-61). Casey trae esta cita en la página 151, extraída de Principles of Philosophy (1644) de Descartes.
} 
Descartes el espacio es un híbrido volumétrico y situacional, cuya extensión, no obstante, puede ser una extensión espiritual.

Un poco influenciado por la física aristotélica, para Isaac Newton (1642-1727) el espacio es absoluto, inamovible, inteligible y no relacionado con nada externo ${ }^{7}$. Absoluto en cuanto a que para Newton el vacío está lleno de Dios, y ese vacío/Dios es omnipresente en el espacio físico. Inamovible en cuanto a que el espacio sólo puede establecerse cuando el cuerpo que lo ocupa se establece, quedando quieto en el espacio. Notemos que a diferencia de Descartes, para Newton sí hay vacío. El vacío para Newton: "No puede existir sin Dios, aunque puede haber sido o puede convertirse en espacio completamente vacío" (Rundle 6). Casey, para explicar a Newton trae una interpretación del filósofo Alfred North Whitehead: "Tan pronto como uno se instala, de cualquier forma en cualquier lugar, lo uno, es decir un cierto lugar definitivo en tiempo/espacio, esto entraña establecer una relación corporal particular hacia ese tiempo/espacio; al decir está aquí, en éste lugar" (Casey 138) (énfasis del autor).

Otro paradigma ofrece Gottfried Leibniz (1646-1716) — para él el espacio es, 1) relativo, abstracto, ideal y posible, 2) el lugar se pierde en la infinitud del espacio, 3) el lugar se pierde en la relatividad de un espacio constituido por un conjunto estructurado de relaciones (Casey 175). Relacional, en cuanto a que reduce el espacio a la posición, especie de coordenada abstracta, donde posición depende sólo de las relaciones exteriores de un punto del espacio comparado a otro punto del espacio, o un conjunto de puntos (Casey 171). Por ejemplo, digamos que el sol está a X distancia de la tierra—su lugar

\footnotetext{
${ }^{7}$ Véase el análisis del espacio absoluto newtoneano, por Bede Rundle en Time, Space, and Metaphysics (2009), páginas 6-9.
} 
pues, es una ubicación en relación a la tierra. Para Leibniz, espacio y tiempo son construcciones lógicas productos de los cuerpos y los eventos (Rundle 9).

\section{La Ilustración}

En el Neoclasicismo del siglo XVIII, el arte y la literatura reflejan una preocupación por la posición específica de los objetos en un espacio. Ahora podemos hablar del espacio del poder absoluto (sea real o aristocrático), representado por la gran monarquía. Trátese del Rey y sus súbditos, el doctor en la clínica, el criminal en la cárcel, la monja en el monasterio — en este régimen cada persona está posicionada en un lugar. Este orden neoclásico reorganiza y reparte el cuerpo en el espacio/lugar. Se articula aquí un espacio sociopolítico.

De ahí surge la idea del panopticón de Jeremy Bentham (1748-1832): la prisión modelo sirve como paradigma del lugar para verlo todo, donde nada queda fuera de la vista del custodio localizado en un punto central elevado, con acceso visual directo a cada celda de la estructura/espacio (Foucault 195-228). El propósito de panopticón es ver sin ser visto. Es saberse visto—-lo que presupone una internalización del saberse vigilado. Panopticón es paradigma de un espacio analítico, laboratorio de poder que ahora se hace modelo funcional, arquitectura aplicable a cualquier lugar, con una función generalizada. Esta idea fue propuesta por Bentham al gobierno británico en 1787, idea en la que el filósofo insistió hasta que fue eliminada por el Rey 1803.

¿Qué implicaciones tiene el panopticón en nuestro análisis de espacio/lugar? Este espacio vigilado implica la destrucción de "lugar", porque ahora todo lugar es un lugar vigilado, localizado, instrumentalizado (donde no hay nada orgánico), donde se desmantela la posición orgánica en el espacio: éste es el "sitio". Precisamente Foucault 
empieza analizando el panopticismo trayendo la descripción de cierta ciudad del siglo XVII azotada por una plaga, donde se toman medidas de control preventivas:

Es espacio segmentado, inmóvil, congelado. Cada individuo está fijo en su lugar.

Si el individuo se mueve lo hace a riesgo de su vida, del contagio o del castigo. La inspección está funcionando incesantemente. La mirada alerta está en todos lados [...] Todo el mundo permanece encerrado en su cueva, todo el mundo a la ventana, respondiento por su nombre y reportándose cuando se le solicite.

(Foucault 195-96)

Sobre este aspecto, Casey apunta que "sitio" es homogeneidad, planiformidad, serialidad, es deshacer el lugar, desmantelarlo, a cambio de posiciones precarias, predelineadas y precisas:

Precarias porque están en relación a otras posiciones, que son a su vez dependientes de otras posiciones (en el panopticón, los carceleros son observados por los vigilantes, que a su vez son observados por los supervisores; finalmente, todos están sujetos a inspección). (Casey 186)

Como se será más tarde, daremos la palabra "sitio" a aquel lugar que es vigilado, como La Habana de Wendy Guerra en Todos se van (2006), en la que el individuo ha de cuidarse lo que se habla para que no le lean los labios. Donde los vigilantes de La Seguridad del Estado, los vecinos de los Comités de Defensa de la Revolución y demás ramas gubernamentales fungen como informantes. Ėste es el lugar sitiado, en estado de sitio $^{8}$.

\footnotetext{
${ }^{8}$ La Seguridad del Estado cubana - calco de las tenebrosas Stassi de la República Democrática Alemana (RDA) y KGB de la Unión Soviética (URSS) - asegura que las acciones de todo el mundo sean vigiladas, fichadas, coartadas.
} 
Ya para finales del siglo XVIII, Immanuel Kant (1724-1804) viene a reconciliar los postulados racionalistas (Descartes, Newton, Leibniz) y empiricistas (John Locke, David Hume, George Berkeley). Para Kant el espacio es una categoría fundamental del conocimiento, y el conocimiento procede de la razón y de la experiencia. Para él, el espacio no está afuera del sujeto, está en la mente. El espacio pertenece a la mente, siendo la percepción espacial una forma pura de intuición (Stöker 165-66)9.

De acuerdo al filósofo alemán, es posible proyectar/representar espacios dentro de un espacio infinito. Pero éste proceso toma lugar en nuestra mente. Se trata de un orden $a$ priori, especie de estructura pre-existente que hace posible dar sentido al fenómeno físico. Dice Kant: "En la mente y en la intuición exterior que precede a los objetos en sí mismos, y en los cuales el concepto de estos objetos es determinado a priori" (Kant, Crítica 70).

El espacio para Kant es mental, en cuanto a que la mente le da sentido a mis experiencias (del espacio), ya no porque suceda en la mente: sucede ahí y en el universo. Así explica la intuición a priori del espacio:

Para que una sensación sea referida como algo fuera de mí (de una región del espacio en la que me encuentro), y similarmente para que pueda representarla como estando fuera, y/o a lo largo de otra, y/o correspondientemente en lugares distintos, la representación del espacio debe ser presupuesta. (Casey 193)

\footnotetext{
${ }^{9}$ Un ejemplo kanteano para comprenderlo sugiere que imaginemos una habitación amueblada. Luego, imaginémosla sin muebles. Bien, ahora imaginemos los muebles sin espacio. Solo el último intento es fallido; lo que prueba que el espacio es una categoría mental.
} 
Kant le presta especial atención a la experiencia como elemento clave a la hora de establecer la conexión entre cuerpo y espacio. Dice que todo espacio es un punto, un solo espacio, siendo el espacio absoluto el universo. Aunque también distingue "regiones" a medio camino entre el espacio relacional inmediato que ocupamos, y la concepción absolutista del espacio ${ }^{10}$. Comprendamos la contribución kanteana permitiéndonos la siguiente analogía: la razón a priori es análoga al disco duro de la computadora, y la experiencia viniera a ser los programas agregados a la misma - las categorías mentales vienen a ser el disco duro al que se le agrega la experiencia. Para Kant la experiencia del espacio es ambas, racional y empírica, y esta reconciliación de ambos postulados es su gran aporte a la filosofía del espacio.

El paradigma ilustrado se sostendrá hasta el siglo XX.

\section{Siglo XX}

En el siglo XX nos detendremos en tres figuras que cambian el paradigma que les precede: Edmund Husserl, Martin Heidegger y Maurice Merleau-Ponty. Con ellos el espacio se in-corporiza. Vuelve el "lugar," pero ahora a través del cuerpo.

Edmund Husserl (1859-1938) caracteriza la experiencia en el mundo como "Lebenswelt" (“mundo-vivido"): Todo cuerpo está en una relación perceptiva con su espacio circundante. A su vez, esa participación sensorial le da sentido a la vida. Para Husserl, "la experiencia humana más profunda" del mundo, no es solamente espacial sino también temporal, considerando que el fenomenólogo tiene el deber que explorar la espacialidad y la temporalidad del cuerpo: "Todo lo que encuentro se da a sí como

\footnotetext{
${ }^{10}$ Véase el Capítulo 9 de Casey, sección IV, dedicado a Kant, las páginas 187-93.
} 
concertado alrededor del cuerpo con que percibo. Gracias a mi cuerpo estoy en el centro de las cosas: Yo mismo" (Casey 217) - dice Husserl. Lo que deja al cuerpo como centro del espacio: "Ich-zentrum" ("yo-centro") 11.

A la pregunta ¿qué relación existe entre mi cuerpo y el espacio? La respuesta es cenestesia $^{12}$, que para el filósofo es la experiencia interior del movimiento de mi cuerpo, mientras se siente a sí mismo moverse y pausar en un momento determinado. En Husserl, la experiencia requiere que se perciba el movimiento espacial, y en el movimiento se constata el cuerpo en el espacio.

Con Martin Heidegger (1889-1976) llegamos al "lugar" mediante una “indirección”. Es decir, tal "lugar" se ubica en un punto medio entre el cuerpo y la mente (Casey 244). Heidegger plantea que el "lugar" puede darse alrededor del cuerpo y fuera del cuerpo. O sea, al "lugar" se llega a través y fuera del cuerpo mismo. De ahí la idea de “Dasein” (“Ser-ahí”), que es residir, estar, como si el mundo fuera la casa, la morada del ser. ¿Cómo ser/estar ahí? En lo primordialmente familiar, es decir, las relaciones preobjetivas e inmediatas de "Dasein", aspecto este que Heidegger explica como "ser a la mano" (“Zuhandenheit") y el "estar-ahí" ("Vorhandenheit") (Heidegger, El ser 65) ${ }^{13}$.

\footnotetext{
${ }^{11}$ De acuerdo a lo interpretado por Casey. Véase en TFOP, las páginas 217-18.

12 'Mi cuerpo -en particular, digamos, esta parte del cuerpo llamada 'mano' -se mueve en el espacio; [pero] la actividad del movimiento mismo, la 'cenestesia', significa eso que se incorpora junto al movimiento del cuerpo" (Casey 215-16). El diccionario define cenestesia como la sensación general de la existencia y del estado del propio cuerpo, independiente de los sentidos externos (Véase en el Diccionario de la Real Academia Española. Vigésima Primera Edición).

${ }^{13}$ Heidegger usa el término "ser a la mano", que es una manera de hacerle frente al mundo, y "estar ahí" que es reparar en lo que está "a la mano" (una actitud de reacción a la contingencia), y que son sin duda conceptos importantes en el enfoque que Heidegger da al espacio (Being 65). Pero hemos resumido aspecto fundamentales de "Dasein": En la descripción del ser, en vez de usar la palabra ser, Heidegger utiliza "Dasein" (Das- es el espacio que se abre, e ilumina, estar-ahi), pero evita el uso fenomenológico que se da al vocablo ser. Heidegger quiere ir a un análisis ontológico; o sea, el ser en tanto que ser -y se hace de otros tipos de herramientas para abordar el fenómeno, porque el ser fenomenológico oculta algo, que es
} 
Entonces el mundo se desenvuelve en una cierta inmediatez que es primaria para la espacialidad de "Dasein", en "el servir para", que es el propósito digamos ontológico de relacionarnos en el espacio: “Uno no puede idearlo como 'ser a la mano' como una cosa corpórea (como el cuerpo humano) 'dentro' de una entidad 'a la mano"”'14. Con “Dasein", Heidegger distingue al "ser" del cuerpo que reside: "In-Sein” (“estando-ahí”), siendo este una existencialidad de "Dasein" (es decir, una manera de interrogarlo, de analizar "Dasein" en sí mismo). Notemos que para Heidegger el tiempo hace posible el espacio.

A diferencia de Kant, el espacio para Heidegger no está localizado en el sujeto, si no que está en el mundo. Aunque debido a esa actitud de familiaridad ese espacio se torna cotidianamente invisible. No obstante, veremos que el Heidegger tardío admite la posibilidad del espacio como una especie de pensamiento ("Denken") (Casey 271). Lo importante aquí es que para Heidegger, el ser existe más allá del espacio/lugar:

Para entender el problema ontológico del espacio, es importante que la cuestión del ser sea liberada de la estrechez de todo concepto del ser que

\footnotetext{
"Dasein"—otra complejidad, según el filósofo. "Dasein" significa: el ser, encierra las notas fundamentales de ser: 1. su existencialidad - que es el ser (Dasein) constatado en el mundo, estar-en-el-mundo, y su devenir (al futuro), su utilidad y la "Cura" (Sorge) de la existencia que es la actividad diaria de cualquier persona; 2. su factualidad (Faktizitat), es estar-en-el-mundo y reconocerse en la situación inevitable, estar arrojado en la vida ante designios que no se han escogido; 3. la caída ("Verfallen"), es estar-con-los-otros, no tiene connotación moral, es la huida del ser, la mala fe, la auto-enajenación- - Dasein" se pierde en los otros — que Heidegger llama "habladurías". Nuestro resumen aquí, proviene de la edición en inglés de Being and Time, aunque nos hemos asistido en las traducciones de los términos con la versión en español El Ser y el Tiempo (originalmente publicado en 1927). Véase nuestra bibliografia.

${ }^{14}$ Valga la siguiente cita para entender la relación que establece Heidegger entre el ser y el espacio: "Dentro' se deriva de "innan" (que es residir, "habitare," "morar"). Es decir, "me es familiar," "busco algo.” [...] La expresión ‘bin' va conectada con 'bei', y ‘Ich bin' ['yo soy'] (yo vivo o resido en, al borde del mundo que me es familiar). "Ser" ('Sein'), infinitivo de 'Ich bin' (cuando se entiende como existentiale), significa "estar en" como decir: "estar familiarizado con [...]" "Estar dentro es una forma de existencial de Dasein, el cual tiene a su ser como estado esencial" (Casey 245-46). Vale aclarar que Heidegger llama existentiale a una manera de análisis ontológico que hace posible que podamos hablar del ser en cualquier lugar.
} 
lo convierta meramente en algo disponible en el espacio (en lo que toca al fenómeno espacial mismo). Debe ser redirigido hacia clarificar las posibilidades del ser en general. (Casey 253)

De la cita puede entenderse que para el filósofo el ser es un concepto vasto relacionado al espacio físico, pero nunca limitado al mismo. El Heidegger tardío en el ensayo "La Cosa y Construir, Habitar, Pensar" (1936), define una condición íntima entre "región" ("Gegend") a la que regresaremos más abajo, y su categoría "ser a la mano" (“Zuhandenheit”) que no es más que una manera pre-automática de interactuar con la realidad. Pero anotemos que, de acuerdo a Casey, "lugar" para Heidegger también es “región”, es decir, un espacio específico, acotado.

Más importante aún es la exploración que la acepción "lugar” tiene para el arte en general. De hecho, el aspecto que le toca a la obra de arte es crucial para la comprensión de "lugar" en el Heidegger tardío. Es por ello que en su ensayo "El origen de la obra de arte" (1937), la pregunta crucial no es el "qué" del arte, sino el "dónde" de la obra de arte. Este "dónde" en que ocurre la obra de arte (y por tanto "la verdad del arte"), es descrito como "claro en el bosque".

Se ha hablado del "conflicto" ("Urstreit") entre lo que se muestra y lo que se oculta, pero lo fundamental es que existe una abertura, es decir, "se hace lugar" para un espacio del arte. Este es un lugar de tensión. Esa fisura frágil hace posible no sólo la forma artística sino el "dónde" reside "la verdad del arte". Heidegger lo explica así: La lucha que se asienta en la tierra y queda fija es forma, "Gestalt". Es decir, la verdad queda emplazada en la forma. Esta grieta es el ajuste del brillo de la verdad. Lo que llamamos forma ("Gestalt") siempre se debe 
pensar en término de su lugar ("Stellen”) particular, el enmarcado en que ocurre y se establece. (Casey 267)

Del análisis anterior sale la idea de "región” (“Gegend”), que Heidegger elabora por los años 50, como el lugar del "claro en el bosque". "Región” es superada por el gerundio "regionando" y “eso-que-regiona" (Casey 271). La implicación espacial ahora abarca no sólo lo material y lo físico, sino también el pensamiento mismo. De hecho, “pensar" (“Denken”), siendo para Heidegger el pensamiento orientado del ser, puede considerarse una manera de "acercarnos en la distancia" (Casey 271). Desde ahora, estar en una "región" significa igualmente "movernos en cierta cercanía" "15. Hay que hablar asimismo de la idea de ansiedad (“Angst”), en Heidegger, categoría ontológica que antecede al comportamiento, la que presenta el mundo como un abismo de posibilidades, algo que "Dasein" evade sistemáticamente porque le amenaza. Lo que nos plantea una relación entre ansiedad y espacio. La angustia (“Angst”) surge cuando "Dasein" (“Ser ahí”) se enfrenta a la nada existencial (El ser 208).

Entendamos que Heidegger abre así nuevas posibilidades espaciales al ser, en el sentido en que por primera vez el espacio puede delimitar, amenazar, trascender al ser: "Con la espacialidad de Dasein, el análisis existencial-temporal parece llegar al límite" (Casey 256) — concluye. Para el filósofo temporocentrista, el espacio no puede ser concebido si no vamos al mundo, o sea, que el espacio no es solamente mental. De ahí que Heidegger anuncie: “La constitución de Dasein se hace ontológicamente posible

\footnotetext{
${ }^{15}$ Es aquí que Heidegger apunta al hecho de la tecnología, que para los años 50 ha abolido las distancias, de modo que "una corta distancia ya no significa en sí misma cercanía, ni una gran distancia algo remoto" (Casey 272). Entonces, si para Heidegger la tecnología ha abolido distancia y cercanía, ¿puede entonces sugerirse un paralelo entre "tecnología" y "sitio"? Anotemos que para el Heidegger tardío, "lugar" termina siendo una escena para el encuentro, para el "cara a cara". Luego "lugar" es "eso-que-regionaliza", a ese ser cuya mundanidad es una estructura a priori (Heidegger, El ser 65-75).
} 
sobre la base de la temporalidad" (Casey 257) — que es la relación temporal-espacial que nos interesa explorar.

Maurice Merleau-Ponty (1908-61) reelabora la dirección del "Lebenswelt" husserleano. Para él la existencia espacial es la condición primaria de toda percepción viviente. Merleau-Ponty se pregunta cómo podemos hablar de espacio sin relación a un cuerpo -siendo este el centro de la orientación en el espacio: “[...] lejos de ser ese ser para mí no más que un fragmento del espacio, debía decirse que no habría espacio en general si no tuviera yo un cuerpo" (102). Nos dice que los seres vivientes poseemos una “intencionalidad corporal" que establece y produce el espacio -que no debe confundirse con la intencionalidad de la mente, conectándose de cierto modo con la "cenestesia" corporal que abordará Husserl. Pero Merleau-Ponty agrega que la intencionalidad corporal (no ya mental), es gracias a la cual podemos sentir el cuerpo en el mundo. Es decir, el origen del espacio radica en la intencionalidad corporal (pre-objetiva, digamos instintiva) ${ }^{16}$.

Detengámonos en la distinción de "lugar" que establece el filósofo, donde "lugar" es ahora una sección más acotada, más específica, del espacio. No se trata simplemente de una localidad, sino que tiene una dimensión virtual ${ }^{17}$. De modo que para los propósitos

\footnotetext{
${ }^{16}$ Casey anota que Merleau-Ponty toma prestado el término de Husserl "intencionalidad operativa" e introduce "intencionalidad original", siendo las dos expresiones del mismo fenómeno: "intencionalidad corporal". Esta intencionalidad corporal del filósofo es una intencionalidad operativa del cuerpo; por ejemplo, no siempre estamos conscientes de nuestras actividades físicas como espantar una mosca, pestañear o caminar. Visto así, estas actividades las realizamos de manera corporal y no mental -no requieren de una intencionalidad mental. Casey establece una humorosa contrapartida: al dictamen de Galileo “iSe mueve!”, y la subsiguiente premisa de Merleau-Ponty, "Me muevo”. Ver cómo Casey aborda la filosofía del espacio de Merleau-Ponty, el Capítulo 10, sección IV (Casey 228-42).

${ }^{17}$ Casey resume el concepto de "lugar" en Fenomenología de la percepción (1945) de Merleau-Ponty de la siguiente manera: "Hablamos de 'lugar' precisamente porque no se trata de algo meramente posicional con bordes indeterminados, como fenómeno ambiguo, si ‘ambiguo' significa el cuerpo vivido en su experiencia
} 
de esta investigación cuando hablemos de "lugar", será otra manera de hablar del “espacio". Otra distinción que utilizaremos será "sitio" (como ya hemos referido) -a partir de lo trazado por Casey, derivado del concepto de panopticón de Bentham. "Sitio" en este sentido será el lugar vigilado ${ }^{18}$.

Merleau-Ponty establece otra distinción interesante entre lo que llama el "espacio espacializante" (l'espace spatialisant), que es un espacio abierto, expansivo (la ciudad, por ejemplo), y el “espacio espacializado” (l'espace spatialisé), que es el espacio cerrado, fijo (una habitación, un bar, una calle específica; las direcciones son siempre "espacio espacializado"). Además, reiteremos cómo Merleau-Ponty otorga al cuerpo su determinación espacial a partir del movimiento del mismo:

Lo que cuenta para la orientación dentro de la realidad que me rodea consiste no solo en mi cuerpo, que lo es claramente, sino ese sistema de posibles acciones que produce un cuerpo virtual con un lugar fenoménico, definido por su tarea y situación. Es decir, mi cuerpo está donde quiera que haya algo que hacer. (Casey 232)

Lo importante de destacar aquí es que los niveles más profundos de subjetividad son en sí "lugar"; considerando que el sujeto-cuerpo es pre-personal y anónimo (Véase el Capítulo 3 de Casey, dedicado a Merleau-Ponty). Escribe que hay "otro sujeto por debajo

con lo conocido. De la misma manera que decimos del cuerpo que 'no está donde está ni es lo que es', de la misma manera debemos permitir que 'lugar' no esté donde está ni sea lo que es: solo la localidad del sitio puede determinar estas cosas. Por lo tanto 'lugar' no es el contenido definitivo de una representación. Esa manera equivocada de ver las cosas refleja el 'prejuicio del mundo objetivo' que el cuerpo viviente se revela en su movimiento hacia las cosas. Como no es el contenido de una representación definitiva, sea idea o imagen, 'lugar' no tiene carácter determinado" (Casey 231-32). También, para comprender el aporte del Merleau-Ponty a la historia del espacio, véase en el capítulo 3 de Fenomenología de la percepción, donde el filósofo establece que el cuerpo es frontera espacial, es decir, punto de referencia en el espacio.

${ }^{18}$ Ésta definición de "sitio" la retomaremos en el Capítulo III de este estudio, dedicado al análisis de la novela Todos se van (2006), de Wendy Guerra. 
de mí, para quien el mundo existe antes de lo que soy, y que marca mi lugar (en el mundo)" (241). Entendemos que se trata de una relación cuerpo-espacio pre-personal virtual -capaz de producir un efecto aunque de momento no lo haga ${ }^{19}$.

\section{La poética del espacio de Gaston Bachelard y el espacio ontológico.}

El filósofo francés Gaston Bachelard (1884-1962) nos ofrece otro ángulo del espacio visto a través del lugar como imagen poética. No perdamos de vista que Bachelard es un filósofo de la ciencia que se propone una investigación fenomenológica. Por tanto su método será cuidadoso, detallado. Escribe: "Buscamos una determinación fenomenológica de las imágenes", explicando que si la imagen puede verse como una especie de fenómeno eflorescente, entonces el lugar donde ésta ocurre debe reflejarse o reverberar con ella. "Eflorescencia", sinónimo de la imagen poética en Bachelard, reviste un aspecto poético, pero su origen es psicológico. De acuerdo a Casey, se trata de una especie de metáfora que recuerda la idea de receptáculo platónico en el Timeo: “Es como si la superficie psíquica proyectara la imagen que recibe [...] debe fulgurar con ella junto a su presencia momentánea" (287).

Lo importante para nuestro estudio radica precisamente en comprender en qué consiste ésta proyección. Para Bachelard, ese contenido poético de la conciencia consiste en una cierta "localidad". En este caso se trata de un contenido que puede ser cognitivo, emotivo, lingüístico o imaginario. La fenomenología por lo tanto investiga éste contenido, al que Bachelard expresa como un cierto lugar de la psiquis (PDE 14-15).

\footnotetext{
19 Para el diccionario de la RAE (Real Academia Española de la Lengua), el vocablo virtual que traemos a colación tiene dos acepciones que nos interesan: 1. Que tiene virtud para producir un efecto, aunque no lo produce de presente, frecuentemente en oosición a efectivo o real. 2. adj. Implícito, tácito.
} 
Imaginemos al "soñador despierto", atrapado en las ensoñaciones (reverie) de las imágenes poéticas. Bachelard acumula evidencia de lo que califica como "conciencia soñadora" ${ }^{20} \mathrm{del}$ poeta/escritor, siendo ésta ensoñación o imágenes las semillas de la creación de un universo que trasciende la ensoñación del poeta/escritor, creando espacios mentales al lector. Bachelard se concentra en la imagen pura, "absoluta" cuando dice:

Tales imágenes deben por lo menos tomarse en su ser de realidad de expresión. Toman todo su ser de la expresión poética. Se disminuiría su ser si se quisiera referirlas a una realidad, incluso a una realidad psicológica. Van más allá de la psicología. No corresponden a ningún impulso psicológico fuera de la pura necesidad de expresar, en una pausa del ser, todo lo que la naturaleza, no puede hablar, y sin embargo, escuchamos. (PDE 215)

¿Son reales estas imágenes? Bachelard responde: "Es superfluo que tales imágenes sean verdaderas. Lo son. Tienen lo absoluto de la imagen. Han franqueado el límite que separa la sublimación condicionada de la sublimación absoluta" (Bachelard, PDE 215). Para Bachelard lo real incluye la conciencia y sus contenidos. Es decir, Gerard de Nerval, el poeta y el Arco de Triunfo en París son tan reales como "el firmamento de vidrio azul", "la sombra que me huye" o "el discurso de las estrellas". 21

\footnotetext{
${ }^{20}$ Es la "conciencia soñadora" a la que Bachelard dedica La poética de la ensoñación (1960) que aquí referimos como POR (en inglés The Poetics of Reverie). Consúltese además el análisis que Bachelard somete a la imagen poética, en relación al espacio, en La poética del espacio (1958) que aquí referimos como PDE.

${ }^{21}$ En The Poetics of Reverie (1960), Bachelard se da a la tarea de documentar decenas y decenas de imágenes producidas por novelistas, poetas, sicólogos, críticos, etc. Los tres ejemplos arriba pertenecen al poeta chileno Vicente Huidobro, el trotskista católico Charles Plisnier y al poeta vanguardista belga Edmond Vandercammen. (Bachelard, POR 104,109).
} 
Estas imágenes moran en un espacio poético fenomenológico: "la fenomenología nos da la posibilidad psíquica de la imagen" (PDE 258). Analizando cómo los poetas/escritores crean a través de la imagen poética, Bachelard explica que la proyección a que nos referimos es "anterior". Aquí anterior indica que la imagen poética se logra puesto que ésta ya tiene su espacio. Para el fenomenólogo este espacio es ideacional: es creado por el poeta, espacio íntimo que se experimenta en el presente (así como otros espacios biográficos que hemos experimentado en el pasado), más la amplitud del mundo $^{22}$. Es que para Bachelard el ser mora en las dimensiones del ensueño poético o reverie, es decir, en la intencionalidad del ser también determina una espacialidad.

Consideramos que la exploración espacial de Bachelard se aviene al lenguaje literario. De modo para los propósitos de este estudio, nos apoyaremos marcadamente en su topofilia. Precisamente, porque se trata de un filósofo de rigor científico, resulta más metódico el punto de mira, si nos asegura que la conciencia se proyecta más allá de su realidad física, en la espacialidad de la imagen poética. Este tipo de proyección espacial fenomenológica es a lo que llamamos espacio ontológico.

\section{Samuel Todes y la sinlugaridad}

También en el siglo XX encontramos otras maneras de explicar el espacio.

Elaborando su tesis a partir de la investigación fenomenológica de Merleau-Ponty,

\footnotetext{
${ }^{22}$ En el capítulo titulado "La inmensidad íntima", Bachelard justifica estos espacios mentales proyectivos del ser, trayendo una cita del poeta Rainer Maria Rilke: “... esta soledad limitada, que hace cada día una vida, esta comunión con el universo, el espacio en una palabra, el espacio invisible que el hombre puede, sin embargo, habitar y que lo rodea de innumerables presencias" (Bachelard, PDE 241). Además: "A cada sustancia su existencia. A cada materia la conquista de su espacio, su poder de expansión allende a las superficies, por las cuales un geómetra quisiera definirlas. [...] ¡Qué concreta es esta coexistencia de las cosas en un espacio que nosotros duplicamos por la conciencia de nuestra existencia! [...] Cada objeto investido de espacio íntimo se convierte, en este coexistencialismo, en el centro de todo espacio. Para cada objeto lo lejano es lo presente, el horizonte tiene tanta existencia como el centro" (Bachelard, PDE 241).
} 
Samuel Todes (1927-94) contrapone su estudio al de filósofos racionalistas como Descartes y Newton, para los cuales la mente es la herramienta descollante en el análisis de la experiencia y el conocimiento. Para Todes el conocimiento es físico, y es determinado por la experiencia corporal. El llamado "campo espacio-temporal" todeseano viene a ser la experiencia del espacio físico distendida en el tiempo. ${ }^{23}$

De hecho, por momentos, Todes le da tanta vigencia al cuerpo que parece caer en una especie de antropofilia, como ilustra el fragmento que sigue:

El mundo conocido que exploro es el mundo del cuerpo humano, así como esos elementos que acusan una afinidad con el cuerpo. Para algo mostrarse debe serle funcional al cuerpo humano: El mundo existe para permitir dicha función. Lo que no puede ser función del cuerpo humano debe estar fuera del mundo y por tanto no puede ni ser ni mostrarse como tal. (Todes 42)

Todes nos habla de campos de experiencia y de vida, y nos dice que la experiencia espacio-temporal es "aparente", pero que está supeditada al cuerpo físico:

Debemos comprender que ese aparente campo espacio-temporal es un campo de vida. Es el campo de nuestras necesidades y persiste mientras esas necesidades son satisfechas por lo que aparece en dichos campos. $E l$ campo de nuestra experiencia persiste mientras nuestra experiencia en él sea posible. (Todes 50-51).

\footnotetext{
${ }^{23}$ Véase Body and World (2001), de Samuel Todes. Aunque se publicara en 2001, el libro que data de 1963, basándose en la tesis doctoral de Todes. Harvard lo había publicado en 1990 entre una serie de ensayos filosóficos.
} 
Dice que tenemos una percepción "subjetiva" y "sentida" de la experiencia, pero que nuestra percepción no cambia la experiencia del mundo. De modo que la respuesta a un objeto anticipado es el punto de encuentro entre el sujeto y el objeto: "En mi respuesta (al objeto) satisfago mis necesidades” (66). Pero, ¿qué sucede cuando no hallo o no está tal objeto?

Todes afirma que nuestras insatisfacciones nos hacen sentir un "vacío de lo no ocupable", o sentir el mundo como vacío. Por ejemplo, el dolor emocional y físico, tiene el mismo efecto que cualquier objeto en relación al cuerpo, pudiendo limitar nuestra capacidad de responder y sentir el cuerpo en su circunstancia espacial (Todes 57-59).

Para concluir detengámonos en lo que Todes llama "vacío de sinlugaridad", que de algún modo se conecta al "Angst" que ocupaba a Heidegger. Todes explica que el "vacío de impermanencia" (que se crea en el movimiento y traslado dentro del espaciotemporal de la vida) anticipa el "vacío de sinlugaridad". Valga la siguiente aclaración: explicando este vacío espacio-temporal, Todes nos remite al término en inglés, “emptiness of placelessness". Placeless es sin lugar; ness es la propiedad del sin lugar. Entonces "placelessness" debe traducirse como sinlugaridad (no se confunda con singularidad): "Esta sinlugaridad más allá del horizonte de un lugar determinado es inagotable, aunque su área interior -de lugares determinados—pueda expandirse sin límite. Esto es el vacio de la sinlugaridad" (Todes 57) (la primera itálica es nuestra, la segunda del autor). Éste vacío, apuntamos, aplica a la condición de exiliado. 


\section{CAPÍTULO II}

\section{LA NINFA INCONSTANTE: EL ESPACIO ONTOLÓGICO COMO CINTA FÍLMICA ${ }^{24}$ DE LA MEMORIA ABOCADA EN LA CIUDAD}

La ninfa inconstante (2008), novela póstuma de Guillermo Cabrera Infante, debe mucho al cine, debido al formato de flash-back revisitado, cual pastiche retraído de la memoria. A Cabrera Infante, Premio Cervantes de las Letras 1997, escritor, crítico de cine y consumado cinéfilo, le gustaba visitar Miami, sobre todo en época de Festival de Cine —nos dijo Miriam Gómez, su viuda y albacea, durante su comparecencia en la Feria Internacional del Libro de Miami de 2008, para presentar la primera novela póstuma que nos ocupa. Aquí conoció a muchos que después se hicieron sus amigos. Aquí se reunía con algunos de ellos: René Jordán, Néstor Almendros, y en los talleres literarios del festival encuentros con Manuel Puig, Sam Fuller, etc. Desde aquí CI apadrinó la carrera en ciernes de Quentin Tarantino, Robert Rodríguez, Abbas Kiorastami y Pedro Almodóvar (apodado "Almodólar" por el mismo Guillermo-Caín) —éstos dos últimos entraron al mercado americano a través del festival.

Del anecdotario íntimo MG dijo: "Él me dio instrucciones para todo; guardaba en dos carpetas blancas preciosas, que yo había comprado (soy supersticiosa), Cuerpos (como 500 páginas) y Ninfa — que salió de Cuerpos" 25 . MG anticipó que Cuerpos "va a

\footnotetext{
${ }^{24}$ Écfrasis, lo usamos aquí como mecanismo por el cual la novela (y el discurrir de la memoria en la novela), es presentada como cine.

${ }^{25}$ Cuerpos divinos (2010), publicado dos años después que LNI y cinco años después de la muerte de CI, es un libro de memorias noveladas. Lo referido por Miriam Gómez, como veremos luego, queda corroborado en LNI. Dice el narrador de LNI refiriéndose a Estela - la protagonista: "No sólo en la memoria (no he dejado de recordarla nunca) sino en mis memorias. Ella es cuerpo divino, pero también un fantasma que ronda mis recuerdos" (LNI 218). El señalamiento es nuestro. El espejismo de la amante púber, basamento de LNI, lo hemos hallado también en la viñeta titulada "¿Fue Eugenia de Montijo una noble Lolita para el plebeyo Humbert Beyle?", incluida en Exorcismos de estilo (1976) de CI.
} 
ser el mejor libro de Guillermo". Alguien del público le recordó a la viuda que CI dijo alguna vez al periodista Daniel Morcate: "Yo contaré cómo es que Miriam es la que escribe mis libros", e interrogada sobre ello, refirió complacida cómo eliminó 100 páginas a La Habana para un infante difunto "porque eran de insultos inadmisibles contra su ex mujer".

Citando a su difunto esposo dijo: "Quiero que (LNI y Cuerpos) tengan lo que tiene la memoria, que bota lo que no quiere; lo que no quiere viene y va, viene y va”. MG narró entonces cómo después de la muerte de CI, y cumpliendo su encargo, releyó incontables veces los textos póstumos que debía editar para armar La ninfa, desvelada, aprendiéndose de memoria algunos fragmentos, "adivinando" palabras ilegibles. Hasta que resolvió hacerlo como montadora de cine (como le hubiera gustado a él): "Monté las escenas. Para ese entonces encontré el prólogo, que me ayudó: Vi el libro”.

La ninfa inconstante (2008) recrea la atmósfera de finales de los años 50: exactamente el verano de 1957. Viene a cubrir el hueco cronológico entre La Habana para un Infante difunto (1979) y Tres tristes tigres (1964). No es una obra maestra, puede argüirse que no pesa demasiado dentro del legado del autor, pero ahí están su ardid y maestría de estilo. La historia es banal como la protagonista; aunque le sirve a CI para ejercitar su memoria topográfica, sus juegos sintácticos y semánticos, el discurrir del referencial cubano-cinéfilo-hollywoodense-bolerístico-habanero. Es un libro joven, fresco, cuyo tema central — tal vez eje de la novela — es la síntesis del tiempo en un

En una entrevista concedida a Rosa M. Pereda, recogida en la monografía Cabrera Infante (1979), CI explica que Cuerpos — de donde sale LNI, recoge una serie de narraciones sobre su relación con diferentes mujeres, "casi siempre muchachas" (Pereda, Guillermo 140-41). Una de estas "muchachas" en Cuerpos es la ninfa que protagoniza la novela que nos ocupa, con el nombre de Elena. 
ahora perpetuo, el conjeturar del ser atrapado en la memoria de una ciudad, el pasado siendo presente en los momentos únicos, reviviéndose en los fogonazos del recuerdo.

Ahí gravita una historia semiautobiográfica trivial, de novela rosa — con pespuntes de novela negra o film noir (se traman dos asesinatos que no llegan a concretarse: el supuesto asesinato de la madrastra de Estela, que no queda resuelto aspecto suspenso o inacabado del relato, y el deseo y planeamiento del asesinato de Estela por parte del narrador/protagonista). Un joven periodista casado, enajenado en sus trabalenguas eruditos, erotizado por la musa arquetipo de la Lolita tropical, "ella se veía como una mujer muy joven que se sentía muy vieja” (30), repasa sentimentalizado la ciudad intocable: "La Habana parece — aparece— indestructible en el recuerdo: eso la hace inmortal" (131). Destaca el gusto de recordar—cual lente de cámara—recuperar ${ }^{26}$ con precisión matemática, unas calles, unos recodos citadinos, la luna sobre el trópico. Recuerda el piano bar a oscuras como black hole empotrado en la luz del mediodía isleño que late en el pasado: "El pasado es un fantasma [...] El pasado es esa tierra inmóvil a la que nos acercamos" (17-18). Evoca el deseo ardiente por la amante púber y perversa, y dentro de la atmósfera existencialista que recorre la novela, el cinismo risueño ante el paso del tiempo y ante la muerte que barrerá con todo: "Ella murió. ¿Se suicidó? No, murió de la muerte más innatural: muerte natural. La mató en todo caso el tiempo" (20).

\footnotetext{
${ }^{26}$ Es una apreciación nuestra, como veremos, justificada, que las novelas más topográficas de CI, las escribe después de su colapso nervioso (volveremos sobre este asunto más tarde). No obstante, en la monografía de Rosa M. Pereda, el propio CI ofrece un indicio que hemos explorado (dice cuando ofrece su cronología en tercera persona): "1974 Luchando con la presión psíquica, presionado por la depresión, termina Vista, que se publica ese mismo año: su primer libro desde que TTT fue editado en 1967. Comprueba que su relación con la escritura ha cambiado, y aunque antes ha dejado que las palabras lleguen al delirio (proceso que culminó en la traducción de Three Trapped Tigers), ahora sabe que ellas pueden también llevar al delirium tremens verbal -y se hace cauto- (Pereda, Guillermo 254) (itálica nuestra).
} 
¿Puede esperarse algo más de una novela? Sospechemos de la aspereza del tema y la hechura díscola, cuando el narrador adelanta que no se propuso más que "literatura dura [...] Esa que está manejada por dioses menores" (239) -de hecho Estelita, la protagonista de esta historia, es un ninfa, o deidad menor (valoremos la doble acepción del adjetivo: Estelita es también menor de edad).

Sean anécdota y pregunta puntos de partida para abordar LNI desde el prisma de la ontología. En el juego metaficticio con el lector, sujeta a un análisis exhaustivo, la obra seguirá abriéndose en significado y sentido ${ }^{27}$ : "Podría escribir mentiras, ya lo sé, pero la verdad es suficiente invención" (20).

\section{Análisis}

Quisiéramos con nuestra investigación salirnos del abordaje trillado a una obra que ha sido frecuentemente estudiada. Por ello hemos escogido una novela póstuma, sobre la que el autor no tuvo todo el control final de la edición y que además, tal vez debido a ello, destila vulnerabilidades, cansancio de formas, azar, extravíos en relación con el resto de su obra. Deseando una mirada que estrene una obra. No obstante, hemos de tener en cuenta lo que Ernesto Gil López resume como notas característica de la obra de Cabrera Infante:

1ra.- Un afán continuo por recuperar literariamente del recuerdo de La Habana perdida. 2da.- Una constante obsesión por el leguaje, tanto en su faceta lúdica como experimental. 3ra.- Una marcada afición

\footnotetext{
${ }^{27}$ En la comparecencia en la Feria Internacional del Libro de Miami 2008, MG también dijo que la novela que nos ocupa comenzó a escribirse en 1962, siendo un folio dentro de Cuerpos divinos, donde CI acumulaba material literario (en ese momento Cuerpos aún no se había publicado, sino hasta dos años más tarde). Dijo que dentro de este folio CI fue acumulando material durante años.
} 
cinematográfica, que enriquece su obra con citas y técnicas de este contexto. 4ta.- Y una innegable capacidad para el humor, que invita a realizar la lectura de sus obras en esta actitud. (55)

Se hace necesario además, tener en cuenta dos aspectos temáticos raigales en la obra, y que Gil López pasa por alto, apuntándolos Rosa M. Pereda como dos temas omnipresentes: el amor y la música ${ }^{28}$.

Procuramos abordar ciertos caracteres ya estudiados, pero bajo otra óptica. Por ejemplo, el componente fílmico, tan reconocible en CI, visto bajo el ángulo fenomenológico bachelardeano, donde el reverie sea la novela visual de la mente. De este modo LNI puede verse como imagen fílmica de la memoria. En ese sentido Henri Bergson, nos puede ayudar a comprender la analogía entre el acto de recordar y el cine. La noción de la durée bergsoneana nos acerca a una exploración de la memoria en su extensión, duración y permanencia.

También, lo haremos trayendo al caso la noción del "claro del bosque" de Heidegger, vista asimismo como la verdad del arte. Tanto "claro en el bosque" como el análisis ontológico de Bachelard, explicarán LNI como una proyección del ser en un espacio, ahora acotado, espacio que aunque relativamente abierto, es íntimo, de acuerdo a la tesis de Merleau-Ponty de "espacio espacializado". Como se verá, este espacio espacializado en LNI es la ciudad de La Habana —reductos de ésta. Deseamos diferenciar e identificar esos aspectos espaciales, particulares a LNI, que de acuerdo a su

\footnotetext{
${ }^{28}$ Rosa M. Pereda, escribió la primera monografía sobre CI: Guillermo Cabrera Infante (Madrid: EDAF, 1979), más tarde fue la editora de Mi música extremada (Madrid: Espasa Calpe, 1996). Pereda es consulta de rigor al aproximarnos a la obra de CI, porque además le unía una amistad con él y con MG. En la antología Mi música extremada, Pereda selecciona textos del autor asiéndose a dos temas que considera fundamentales en la obra: amor y música (véase la página 33 para la justificación).
} 
composición, ocurrencia y desarrollo hemos llamado modalidades. Llamaremos submodalidad, a ese aspecto proyectivo que presente características propias de una modalidad, pero apunte a cierta especificidad que merezca especial atención. Además traeremos tópicos convenientes a estas modalidades y submodalidades. Trataremos de responder las siguientes preguntas: ¿Cómo se manifiesta cada modalidad, submodalidad y tema al caso? ¿Cómo se desarrolla y qué determina cada modalidad?

\section{La nada del ser "G"}

Primeramente, LNI se desarrolla en el verano de1957, un año realmente marcado por una Habana que arde. El ataque al Palacio Presidencial y la toma de Radio Reloj habían dejado una estela de sangre ${ }^{29}$. "El año 1957 comenzó con una alborada de sangre y muerte" (431) —así comienza el capítulo VI del Tomo III titulado Historiología cubana (1974), de José Duarte Oropesa. Abre el año con una bomba que explota en el cabaret Tropicana arrancándole un brazo a una joven, "hecho que se le imputó al líder fidelista Javier Pazos, y que sirvió al gobierno de caudal propagandístico contrario a la insurrección" (431).

A continuación repasemos los más importantes acontecimientos de lo que Duarte Oropesa llama "un terrorismo y violencia que aprisionaron a la ciudadanía en sus garras" (431), de lo que va desde enero de ése año a julio — que es cuando el protagonista de LNI conoce a Estelita. El 17 de enero: ataque al cuartel de La Plata en la costa sur por las fuerzas de Castro. Entre febrero y marzo: En Santiago de Cuba coinciden el asesinato del joven de 15 años William Soler y el ahorcamiento de Alfredo Reyes Rodríguez lo que

\footnotetext{
${ }^{29}$ Para más información véase Historiología cubana: Desde 1944-1959. Tomo III (1974), de José Duarte Oropesa, páginas 431-51.
} 
motivó una manifestación de más de mil damas por las principales calles con el lema "Cesen los atentados a nuestros hijos". El 17 de febrero: Herbert Mathews publica una entrevista con Fidel Castro, desde la Sierra Maestra en el New York Times, dándole a la insurrección gran visibilidad. Aumentan las actividades del foco guerrillero en la Sierra Maestra y la coordinación con células en Santiago de Cuba con Frank País y René Rodríguez en La Habana (435). El 13 de marzo: ataque al Palacio Presidencial, acción casi suicida del Directorio Revolucionario y que casi logra su objetivo de ajusticiar al presidente Fulgencio Batista, quien tuvo que escapar por una puerta secreta. Entre marzo y abril: Hay por demás un ángulo de politiquería que denota la separación entre la clase poderosa y "las fuerzas cívicas del país que no podían ponerse de acuerdo ante la nueva problemática que planteaban los movimientos insurreccionales del 26 de julio de Castro y el Directorio Revolucionario" (441-42). Dice Duarte Oropesa:

Ante el incremento de la violencia gubernamental e insurreccional que tenía lugar en los primeros días de junio, se celebró una reunión de cinco de los partidos oposicionistas en la que se lanza un manifiesto pidiendo “que la solución al problema cubano está en las urnas, no en la lucha armada”. (443)

Luego Batista pone a disposición de la prensa un avión con periodistas para que visiten la Sierra Maestra. En una conferencia de prensa televisada a todo el país, "el coronel Pedro Barreras negó enfáticamente que Fidel Castro estuviera en la Sierra Maestra como había sido proclamado en la entrevista de Herbert Mathews en el New York Times" (449-50). El 28 de mayo: Castro responde a la conferencia de prensa televisada al país con el ataque al puesto militar "El Uvero", donde tenía infiltrados dos 
empresarios, los hermanos Babún, que le informaron a Castro de los movimientos de los militares. El ataque al Uvero trajo como consecuencia una masacre en la que perdieron la vida 4 jóvenes fidelistas. El asesinato fue condenado por las organizaciones cívicas orientales (451). El 12 de julio Castro agrupa a representantes cívicos respetados nacionalmente como Raúl Chibás y Felipe Pazos en un documento llamado "Manifiesto del Frente Cívico Revolucionario", o "Manifiesto de la Sierra Maestra", que dio a la insurrección aún mayor visibilidad en todo el país.

Lo primero que salta a la vista del lector de LNI es que el lugar en el tiempo está escindido del acontecer. Hemos de enfrentar lo obvio aunque sea un reto: una novela que se desarrolla en un periodo específico de La Habana, en una situación de clandestinidad antibatistiana y gran tensión social — de la que el propio autor era muy consciente y partícipe $^{30}$ — y nada de esto está aquí. Lo que nos lleva a preguntarnos: ¿por qué CI no aborda el contexto sociopolítico en la novela? No tenemos otra alternativa que afrontar esta omisión.

\footnotetext{
${ }^{30}$ Carlos Franqui, quien fuera amigo personal del CI y de su familia, en Cuba, la revolución: ¿Mito o realidad? (2006), da testimonio de que en la casa de la familia Cabrera Infante, en el solar Sarrá de Zulueta 408, capitaneados por Zoila, la madre comunista de Guillermo, se urdían proyectos culturales y sociales como la revista Nueva Generación, la Sociedad Nuestro Tiempo, etc. Es importante señalar que Franqui deja implícito que, a pesar del descontento y el activismo intelectual, el joven Guillermo no se sumó a la lucha clandestina armada contra el gobierno de Batista. (Véanse las páginas 119, 145, 373).

La apreciación de Franqui es comprensible - él era un luchador armado; CI utilizaba otros recursos, aunque sí llegara a pasar armas clandestinas al Directorio Revolucionario (Pereda, Guillermo 244). Así refiere CI su propia versión (en tercera persona): “1956 Tratando de usar la Cinemateca como plataforma política, la mata. El gobierno se incauta del club y finalmente lo deja morir" (Pereda, Guillermo 244).

Precisamente el año 1957, cuyo verano está G enfatuado con Estelita, CI lo describe así: "1957 Ve a varios amigos encarcelados o muertos por la Policía de Batista. Actividades clandestinas. Escribe para la prensa clandestina [...] Interrogado brevemente por el Buró de Represión de Actividades Comunitas acerca de su filiación política 1958 [...] Es repetidamente advertido por sus amigos y enemigos acerca del contenido político de su columna. Una delegación de jóvenes socialistas trata de convertirlo en líder de una protesta autorizada. Su columna es censurada estrechamente. Escribe muchos de los cuentos y todas las viñetas políticas de Así en paz como en la guerra. Prepara la primera reunión entre los comunistas y el Directorio Revolucionario. Pasa armas de contrabando a estos últimos. Prepara un viaje a la Sierra Maestra para él y dos periodistas norteamericanos cuando Batista abdica, el 31 de diciembre" (Pereda, Guillermo 244)
} 
Examinemos las motivaciones del narrador/protagonista "G", para darnos cuenta que la evidencia de este acontecer ha sido manipulada, o no hay evidencia. He aquí una dificultad que encontramos: extraer una tesis de una evidencia omitida. El propio CI en otro momento (1988) le reprocharía a “G” su desvarío; así reclama al fotógrafo Manuel Méndez la versión despoblada que ofrece de La Habana:

¿Pero qué pasaría si alguien viniera y fotografiara Madrid, o Barcelona, o Sevilla $[\ldots]$ y no hubiera nadie en las calles, ni en los rincones, ni ante un portón, o detrás de una reja, ni una mano sobre un llamador vistoso: no se viera a nadie, a nadie? Las ciudades estarían desiertas, porque no hay una sola visión urbana que no incluya a los que hacen las ciudades aparte de sus edificios, sus habitantes [...] Se pensaría en un cataclismo, en la consecuencia de una guerra de bacterias o en bombardeo con bombas limpias. (Cabrera Infante, Mea Cuba 120)

¿No nos hacemos una pregunta similar respecto a la exclusión del acontecer sociopolítico en LNI?

Tampoco podemos ignorar que el personaje "G" está teniendo una relación pederasta donde se da una ambivalencia moral que solo se alude furtivamente también. Por lo tanto queremos trazar un paralelo entre éstas dos omisiones. Estas omisiones a su vez contrastan con la insistencia topográfica (casi neurótica) y el juego retórico con el lenguaje. Para explicarlo, a la manera del film noir que por momentos exuda la novela, tracemos un perfil tentativo de "G".

Quien lee LNI se tropieza con un narrador políticamente y moralmente alienado. Primeramente "G" —que así se presenta a su contrapartida fémina: "Puedes llamarme G" 
o su diminutivo “Gecito" (48)—nos remite a G. Caín, que es el seudónimo con el que CI firmaba sus criticas de cine en los años 50, siendo Caín una contracción de sus apellidos $^{31}$. Vemos que en menos de dos cuartillas, “G” despacha toda una revolución social que estremece la ciudad, y de la que el autor fuera intérprete (en Vista del amanecer en el trópico (1974), por ejemplo), porque en LNI solo se menciona en las páginas 222-23, como veremos más adelante). Por lo que hay en él una actitud de alienación. De ahí que G busca refugio en veleidades existencialistas, en un escape de lo político a lo ontológico, y de la realidad al doblez del ser.

Por otra parte tenemos a $\mathrm{G}$ el pederasta, viviendo un romance con una niña, relatado en detalle, pero incapaz de examinar su propia participación en el asunto desde un punto de vista moral. Salvando las convenciones sexuales de la época, nos queda un personaje truncado, en continuo escape de sí mismo — algo que queda muy claro en el Capítulo I de El ser y la nada $(1943)^{32}$, de Jean-Paul Sartre. ¿Qué evidencia tenemos para nuestra tesis? Los momentos furtivos en que se expresa la mala fe sartreana de G, en el autoengaño, en la negación.

El primer capítulo de El ser y la nada (1943) trata sobre el análisis de la negación; incursionemos entonces en un contrapunto conceptual con G. Podrá apreciarse que estos

${ }^{31}$ El seudónimo G. Caín lo adopta en 1954, escribiendo una columna semanal de cine para la revista Carteles. Pero lo que le lleva a adoptarlo fueron sucesos anteriores. En 1952, el año del segundo golpe de estado de Fulgencio Batista, CI publica un cuento corto en la revista Bohemia. Es acusado de "English profanities", multado y encarcelado por el gobierno de dicho dictador. Se ve forzado a dejar la escuela de periodismo, y no se permite publicar más con su nombre (véase Pereda, Guillermo 243).

${ }^{32} \mathrm{G}$ hace repetidas alusiones a El ser y la nada (1943), de Jean-Paul Sartre, quien fuera figura prominente en la formación del existencialismo francés y, por consiguiente, de las letras francesas inmediatamente después de la post-guerra hasta mediados de los años 70 . De hecho, además de las referencias mencionadas en este estudio, en este momento de la trama y en otros contextos, hallamos alusiones explícitas en el prólogo y en las páginas $98,18,213,220$ — por lo que se impone que prestemos atención especial al tema. 
son aspectos que aunque diluidos, aparecen de manera explícita e implícita en las numerosas referencias en la LNI. De hecho en Cuba, el libro de Sartre fue muy comentado y leído en pequeños círculos de la postguerra (Segunda Guerra Mundial). La editorial Iberoamericana publicó en 1954 la traducción de M. A. Vitasoro en 3 volúmenes, que muy probablemente CI descubrió por aquellos años en la famosa librería La Moderna Poesía, en Centro Habana. Así transpira en G, en conversación con un taxista: “--A la Rampa. —Queda lejos. —Pero es temprano para el ser" (24) (la itálica es nuestra).

Sartre parte del problema de la nada: "La nada no es, la nada se hace" (22), dice ¿Quién crea la nada? El ser. Es decir, el ser que hace que la nada arribe al mundo es "ese para el cual la nada ya se presenta como un problema" (22). Luego, ser es saberse lidiando con una especie de "no-ser" (llamémoslo finitud o vértigo del libre albedrío). Tal parece que al lidiar con esa nada, el ser se encuentra cara a cara con su propia libertad. Su capacidad de tomar partido: "No hay diferencia entre ser y ser-libre" (25), dice Sartre. Es decir, la nada enfrenta, emplaza al ser, con una situación conflictiva consigo mismo. CI/G parece darle la razón al filósofo cuando afirma: "El amor no lo conquista todo. El amor no conquista nada. Aún más, la nada lo conquista todo. La nada es omnipotente" (220). La nada sartreana filtra el centro mismo de la experiencia amorosa de G, en un juego semántico recurrente — como vemos en la siguiente conversación con Estela: “¿Por qué estás tan feliz esta noche? — ¿Por qué el ser y no más bien la nada?” (198) (la itálica es nuestra).

De acuerdo al filósofo francés, la dicotomía ser/nada nos lleva a la angustia, pues el libre albedrío representa un límite a la libertad, que describe como "el reconocimiento 
de la posibilidad de mis posibilidades" (35), lo que de otra manera pareciera como un vértigo desenfrenado de opciones que se abren delante del ser. Dice Sartre: "La libertad que se revela en mi angustia se caracteriza por esa nada que se insinúa entre motivación y acción" (34). El ser entonces trata de huir de la angustia a través de maquinaciones, planes que le conducen a lo que aparenta una forma de necesidad o predeterminación, incluso aquello que llamamos la voluntad divina. Así se constata en LNI, cuando G improvisa una huida sin rumbo con su amante púber: "La nuestra fue una fuga vacui. Huíamos y no sabíamos de qué huíamos" (132). Sartreanamente, la libertad del ser tropieza siempre con la normatividad social: "Ella no tenía la menor noción del pecado [...] pero para mí, ella era el pecado y ese pecado llevaba ahora mi penitencia" (LNI 146).

Claro está, el ser se arma de una "distracción" para lidiar con su libertad. Ese es el deseo de escapar, que es también una negación, que Sartre denomina mala fe y a cuyo estudio dedica el segundo capítulo de El ser y la nada. Sartre no aborda el asunto de la mala fe desde un ángulo normativo. O sea, todos tenemos mala fe. La mala fe es resultado de la estructura misma del ser, de la negación que llega al corazón mismo del ser, mientras "uno es lo que no es y no es lo que es" (67). Esta aparente contradicción del ser enfrentado al libre albedrío mina LNI: "Ella había sido prisionera pero ahora era libre. Lo que la hacía peligrosa es que era una esclava que había roto las cadenas. Inclusive las mías. Yo había sido un eslabón, ahora lo veo" (279). Precisamente, lo que hace a Estelita "peligrosa" y atractiva al mismo tiempo, es que no encaja en la norma: "Estelita, vine a descubrirlo demasiado tarde para el ser y temprano para mis dioses tutelares, no tenía lo que la gente llama conciencia" (146) (la itálica es nuestra). 
La pareja busca, muy temprano en la mañana, después de la primera noche juntos, e intentar una dramática fuga, dónde desayunar. La búsqueda que los llevará a un establecimiento cerrado - a pesar del letrero anunciando servicio las 24 horascorroborando el absurdo existencial. Es que ellos parecen transcurrir en un tiempo fuera del tiempo: "Era obvio que habíamos llegado a la hora 25 para producir esa inquietud que llamamos mañana" (126). Nótese que "mañana" aquí tiene más de una connotación con matices existencialistas, siendo las horas que van del amanecer hasta antes del mediodía, y el futuro, el porvenir (desde donde se asoma el relator, siempre mostrando las costuras de la novela): "En el pasado vemos el tiempo como si fuera del espacio" (17)—dice.

A pesar del tono lúdico tan presente en el texto, y a propósito de ello, el matiz existencial dulce-amargo recorre la novela de arriba abajo: "La vida, en su mejor momento, es apenas soportable" (175). Plasma así un devenir amargo de la existencia con visos sartreanos:

Tampoco juego yo pero estoy acostumbrado a que en la vida siempre pierdo. Ella no negaba la vida pero la afirmaba. Para mí, la literatura es más importante que la vida. Para ella no había más que indiferencia y aburrimiento. Es decir, vacío, el vacío. Pero ella vivía y yo sólo miraba verla vivir y sufría, al principio. Después, como ahora, sólo sonreía -o me reía dentro de mí. (237)

De hecho, G está profundamente atraído por ese vacío que encarna Estelita, hasta el punto de abandonar a su mujer e irse a vivir con la niña. Parece como si G intuyera que vive en mala fe. Es decir, es capaz de comprender la realidad y sin embargo se miente: "Al revés de las fábulas, cuento este cuento sin la esperanza de una moraleja" (53) - 
declara. Precisamente, Sartre define la mala fe como una forma de mentir donde "el que miente está en completa posesión de la verdad que oculta" (48). El filósofo explica que hay una diferencia entre mentirse a uno mismo y la mentira en general: "La esencia de la mentira radica que el mentiroso está en posesión de la verdad que se esconde" (48). No se miente de lo que no se sabe, ni se miente tampoco si uno realmente se cree una mentirano se miente si está equivocado. El ser no puede mentirse a sí mismo, pues la conciencia es "translúcida [...] si yo tratara de mentirme, mi mentira se derrumbaría delante de mí, pues queda arruinada en las espaldas de mi conciencia” (49).

G no acepta la evidencia, ni en el caso de Estela —que es una menor- ni en el caso de la realidad sociopolítica. Sartre lo explica así: "La mala fe aprehende la evidencia, pero está resignada de antemano a no aceptar esa evidencia, a no dejarse persuadir" (68). Se comprende entonces que la mala fe haga posible toda una serie de comportamientos en G que contrapesen o justifiquen esta lucha interna. Sartre considera como una actitud posible el cinismo o la alienación, pero ninguno funciona. La mala fe es un escape, no solo de la libertad del ser, sino de cualquier aspecto de la vida, básicamente cualquier tipo de mentira. Con todo, la mala fe "no llega jamás a creer lo que quisiera creer, y esa aceptación de no creer lo que cree habla de su mala fe" (70). Por lo tanto, la mala fe aparece en forma de un escape imposible. "Huir de lo que no se puede huir, es decir, huir de lo que es” (70). Sin embargo esto lo hace más deseable.

G plantea el asunto escabroso del estupro varias veces en la novela, pero de manera oblicua, en mala fe. Refiere, por ejemplo, la biografía de John Ruskin, quien se enamorara de una niña de doce años: “esta noche, Ruskin podría entrar en mi pellejo (116). La trasgresión filtra la evidencia de mala fe sartreana: “¿Hay una memoria ética? 
¿O es estética, es decir selectiva?” (18)—se pregunta. Se protege en la palabra frágil de Estela - aun cuando a todas luces la niña no es de confiar. Pero el adulto creerá lo que desea creer cuando propone:

— ¿Podemos ir a una posada? —era una pregunta que no era pregunta.

- Podemos.

— Pero tú eres menor.

— No ahora. Ya cumplí dieciséis.

— ¿Cuándo?

— Esta mañana cuando salí de mi casa, ahora soy ya mayor.

¡Ésa sí era una noticia! Era, en realidad, como una especie de indulto antes de cometer el crimen. (109)

El crimen es sexual. Sin embargo, hacia el final de la novela, como quien carga el fardo de una culpa, cuando recapitula sobre la historia, como de paso, refugiándose en el juego retórico, confiesa al lector "bilingüe": "Stella not yet sixteen", y al lector "monolingüe" que "Estela no tenía dieciséis años todavía" (257). Esta evidencia manejada de manera ambigua y esporádica, puede argumentarse que debilita una novela que tal vez se hubiera beneficiado de ser complemente amoral, y no medianamente insincera.

Aflora entonces la nada irresistible que alude Sartre — que habrá de combatirse con el juego retórico —el arrepentimiento prousteano (que veremos más adelante), el desaliento: "el esteticismo es el último refugio del fracaso de la vida" (256). La atracción es nefasta y propicia, porque en Estelita a veces se mira G como en un espejo: “¿Es una existencialista, calificación que le hubiera hecho reír, si es que reía? O era, lo que es más 
probable, una amoral absoluta" (213). Ella encarna esa imposibilidad del ser en libertad total, desertora prematura del canon:

Era todo subconciencia: una conciencia sumergida que rara vez salía a flote. No es que Estelita me fuera infiel. Era que le era infiel a todo menos a sí misma. Su mayor infidelidad estaba reservada al sentido común. O mejor dicho, a las conveniencias sociales, a las convenciones. $\mathrm{Si}$ insolencia no era una máscara, como pasa con muchas muchachas muy jóvenes. La insolencia de Estelita era de verdad verdad [sic]. (146)

G se angustia ante tamaño desatino; ella lo enfrenta a su propia nadería existencial. Ella lo desarma: "Yo era apenas un esteta. Me había refugiado en literatura" (255). Entonces el ser se presenta nulo, neurótico. La ceguera de G no ve su propia realidad y para compensarlo desarrolla una neurosis topográfica, o se pierde en el juego con el lenguaje — la locura de la verborrea metonímica, paráfrasis, aliteraciones, etc. G se diluye en la formalidad: "nunca sabe uno adónde va a llevarlo el juego" (91) — siendo otra forma de neurosis sintáctica, donde la topografía se convierte en una sintaxis.

De modo que LNI parece debatirse entre dos nadas. Cada una obedece a dos ejes centrales que a su vez determinan dos huidas (o escapes existenciales en mala fe $)^{33}$. La primera huida al no afrontar la realidad sociopolítica; la segunda al no enfrentar su propia realidad moral. Cabe sugerir las siguientes preguntas: ¿Por qué en LNI se elude lo político? ¿Qué clase de ser moral es G? ¿No tiene G acaso la intuición del cambio social

\footnotetext{
${ }^{33}$ Comentando la mala fe, Paul Arthur Schilpp en su libro The Philosophy of Jean-Paul Sartre (1981), comenta que la mala fe "es una distracción en que la conciencia se escapa y se ausenta de sí misma" (75).
} 
y político que se avecina? ¿Le tiene horror a su futuro porque lo sabe? ¿Le tiene horror al pasado?

G recupera la memoria de la ciudad, deslindada de la revolución que la sacude. Que es lo equivalente a estar en medio de la Revolución francesa, paseando por los jardines del Palacio de Versalles, sin mencionar la guillotina. La reticencia topográfica es neurótica porque al otro extremo de lo específico hallamos rotundas omisiones. El ser se anula perdiéndose en la manía topográfica (ordena el mapa amenazado por el desorden emocional), y la nada del ser es la locura - trastorno que, tristemente, no fue ajeno al autor. Nos apoyamos aquí en una idea planteada por Enrico Mario Santí:

Lo heroico es que, a pesar de encontrarse con sus facultades disminuidas por los dieciocho electro-shocks que se le administraron en 1972, Guillermo continuó su obra. Me atrevería a decir que fue precisamente a causa de su condición, luego diagnosticada como trastorno bipolar, que, tal como en un programa de rehabilitación, emprendió dos vastos ejercicios narrativos: uno, de disciplina objetiva, en Vista del amanecer en el trópico, la perturbadora serie de viñetas sobre la violencia histórica en Cuba; y otro, de recuperación de memoria (geográfica y erótica) en $L a$ Habana para un infante difunto ${ }^{34}$.

Raymond D. Souza, en su biografía de CI, Cabrera Infante: Two Islands, Many Words (1996), refiere el temor de MG al tener que decidir sobre si CI recibiera o no

\footnotetext{
${ }^{34}$ Véase "Cabrera Infante: El estilo de la nación”, artículo de Enrico Mario Santí, publicado en la revista digital Letras Libres, en abril de 2005. También, en Infantería (1999), CI comenta a Santí (quien prefiere un enfoque psicoanalítico) la "locura" de 1972, "curada ahora, creo, por la ingestión de lithium o litio", así como "la depresión patológica que me afecta desde entonces" (1092).
} 
tratamientos de electroshock, como recomendaba el médico, porque ella sabía que la escritura de su marido dependía en gran medida de la capacidad de recordar el pasado (119). El capítulo ocho de Souza abunda en un análisis biográfico valioso, pero concluye con una párrafo que banaliza la saga de la locura en CI: "[...] fue simplemente un hombre puesto a prueba más allá de su capacidad de resistir" (122), concluye. Souza evita las asociaciones simbólicas del psicoanálisis, y al hacerlo, se pierde los grises y dobleces, los recovecos de la locura que pueden atisbarse desde un abordaje más arriesgado. Comprensible: cualquier locura es siempre un misterio. Mejor aún, la cordura de CI, que batalla su locura y su desmemoria ayudado por un medicamento (o varios), representa un territorio tenebroso para cualquiera.

Sin embargo, hemos rastreado una entrevista prácticamente desconocida, realizada por Cecilia García Huidobro, en Santiago de Chile, en 1989, donde CI hace una apología del litio (medicamento que probablemente consumió hasta su muerte), de la que referimos un fragmento en la nota al pie de la página ${ }^{35}$. También está la introducción

\footnotetext{
${ }^{35}$ La entrevista de García Huidobro es lo más relevante que hemos encontrado sobre este aspecto biográfico de CI. Referimos aquí un fragmento porque constituye una revelación, dentro de la discreción, comprensible por demás, que existe sobre el tema.

"-Sin embargo, su trabajo con el director Joseph Losey terminó en una casa de reposo.

-En un manicomio, usted es muy fina. Es una sudamericana eufemística. ¡Terminé en un manicomio!

- ¿Y por qué fue una práctica tan difícil?

- Bueno, yo creo que fue una experiencia múltiple. Había muchas cosas actuando sobre mí. Fue exceso de trabajo, pero al mismo tiempo el resultado de muchos problemas personales. El psiquiatra era muy divertido, a cada rato me decía: “¿Y no será la causa que usted dejó su país?” Digo "yo no deje mi país, el país me dejo a mí". Además yo nunca fui más feliz que cuando me di cuenta que ya no podía regresar, que el avión había llegado a un punto sin retorno. "Ah bueno, no sería la muerte de su madre", decía el doctor. “¿En 1972, doctor?”. "Mi madre murió el año sesenta y cinco, ¿no sería un poco retardado el efecto?”. Siempre me hacía este tipo de preguntas, él trataba de conocer las causas y lo que pasa es que hay una verdad que yo descubrí por mí mismo y es que la locura es un efecto sin causa, es como pretender que por algo que tu hayas hecho sufras de cáncer, es realmente un complejo de culpa aplicado a una enfermedad. Lo mismo pasa con la locura, tu estás loco y eso no tiene explicación. Claro que la explicación que le dan ahora es mucho más interesante e inteligente y es que es un problema genético, eso puede ser verdad. Porque yo tuve un abuelo, un abuelo paterno, que se volvió loco y mató a su mujer y se suicidó cuando mi padre tenía dos años. Yo lo vine a saber cuando tenía como veinte años. Mi padre nunca hablaba de éso.
} 
descarnada al libro Trastorno Afectivo Bipolar. La enfermedad de las emociones (2003), donde CI reitera el episodio maniaco obsesivo que lo avasallara de 1972 a 1975 (y sobre cómo bandearse cuando se padece bipolaridad): "Estuve muy loco: ya no me importa contarlo" (25) —ofreciendo detalles especificos de su enfermedad mental: "Siempre una paranoia excesiva me conduce a los más extraviados vericuetos" (28). Tratamos de decir que ciertas dosis de mala fe se escapan de la intencionalidad del autor de LNI, debiéndose al trastorno bipolar y al consumo sostenido de litio.

De cierto modo la mala fe es como un exilio de sí mismo. Podemos decir que CI se exilia en G, y G se exilia en la topografía y la retórica — que son dos maneras de instrumentalizar a Estelita, de "ciudadificarla" (el uso de éste término lo veremos enseguida, en la primera Modalidad analizada). De igual manera que la inicial del seudónimo puede ser una reducción de Guillermo, el preámbulo amoroso que constituye esta historia es una apócope biográfica, un extracto de la historia completa. Si la mala fe es huir de lo factual e inventarse un cuento (para no enfrentar el vacío), ¿cuál es la nada de G? La nada de G es la locura. Desde el punto de vista del espacio sociopolítico de G, puede decirse que LNI no presenta evidencias históricas, sino ausencias y omisiones. De

Puede haber habido un gene que saltó sobre mi padre y me cayó a mí. Porque yo todavía no estoy curado, estoy aliviado, estoy zurcido, pero no renovado.

- ¿A lo mejor no tiene cura?

-Eso es lo que yo me temo. Yo tomo una medicina muy fuerte que se llama litio, es un descubrimiento que hicieron en los años cincuenta, que ha acabado con Freud porque si una pastilla blanca, de una sal, remienda la locura, entonces no hace falta el sofá, no hacen falta confesiones. Aunque Freud fue muy hábil no se metió nunca con la locura, el trataba neurosis pero no psicosis.

— ¿Quizás tomaba litio?

- No, eso vino después. Lo que yo tengo es una personalidad maniaca depresiva. Eso quiere decir que me entusiasmo demasiado y después me deprimo." Véase la página 87. 
ahí que la novela esté repleta de referencias topográficas de una meticulosidad neurótica.

Dicho en términos fílmicos, a LNI le falta metraje ${ }^{36}$.

Lo anterior nos permite sugerir dos ejes alrededor de los cuales gira la novela, no para proponer una estructura, sino a manera tentativa de indagar nadas de G:

Lo político

Realidad socio-política

Región (ciudad)

Represión socio-política

Revolución

Dictadura
Lo moral

Realidad subjetiva en la memoria

Sitio (topografía neurótica)

Represión de la memoria (metraje extraviado)

Seducción

Pederastia

En lo que sigue queremos ampliar nuestro análisis para informar sobre estos reductos espaciales, filtrados por la nostalgia del exiliado.

\section{A. Modalidad "nostalgia-reflexiva"}

En The Future of Nostalgia (2001), Svetlana Boym identifica dos tipos de nostalgias, la "nostalgia restaurativa" y la "nostalgia reflexiva", en un análisis que se centra en la experiencia post-comunista de la Europa del Este. Los términos acuñados por Boym ayudan a entender las proyecciones del ser en los entornos físicos perdidos (téngase en cuenta que las dos novelas estudiadas para esta tesis se escriben, desde el exilio la primera y desde el inxilio la segunda). La primera nostalgia, que consideramos no es relevante aquí, hace énfasis en el "nosotros”, en reconstruir el hogar perdido. El afectado por este tipo de nostalgia no se ve como nostálgico, sino como persiguiendo la verdad histórica, trae símbolos nacionales y teorías conspirativas, pone su atención en "la

\footnotetext{
${ }^{36}$ La historia de Estela que hallamos en LNI, vuelve a referirse en Cuerpos divinos (2010), pero allí la joven se llama Elena y los hechos históricos que acaecieron en 1957 enmarcan la relación. Estelita regresa como Elena, dentro de la crónica autobiográfica. Resulta particularmente curiosa la repetición de la historia (y el doble del personaje Estela), las secuencias completas, pero ahora con otros detalles agregados que de cierta manera completan lo referido en LNI y destacando las ruidosas omisiones que hemos abordado. Véase desde la página 7 a la 147 de Cuerpos divinos.
} 
reconstrucción de los monumentos del pasado" (Boym 41). Boym no ve como positiva esta recapitulación del pasado (lo que en el exilio cubano tradicional —aquél que constituye la primera ola de exiliados - significa rescatar a Fulgencio Batista, restaurar 1959).

La segunda nostalgia se pierde en la ruina, en la pátina del tiempo, presentando una especie de disfrute en lo perdido. Es la "nostalgia reflexiva" que permite volver y disfrutar las contradicciones distantes en el tiempo, que es algo que hace CI desde su exilio en Londres. Para explicar la "nostalgia reflexiva” Boym interpreta a Marcel Proust, argumentando que en el matiz de esta nostalgia se fragua la búsqueda del ser, donde la meta de la odisea es el encuentro con uno mismo:

Para Marcel Proust, rememorar es una aventura impredecible dentro de percepciones sincréticas donde las palabras y las sensaciones táctiles se superponen. Lugar significa abrir mapas mentales y el espacio se vierte en el tiempo. (50)

Para Proust, la memoria de una imagen en particular es un arrepentimiento de la imagen, algo así como el abatimiento por este momento que no puede corregirse. No obstante, en LNI se transparenta que para CI no es relevante que la transcripción de la memoria se traicione, ya sea conscientemente desde la creación literaria, o inconscientemente como lo entendiera Proust ${ }^{37}$ : "Pero lo que recuerdo ahora es lo que quiero recordar" (107).

\footnotetext{
${ }^{37}$ Boym cita al Proust del final de Swann's Way (1913): "La memoria de una imagen en particular no es más el arrepentimiento de un momento en particular; casas, caminos, avenidas son tan fugitivos como los años" (50).
} 
Sobre este punto Boym concluye que lo importante para este tipo de nostalgia es el contrapunto, la fuga a la memoria literaria, y no el regreso al topos real intacto (harto imposible, por demás); G parece coincidir: "Lo que recuerdo es lo escribo. Entre ambas acciones están las omisiones —que son los intersticios, lo que se queda” (19). Ni tan siquiera es relevante el registro íntegro de la memoria (contingente, subjetiva de por sí). G lo sabe, aún se embarca en un regreso factual que se nos antoja acaso imposible, a todas luces subjetivo, siendo la memoria el vehículo desorganizado que, contradictoriamente, aún nos permite, en términos de Boym, describir la fenomenología de la experiencia, a partir de una proyección del ser conjetural ${ }^{38}$ : "Para mí la literatura es más importante que la vida" (237) — dice G.

Boym expresa que la "nostalgia reflexiva" puede sentirse "home sick" y "sick of home at once" (50), lo que puede traducirse como extrañando el hogar y hastiado del hogar a un mismo tiempo. Así vemos cómo G después de un alarde de la "memoria reflexiva, ${ }^{\text {,39 }}$, expandiéndose en la descripción del lugar y el esmerado lujo de detalles, cierra la imagen de la ciudad -presentada como campo de juego:

En el trazado estaba el trazo que me definía: éramos dos piedras en el juego de Go [sic], donde los jugadores se dividen en débiles y fuertes, pero éramos a la vez los jugadores y el juego. Siempre se da ventaja al jugador débil antes comenzar a jugar. Que gane el peor. En ese diagrama,

\footnotetext{
${ }^{38}$ Dice Boym: "Todavía ningún sistema de pensamiento o rama de la ciencia nos provee el cuadro completo de la memoria humana. La interpretación de la memoria puede bien ser una "ciencia conjetural", dicho en un término de Carlo Ginzburg. Solo las memorias falsas pueden ser totalmente recordadas. Desde el arte mnemonic griego a Proust, la memoria siempre ha sido abordada a partir de un trazo, un detalle, una sinécdoque sugestiva" (54).

${ }^{39}$ Para otro ejemplo de alarde de la memoria, entre varios, léase de la página 177 a la 178 de LNI.
} 
que no era un plano azul, a pesar del cielo consentidor, nos encontramos y nos perdemos. Eso se llama, también, destino. (LNI 178)

Notemos el matiz melancólico, donde los protagonistas, él y ella, sellarán un destino lacerante -la proyección de la ciudad terminará doliente, hallando el tipo de nostalgia analizada aquí, especie de placer insano en la proyección del ser. El destino azaroso se abre al espacio ontológico en el tablero virtual. Vemos al ser proyectarse, viajando desde el futuro para recrear un presente del pasado. Imaginamos al autor cual cartógrafo aficionado, inclinado sobre el mapa de La Habana — recorriendo la ciudad desde arriba, cual demiurgo — dueño de su pasado, planteándose los destinos de los protagonistas como fichas en un juego de azar: "La memoria, como ven, también es selectiva. Todos somos hijos de Proust y Celeste Albaret ${ }^{40 »}$ (34) — dice G.

Ni qué hablar del presente en que escribe $\mathrm{CI} / \mathrm{G}$; el topos desfigurado del presente prescinde del escritor exiliado y prohibido en la isla, y éste reclama, por la vía literaria, un espacio usurpado. Por lo que produce una visión parcializada del pasado sin presente, de una realidad que le excluye. Rafael Rojas lo analiza aquí:

¿Qué tan conocida es la literatura exiliada en Cuba? [...] Aunque en las librerías cubanas nunca se ha vendido un libro de Cabrera Infante, muchos ejemplares de Tres Tristes Tigres y La Habana para un Infante difunto han entrado en Cuba y algunos pueden leerse en bibliotecas públicas de la isla. Sin embargo, ese tipo lectura de libros no editados y, por tanto, no vendidos, no presentados y no reseñados en las publicaciones literarias

\footnotetext{
${ }^{40}$ Fue la sirvienta de Marcel Proust, y custodia de su obra.
} 
oficiales, es en todo caso, la lectura marginal de pequeñas minorías. ( $E l$ estante 210)

¿Puede CI saberse atrapado en una topografía de la memoria coloreada por las emociones de las pérdidas, tanto como el borrón de su nombre del catálogo de autores y la exclusión de su obra de los anaqueles en las librerías de la isla ${ }^{41}$ ? En el recaudo detallado de la ciudad (leit motif de toda su obra) atisbamos una búsqueda deliberada por auto-recuperarse allí, recolocarse en el estante vacio que indica Rojas. Pronunciarse bajo el estigma de los escritores "impronunciables", "o pronunciados siempre para las peores calificaciones" (Ponte, Villa Marista 166). Este proceso diacrónico en CI, se anima con elementos de la era pre-revoluciona. Veamos un ejemplo que nos parece análogo, referido por Boym sobre Alemania del Este, después de la caída del muro que dividía a las dos Alemanias:

Frecuentemente, los parámetros colectivos funcionan como pantalla de la memoria, determinando el contexto de la recopilación afectiva del individuo. En el exilio o en la transición histórica, los símbolos del país de origen una significación emocional. Por ejemplo, en Berlín, los alemanes occidentales lanzaron una campaña para eliminar las señales de tráfico de Ampelmann, el simpático caminante del sombrero que fue suplantado por una señal más pragmática de la Alemania oriental. Nadie nunca le prestó

\footnotetext{
${ }^{41}$ Aún después de muerto, CI mantiene una disputa virtual con la dictadura que lo empujara al exilio. Según reporta Antonio José Ponte, apenas el 8 de febrero de 2007, en la decimosexta edición de la Feria del Libro de La Habana celebrada en la siniestra cárcel de la Cabaña, César López, que era el poeta al que se le dedicaba la edición de la feria, mencionó en su discurso de apertura, entre otros nombres de escritores exiliados ya fallecidos como Gastón Baquero, Reinaldo Arenas, Heberto Padilla, etc., el nombre de Guillermo Cabrera Infante. Véase Villa Marista en plata. Arte, política, nuevas tecnologías (2010), página 165.
} 
mucha atención a Ampelmann, pero ahora que desaparecía de las calles se convirtió de la noche a la mañana en el símbolo de toda una nación (Boym 54).

En LNI, la "nostalgia reflexiva" compresa la memoria, al estilo de CI, (con pespuntes de ironía), en la descripciones del pasado como pasado (y del pasado como invención), y en los lugares comunes de los recuerdos memorables del exiliado -arsenal nostálgico que el propio CI ayudó a fomentar. Tanto así que se le reconoce como caso paradigmático. Iván de la Nuez lo corrobora:

[...] es el inventor (tan imitado después) de la literatura de una Habana invariable y "perdida”, como su música o sus placeres, al extremo de que sólo puede existir en tanto él la recuerda y la reconstruye en su escritura. (El mapa 127$)^{42}$

De la Nuez llama a este fenómeno literario "nacionalismo de la memoria", trayendo ejemplos de países de Europa del Este tras la caída del muro de Berlín y el final de la Guerra Fría: “De repente, la Unión Soviética se convierte en la Rusia -Solzhenitsin o Tarkovski_, Yugoslavia en Serbia - Milorad Pàvic_-, Checoslovaquia en Bohemia — Kundera-, y Cuba en La Habana —Cabrera Infante” (El mapa 126).

La tesis de Boym, arroja luz sobre esta dinámica selectiva y compresiva de la experiencia trayendo el ejemplo de un bar en Ljubljana (antigua Yugoslavia, hoy capital de Eslovenia), que visitara 1997. El decorado del local exhibe (hasta hoy día) cajas de

\footnotetext{
${ }^{42}$ En El mapa de sal (2010) Iván de la Nuez cuestiona la percepción del paisaje original a partir de la pérdida. Evoca aquí otra novela cabrerainfanteana: "Su conocida novela La Habana para un infante difunto comienza, precisamente, con la entrada en el cálido espacio de la vagina, que es la ciudad, el útero materno, mediante el cual retroceder hasta la infancia aún más lejos: al origen mismo de una cultura que ya no está en nosotros" (127).
} 
sazón rusa Vegeta (considerada una exquisitez en la otrora Unión Soviética), pósteres de la nave espacial Spútnik llevando los caninos Belka y Stlelka, conjuntamente con una ampliación de la portada de un diario anunciando la muerte de Tito (ex presidente de Yugoslavia), etc. El bar se llama Nostalgija Snack Bar, y evoca la atmósfera de los años 60.

Coincidentemente en Miami (lugar donde se origina nuestra tesis), existe, desde principios de los años 90, un café bar que en un principio ostentaba el nombre Café Nostalgia, habiéndosele sustituido por Hoy como Ayer a partir de un traspaso de propiedad, aún manteniendo el mismo concepto. De sus paredes cuelgan innumerables fotografías de artistas cubanos, collage de ellas, una especie de altar a Benny Moré ("Hoy como ayer" es también el título de un bolero de Benny), y memorabilia de la Cuba de antes del 1959, así como del subsiguiente exilio histórico, que incluye figuras artísticas ya desaparecidas. Pero también, curiosamente seleccionados, hallamos músicos y cantantes "no comprometidos" de la era revolucionaria ${ }^{43}$. A diferencia del bar en Ljubljana, en el bar de Miami (ciudad considerada la "capital del exilio" cubano), queda fuera lo político. Tal vez porque, a diferencia del Nostalgija Snack Bar, aún después de 50 años, lo político en la isla no está resuelto en un cambio social.

Según matiza De la Nuez, Miami es "la primera ciudad del post comunismo cubano" donde se manifiesta "el tipo de filosofía territorial y temporal que persiste en la

\footnotetext{
${ }^{43}$ Son estos artistas que no partieron al exilio. O los que por un grado menor de compromiso con el régimen, continuaron con sus carreras artísticas durante el proceso revolucionario. Algunos nombres son: Albita Rodríguez, Elena y Malena Burke, Mirta Medina, Maggie Carlés (artistas del exilio reciente), Argelia Fragoso (más reciente aún), Farah María (viviendo en Europa desde hace años), etc., así como otros que hicieron sus carreras en la isla, pero sin identificarse abiertamente con el régimen, tales como Los zafiros, Meme Solís, etc. Quedan excluidos muchos de los músicos de la Nueva Trova (movimiento que aunque se iniciara con la canción protesta de corte crítico, posteriormente se moldeara revolucionaria y ayudara a fomentar el proceso revolucionario), y aquellos comprometidos con la revolución cubana.
} 
versión retrógrada de un post comunismo que vuelve a los orígenes precomunistas para establecerse" (El mapa 121-22). Ciertamente, en Miami parte del exilio busca restaurar la época prerrevolucionaria — llamado el exilio histórico: la primera generación de exiliados que llegara inmediatamente después del triunfo revolucionario. Éste grupo encarna el tipo de "nostalgia restaurativa" que acuña Boym. Pero también, coexisten otras corrientes de exiliados "post comunistas" que no vivieron la era precomunista (por lo que no la tienen como referente), cuya nostalgia tiene otros tonos. Parte del exilio cubano - sobre todo el más reciente, que llegara a partir de los años 90 - refleja una "nostalgia reflexiva" que añora aspectos de la era anterior a la caída-del-muro de Berlín, mientras no conocieron un tiempo mejor.

El ensayista Rafael Rojas dice al respecto: "De manera ambivalente, la isla queda comprendida en el derrumbe del socialismo: lo que pasa en Varsovia, Praga y Sofía pasa y no pasa en La Habana" (El estante 84). Pasa, porque en Cuba se vivió la expectativa de una reacción en cadena en los cambios sociales del bloque socialista, que en la isla caribeña, tan lejos, nunca llegó a reflejarse; no pasa, porque el gobierno no permitió ningún tipo de apertura, y el país se cerró en sí mismo. Estos exiliados a los que la decepción les vino más tarde, practican una especie de nostalgia con pinzas. Donde se extrae lo salvable de la experiencia comunista, marcados por un post-socialismo-postcomunismo que les llegó de oídas, y que experimentaron como un recrudecimiento económico y una pericia de relocalización ${ }^{44}$.

\footnotetext{
${ }^{44}$ Rojas cita al filósofo Slavoj Žižek para explicar cierto malestar "provocado por una ontología política sin centro" (88). Véase El estante vacio (2009) páginas 80-90. Volveremos sobre este tema en lo referente a la novela Todos se van (2006) de Wendy Guerra.
} 
De hecho, Hoy como Ayer reúne la memoria selectiva de un poscomunismo retro y un post socialismo selectivo (tras la pérdida del patronato soviético) como claves de éxito, donde las discontinuidades y omisiones de la memoria se entienden. La memoria colectiva lo cuaja sin cuestionarlo: una gran pantalla proyecta constantemente videos musicales de antes del 1959 y de años posteriores, los años 60, 70, 80, 90, etc., siempre eludiendo el elemento perturbador ${ }^{45}$. ¿No es esto lo que hace CI en LNI?, ¿sustraer la relación amorosa del contexto político? Efectivamente, LNI tiene la resonancia de un bolero nostálgico, o, para utilizar un adjetivo más prousteano, de un bolero arrepentido —el protagonista no podrá (y tal vez no desearía hacerlo) rectificar la experiencia: "La narración intenta llenar ese vacío, pero ese vacío es el centro de la narración porque era, ¿quién lo diría?, la propia Estelita” (LNI 14).

En el verano de 1957, los amantes visitan un bar, especie night-club que funciona en pleno día. La escena la abordaremos más adelante, pero anotemos que lo que acontece en el night-club de Miami aún en la segunda década del siglo XXI, aparece aquí como síntoma: Se excluye la carga discordante de lo político, sólo evidenciada como síntoma de la "nostalgia reflexiva" que le adjudicamos ${ }^{46}$. Sin embargo, esta dinámica selectiva, para compensar su falta, presta particular atención al lujo del detalle topográfico. El

\footnotetext{
${ }^{45}$ Boym reconoce lo problemático que puede resultar colocar emblemas del pasado yugoslavo dividido en las paredes del Nostagija Snack Bar (léanse las páginas 51-53).

${ }^{46}$ Por estas fechas CI estaba involucrado en actividades políticas clandestinas para derrocar al presidente Fulgencio Batista, y mantenía una actitud crítica. Ya hemos mencionado que un poco antes había caído preso a raíz de la publicación de un cuento, "Obsceno", en 1952, que los censores del régimen consideraron obsceno - a partir de entonces se le había prohibido publicar con su nombre, optando por el seudónimo de G. Caín. Y es que el país - sobre todo La Habana - se debatía en la violencia política. Pero acentuamos aquí que CI en la novela se abstrae de político. Como contrapunto, veremos en el capítulo dedicado a Todos se van (2006), cómo WG cuestiona lo político y lo ausculta bajo el velo de la censura — esto sucede cuando el bloque socialista se resolvía en cambios, que desencadenarían en la caída del Muro de Berlín. Pero ahí en el umbral de los 90 que enmarca la novela de WG, Cuba ratificó su permanencia revolucionaria y continuidad socialista.
} 
espacio físico se apoya además en la música, en constantes alusiones musicales del cancionero nacional o en referencias directas e indirectas aliteraciones-particularmente del bolero: "La música es la madre de las musas" (167) — donde musa, obviamente, también tiene la connotación que nos lleva al título de la novela: "Hay un bolero de Peruchín que se llama $<<$ Añorado encuentro $>>$ y eso fue lo que fue. Curiosas las canciones cómo dictan los recuerdos" (21).

Por un lado, el ejemplo de Boym muestra cómo ciertos elementos de la cultura, otrora indiferentes, ganan relevancia en el memoria afectada por la nostalgia. Por otro lado, De la Nuez alerta sobre las compresiones sinécdoques a las que, bajo el efecto de la nostalgia, se somete la historia, "con un discurso tan vetusto como la folclórica camisa" (El mapa 122). Mientras, Rojas nos alerta sobre las connotaciones excepcionales de la condición postsoviética en Cuba y en la diáspora cubana. Sincrónicamente, en LNI los sucesos históricos que acontecían ese año, se comprimen en apenas tres cuartillas (véase 222 a la 225, que ya hemos analizado) —una omisión relevante para nuestro estudio. Excluido el elemento perturbador, didáctico, (que es el proceso revolucionario que culminó derrocando a Fulgencio Batista en enero de 1959), el autor se concentra en el recuento de una relación amorosa, abstrayéndola de la revuelta social. Ya su novela no es más un recuento de la trama social como eje, como en Tres tristes tigres (1964). Aquí el amorío con Estela y la ciudad son la trama misma extraída del acontecer político. En la exclusión misma se detecta el drama del exiliado.

De modo que la memoria experiencial, precaria por naturaleza y sujeta a cualquier cantidad de arbitrariedades de la "nostalgia reflexiva", es caldo de cultivo de esta novela: "El Lector puede, si quiere, creer que nada ocurrió o que esta historia del periodista pobre 
y su hallazgo nunca tuvo lugar - excepto, claro, en mi memoria" (14). Pero también es un punto de partida. Todo el prólogo — que incluye la cita que precede — parece defender este punto: novelar el recuerdo echando mano a licencias literarias, sujeto el recuento detallado a la subjetividad y complejidad de la memoria selectiva: "Tuve que hacer un hueco en medio de la realidad $[\ldots]$ no había realidad fuera de mí, de nuestra realidad. Como en las películas, el tiempo en la pantalla suspendía el tiempo afuera" (13).

Lo hace también, apelando a un testimonio de lo vivido en lo que respecta a la relación amorosa, a una verosimilitud de lo referido: "la proximidad de la primera persona viene de la vida" (14), explica. Obligación equidistante a la precisión del dato topográfico — verosimilitud puesta en duda por el escepticismo ontológico del narrador para el que la experiencia es "la estela dejada por la fuga" (14). Siendo estela huella; Stella es la esposa abusada y sumisa del filme (basado en la obra teatral de Tennessee Williams) Un tranvía llamado deseo (1951); es estrella de cine o protagonista de novela (en este caso ambas); o es Stella Artois, la cerveza dorada que alcanza nuestra época ("She is a thing of beauty", reza el anuncio en la revista Miami, edición de junio de 2011); es Stella Morris la actriz de cine (actriz inglesa secundaria, con mínima filmografía con quien Estelita comparte nombre —en español—y apellido en lengua inglesa); plausiblemente hace referencia a la controvertida niña Stella-Esther, de Jonathan Swift ${ }^{47}$. A propósito, el vocablo "estela", apunta a la fugacidad de la relación amorosa narrada aquí.

\footnotetext{
${ }^{47}$ Nos remite a una relación controvertida entre un adulto y una niña. A Journal to Stella (1910-1913) es una especie de diario epistolar de Swift, de cartas dirigidas a su amiga Esther Jonson, cuyo sobrenombre era Stella. Alrededor de la relación entre Swift y "Stella" hubo gran controversia, ya que ambos se conocieron cuando ella tenía 8 años, siendo la hija de uno de los sirvientes del escritor adulto. Swift se convirtió en el tutor y mentor de la joven a la que también dedicara poemas, incluso se cree que ambos
} 
Los lectores de la obra cabrerainfanteana sabemos también que una tal Estrella es la protagonista de su relato "Ella cantaba boleros" — fotografiada en vida (vida fugaz) por el narrador de dicho cuento, Códac o Kódac/Jesse Fernández (personaje real en las novelas de CI, siendo amigo íntimo del autor), quien a su vez fue fotógrafo de las estrellas de la época (la itálica es nuestra) ${ }^{48}$. La Estrella de dicho relato —que encarnaba a la cantante Freddy, voz legendaria en la noche habanera- muere prematuramente (aunque circunstancias diferentes a la protagonista de LNI), pero que comparte nombre casi idéntico con la Estela de LNI y muerte prematura. Estelita es, finalmente (también póstumamente), Elena en Cuerpos divinos (2010), calco menos novelado, dentro de "una novela que solo fue una biografía velada" (Cabrera Infante, Cuerpos 3$)^{49}$.

\section{B. Modalidad ciudadificación-de-Estela ${ }^{50}$}

Elizabeth Grosz en su ensayo "Bodies-Cities", elabora una sugestiva tesis sobre la relación entre cuerpo humano y ciudad. Para Grosz, la ciudad está constituida “como un simulacro del cuerpo, y el cuerpo en su lugar se "ciudadifica", se urbaniza distintivamente en un cuerpo metropolitano (242). De cierta manera coincide con

contrajeron matrimonio secretamente. Entrevistada por Ángel S. Harguindey para el diario El País, en el año 2007, la viuda de CI, Miriam Gómez, dijo: "Yo creo que la protagonista, Estela, no tenía 16 años, era mayor, aunque, a la vez, es una forma de rendir tributo a Jonathan Swift y a su joven dama Stella-Esther".

${ }^{48}$ Primeramente fue un relato breve incluido en Tres Tristes Tigres (1964); más tarde dio título a un libro de relatos y viñetas: Ella cantaba boleros (1996), (véase página 399).

${ }^{49}$ José Quiroga, en su ensayo "Boleros, Divas, and Identity Motels", incluido en Cuba, the Elusive Nation (2000), ve en la muerte de esta Estrella una alegoría de la nación cubana "rentada en virtud de la transformación acaecida con el cambio revolucionario" (123-24). Como la isla, Estrella desaparece en algún lugar del Golfo de México; como en LNI, el protagonista casado de ECB (alter ego del autor), tiene una relación ilícita con Estrella. Coincidencias a partir de las cuales puede argüirse que esta metáfora de nación se extiende a Estelita, la protagonista de LNI.

${ }^{50}$ El término ciudadificación lo pedimos prestado a Elizabeth Grosz. Grosz utiliza el término en inglés "citified" que hemos traducido como "ciudadificar" (o "ciudadificación" de acuerdo al caso). Véase página 245. 
Aristóteles: para Grosz no se podrá hablar de espacio sin especificar el cuerpo que lo ocupa $^{51}$. Para Grosz las ciudades son cuerpos y los cuerpos ciudades, centrándose en la relación entre cuerpo y espacio — refiriéndonos aquí al cuerpo orgánico, biológico. Grosz analiza dos modelos básicos del cuerpo político que organizan y cohesionan la ciudad, donde se sobrepone la noción paralela entre cuerpo y ciudad. El primer modelo presenta la ciudad como reflexión, proyección o producto de los cuerpos. Dice Grosz: "La ciudad es una reflexión, proyección, o producto del cuerpo" (245).

Lo paradójico que encontramos al adaptar esa definición de Grosz a LNI, es que el cuerpo-ciudad de $\mathrm{CI} —$ se verá representado como cuerpo femenino, ciudad-mujer— está abstraído del modelo masculino-falocéntrico ${ }^{52}$ de lo político que ocupa a Grosz (la autora expresa sus reservas con este modelo como una "construcción artificial" (247). Es decir, el ámbito de lo político apenas está referido en la novela — solamente aludido al margen de la trama en las páginas 222-23 (omitido en mala fe, como ya hemos constatado). El devenir histórico que sabemos sacudía La Habana de 1957, aparece como un flash, igual de instantáneo, vagamente mencionado al paso, como para no haberse omitido con toda intencionalidad: "No habían pasado seis meses del asalto al Palacio Presidencial, que terminó entre sangre y el fracaso. Dos de los actores de una acción paralela —el asalto a la CMQ para radiar una arenga revolucionaria — habían venido a

\footnotetext{
${ }^{51}$ Véase nuestro Capítulo I, para verificar ésta asociación con las ideas del filósofo. El ensayo de Grosz, "Bodies-Cities" está incluido en Sexuality \& Space (1992). La impecable edición de Beatriz Colomina reúne a varios estudiosos de la arquitectura, desde un enfoque del espacio que ocupa la estructura arquitectónica y/o urbanística como representación, ya sea de lo político, del tejido social, o del ámbito doméstico, privado, etc.

${ }^{52}$ Grosz expresa sus reservas ante un modelo morfológico de la ciudad con "lo implícito falocéntrico codificado en el cuerpo-político que, mientras reclama que modela el cuerpo humano, usa al sujeto masculino para representar lo humano" (247).
} 
refugiarse a mi casa" (222), dice el narrador/autor sin ahondar en el tema (lo que ya hemos analizado como la mala fe sartreana). En apenas dos cuartillas, de igual modo frugal, se alude la censura que se imponía a la revista para la que él trabajaba, en boca de una amiga:

— No se dice nada. Nadie habla nada. La censura es benévola pero firme. También es, como toda censura, amenazante.

— Pero estamos en estado de guerra — dijo Olga vehemente—. Es una guerra en todo el país.

— No en el mío. (224)

En el énfasis de "su" país, corrobora la arbitrariedad de la omisión señalada. G vive (o/y narra) en mala fe. Lo que nos lleva a la segunda formulación que analiza Grosz, y que consiste en el isomorfismo entre cuerpo y ciudad, donde ambos se ven como análogos, siendo uno el reflejo del otro, "contrapartidas congruentes" (246). Pero mientras en la ciudad delineada por Grosz, el elemento falocéntrico del cuerpo-ciudad viene dado por el Estado y sus ramificaciones, en LNI el Estado falocéntrico está omitido, quedando prácticamente fuera del relato.

Sin embargo, notamos que en la manera cabrerainfanteana de "ciudadificar", de instrumentalizar a la amante — la ciudad isomorfa Estela — ya es una manera sublimada, comprimida, de falocentrismo, que a G le parece bien: "No creo que esté mal que la historia de una mujer empiece con un hombre" (LNI 22). Es decir, excluir el orden político — visto desde un prisma groszeano como subjetivación del poder — ahora cae en el narrador/autor adulto todopoderoso, sometiendo a una adolescente inexperta: "Ya que soy el narrador tendré que hacer el papel del villano" (27). Grosz fuerza la metáfora 
preguntándose, en los paralelismos entre el cuerpo humano y la ciudad, por los órganos sexuales de ésta —omitidos del cuerpo. Apunta ella que no se le atribuye sexo al cuerpo citadino - cuerpo-ciudad distribuido en un orden social que usualmente se identifica con el Estado falocéntrico, y se pregunta ${ }^{53}$ : “¿Qué es lo que toma el lugar en la función metafórica de los genitales en el cuerpo político?” (246). Explorémoslo en LNI, avanzando la idea cuerpo-ciudad de Estelita/La Habana.

Se sabe, para CI la ciudad es un territorio explorable y sensual: "La Habana era para mí entonces una isla encantada de la que era a la vez explorador y guía" (21), dice en el prólogo. No perdamos de vista la sinécdoque que adelanta la ciudad por la isla toda, siendo la ciudad una especie de ADN de la experiencia de la isla. A través de la lectura vemos que su ciudad se camina: "He vuelto a recorrer La Rampa anoche" (21), se huele: "El Vedado olía a limpio temprano en la mañana" (124), se escucha en la banda sonora de la experiencia: "Sucede que el ensayo lo escribo ahora. Entonces sólo oí la música" (20). El cuerpo-ciudad tiene cuevas (casualmente La Cuevita es un tugurio que visitan los empleados de la revista Carteles), recovecos por estrenarse: “La Habana era joven y yo también" (21). La ciudad es sujeto femenino como la Estelita fugaz — lo que justificaría en parte la exclusión de lo político en la novela - cuerpo de lo político-falocéntrico de Grosz — a lo que volveremos más tarde ${ }^{54}$ : "La Habana, qué duda cabe, era el centro de mi

\footnotetext{
${ }^{53}$ Grosz declara sus reservas frente a este modelo: "El estado se ve como un paralelo de cuerpo, especie de artificio que refleja la naturaleza de manera codificada: el rey representa la cabeza del cuerpo-político el pueblo es el cuerpo. La ley se ha comparado con el sistema nervioso, el ejército con los brazos, el comercio con las piernas o el estómago, etc.” (246).

${ }^{54}$ La omisión en LNI de lo político-falocéntrico será explorado más tarde en el análisis Modalidad"nostalgia-reflexiva".
} 
universo. En realidad era mi universo: una nébula clara. Recorrerla era un viaje por la galaxia. En el cielo había dos soles" (21). Veremos que la ninfa es dorada como un sol. El joven periodista sale una tarde a la caza del "Añorado encuentro" (21): "Digo que no la conocí y debo decir que la encontré; en la calle, una tarde, cuando era una despistada de los suburbios en el centro de La Habana, perdida" (20). Era una tarde de junio de 1957: "Iba por La Rampa con mis calobares [sic] defendiendo mis ojos del doble reflector del Malecón y el mar fulgente, refulgente, como espejo doble que esperara la reflexión dual de Venus" (27). Coincidentemente, Estela también es "refulgente" como la ciudad inundada por la luz, siendo "rubia" o "rubita", "envuelta en un halo dorado" (2829). A través de la novela las cualidades de la ciudad y de Estela, serán intercambiables. Porque él la fija en el topos, la "graba" en el lugar del recuerdo: "Recordarla a ella es grabarla en el recuerdo. Yo la recuerdo toda" (107).

Para el primer encuentro, como una aparición fílmica (no podía ser de oro modo), Estela tiene tras sí el mar, al fondo de la calle 23 (Véase fotografía X): “Al fondo, el Malecón era un telón pintado de recortado que se veía el paisaje marino", ofreciendo una imagen que subyuga al protagonista: "Ella estaba allí a la sombra, pero el pelo, el cutis y sus ojos brillaban como si le cayera un rayo de sol para ella sola (28), y continúa: "Ella era encantadora pero yo era el encantado" (30). Enmarcándola definitivamente en el topos, "ciudadificando" a Estelita: "Estaba ahí inolvidable. Es decir, fijada para siempre en el recuerdo, en la calle 23 esquina 10" (98).

Vemos el binomio cuerpo-ciudad de Estela/La Habana reflejadas en él: “detenida un instante en el espacio para detenerse para siempre en el tiempo" (29). Tanto así, que 
transferible, a Estela puede marcársele en el espacio y el tiempo — así lo estima desde el imperativo que sigue:

Atrapa el día —o más bien la noche. No, el día. El día entero. Márcalo con una piedra blanca. ¿Qué tal el peñón blanco del hotel? Márcalo. ¿Y sus ojos? Márcalos también. Marca el día, atrápalo, cógelos por las tetas [sic]. Teticas [sic] más bien. Márcalo por favor, no seas dejado. Marca el día. Era el 16 de junio de 1957. (61)

“Ciudadificación” es el acto de la ciudad de hacerse piel de Estelita; es el acto de interpenetración de ambas. El cuerpo fenomenológico de Estelita y el de la ciudad, se hacen intercambiables e interpenetrables. Lo fenomenológico es la ciudad física -que deja de serlo siendo memoria fílmica. Lo fenomenológico espacial es también el ser Estela -además, bachelardeanamente el ser Guillermo o G-como dice llamarse en la novela. Cada paso ulterior contiene al otro. No es que sean lo mismo, no toda Estela se pierde en la ciudad y viceversa; ahondémoslo.

A propósito de "ciudadificación” quisiéramos comentar el estudio de Steven M. Rosen, Topologies of the Flesh (2006).Veamos la propuesta de Rosen como herramienta de abstracción que nos facilite y expanda la comprensión y el uso del término “ciudadificación” de Grosz. Rosen propone una variante de esta ciencia (la topología), donde el cuerpo va a cambiar su forma pero manteniendo su continuidad (4) $-\mathrm{o}$ su esencia, si se quiere. Propone así un modelo del cuerpo que supera el dualismo clásico (mente-cuerpo), presentándolo como una inflexión de la mente en el cuerpo y del cuerpo en la mente (17). Para ilustrar esta mediación Rosen trae como ejemplo la botella Klein (véase ILUSTRACIÓN 1): el cuerpo está dentro de lo espacial, lo espacial está contenido 
en el cuerpo. Rosen llama a esto "uroborización" - de uroboros: la serpiente que se traga a ella misma, hecha botella (38).

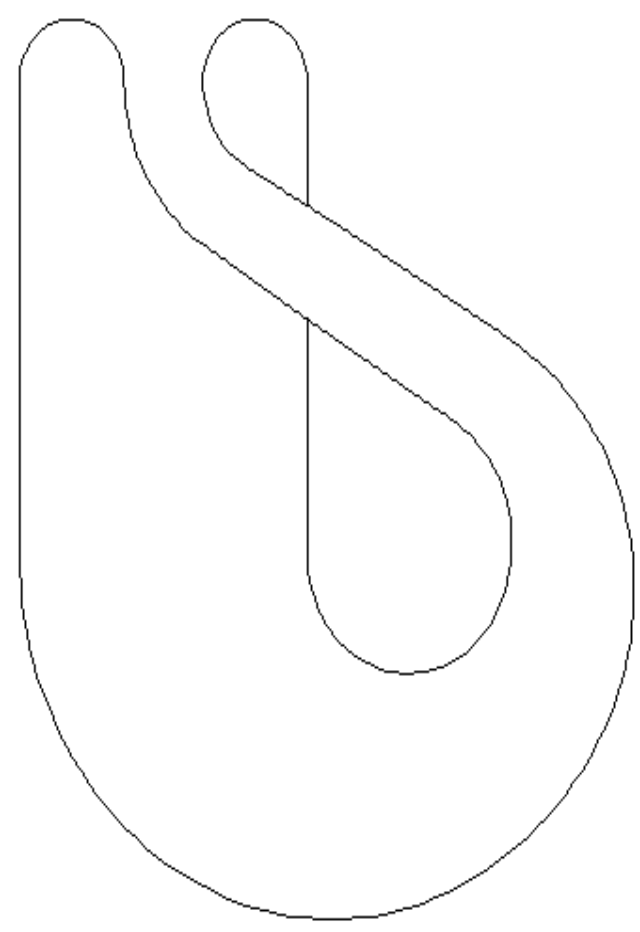

\section{ILUSTRACIÓN 1. Botella Klein}

Para Rosen, apoyándose en la noción de Merleau-Ponty ${ }^{55}$, "la carne" es un desdoblamiento del cuerpo, una proyección del cuerpo sobre sí mismo (29). La carne es entonces, a la manera antigua, un elemento como el aire, el fuego, la tierra; es una especie de principio hecho carne, cuerpo — sugiriendo que "la carne" es un elemento del ser. De modo que la botella Klein nos parece una figura topográfica indicada para describir la

\footnotetext{
${ }^{55}$ Para Merleau-Ponty la carne es casi un elemento mágico: "La carne no es materia, en el sentido de corpúsculos de ser [...] no es la mente, no es una sustancia. Para designarlo necesitamos una palabra antigua, 'elemento' en el sentido que fue usado para hablar del agua, el aire, la tierra, y el fuego. Es decir, en sentido de una cosa general, a la mitad de lo espacio-temporal y de la idea misma, una especie de principio hecho carne que sugiere una manera de ser donde quiera que haya un fragmento de ser. La carne es en este sentido un elemento del ser" (Rosen 25).
} 
"ciudadificación" de Estelita: la piel de Estelita "ciudadifica", se extiende, se recoge en sus bordes, se ilumina: como La Habana, Estela es una superficie explorable:

Su piel era su frontera. Detrás había un mundo oscuro, feral, una selva salvaje y misteriosa. Ella, como todo territorio inexplorado, atraía y daba miedo a la vez. Fui yo quien la descubrió, pero su exploración (nunca pude hablar de conquista) fue costosa. Sólo me salvó mi instinto de conservación, que ha sido desde niño una suerte de ángel de la guarda. (207)

¿Cómo es la piel de Estelita? Según dice: "La piel dulce. Con labia en su cuerpo.

Grandes labios, breves labios. Su sexo no sólo estaba entre sus piernas, sino que se extendía por todo el cuerpo como una segunda piel" (146-47). Como contrapartida complementaria, el mar es la frontera de la ciudad, piel de ciudad, su límite: "El Malecón y el muro eran de color arena que parecía una playa de cartón piedra aunque era de doble cemento armado. Ahí en el Malecón terminaba La Habana. El resto era el mar” (28). Ambas son una cosa, en términos de Rosen, sin ser absorbidas del todo la una por la otra; mejor aún, conservando su "continuidad" la una en la otra, como la botella Klein (Rosen 4). No se caiga en el error de asumir que el mar está fuera de la ciudad — como veremos también en nuestro análisis de la novela de WG, quien se zambulle en el Malecón un par de veces para aliviarse, más no logra escapar de la ciudad — el mar está incorporado en la “ciudadificación” Estela. El mar, en tanto que límite, es parte del cuerpo-ciudad.

Entonces cabe preguntarse, siendo el cuerpo-ciudad mujer, ¿cuáles son sus órganos sexuales femeninos?, ¿acaso el night-club El Atelier cual madriguera oscura, al 
que acuden los amantes $?^{56}$, o tal vez la propia Estelita sea este órgano de ciudad (visto desde la morfología de Grosz). El paralelo entre ciudad y amante se hace palpable: ambas se exploran, se gozan. Sin embargo, a pesar de que Estelita "llevaba el sexo literalmente a flor de piel” (146), es sexualmente apática: "No le interesaba el sexo, ningún sexo [...] Era, lo creo ahora, patológicamente incapaz de ningún afecto [...] Tal vez fuera el demasiado sol que crea cortinas a la moral" (217). Instrumentales ambas, por el momento la ciudad y Estela son medios para fines existenciales de convivencia y goce, no necesitan responder al estímulo, sino dejarse hacer, andar y desandar: "El sol se pone todos los días, mañana como ayer, pero ella estaba ahí ahora, caminando a mi lado, cálida como la tarde, y ella era el presente. Carpe diem, me aconsejó una voz antigua" (39).

Observamos que lo político-falocéntrico del modelo analizado por Grosz, no se halla en LNI ya que paradójicamente no está en el poder del Estado y sus brazos organizativos (omitidos en LNI). En LNI, G encarna el poder (ya que todo poder y querer está en sus manos: es quien recuerda, es el adulto en posesión de una niña): "Como soy yo el que escribe estas páginas (y obviamente no ella) es que trato de recobrarla. No sólo en la memoria (no he dejado de recordarla nunca) sino en mis memorias. Ella es un cuerpo divino pero también un fantasma que ronda mis recuerdos" (218). El demiurgo sigue la receta que dicta el bolero del compositor José Antonio Méndez, cuando todopoderoso respalda que: "Hay que imputarle al destino su sórdida manipulación de la esperanza" (105).

\footnotetext{
${ }^{56}$ El Atelier es un night-club habanero al que van los amantes de esta historia en un momento determinado. Volveremos más ampliamente sobre este punto.
} 
Estallan las metáforas para una "ciudadificación” del goce que encarna Estela cual objeto del deseo, órgano sexual del cuerpo-ciudad, y el azar la pone en el camino: "La luna como ella, era de color de miel ahora al salir a la calle vertiginosa que se deja llamar por un número como si fuera un billete de lotería" (105). Veremos que el narrador desea el cuerpo-ciudad de la protagonista, aún niña, la seduce y la posee, desvirgándola, y como en las calles de la ciudad, se pierde en ella. Como la ciudad, la describe en detalles, atraído la ausculta, andándola de un extremo a otro, como cartógrafo aficionado — tautología citadina — como flâneur, y como amante: Le sabe las coordenadas, goza la vanidad de sabérselas al sujeto/objeto. La ciudad, ubicua, metamorfosea cuerpo-ciudad.

La ciudad está tan íntimamente ligada a la experiencia Estela, que las calles de La Habana, vienen siendo las venas y arterias del cuerpo-ciudad, siendo la circulación sanguínea análoga al tráfico urbano. Vitalidad de un cuerpo-ciudad que lo entrampa. Constatémoslo en la analogía de la siguiente cita (cuando G lleva a Estelita a la posada para compartir la primera noche juntos, y explica el placer que le produce el cuerpociudad Estela): "Placer, terreno llano sin cultivar en el interior de una ciudad. Gusto con que se hace o se consiente cierta cosa. Cosa que produce alegría" (111).

Nótese que ella es la realidad, pero también, puede comprobarse más adelante, ella se refiere a la protagonista; lo que encierra una metáfora expansiva: ella es la realidad, el topos, que es la ciudad, es la experiencia de la ciudad, análoga al cuerpo físico de la amante se pulveriza, es todo:

Ella se había encargado de contaminarlo todo. Ese verano ella lo había dominado todo como domina una bacteria la vida. Pero había sido, en un momento de nuestro encuentro, una querida bacteria que produjo una 
infección amable. Larvado viví y estuve enfermo por un tiempo. Pero no

había realidad fuera de mí, de nuestra realidad. (14)

Estela domina el espacio-tiempo de lo que "fue un momento en el momento" (36).

La habanidad de Estela y la estelicidad de La Habana, consumadas, titilantes en la memoria fílmica: "Y pensar que ella no existe más que cuando la imagino o la recuerdo" (20).

\section{Modalidad cinta-fílmica-de-la-memoria}

La técnica cinematográfica es parecida al "cómo" recordamos ${ }^{57}$. La memoria viene a ser ese archivo que activamos en imágenes primero, olores, sensaciones. Está también ese componente de inmaterialidad de la memoria que como facultad activa nos remite al reverie bachelardeano, espacio donde se fragua el ser, un ser que es, desde su prisma fenomenológico, todo intencionalidad. Ese soñar despierto, le permite a CI revivir un pasado secuencial, novelado. Para un consumado cinéfilo y crítico de cine como CI, la cinta fílmica de la memoria se convierte, no sólo en archivo de la realidad física, en algo mejor aún: versiones e interpretaciones de ese pasado. He aquí una cita metaficticia del prólogo de LNI que contiene nuestra tesis:

Como en las películas, el tiempo en la pantalla suspendía el tiempo afuera. Pero — eso lo veo ahora—la vida no es una película, por muy real que sea la vida. ¿Qué decir de los efectos especiales? La narración intenta llenar ese vacío, pero ese vacío es el centro de la narración porque era, ¿quién lo

\footnotetext{
${ }^{57}$ De cierta manera, como dice Sigfried Kracauer en su análisis del film como grabador de historias, una película está hecha de "imágenes de la memoria": "Las películas vienen en su propio registro y cuando se revela la realidad física" (Casey 30), La idea de registro o archivo de Kracauer complementa esa imagen heideggereana que "a la mano" ("Zuhandenheit"), que hemos abordado, como la inmediatez de estas imágenes de la memoria.
} 
diría?, la propia Estelita. Una vez más, sólo la estela dejada por la fuga.

Asumamos "el tiempo en la pantalla" de la memoria se completa, en su minucia de la experiencia extraviada, con la intencionalidad de la ficción. Para abordar el tratamiento que CI le da a la memoria, trataremos de responder algunas preguntas como: ¿Qué parte del autor no está en la historia?; visto como cine, ¿qué se omite de la cinta de imágenes?

La novela es presentada como las memorias de G: narrador, protagonista, alter ego del autor (quien bien pudiera ser Silvestre ${ }^{58}$ ) — apelando a la memoria experiencial. Toma lugar en un tiempo preciso: verano de $1957^{59}$ (la acción transcurre entre el tiempo narrativo de Tres tristes tigres (1964) y La Habana para un Infante difunto (1979). La historia acontece en el vértice de hechos sociales que cambiarían la realidad cubana, y habanera para siempre - preámbulo ideal para "una historia de amor de locura y de muerte" (LNI 133), enmarcada en la ciudad de La Habana. Siendo el protagonista periodista de la revista Carteles, con sede en Avenida Menocal y Peñalver, en La Habana Vieja, fungiendo como crítico de cine —como el autor en la misma época (de 1954 a 1960). Revista donde también trabajaban colegas reales de CI fungiendo aquí como personajes. Ambivalencia del texto, entre "ficción autobiográfica o autobiografia imaginaria" (Souza 140), que es una marca de estilo del autor.

\footnotetext{
${ }^{58}$ Silvestre es el personaje que interviene intermitentemente en la obra cabrerainfanteana. Aparece repetidas veces en Tres Tristes Tigres (1964) y protagoniza varios relatos anteriores en Así en la paz como en la guerra (1960). Los críticos coinciden en que Silvestre sea un alter ego del autor porque, además de coincidencias biográficas, exhibe la misma afición por el cine, por la música, por la ciudad de La Habana siendo una especie de flâneur inmerso en el recuerdo.

59 "La acción transcurre entre La Habana para un infante difunto y Tres tristes tigres" - confirma Miriam Gómez entrevistada por Ángel S. Harguindey- Madrid - 09/11/2007, en elpaís.com.
} 
Llamémosle preámbulo amoroso a esta historia, que se escurría paralela a eventos sociopolíticos que — como se ha visto — el autor deja fuera del relato. CI parece confesar este amorío con la niña, como si de un dato biográfico se tratara: "Pudiera escribir mentiras, ya lo sé, pero la verdad es suficiente invención” (20). Para comprenderlo, abordemos la película de su vida: En poco menos de dos años se sucedieron otros percances en la vida del autor/personaje, que ya empezaban a conformarse en $1957^{60}$. CI formó parte de un grupo de jóvenes entusiasmados por la Revolución que arrancara el 1ro de enero de 1959, pero divergentes del curso monolítico que comenzaban a perfilarse en su seno. La actitud crítica de estos jóvenes no pasó inadvertida a las autoridades dirigentes, y viceversa: Roberto Blanly (personaje en LNI), Humberto Arenal, Calvert Casey, Julio Matas, Heberto Padilla, entre otros, detectaban las inconsistencias del discurso dirigente. Lo que desencadenó en los célebres sucesos donde se evidenció la intención totalizante de la dirigencia del país -causando inquietud en los jóvenes escritores e intelectuales que le apostaron.

En el año 1959 CI pasa a dirigir Lunes (el tiempo que duró 1959-61), suplemento del periódico Revolución. Al respecto, Dinorah Hernández Lima ${ }^{61}$ resume los hechos:

\footnotetext{
${ }^{60}$ A raíz del corto P.M. (1960) que dirigieran Orlando Jiménez Leal y Sabá Cabrera Infante- -hermano del autor-fuera prohibido en 1961 por Castro, la relación de CI con el régimen se enfrío considerablemente. La prohibición del cortometraje desató una polémica que desencadenó en la clausura del semanario Lunes de Revolución ese mismo año. En 1962, CI fue enviado a Bruselas como agregado cultural de la embajada cubana en esa capital. Durante su estancia en Bélgica, publica Un oficio del siglo XX (1963). Allí vive con las dos hijas de su primer matrimonio y su mujer Miriam Gómez hasta 1965. Ese año, debido a la muerte de su madre, vuelve a la isla. Allí es retenido durante cuatro meses por el Servicio de Contra-Inteligencia. Entonces sale al exilio, primero en España, luego en Londres, donde se establecerá definitivamente.

${ }^{61}$ Dinorah Hernández Lima: En Versiones y re-versiones históricas en la obra de Cabrera Infante (1990).
} 
El éxito de Lunes y del periódico Revolución no pudo evitar que su vida fuese breve. En 1961, en una reunión de intelectuales convocados por Edith García Buchaca, presidenta del recién creado Consejo Nacional de Cultura, y en la que tomó parte el propio Fidel Castro, Lunes y Revolución, conjuntamente con sus editores, fueron acusados de dividir las filas de la revolución. Esta acusación fue llevada al Primer Congreso de Escritores y Artistas de Cuba celebrado en agosto de 1961, donde se ratificó la clausura. (42)

Lunes queda clausurado, pero nace, en el mismo congreso, la Unión de Escritores y Artistas de Cuba (UNEAC) impulsando dos revistas, una quincenal y otra bimensual respectivamente: La Gaceta de Cuba y Unión. Ambas publicaciones siguen la línea trazada por el célebre dictamen de Fidel Castro — a raíz de la clausura de Lunes: "Dentro de la Revolución todo, contra la Revolución nada"62. Ya en 1960 se había creado la Fundación de la Casa de las Américas, que gradualmente acataría las nuevas directrices

${ }^{62}$ En los días 16, 23 y 30 de junio de 1961 se efectuaron, en La Habana, en el Salón de Actos de la Biblioteca Nacional, reuniones en las que participaron las figuras más representativas de la intelectualidad cubana. Artistas y escritores discutieron y expusieron sus puntos de vista, dudas y preocupaciones sobre distintos aspectos de la actividad cultural y sobre los problemas relacionados con sus posibilidades de creación, ante el Presidente de la República, Dr. Osvaldo Dorticós Torrado, el Primer Ministro, Dr. Fidel Castro, el Ministro de Educación, Dr. Armando Hart, los miembros del Consejo Nacional de Cultura y otras figuras representativas del Gobierno. El célebre discurso de Fidel Castro, "Palabras a los intelectuales", marcó la dirección totalizante de la Revolución cubana: "La Revolución tiene que comprender esa realidad y, por lo tanto, debe actuar de manera que todo ese sector de artistas y de intelectuales que no sean genuinamente revolucionarios, encuentre dentro de la Revolución un campo donde trabajar y crear y que su espíritu creador, aun cuando no sean escritores o artistas revolucionarios, tenga oportunidad y libertad para expresarse, dentro de la Revolución. Esto significa que dentro de la Revolución, todo; contra la Revolución nada. Contra la Revolución nada, porque la Revolución tiene también sus derechos y el primer derecho de la Revolución es el derecho a existir y frente al derecho de la Revolución de ser y de existir, nadie. Por cuanto la Revolución comprende los intereses del pueblo, por cuanto la Revolución significa los intereses de la Nación entera, nadie puede alegar con razón un derecho contra ella. Creo que esto es bien claro. ¿Cuáles son los derechos de los escritores y de los artistas revolucionarios o no revolucionarios? Dentro de la Revolución: todo; contra la Revolución ningún derecho. (APLAUSOS)." Véase nuestra bibliografía para fuente. 
estatales, desde un jurado que otorgaría premios a las obras representativas del proceso revolucionario. A partir de estos hechos muchos escritores, artistas e intelectuales, entre los que se encontraba Cabrera Infante, se sintieron defraudados con el proceso revolucionario desde adentro. Hernández Lima agrupa a estos escritores, artistas e intelectuales, por conformar una primera etapa y tomar parte activa en la historia, dentro de la Generación de la Revolución (43).

Es importante reiterar que toda la tensión social explicada aquí, y de la que el autor formaba parte activa, queda fuera del relato en LNI. Pero el narrador que recuerda, y relata el preámbulo amoroso (hemos venido a llamar), sabe de ello -ya lo había vivido al embarcase a escribirla: "El pasado sólo se hace viable a través de un presente ficticioy sin embargo toda ficción perecerá. No quedará entonces del pasado más que la memoria personal, intransferible" (LNI 18) —memoria moldeable.

Para redondear la noción de la memoria como cine, ahondemos algo más en este aspecto selectivo de la memoria que se aviene a la edición fílmica (sintomático, según Svetlana Boym, quien lo adscribe a la "nostalgia reflexiva"). Tomemos como ejemplo cuando G lleva a Estelita a El Atelier — referido como night-club que funciona en pleno día. El narrador refiere con la meticulosidad geográfica que le caracteriza (no podría ser de otro modo), que este piano bar se ubica en la calle 17 y la 10 Avenida, en el corazón del reparto habanero El Vedado. La técnica consiste en ofrecer el dato topográfico correcto, a modo de que el lector no ponga en duda que lo recordado también es referido con la misma precisión. Lo que nos presenta con el hecho histórico individual siendo correlativo al mapa de la ciudad, al detalle de su fachada, pretendiendo una equivalente credibilidad con la anécdota. 
Revisitemos la escena en El Atelier en contrapunto con Bachelard: El night-club al que acuden los amantes una tarde, está absolutamente a oscuras — como si entrásemos a una sala cine. Pero la luz de la imaginación reavivará la memoria del momento, según Bachelard: "Toda memoria tiene que reimaginarse. Toda memoria tiene microfilms [sic] que sólo pueden ser leídos si reciben la luz viva de la imaginación" (PDE 212). Vemos como $\mathrm{G}$ juega con la encandiladora luz isleña afuera, y la oscuridad total en el interior de El Atelier, antojándosenos, siguiendo la línea de pensamiento bachelardeana, un trazo paralelo con la memoria ${ }^{63}$. Supongamos entonces la siguiente polifonía: G rescata la luz de la memoria de las sombras del olvido. Dice así:

La frase oscuridad al mediodía, tan raída, tan llevada, parece querer ser una metáfora del infierno, pero ahora pasando de la claridad cenital de la calle 17, sin tranvía ya pero todavía con raíles que brillaban como cromo, entro, entramos, entra ella conmigo del sol a la noche del justamente llamado night-club aún de día. (LNI 101)

Obsérvese cómo, figurativamente, nos refiere por medio de contrastes, símiles y metáforas lo que parece abrirse paso como memoria en el tiempo y el olvido: "sol cegador y la ceguera de adentro", "más oscuro que un túnel”, "cámara oscura”, "espesa niebla", "oscuridad perenne", "maître de noir" para referirse al maître que guía a la pareja en la "tiniebla artificial" (101). En la atmósfera de film noir no puede faltar la música ominosa y sensual, también abriéndose paso en lo oscuro: “¿y esa música? Venía de algún lugar oscuro todavía más oscuro" (103). Embarcándose en el juego de contrastes

\footnotetext{
${ }^{63}$ Para el avance de esta investigación, sería conveniente aceptar lo que para Bachelard es deliberadamente fenomenológico, y que llamamos la ontología de la memoria: es el soñador despierto (el escritor en este caso) quien crea las variantes de sus imágenes y las sortea.
} 
cual lúdico editor de cine, superpone imágenes: "Por lo menos el pianista veía las teclas blancas saliendo de las teclas negras como el mismo maître músico" (101).

La joven está incómoda allí, G — siempre reflexivo — está encantado. Al piano Peruchín canta, además de un popurrí de boleros, un título nostálgico: “Añorado encuentro". Como contrapunto, el desencuentro entre ambos es parte de la ecuación, ya que CI explícitamente rescata lo que quiere recordar de la oscuridad de la memoria de G, construyendo una estampa inconstante ${ }^{64}$ : "Pero lo que recuerdo ahora es lo que quiero recordar" (107). El vocablo "inconstante" aquí lo utilizamos con significado expansivo, ya que esa cualidad inconstante de la protagonista que alude el título, es también una cualidad de la memoria que oscila ${ }^{65}$, en una dinámica que el cine es capaz de plasmar con creces por medio del flash-back, y otras técnicas cinematográficas como la foto fija, fadeout, la cámara dolly, los elipsis, etc.

En la concepción misma del personaje Estela, vemos un arquetipo fílmico bicéfalo: la Lolita y la femme fatale: "Pero no era una mujer, era apenas una muchacha, una muchachita vestida como la heroína francesa de las películas que yo tanto había celebrado" (97). La niña precoz allí mismo en El Atelier llorará conmovida por el dramatismo del bolero “¿o eran falsas lágrimas de glicerina?” — se pregunta G como si de una actriz de cine se tratara. "Hay que decir que ella era todo un personaje" (20), que es una manera de encarnar el arquetipo.

\footnotetext{
${ }^{64}$ La memoria "que viene y va, viene y va": nos refería MG (léase la anécdota que encabeza este capítulo). Y que también Bachelard constata como cualidad del reverie del escritor: "las obras de arte son los subproductos de este existencialismo del ser imaginante" (Casey 221).

${ }^{65}$ Nos referimos a la connotación que CI (vía Miriam Gómez) otorgara a la memoria: "lo que tiene la memoria, que bota lo que no quiere; lo que no quiere viene y va, viene y va" (citando a CI, refirió Miriam Gómez en su comparecencia en la Feria Internacional del Libro de Miami 2008, (véase anécdota que encabeza este capítulo).
} 
De hecho Estelita tiene cualidades histriónicas adjudicadas a propósito de la representación:

— Quiero que mates a mamá —me dijo.

Creí que no había oído bien. Todavía tenía los ojos de inocencia pero no había pestañeado una sola vez. Los ojos que no pestañean crean una mirada peligrosa. O ella había leído las mismas novelas policíacas que yo leí o habíamos vistos las mismas películas negras en que Barbara Stanwick le pide a Van Heflin que mate a Kirk Douglas. (83)

La niña de quince años — siempre ligera de ropas— se conduce como un personaje de película: "Ella era una persona pero ha terminado convertida en ese destino terrible, un personaje" (20). De hecho la descripción de Estela muchas veces nos llega por asociaciones a actrices de cine: "Se parecía, lo juro, a Brigitte Bardot. Era una cruza entre Mylène Demongeot, que copiaba a Brigitte Bardot, y Françoise Arnoul” (65). El cinéfilo recrea su personaje a la medida: "mi versión de la rubia de oro. Mi ánima versión” (71), confiesa. La convierte en personaje o la reconoce en su devenir arquetipo: "Era la mujer, mejor la muchacha, que originó este libro" (64).

Hay mucho de farsa también, de cliché fílmico en la concepción del personaje Estela, que es una manera del autor (y de G) reírse de la realidad que imita al cine: ¿Sería una Lizzie Borden ${ }^{66}$ del trópico? (85) — se pregunta comparándola con una presunta asesina célebre. Es así cómo en la Estelita/Lolita de CI se dan el ángel y el demonio: “de los pómulos a la barbilla, estaba cubierta con un breve vello que vibraba a la vista como

\footnotetext{
${ }^{66}$ Lizzie Borden fue un personaje real llevado al cine, debido a que se sospecha que asesinó a su padre y madrastra con un hacha mientras dormían. La culpabilidad nunca pudo probársele por lo que salió absuelta. Véase la página 85 de LNI para la referencia paródica completa.
} 
si fuera una capa de polvo que brillaba al resplandor [...] refulgía y le hacía la cara de un espectro rubio" (97) —dice de su aspecto de espíritu celeste. Pero no hallaremos tal pureza angelical en su deseo de asesinar a la madrastra: "Ella se había revelado —o más bien rebelado - como una muchacha dura, rubia pero con un hilo oscuro alrededor de su cabeza" (84).

En Estela se conjugan la desvergüenza y la inocencia: no llevaba sostén debajo del vestidito blanco y "ninguna mujer respetada o respetable entonces dejaba de usar sostén [...] estaba casi, no casi, sino desnuda debajo" (53); no obstante: "Estelita tan nueva parecía recién estrenada o no estrenada todavía [...] En todo caso Virgen era" (64), llega a constatar luego. No se pase por alto la connotación que tiene "estrenada", vocablo expansivo que la hace análoga a una película por estrenarse. Irremediablemente atraído a lo que le está vedado, reconocerá más tarde: "Le temo, siempre he temido al encanto de los niños. Por eso me cautivó esta Estela. Ella era tan ajena a su encanto como a la moral" (201).

El cazador se dará por cazado: “Aún sus ojos, capaces de crear una mirada entre perversa y perdida, eran los ojos de una niña" (95). Pero la niña emplaza a G con toda intención maléfica: “-Que soy menor [...] —Quién es el cobarde ahora? [...] O tú eres un tonto. $\mathrm{O}$ te haces el tonto, que es peor. ¿No te das cuenta que no tengo dieciséis?" (68). Pero él reconoce que su insolencia no es una máscara: "no tenía lo que la gente llama conciencia $[\ldots]$ no tenía la menor noción del pecado" (146). La imagen que ofrece el narrador de esta Estela púber es lo suficientemente ambigua como para revertirse en femme fatale: “-Ya cumplí dieciséis” (109), le miente al poco tiempo, eliminando las trabas éticas y facilitando la consumación del acto sexual: "Me recuperé de mi asombro 
sin sombra, salvé las distancias y me metí en la cama: me iba a acostar con una estatua clásica" (117). Pero esta jovencita que llevaba el sexo a flor de piel porque (valga repetir la cita) — “su sexo no sólo estaba entre sus piernas, sino que se le extendía por todo el cuerpo como una segunda piel" (147) —es sexualmente indiferente, apática, o "simplemente, después de la primera noche, hostil" (207).

Con todo, se embarca en una relación ilícita con la Estela fugaz de esta historia: Ella "era del momento [...] pero daba la impresión de no tener futuro" (213). Marcado por su propensión al lente fílmico, la aosculta, la retrata: "Estelita, como un bolero de moda, siempre había sido llevada por la mala" (233). Aborda la descripción del personaje Estela una y otra vez para tratar de comprenderla — si acaso corregir su desperfectoaprehenderla en su desvarío: "Ella era carnal, próxima y muy asequible [...] Ella fue siempre para mí una interrogación difícil [...] su mirada atrayente, altiva y, ¿por qué no decirlo?, traidora" (274), tildándole el consabido cliché que reza algún bolero.

La imagen que ofrece de Estelita/Lolita se completa cuando le adjudica cualidades casi diabólicas:

Sus ojos, pálido ópalo [...] Los ojos del tigre y del diablo son también amarillos. Solamente el anillo de oro de su esclerótica era una membrana diferente. Su iris era un arco iris de un solo esplendor dorado. Pero al fondo tenía un punto ciego. (243)

También, la querubín parece tener algo de desquiciada cuando, después de hacer el amor, imitando ese gesto "visto en tantas películas, de fumar después del coito" (120), a ella le cae una ceniza encendida en el pecho, entre los senos: "No se quejó, no dijo nada 
y volvió a mirarme [...] Luego supe que los psicópatas tienen un umbral del dolor muy bajo" (244). Es ésta una Lolita que deviene femme fatale:

Esto la hizo, entonces una nueva heroína para quien la vida no era una intoxicación sino un veneno lento que había que apurar [...] No vine a ver Y Dios creó a la mujer ${ }^{67}$ sino meses más tarde después de haber dejado a Estela, pero el personaje de Julieta se le parecía tanto que al ver la película al final de ese año pude comprender un poco a Estela. Allí estaba su hastío, que no era para nada indiferencia, su cuerpo propicio al sexo, que no le interesaba para nada, su búsqueda inútil, que era en realidad un único destino. (213)

Este verano "de miseria furia y fuego" (270) tiene a la amante púber y mujer fatal de protagonista: "Nuestra relación fue un largo coitus interruptus que nunca completamos" (212). Embargado G por la sensualidad irresoluta de ella, contra la contradicción que ella encarna, se erige en personaje Estela —un personaje fílmico, una ampliación de la realidad, una mirada con lupa al arquetipo: "Nunca tuvo ella un estallido emocional. Nunca la vi fingir la menor emoción. Es más, la vi emocionarse muy pocas veces" (234). Vemos que el cuerpo-ciudad Estela es arisca a él —ciudad despersonalizada, continente contingente, contenido antipático.

En su momento, ella misma le ofrece la salida de la situación angustiosa diciéndole: “-Sí tengo remedio. La muerte” (232). Entonces él decide matarla: "Estaba enfermo. Ella era mi enfermedad. Estela era. Pero ¿cómo curarme? Fue entonces cuando

\footnotetext{
${ }^{67}$ Se refiere al filme francés Et Dieu créa la femme (1956) (Y Dios creó a la mujer, en su traducción al español) protagonizado por Brigitte Bardot, y dirigido por Roger Vadim.
} 
pensé en matarla" (232). Aunque lo planee mentalmente, nunca llevará acabo el asesinato en el filme de la memoria. Siempre desde el humor negro se justifica: "Pero los crímenes que nunca se cometen son los más exitosos: todo su arte reside en su plan o en su concepción" (241), como si de la planificación de un guión fílmico se tratara.

El remate mordaz de la niña arpía llega tiempo después de haber dado por concluida su relación con ella, cuando refiere un encuentro casual donde Estela le espeta con "sonrisa sardónica" (264):

— Me estoy acostando con tu hermano [...]

— Tiene tu misma voz. Con los ojos cerrados, en la cama eres tú.

- En la cama.

- En la cama.

Ah ciudad incestuosa. No fue lo que dije, ni siquiera lo pensé entonces. Es ahora que adopto ese tono operático. (262-63)

Ahí mismo decide abortarla del auto, devolviéndola al café Vienés donde la había encontrado; no sin antes recibir la estocada final de Estela: "Que no me falta más que tu padre” (265). Aunque él la verá a distancia un par de veces más, ya nunca más volverán a intercambiar palabras; el viaje ha concluido; la topografía de la ciudad equidistante a la de las vidas: "Nos encontramos para perdernos" (178).

Cuando la vuelve a ver por casualidad en el night-club Picasso de la calle 12, ella bailaba con otra mujer y "parecía un zombi blanco: mi versión de Christine Gordon caminando catatónica por la noche haitiana. ¿Qué sería de mí sin el cine?” —volviéndola a comparar con una actriz de cine - y nota, que "ella había viajado, se había ajado" 
(277). Sabremos desde el principio que esta Estelita murió joven, fatalidad prematura (queda fuera del relato) que la redondea como personaje:

Ella murió, lejos del trópico, de Cuba. Pero ella no era en realidad del trópico o de La Habana o de La Rampa donde la conocí - y decir que la conocí es, por supuesto, un absurdo: nunca la conocí. Ni siquiera la conozco ahora. Pero escribo sobre ella para que otros, que no la conocieron, la recuerden. En cuanto a mí, ella fue siempre inolvidable.

El personaje de Estela, perfectamente delineado como una Lolita del trópico, había evolucionado en otro arquetipo impecable de mujer fatal. Quizás G nunca llevara a cabo el asesinato porque la historia sucede en el filme de la memoria, y no en la realidad —aunque el filme/novela apele a ser verídico. Desde el humor negro vemos la hechura del texto, donde el asesinato ocurre sin ocurrir: "Ocurrió un sábado cálido a principio de septiembre. Summery execution" (242).

Es que además de la condensación de la Lolita y la femme fatale, como arquetipos del cine en la novela, el texto está impregnada de una atmósfera existencialista a la corriente nouvelle vague en el cine ${ }^{68}$ : "Los entes pasados viven porque no han muerto para nosotros [...] Nosotros somos los muertos vivientes" (17). Tal parece que carga con la memoria de la menor como un espectro: "El espíritu del pasado siempre está ahí” (17);

\footnotetext{
${ }^{68}$ La nueva ola, o nouvelle vague del cine francés es la corriente que caracteriza ese nuevo grupo de cineastas franceses surgido a finales de la década de los 50. La nueva ola surge como reacción contra el cine tradicional francés. Hay un bagaje cultural cinematográfico importante (obtenido en las Escuelas de Cine y en la Cinemateca Francesa) y una actitud crítica, cultivada en revistas como Cahiers du Cinéma. Esa nueva generación de directores eran verdaderos cinéfilos. Las películas de la nueva ola descubrieron una nueva mirada de la cámara y redefinieron el montaje (ya inspirado por el cine de Orson Wells). Entre los directores más importantes cabe nombrarse Jean Luc Godard, Claude Chabrol, Francois Truffaut, y Alain Resnais.
} 
y tal vez como una culpa moral: "Lo que le hice a Estela tiene más importancia que lo que ella me hizo a mí —o lo que nos hicimos los dos a los dos” (271)—se lamenta sin contrición.

\section{Henri Bergson y la durée}

La idea de la memoria como cine no es nueva; surge paralela a la invención del séptimo arte. Tan temprano como 1907, Henri Bergson analizaba "el aparato cinematográfico" cual analogía de cómo el intelecto absorbe la realidad. Precisamente Bergson, es uno de los primeros filósofos en usar el cine en el discurso filosófico. Para el filósofo el intelecto es, por naturaleza, un mecanismo espacializador. La inteligencia sólo puede expresar el movimiento — de la realidad misma — con términos estáticos: "se sustituye lo continuo por lo discontinuo, la movilidad con la inmovilidad" (Bergson, Obras 222-23). Este proceso es lo que Bergson compara con el cinematógrafo: La cámara se inicia con un movimiento real pero se descompone mecánicamente en una serie de cuadros individuales estáticos. Luego lo convierte en movimiento a través del aparato de proyección. Una película es una ilusión reconstruida. El cinéfilo autor de LNI y su alter ego G lo entienden asimismo: "Más allá estaba la calle deslumbrante y la acera como una faja de luz. Hasta ahora todo era topografía, pero comenzaba, sin saberlo, el verano de mi contento. Salí del cine sin haber entrado" (26). O sea, para G no hay diferencia entre cine y vida, o hay estetización de la vida.

El contexto de la metáfora anterior tiene que ver con la relación que existe entre el intelecto, la intuición y su idea del durée (o duración). Bergson habla explícitamente del cine en el capítulo IV de La evolución creadora (1907). Dice: "No percibimos del 
devenir más que estados; de la duración, instantes" (Obras 673). O sea, la inteligencia sólo puede expresar el movimiento — de la realidad misma - con términos estáticos:

Tal es el artificio del cinematógrafo. En vez de apearnos al devenir de las cosas, nos situamos como fuera de ellas con el fin de recomponer su devenir artificialmente. Nos tomamos fotos, por así de decirlo, de una realidad que pasa $[\ldots]$ Por lo tanto, podríamos resumir $[\ldots]$ que el mecanismo de nuestro conocimiento es de tipo cinematográfico ${ }^{69}$. (Obras

Dicha dinámica no está exenta de crítica. Bergson parece decir que el cine sustrae aspectos intuitivos del tiempo:

El tiempo es invención o no es absolutamente nada. Pero la física no tiene en cuenta el tiempo-invención, sujeta como está al método cinematográfico. Se limita a contar las simultaneidades entre los hechos constitutivos de este tiempo y las posiciones del móvil T sobre su trayectoria. Separa estos hechos del todo que reviste en cada momento una nueva forma y que les comunica algo de su novedad. Los considera en estado abstracto, tal como serían fuera del todo vivo, es decir, en un tiempo desenvuelto en espacio. (Obras 700)

¿Pueden integrarse estos aspectos intuitivos a la cinta cinematográfica? Gilles Deleuze parece decir que sí.

\footnotetext{
${ }^{69}$ Bergson apunta: "En lugar de ligarnos al devenir interior de las cosas, nos colocamos fuera de ellas para recomponer su devenir artificialmente. Tomamos vistas casi instantáneas de la realidad que pasa, y, como ellas son características de esta realidad, nos basta enfilarlas a lo largo de un devenir abstracto, uniforme, invisible, situado en el fondo del aparato del conocimiento, para imitar lo que hay de característico en este devenir mismo. Percepción, intelección, lenguaje proceden en general así” (Obras 700).
} 
En su libro Bergsonism (1991), Deleuze analiza la idea del durée (duración) en Bergson, como una forma explícitamente cinematográfica y ontológica (las itálicas son nuestras, Obras 731). La durée se divide en una multiplicidad: se divide y cambia, y sin embargo no son diferentes divisiones (Deleuze 42). En la durée la división produce un otro sin que sean diferentes, puesto que el número existe como potencia: es decir, existe como virtualidad. Lo virtual es una manera de actualizarse en el curso de ser actualizado. La actualización ocurre como diferenciación.

La durée es una identidad entre la memoria y "la conservación y la preservación del pasado en el presente" (Deleuze 51). El momento que sigue siempre contiene el precedente, sin embargo los dos momentos se condensan, ya que no han desaparecido cuando el próximo aparece. Es como si hubiera dos memorias: contracción de memoria, y recolección de memoria.

CI parece reclamar para la lectura (en el prólogo de LNI), la misma noción bergsoneana pasada por el filtro de Deleuze; constatemos la sorprendente coincidencia:

Esta narración está siempre en el presente a pesar del tiempo de los verbos, que son auxilios para crear o hacer creer en el pasado. Una página, una página llena de palabras y de signos, hay que recorrerla y ese recorrido se hace siempre ahora [...] Pero la escritura trata de forzar la lectura a crear un pasado, a creer en ese pasado — mientras ese pasado narrado se va hacia el futuro. No quiero que el lector crea en ese futuro, fruto de lo que escribo, sino que lo crea en el pasado que lee [...] Ese momento está escrito en este libro: queda inscrito. (LNI 12) 
Después de plantear que la narración "está siempre en el presente", CI nos advierte: "pero hay que recordar que toda narración es en realidad un flash-back" (la itálica es del autor, 12); para luego condensarlos (pasado y presente) así: "la vida es un prêt-à-porter si pret es una abreviatura de pretérito" (itálicas del autor, 14). O sea, la vida es un pasado continuo que se lleva en el presente. Tal vez otra manera de explicar durée es por medio de la noción de "el momento eterno" que hallamos recurrentemente en LNI —recordar, ¿no es preservar momentos mentales, coexistir, aunque sea ilusoriamente, con el pasado?

Pero, ¿cómo es que la memoria se convierte en durée? En este punto la explicación de Deleuze se hace interesante y compleja. Expone que para Bergson, la recolección no sucede en el cerebro, como si éste fuera un archivo. La recolección se preserva en la durée misma. Cita a Bergson: “[...] la experiencia subjetiva es esa que se nos da en una sustancia cuya esencia es transcurrir [...] prolongando en el presente un pasado indestructible $[\ldots]$ es decir, se preserva a sí misma" (54). Deleuze este proceso lo describe como el aspecto más profundo de la teoría de la memoria en Bergson (55).

Generalmente se piensa que el pasado fue, y que ya no existe. Lo que sucede es que confundimos el ser con el ser-presente. Primero para Bergson, el presente está siempre "deviniendo" por así decirlo "fuera de sí mismo". No es, sino que actúa. Su medio no es ser, sino "lo activo", "lo útil". El pasado ha dejado de actuar, pero no ha cesado de ser. El pasado es inútil, inactivo, "ES en el sentido total de la palabra: es idéntico con el ser en sí mismo (Deleuze 55). El pasado no fue, ya que se preserva en sí mismo en la durée. Deleuze deja claro que lo que Bergson llama "recolección pura" no es una categoría sicológica sino virtual. Es decir, lo psicológico es el presente, mientras que 
el pasado es ontológico: "La recolección pura solo tiene importancia ontológica" (Deleuze 56).

Esta problematización ontológica del pasado es particularmente importante para nuestra tesis. De acuerdo con la interpretación de Deleuze, para Bergson el pasado se percibe en sí mismo, no en nuestro presente. Para estar en el pasado hay que dar una especie de salto ontológico. Es como sentarnos en el cine y mirar una película. Lo que hacemos es penetrar en el ser en sí mismo del pasado. No es posible construir un pasado de presentes; recordar es dar un salto. Dice Deleuze: “Tenemos dos creencias equivocadas $[\ldots]$ que el pasado está hecho después del presente y que es reconstituido por un nuevo presente" (58).

Siempre pensamos en términos del presente pero no nos preguntamos con Bergson: “¿cómo puede existir cada nuevo presente sin que el anterior no ocurra al mismo tiempo de ese que se presenta?" (59). La idea es que no habría pasado de éste no constituirse, primeramente, al mismo tiempo que fue presente. Para Bergson el pasado es contemporáneo con el presente que ha sido: "Si el pasado tuviera que esperar para no ser, si no fuera ahora inmediatamente que pasó, no pudiese nunca haber sido lo que es, nunca podría ser ese pasado" (itálica del autor, 59). Es decir, "el pasado y el presente no son dos momentos sucesivos, sino dos momentos que coexisten" (59). En otras palabras, cada presente pasa en sí mismo como pasado. La duración bergsoneana no es sucesión, sino coexistencia (60).

Resumámoslo. Se ha visto, que para explicar el fenómeno del ser siendo pasado y presente, Bergson se vale de múltiples asociaciones fílmicas. Para Bergson, la memoria se preserva en el transcurrir de la duración, durée, que es esencialmente memoria (Obras 
55). También, vemos que Deleuze parece conectar la idea de la cinta fílmica bergsoneana cuando admite que "la recolección solo se actualiza cuando se hace imagen" (66). La metáfora deleuzeana es precisamente "rotación" de imágenes, lo que nos lleva al movimiento de la cinta fílmica sobre el lente de luz: "Entonces entra no en coalescencia sino en una especie de circuito con el presente" (66). En frecuencia con ambos filósofos, CI anticipa el viaje fílmico que constituye su novela: "Los fotones pueden negar el pasado, pero siempre se proyectan sobre una pantalla —en este caso este libro" (11).

\section{La durée-trama-fílmica}

Se impone un desglosamiento cronológico que permita seguir el recorrido $-\mathrm{O}$ durée bergsoneana, hemos venido a llamar-con tal precisión topográfica de La Habana, en la novela. La trama secuencial, se comprende mejor si la referimos ajustándonos a los datos ofrecidos, que hemos resumido como sigue, a la manera del guión gráfico o storyboard. Lo que nos permitirá comprender hasta qué punto la trama es urbana, desglosada en imágenes fílmicas, detallados fotogramas de calles y lugares, que se hace inminente que tracemos su cronología — casi psicodélica en la superposición de imágenes y la riqueza del detalle, "habanidad de habanidades" ${ }^{, 70}$ ¿No es el cine novela visual?

Refirámonos a un mapa mental de la ciudad trazado aquí:

Plano secuencia: Salen de la revista Carteles (en Avenida Menocal y Peñalver, en Centro Habana), G y su amigo Branly en taxi, para merendar a La Rampa: el taxi no puede entrar por la calle $\mathrm{O}$ y pero sí por Humboldt hasta la calle Infanta, donde se bajan y caminan por O hasta Wakamba: "la cafetería de moda adosada al cine La Rampa" (25). Salen de "la cafetería para subir siete escalones" en vez de por O por la puerta de "el

\footnotetext{
${ }^{70}$ Guillermo Cabrera Infante, La Habana para un infante difunto, página 453.
} 
fondo que da a la rampa interior del cine tautológico llamado — ¿qué otra cosa? — La Rampa" (27). Van Rampa abajo, en dirección al mar, y se tropiezan con Estela que busca una dirección. Plano figura: causa ella gran impresión: "Era una mariposa diurna [...] La mariposa, un efecto alucinante más, hablaba" (30). Continúan su camino, dan la "vuelta buscando Infanta por la calle P" (31), donde toman el taxi que los regrese a Carteles. Pero al llegar a la revista, él decide regresar a buscarla: toma el taxi (un Mercury) hacia Infanta y 23. El tráfico se hace lento en Carlos III; en algún momento cerca de 23 se apea del taxi y echa a correr: la encuentra cuando ella casi se marchaba en un autobús.

Un periodista, casado y pobre, y una adolescente de 15 años se conocen en la calle 23 y la Avenida H, suben a pie, conversando, desde Infanta y 23 por la acera del edificio La Rampa, tuercen al llegar a la calle O, para subir hasta la entrada del Hotel Nacional —ya casi a la hora del crepúsculo: "Entonces llegamos a la entrada del jardín, franqueando el portón como si fuéramos huéspedes" (40). Allí conversan sentados en el césped sobre el promontorio frente al mar. Salen de ahí por la calle $\mathrm{O}$ buscando 23, suben por 23 pasando frente al edificio Alaska, pasando por el costado del edificio Radiocentro: “en la esquina estaba como todas las noches el Artista Cubano" (54) —un músico callejero.

Cruzan 23 para esperar la ruta 32, autobús GM que los llevará hasta "la entrada del camino de Santa Fe” (55), donde vive Estela Morris, en las cercanías del río Quibú. Ya en la casa de ella, a él le da una hambre repentina y sale "cruzando la Avenida de Santa Fe, yendo hacia el picking chicken al otro lado del reparto, caminando las aceras nuevas" (56). Se sintió "alto y fuerte", robustecido, regresando con "dos pollitos". Comen, se besan y se dan cita en la playa de enfrente al día siguiente. Él oye música que 
proviniendo del club "Río Quibú". Toma un autobús en la calzada, ya en la madrugada, para regresar a su casa (luego sabremos que está ubicada en el solar de Zulueta 408).

Al día siguiente toma otra "guagua" hasta Las Playitas (G cuenta aquí que él y su hermano (Sabá Cabrera Infante — hermano del autor— hemos de suponer), recorrían la carretera de Santa Fe para ir a los cines Alcázar, el Majestic, el Verdún): “Ahora la carretera era como un camino de oro a la geometría del amor" (64). Se dirige a la playa de la cita (especie de balneario), y la ve salir como si saliera del mar (65-66). Le dice que la ama y la besa; ella lo abofetea; luego le dice que es menor de edad, retándolo; él le confiesa que es casado. Se disuelve la escena en off o en "un face-out —que quiere decir cierra en negro" (CI, Cine o sardina 154).

Ella lo llama al día siguiente a la revista —él, loco enamorado, acude a la cita esa misma noche en el night-club Quibú (71), ubicado “sobre un pequeño puente, hasta mediado del río que era en realidad un arroyo" (74). Refiere que detrás hay "un cinódromo y que el clamor anunciaba el triunfo de un perro favorito" (77). Van a la casa de ella en el reparto aledaño al río, y en una escena de film noir ella le pide que mate a su madrastra; él sale huyendo, llega a su casa (no refiere dirección pero sabemos luego: Zulueta 408), su mujer duerme y él sueña que mata a la madrastra de Estela —especie de pesadilla donde recrea el crimen.

Al día siguiente (al tercer día de haber conocido a Estelita), desayuna en casa y va con Branly a despedir a su hermano al puerto (quien parte hacia Rusia), van al muelle de La Machina en taxi. De regreso toma otro taxi hasta Carteles; Estela lo llama y se dan cita al día siguiente frente al cine Atlantic (o Astral), calle 23 esquina 10. 
La cita era a las tres de la tarde; ella llega una hora tarde: "Estaba ahí inolvidable" (98), en la misma entrada del "tencén" cerrado. De ahí van en plena tarde del trópico al night-club El Atelier, en la calle 17 y la 10 Avenida. El lugar está a oscuras —a ella le abruma la música—, Peruchín al piano canta "Añorado encuentro", "Total”. Bailan en lo oscuro; ella 1lora, está molesta, contrariada. Plano medio: “- ¿No te interesa la música? — Nunca la oigo" (103).

Ella le dice que ha cumplido 16 años (la mayoría de edad para la época y el lugar) y que se ha fugado de su casa. Salen de allí y él se la lleva a una posada ${ }^{71}$ —lama a su mujer y le dice que la deja por otra (su mujer vive en Zulueta 408, que es la casa/solar familiar en viviera CI durante esos años). La posada queda en un lugar inexacto por los alrededores de su casa, porque G lo ubica así (extraviándolo tal vez en el malabarismo verbal):

Un solar es una casa de inquilinato: el solar de mis mayores. Es otra forma de decir cuartería: más que un cuarto creciente es creciente de cuartos. El solar Zulueta 408 es un ejemplo de falansterio familiar. Tres cuartos de lo mismo ahora reducidos a un cuarto. De la posada considerada como la única casa, el último refugio. (112)

En éste sitio impreciso o híbrido o superpuesto (¿la posada? ¿la casa familiar?) O simplemente una posada en Centro Habana, o en La Habana Vieja (gracias al lenguaje que lo imprecisa), la desvirga en coitos repetidos $(119,128-29)$; salen de la posada a las seis de la mañana (¿a El Vedado? Al final de la calle Línea —véase la página 125),

\footnotetext{
${ }^{71}$ En las palabras propias del autor: "Una posada es un hotel que no es un hotel exactamente. En francés se llama hôtel de passe. No sirve para dar posada al peregrino sino habitación al rijoso y compañía" (LNI 109).
} 
toman un taxi para ir a desayunar en el café, bar, restaurante El Templete, pero está cerrado (a pesar del cartel que dice que está abierto las 24 horas).

Sin rumbo fijo, en plano secuencia, pasan a pie por el pasadizo entre el Club Panamericano y el Floridita y Casa Vasallo (G se presenta como guía turístico del pasado de La Habana), bordeando el parque Alvear o Albear, toman la calle Egido arriba para tal vez desayunar en Campoamor; caminan junto a La Zaragozana con su vitrina llena de mariscos y pescados, antes de cruzar calle Lamparilla, pasan junto a la calle Ariete. En Campoamor, desayunan dos cafés con leche y tostadas. De ahí a La Cuevita, especie de “gruta urbana” refugio de los empleados de Carteles (134).

Para "extender la fuga hasta hacerla un arte" (134) decide ir con ella a Mariel, en taxi; los lleva el mismo taxista depravado que se estaciona diariamente en Carteles. Pasan por la carretera de Santa Fe frente a casa de Estelita, al lado del río Quibú —él decide ahí mismo, en un repentino cambio de parecer, regresar a La Habana Vieja; es el cierre de la revista.

Primero van a La Maravilla, una fonda restaurante, frente a la iglesia del Cristo ya mediodía. Él se encuentra a sus amigos Tony y Junior. Salen de allí: “Estela parecía más Estelita que nunca. Parecía una niña perdida en la ciudad" (141). Toman otro taxi de regreso; ella se queda en la biblioteca, para hacer tiempo, él continúa a Carteles. La recoge luego (nota que no lleva ropa interior), y siguen tramando la fuga en la ciudad: "Era el plano ideal de la fuga: nos estaban permitidas todas las calles" (148). En la encrucijada de las calles Monte y Belascoaín, en "el restaurant [sic] con el nombre apropiado: La Antigua Chiquita" (158) se da cita con Branly.

(Fade-out) 
Han pasado dos noches desde la fuga (él de su mujer, ella de su madrastra), una en la posada, otra en casa de la cuñada de él. Branly lo ayuda a conseguir un cuarto en la casa de huéspedes en la que vive con su madre, en El Vedado, en el extremo sur de la calle Calzada, cruce de la calle O esquina Línea. Allí se cela de Branly.

Camina: Hotel O, Hotel Nacional, Cafetería debajo del cine Radiocentro: toma un café. Rampa abajo, pasa por delante del edificio donde la vio por vez primera: “Ambar Motors: carros caros"-reza un cartel (171), en la esquina la heladería Dutch Cream, allí reflexiona sobre la ciudad: "Esta Creta rodeada de cretinos por todas partes" (172), y ofrece las coordenadas geográficas de La Habana.

Refiere que Estelita pasea por el Malecón en pleno día, “del torreón de san Lázaro hasta el caballo de bronce del Titán epónimo" (172) —que es la estatua a Antonio Maceo. Allí va a su encuentro caminando por E; sentados de espaldas a la ciudad, mirando el mar, él enciende dos cigarrillos para ambos, y conversan sobre situaciones y anécdotas enmarcadas por el litoral habanero.

Para un análisis del mapa de la ciudad — y alarde de la memoria— véanse las páginas 177-178 de LNI. Como un juego de azar vertiéndose sobre el mapa citadino, dice "éramos a la vez los jugadores y el juego", traza el diagrama donde se encontraron para perderse (178):

Con la excepción de los tres viajes a su casa del Quibú y de las breves visitas a La Haban propia no habíamos dejado el barrio que fue un laberinto. No miento. Fue muy poco el tiempo pasó en la biblioteca, mientras esperaba que yo saliera de Carteles para almorzar. Dos fueron los 
viajes, dos: uno a la Avenida del Puerto el día después de la primera noche y luego cuando fuimos a La Maravilla, al borde de La Habana. (178)

Salen a la calle Infanta y ella le pide "Tampax" (179) — lo que denota que ya es mujer.

G dice que se dedicó "no a cuidar mi jardín sino El Jardín, café con terraza de Línea y G” (180). Paseando con Estela da cuenta de los jardines de la ciudad:

Pasamos junto al jardín privado que estaba en la calle 19 casi esquina con A (Ah, A). Después dejamos detrás la iglesia San Juan de Letrán. Estelita no se interesaba por iglesias ni jardines. Pero, me dijo, había estado esperando el primer día para escapar al sol junto a los jardines comerciales de Zapata, donde había fresco. Allí los jardines tenían nombres: El Gladiolo, La Diadema, La Dalia, La Hortensia [...] Goyanes y Trías [...] Se agolpaban hacia Zapata frente al cementerio. (180)

Pasan frente a la casa (con jardín) de Martha Frayde — disidente de la Revolución, la célebre Dra. Frayde, fue prisionera política, y exiliada - no ofrece la dirección.

\section{(Fade-out)}

La encargada de la casa de huéspedes le avisa que Estelita sale con Branly/Robertico, incluso sugiere que también con alguien más. Él decide dejar la casa de huéspedes, "vender el sofá" (188), en lugar de renunciar a su amante inconstante (Viene aquí escena que es un calco del cine, del filme Un tranvía llamado deseo (1951) clásico del cine norteamericano, dirigido por Elia Kazan, basado en la obra de Tennessee Williams).

Van a vivir al hotel Trotcha en medio del Vedado, habitación 7, donde él dice que son "hermanos". El Trotcha lo refiere aquí desde el presente narrativo, como hotel. Pero 
cuenta que había sido primero un teatro: "era, todavía, un escenario. A los jardines se le había añadido no poca rocalla para un diseño rococó, que contrastaba con la galería abierta toda blanca" (194). Luego fue un balneario de lujo a finales del siglo XIX: El edifico todo blanco, todo de madera, pasó a formar parte de mi mitología: No era su esplendor (que ocurrió en el siglo pasado) sino su decadencia lo que me fascinaba $[\ldots]$ un edifico no puede ser una metáfora. Eso se llama la consolación por la prosopopeya. (200)

\section{(Fade-out)}

Yendo cierta vez para el Trotcha describe el recorrido: "evitando las luces del Carmelo, por la acera del Auditórium" (195); ella lo espera en el lobby del hotel, salen a Calzada y se encuentran con un poeta amigo de $\mathrm{G}$-ella desprecia la poesía de éste.

Él llega un día al Trotcha y hay un hombre con ella en la habitación: “¿Te acuerdas de mi tío? [...] Hay en los celos un sexo, sexto sentido que nos hace penetrar la trama más espesa $[\ldots]$ pero era obvio que me estaba engañando, que era falsa y traicionera" (206). La escena se esfuma en reflexiones existencialistas; la trama cronológica se discontinúa.

(Fade-out)

Sale G de Carteles y decide ir a ver Branly en la casa de huéspedes de Línea refiere la historia de la calle:

A propósito de Línea, se llama Línea por la línea del tranvía [...] Al terminar la calle Línea el tranvía continuaba para dar la vuelta al promontorio donde está el Hotel Nacional. Por allí rodaba incólume por esa escarpa Mutia y salía, indemne, a la calle Infanta, dejando ver el 
Malecón y el mar. En las noches de luna, el tranvía viajaba, breve, por entre un paisaje encantado. (208-209)

Pero Branly está ingresado en el Hospital Calixto García, producto de una dolencia: parafimosis (ocurre cuando el prepucio de un varón incircunciso no se estira).

Entonces el relato se torna reflexivo; el topos deviene sentimental: "Durante el tiempo que duró su aventura y mi ventura, ella estuvo virtualmente secuestrada por mí” (218). Por la noche caminaban, cuenta: "Yendo a veces por Calzada arriba, otras veces por Línea hasta Malecón.” (219). Parece el fin del amor, en su banalidad, se deshizo del hechizo de Estelita (ver 221). Como analogía prousteana y paradójica, el narrador enferma de "un catarro malo que vino a salvarme"; el amor por Estela será como "un catarro de verano que pasa con el verano" (217). Agripado de mala fe, reitera la idea del amor como una enfermedad: "Soy un enfermo que camina por un sueño [...] Ella es mi Everest y a la vez mi Neverest. — Tenemos la vida por delante -dije yo. — Lo que tenemos es la muerte por delante — dijo ella, siempre sombría" (227-28).

Regresa a vivir con su mujer (en cuartería o solar de Zulueta 408), y visita a Estelita. Cierta vez parecen citarse en una posada — descrita como tal (inferimos que para darle un tamiz fílmico a la escena), pero que termina siendo la habitación 7 del Trotcha (243): "En un final, como canta el bolero, la barca tiene que partir. Voy a navegar por otros mares de locura" (245) (el señalamiento es del autor).

Llama al final amoroso "Titanic sentimental", describiéndolo como la trama de un filme de suspenso:

Titanic sentimental, estaba, precisamente destinada a hundirse. Por los altoparlantes venía una orden perentoria $<<$ Abandon ship! Abandon 
ship!>>. Ya escoramos a babor, a popa sólo quedaba el recuerdo. Abandon

her. (Todo barco, buque o bote es en inglés femenino.) Abandonarla.

Sálvese quien pueda. Abandon her now! Ella se veía abandonada en la cama entre almohadones baratos. (245)

Plano medio corto: Saliendo de la habitación, nota que ella tiene una pequeña navaja en la mesa de noche. La deja y se va al cine Rodi (Línea y A, en el Vedado), a ver el filme norteamericano Designios de mujer (1957), de Vicente Minnelli, va cruzando Calzada, atravesando Línea.

\section{(Fade-out)}

Transcurre un lapso de tiempo indefinido. Junior, un amigo robusto, se cita con él en el restaurante El Carmelo (Calzada y D), y le confiesa que vive con Estelita (247). Un tiempo después, toma un taxi al café Vienés (Avenida de los Presidentes (o Avenida G): "porque no hay combinaciones fáciles desde mi casa a la calle Línea" (260); allí se la encuentra por casualidad y se van en otro taxi (261). Ahí, dentro del taxi, ella le confiesa: "Me estoy acostando con tu hermano" (262). También, en tono de burla le dice: "Que no me falta más que tu padre" (265). La femme fatale es arma letal para el ánimo del narrador: "Fue entonces, más allá de la 12, yendo a acostarme con ella, que decidí que no quería acostarme con ella. O mejor, que no debía” (265), regresándola al café Vienés (Avenida G y la calle ¿23?).

La antepenúltima vez que la vio él iba en un taxi; la recogió cuando ella bajaba caminando por Línea rumbo al teatro Trianón. Caminaron hasta F: "Vivo aquí [...] bueno, el caso es que ahora soy lesbiana" (267) — le dice señalando para un edificio "feo". Estelita es la mantenida de otra mujer — antigua compañera de estudios de él. 
La vuelve a verla un par de veces más. Primero en el mismo café Vienésfrecuentado por homosexuales — vestida masculinamente y acompañada por otra mujer. Primerísimo primer plano: "Estela esa tarde, era hembra entre hembras [...] La vi como no volvería a verla jamás. La consumí con mis ojos. Consumí, consomé: extraer la sustancia de una carne comestible" (272). Luego la vuelve a ver $\multimap$ la intuye de manera fílmica, casi onírica, en el Picasso (en la calle12 y la Avenida ¿?), un night-club de lesbianas (275-77):

Debajo del vestido rojo tenía un refajo negro, breve, que apenas le cubría el pecho y no le llegaba a los muslos. Sospechaba que ella era el sexo que huye, que te devora, pero su rostro era apacible, desapacible, apacible de nuevo y de veras inerte, indiferente. Ella ha viajado, se ha ajado. Pero ¿ha vivido? Parecía un zombi blanco: mi versión de Christine Gordon caminando catatónica en la noche haitiana ${ }^{72}$. ¿Qué sería de mí sin el cine? (277)

A partir de que languidezca el amor, la novela se disuelve como bajo el efecto fílmico de sfumato, como "un catarro de verano", y el topos urbano también, cuerpociudad que han sido la misma cosa. Restan una reflexión de dos cuartillas sobre Estelita, y una escena de una cuartilla donde él mismo, sentado frente al televisor con su mujer inserta un bolero nostálgico. Concluye con una cavilación a dos tiempos: el presente del escritor, y el pasado del desamor veraniego donde, en una cuerda amorosa él se dirige a Estela con una referencia topográfica: "Pero quizás estas páginas te reconstruyan como si fuera un palimpsesto pal incesto [sic]. Ah, Estelita, ¿por qué me persigues?” (283).

\footnotetext{
${ }^{72}$ Referencia del filme norteamericano I Walked with a Zombie (1943), dirigida por Jacques Tourneur.
} 
Parece decir que, sobre el mapa de la ciudad, andándola, en autobús, y sobre todo en taxi —ual sobre tabula rasa- se escribe esta historia.

\section{Submodalidad taxi-del-tiempo}

La idea de esta submodalidad no es para nada gratuita. El propio narrador la ofrece cuando busca a Estelita en el recuerdo a bordo de un taxi, en una imagen del reverie cuajada de asociaciones oníricas:

Tuve que vadear las aguas del Leteo, río del olvido, laberinto lábil, para encontrarte de nuevo. Caronte, que ya no trabajaba en el puente sobre el río Almendares sino que limpiaba por una peseta el cristal que había nublado el salitre del Malecón, me dejó verte. Fue a través de otro parabrisas, esta vez de un taxi, que te volví a ver. (19)

Si nos dejamos llevar por la metáfora del taxi que nos conduzca a través de la memoria de CI, abordaremos con el protagonista once taxis $-\mathrm{o}$ autos de alquiler - para una alegoría del viaje en el tiempo: "mi relación con el taxi o con los taxis es larga y fructífera" (34), dice.

En taxi se recorrerá la ciudad — sobre todo el tramo que va desde la sede de la revista Carteles a La Rampa, y por el área de El Vedado:

— Nadie en Cuba dice taxi. Dicen máquina de alquiler y se acabó. Pero tú los llamas taxis. ¿Dónde crees que estás, en una película? Eres un pretencioso — dijo Estelita.

- Di mejor que soy un preciso.

— Un preciosista —dijo Branly.

- Pero un taxi siempre será un taxi. 
— Lo que te hace un taxidermista.

— Taxi viene de taxímetro pero no hay un solo taxi con taxímetro en La Habana.” (161)

Como en las películas, dentro de un taxi suceden diálogos clave: "la prodigiosa y larga conversación que cabe en un taxi” (262). Gracias a un taxi se resuelven escapadas y traslados, escenas definitorias para la trama sentimental de esta novela.

Este será el segundo viaje en el taxi del tiempo: “Abrí la puerta del taxi. Branly siempre me decía que iba a encontrarme con el diablo en un taxi” — anticipando una secuencia fatal, mientras aborda el auto de alquiler que lo lleva al encuentro con la aún desconocida Estela: "a mi cita que no era una cita todavía" (33). Aunque se presenta como un taxi distinto al primero que abordáramos — referido arriba— la descripción del chofer tiene pinceladas surrealistas:

El diablo estaba ya adentro $[\ldots]$ la obscenidad al volante $[\ldots]$ su cara era su alma $[\ldots]$ casi se lamía los labios, gruesos y rojos salientes de su cabeza obesa $[\ldots]$ los ojos púrpura y escarlata. Era un cuerpo trocado en cabeza, como si lo hubiera decapitado una guillotina moral. (32-33)

El sujeto descrito aquí, chofer de taxi que se estaciona en Carteles, es el que conducirá el vehículo que aborda el protagonista en más de una ocasión. En la novela, el discurrir de la vida, es equidistante a un viaje en carretera: "Ahora la nueva carretera era como un camino de oro a la geometría del amor" (64).

Para adentrarnos en la ciudad a bordo esta máquina del tiempo que convoca CI, sugerimos la idea del reverie bachelardeano. Hemos visto, en nuestra introducción y el Capítulo I de este estudio, cómo la experiencia humana para Gaston Bachelard conlleva 
un potencial extrafísico, que tiene que ver con la manera en que percibimos el espacio (lo que referimos como espacio ontológico), yendo más allá del espacio físico. Para Bachelard el espacio no es necesariamente un contenedor de objetos tridimensionales (lo que referimos como espacio físico), tampoco es el análisis de la arquitectura o el diseño urbano (aún importantes para la comprensión del espacio citadino), sino que se refiere a lo que él califica como el adobe de la conciencia humana. Es decir, el espacio ontológico es una producción de la conciencia. En este caso contenedor de entidades y relaciones, que pueden o no ser físicas ${ }^{73}$. Más importante aún, Bachelard quiere acomodar en este espacio la conciencia del "soñador despierto" que él llama reverie.

En LNI el espacio ontológico está dado en una relación estrecha con el espacio físico de la ciudad. Pero el vehículo (no pasemos por alto la connotación del vocablo en el contexto de esta submodalidad) para acceder este espacio es la memoria (que viaja en taxi), supeditada ésta a la intencionalidad:

Cogí un taxi en la esquina porque no hay combinaciones fáciles desde mi casa a la calle Línea.

— ¿Adónde? — preguntó el chofer.

No le oí y volvió a preguntar:

— ¿Adónde quieren ir?

— Al pasado —le dije. (LNI 260)

El ser se proyecta en el pasado, reverie "eflorescente" que "reververa" (Casey

287). Es un espacio mental-fisico, accedido a través de la memoria, para crear un

\footnotetext{
${ }^{73} \mathrm{El}$ espacio ontológico puede contener una variedad indeterminada de situaciones. Por ejemplo, puede imaginarse el espacio topográfico de La Habana tal cual es, o un espacio paralelo, de calles no existentes de La Habana (o una ciudad hipotética). Está claro que toda situación ocurre en un lugar. Es entonces que podemos entender que LNI, en tanto que totalidad de situaciones imaginarias, ocurre en un espacio.
} 
presente narrativo, siempre revisado, editado, metaficticio, reflexionado por el sujeto que lo re-crea: "La literatura es más importante que la vida" (LNI 237) —o sea, la creación, el reverie, el viaje en taxi por la ciudad en la memoria (memoria como factura, producto mental de G). Así explica $\mathrm{G}$ el proceso (en la cita anterior y en la que sigue, las itálicas son nuestras):

El pasado es esa tierra inmóvil a la que nos acercamos con un movimiento uniformemente acelerado, pero el trayecto — tiempo en el espacio- nos impide apartarnos para tener una visión que no esté afectada por la caída —espacio en el tiempo — voluntaria o involuntaria. El tiempo, aun detenido, da vértigo, que es una sensación que sólo puede dar el espacio.

\section{(LNI 18)}

Del fragmento anterior sólo queda sin explicarse la caída, que sin embargo nos remite a La caída (1956) de Albert Camus, y al ánimo existencialista que ya abordamos. El flâneur ${ }^{74}$, recorriendo las arterias de la ciudad: "Habana, que hace a los hombres y los gasta” (172), evoca una dimensión de geógrafo ${ }^{75}$ : "la disposición de las calles es, al revés del laberinto, en extremo fácil” (177).

La novela anticipa ese "vacío de sinlugaridad" que Samuel Todes anota, dado además por la impermanencia del cuerpo físico: "De modo que el 'vacío de impermanencia' anticipa el posible 'vacío de lo no ocupable"” (Todes 57) que es el

\footnotetext{
${ }^{74}$ Del francés flâneur, el hombre que camina la ciudad para experimentarla. Es también el hombre en la multitud de la ciudad moderna.

${ }^{75}$ Bachelard apunta: "Incluso, cuando un poeta evoca una dimensión de geógrafo, sabe por instinto que esa dimensión se lee en lo inmóvil porque está enraizada en un valor onírico particular" (PDE 224). Esta proyección de "valor onírico", o obnubilado es en término bachelardeano el reverie. En LNI encontramos un exceso de detalles topográficos.
} 
sinlugar. Inferimos que este "vacío de sinlugaridad" provocado por el exilio, a instancias "el exilio invisible", acuñado así por el propio CI en un artículo homónimo publicado en 1985 (véase la referencia bibliográfica), deviene una marcada vocación de reconstruir el mapa de la ciudad, recuperar el detalle pedestre y vehicular, transcribiéndolo como si de una pantalla de cine se tratara, logrando transmitir coloquialmente la inmediatez del que observa y descubre a un mismo tiempo: "Al final de la calle Línea estaban levantando, habían levantado, los raíles y se hizo difícil cruzar. Parecía que estaban cavando trincheras para una guerra futura, era una guerra al pasado" (125).

Ciertamente, la ciudad se presenta inventariada, donde cada calle, cada recodo, vuelve una y otra vez a ubicarse en el recuerdo: "Una virtud que tiene mi historia es que de veras ocurrió" (11). Recuperando así la experiencia del cuerpo en el espacio citadino, ciudad cual bosque de la modernidad extraviado en el destierro y en la memoria cuajada de olvidos: "No recuerdo otra salida del perímetro que va de la calle O donde la conocí, hasta el Almendares, que se llamaba, se llama todavía, El Vedado" (177).

Pero en la memoria, también se forja una fijación geométrica arbitraria: dentro de la memoria, una memoria inventada, ¿cómo entender si no el siguiente juego semántico?: "Ella rechazaba no tácitamente, que implica consentir, sino de pleno ser un personaje, tanto como yo me empeño ahora en hacer su personaje" (218). Prueba es que la memoria referida aquí no reconoce olvidos. Tanto así que da cuenta de los olores — de la memoria, ¿meticulosidad ésta hija de la ansiedad que produce el "vacío de sinlugaridad" abordado por Todes? Cabe la pregunta cenestésica bachelardeana, ¿a qué huele la ciudad?76: "El

\footnotetext{
${ }^{76}$ Para completar la imagen, Bachelard se pregunta también: “¿Cómo ver sin oír?” (PDE 216).
} 
Vedado olía a limpio temprano en la mañana. Lo que no era tan sorprendente porque era temprano en la mañana. Ella olía a limpio, yo olía también a limpio. Todo olía a limpio y no a semen y a sangre derramada. El rocío limpia y lava" (LNI 124-25).

En La poética del espacio (1958) Bachelard reúne imágenes — dándole a las imágenes su valor ontológico - para explicar una dialéctica de lo interno y de lo externo, de lo abierto y de lo cerrado (31). Bachelard se refiere al bosque interior que habitamos ${ }^{77}$, o cuando alude los rincones de las casas que alocamos (casas que hemos vivido o que hemos experimentado), o los nidos como metáforas de casa y refugio, o las conchas (casa del caracol) que el ser lleva a cuestas (30). La ciudad, se ha dicho, es el bosque de la modernidad. Esa valuación da G a La Habana, su bosque ancestral, sus esquinas, su casa/nido/concha/isla a cuestas, paradigma acentuado por la condición de exiliado ${ }^{78}$.

El personaje que nos narra en primera persona es una especie de proto-turista en la ciudad "encantada" (un explorador que curiosamente viene del futuro, que es el presente narrativo), reflexivo por demás: "El pasado sólo se hace viable a través de un presente ficticio" (18). Es el flâneur en cuanto a que está distanciado, aún inmerso en su circunstancia, circundado por la ciudad en la memoria:

La memoria es otro laberinto en que se entra y a veces no se sale. Pero son fantásticos, innumerables los corredores de la memoria, fuera de la que

\footnotetext{
${ }^{77}$ Bachelard cita un verso de Jules Supervielle: "Habitantes delicados de los bosques de nosotros mismos", para explicar que el bosque ancestral que evoca el poeta, que es el mismo de los cuentos infantiles, está enrizado "con-nosotros" y "reina en el antecedente", en la experiencia personal que nos vincula al bosque real y al metafórico (PDE 224-26).

${ }^{78}$ El "bosque ancestral" como metáfora del lugar a donde ocurre o se dirige el reverie o ensueño. La universalidad del bosque pleno que ocupa a poetas y que abunda en los cuentos infantiles, Bachelard lo hace propio al conectarlo con el bosque más próximo en el que se perdiera su abuelo "en un antaño en el que yo no vivía" (PDE 226), pero que no por ello le es ajeno. Debemos agregar que el "claro del bosque" de Heidegger, aquél que contiene la verdad artística, es retomado por Bachelard cuando habla del "bosque ancestral".
} 
hay un solo tiempo real y es aquel que se recuerda -es decir, yo mismo ahora en que la máquina de escribir es la verdadera máquina del tiempo. (la itálica es nuestra) (LNI 18-19)

Conmueve constatar que la meticulosidad en describir y completar la imagen de la ciudad yace sobre una carencia, sobre la ausencia del espacio físico-temporal perdido. Dice Walter Benjamin: "Hasta la reproducción de arte más perfecta carece de un elemento: su presencia en tiempo y espacio, su existencia única en el lugar que ocurrió" (Illuminations 220); CI sabe que se apoya en una estructura frágil.

LNI se sostiene/edifica encima de una pérdida; ya desde el principio se adelanta este propósito de recuperar el pasado ${ }^{79}$. Veamos cómo en el prólogo hallamos algunas claves que ayudan a ubicar el espacio ontológico cabrerainfanteano:

Según la física cuántica se puede abolir el pasado o, peor todavía, cambiarlo. No me interesa eliminar y mucho menos cambiar mi pasado. Lo que necesito es una máquina del tiempo para vivirlo de nuevo. Esa máquina es la memoria. Gracias a ella puedo volver a ese tiempo infeliz, feliz a veces. Pero, para suerte o desgracia, sólo puedo vivirlo en una dimensión, la del recuerdo. (LNI 11)

Recordar es como una máquina del tiempo (la itálica es nuestra), dice $\mathrm{G}$, un taxi que lo transporte allí. Primeramente, el narrador rechaza la cualidad moldeable, la subjetividad de la memoria, para después, desde la analogía de ésta como una máquina del tiempo que lo transporte al topos, revivir la experiencia; pregunta Estela: “— ¿Cuál

\footnotetext{
${ }^{79}$ Nos referimos a la intencionalidad que acunara la fenomenología bachelardeana. Véase el Capítulo I de nuestro estudio.
} 
tranvía? Ya no hay tranvías”, responde él: “- Pero queda el recuerdo. Si oyes lo bastante los oirás chirriar sobre las líneas y el chasquido del trole arriba" (50).

G se embarca entonces en una especie de juego con el lector y con su propia memoria de los hechos (y de la memoria inventada), a ratos apelando a lo testimonial, a una verosimilitud que se nos antoja tramposa, ilusión de atrapar el pasado, dentro de la ilusión fílmica:

Siempre he admirado en Cary Grant no su estatura sino su habilidad para encontrar un taxi vacío y cogerlo. North by Northwest ${ }^{80}$ es más que nada un desfile de taxis: para cogerlos, a punto de cogerlos y cogiéndolos. La parataxis, como en El difunto Matías Pascal [sic], era mi recurso retórico. (208)

No se pase por alto que la figura retórica defiende la arbitrariedad de ciertas asociaciones inconexas, ¿parar taxis no va en pos entonces de conectarse en la ciudad? También el vehículo de la huida de los amantes, él huye de su mujer, ella huye de su madrastra, y ambos de la ley —ella es menor: "Decidí extender la fuga hasta hacerla un arte. Alquilé el taxi para ir al Mariel. ¿A que no adivinan quién era el chofer? Nada menos que nuestro delincuente desconocido, el plantado en Carteles" (134).

A ratos también, abiertamente trasgrediendo la ficción, enseña la costura del deseo, la voluntad creativa, la evidencia, a manera de corregir, editar, como en el cine, la memoria experiencial. Lo que nos lleva a comprender la proyección del ser es una proyección fílmica, cuya dinámica resulta cómicamente aparatosa: en "la máquina del tiempo", que aterriza en la pantalla-filme de este verano azaroso.

\footnotetext{
${ }^{80}$ Se refiere al filme norteamericano de Alfred Hitchcock, circa 1959.
} 
Pero constatemos que para CI la novela es pantalla-libro donde se proyecta la historia — esto dice refriéndose a Estelita:

El intangible conocimiento (todo lo que sé de ella) puede cambiar algo tan concreto como el pasado en que ella vivió. Una canción contemporánea parece decirlo mejor que yo: “Cuando el inmóvil objeto que soy / encuentra esa fuerza irresistible que es ella”. Los fotones pueden negar el pasado, pero siempre se proyectan sobre una pantalla — en este caso este libro. La única virtud que tiene esta historia es que de veras ocurrió. (11)

Entonces nos adentramos en el recuerdo del narrador, que es la novela como la imagen fílmica — técnica afín a la manera en que recordamos. CI consciente de ello muestra las hechuras:

Habrá momentos en que el ojo que lee no creerá lo que ve. Eso se llama ficción. Pero es necesario siempre que el lector confunda el presente de la lectura con el pasado de lo narrado y que ambos tiempos avancen en busca de un futuro que es la culminación de la acción en la narración [...] Pero hay que recordar que toda narración es en realidad un flash-back. (12)

Nótese la distinción en itálica del propio autor en realidad; lo que denota que se plantea la novela como experimento (im)puramente (permitámonos la valla del paréntesis) literario, una cinta fílmica editada: "La verdad es suficiente invención” (LNI 20) — remitiéndonos una vez más a la intencionalidad a la que se somete la otrora realidad de los hechos. Lo que cuenta es acomodar al ser en una realidad retroactiva, en la durée bergsoneana. 
Pero G se observa desde el futuro (que es el presente de la escritura) en el pasado (la acción), a bordo del taxi-del-tiempo, reconoce con pesimismo sartreano la negligencia que implica la fuga — en cuanto a que el existencialismo sartreano es una fenomenología aplicada al análisis de la existencia: "Pero era demasiado tarde para el ser y demasiado temprano para la nada" (126) (la itálica es nuestra) ${ }^{81}$. Los amantes de esta historia regresan de la huida sin rumbo fijo, en el mismo taxi, girando de regreso a El Vedado.

\section{Submodalidad banda-sonora}

La duración de este preámbulo amoroso de apenas un verano, tiene su música de fondo, su foley. Esta nostalgia tiene el tamiz de un bolero: "Si yo pudiera escribir boleros, no me importaría no escribir libros" (102). Pero es que CI escribe la novela como si escribiera un bolero. El componente trágico y sentimental del bolero viene como anillo al dedo a la historia: "Hay preguntas que suenan como boleros. Lo que no es grave. Lo grave es cuando también las respuestas suenan como boleros" (51). Sin embargo, elabora diálogos con textos de boleros y lo hace notar al lector — dando lugar a que el propio lenguaje nos plantee una casi obsesiva partitura ventrílocua: “-Quiero estar contigo. Sólo faltaba decir mi bien para completar otro verso de boleros" (52).

La cinta fílmica de la memoria cabrerainfanteana tiene una impecable banda sonora; G recuerda con música de fondo— cuando no de protagonista:

— ¿Cómo se llama ese son?

- Es un bolero.

— ¿Qué se llama?

— $<<$ Piano $>>$ Es un bolero con el piano como protagonista. Y dice así:

\footnotetext{
${ }^{81}$ No se nos escape la alusión a El ser y la nada (1943), de Jean-Paul Sartre.
} 
Piano que acompañas mi tristeza. (75)

La música incidental aparece en LNI en escenas fílmicas en la memoria resume la historia: "Hay un bolero que toca Peruchín que se llama $<<$ Añorado encuentro $>>$ y eso es lo que fue. Curiosas las canciones cómo dictan los recuerdos" (21). El mismo bolerista aparecerá en la visita que hacen los protagonistas a El Atelier, donde también Peruchín tocará y cantará éste y otro bolero melancólico "Total". Ambos temas enmarcan la relación entre ambos: el primero anuncia un encuentro amoroso; el segundo presagia una traición de una de las partes.

Hasta tal punto G recuerda en imágenes fílmicas que las explica y recrea cual cinematógrafo. Traigamos el siguiente ejemplo: Cuando G se encuentra en caférestaurante El Carmelo con Junior -quien será su archienemigo, conquistando a Estela poco después que ésta y $\mathrm{G}$ hubieran roto — lo describe así, comparándolo con Bill Bendix el actor: (Junior) "era bondadoso, amistoso pero potencialmente peligroso cuando la orquesta Mantovani, que se encargaba de la música indirecta en su cerebro, tocaba su canción —Monkey music" (252). El lector sin duda percibe el peligro potencial de la escena, sinestésicamente enriquecida por la referencia sonora, cuando Junior le confiesa que se ha unido a Estela (254).

La última vez que ve a Estelita en el night-club Picasso, ella baila "con su pareja que era difícil decir si era hembra, hombre o sombra" (277). Como en el cine, G se apoya en la música para transmitir las atmósferas, la letra de una canción para describir sentimientos:

Al fondo, detrás de donde habría estado la orquesta, había una vitrola $[\ldots]$ El rock'n'roll había tomado La Habana por asalto [...] 
del tocadiscos venía una música melosa que no era rock'n'roll sino rhythm and blues. Los Platters cantaban desde el disco. Sabía que la canción se llamaba, impuesta pero opósita [sic], Only You. (276-77)

Dondequiera hay una referencia musical en la novela, tanto como "dondequiera hay un piano en un rincón de esta ciudad" (75). Bachelard dice que "todo soñador solitario sabe que oye de otro modo cuando cierra los ojos [...] para reflexionar, para escuchar la voz interior, para escribir la frase central” (PDE 218), y el reverie cabrerainfanteano tiene su banda sonora, su datación musical impecable.

Hemos podido identificar las siguientes referencias musicales (ténganse en cuenta que han de escapársenos varias aliteraciones y juegos verbales, sin duda): 21, 25, 30 y 45 (ocasiones donde explica que Estela tiene voz de tiple, especie de guitarra pequeña), 47, $51-52,54,66,102,105,122,131,132,137,138-39,140,165-166,167,181,195-98$ (conversación con un músico), 201, 203, 215, 238, 275-77. Este recurso es sin duda filmico, tan marcado que solo puede servir de apoyo a nuestra tesis.

\section{Modalidad ciudad-fílmica}

Hemos tratado de demostrar una definición de la memoria que se apoya en paralelos con la técnica cinematográfica: "He vuelto a recorrer La Rampa anoche. No era un sueño, era algo más recurrente: el recuerdo" (21). Como en el cuarto oscuro del revelado, nos hemos servido de un par de lugares comunes para abordar la memoria como un contrapunto entre oscuridad del olvido y luz del recuerdo.

La ciudad entonces se afinca como el topos de la intencionalidad bachelardeana, cuando en el mismo prólogo de LNI se ofrece esta inquietante confesión: “Aunque parezca una declaración asombrosa, que no quiero que sea, La Habana no existía 
entonces" (13). Se desprende de la cita que La Habana de esta historia, surgió después, como artilugio de la memoria y en la literatura, plausiblemente porque fue más tarde en la vida del autor/protagonista que se coloca allí, se auto-observa: el espacio circundante de estos amantes existe en cuanto a que es cinta fílmica de la memoria (sea o no memoria inventada). La ciudad recordada y vuelta a andar de CI es una ciudad presentada como cine.

Permitámonos trazar un paralelo entre la novela que nos ocupa y el cortometraje P.M. (1960), en virtud de un parentesco entre ambos ${ }^{82}$. Filmado en la sacudida social de 1960, el cortometraje de Sabá Cabrera Infante (hermano de Guillermo) y Orlando Jiménez Leal, aún vibra como alternativa al arte comprometido. El corto que apenas dura 25 minutos, se hace en medio del conflicto bélico y la militarización popular que a partir de ese momento caracterizaría a la sociedad cubana hasta hoy. No obstante, el modesto documental filmado al estilo del free cinema — tal cual LNI — no alude nada del acontecer político. Sus detractores de entonces no pasaron por alto que la omisión ya era un acto de rebeldía (digamos, de libertad artística), convirtiéndolo en documental político. Y ahí es donde gravita el meollo de la censura que le impusieron al cortometraje. ¿Que si la censura impuesta al filme ventilaba rencillas personales entre cineastas y dirigentes como Alfredo Guevara? Lo que no resta importancia a la repercusión política de la reprimenda: el cierre del periódico Lunes que dirigía CI, y el célebre discurso de Castro donde dejaba claro el corte estalinista de su régimen.

\footnotetext{
${ }^{82}$ Sobre la participación de CI en el proyecto del filme de su hermano y Jiménez Leal (además de los hechos que le subsiguientes), dice Emma Álvarez-Tabío Albo: [...] P.M., un ensayo de free-cinema realizado por Orlando Jiménez (n. 1941) y Sabá Cabrera (n. 1933), hermano de Cabrera Infante, quien lo patrocinó a través de la revista Lunes de Revolución" (375) (la itálica intermedia es nuestra).
} 
El valor de P.M. estriba en que capta la belleza azarosa de la noche habanera, manteniéndose prácticamente intacta a pesar de la crisis de los misiles y de los grandes cambios socio-políticos. En P.M. una idiosincrasia detenida discurre ante los ojos, despertando cierta nostalgia por una atmósfera que se perdía con el nuevo paradigma sociopolítico. Una Habana desaparecía para siempre. El lente aleatorio no pretende más que recoger un pedazo de esas vidas de obreros que salen de noche a beber y a bailar, a sabrosearse. Ahí está el carácter nacional, que quizá no es el que deseamos ver; mucho menos el que se proponían proyectar los detractores del cortometraje: la imagen del "hombre nuevo" y las jovencitas alfabetizadoras insertadas en la manigua. Ahí está el jolgorio marginal de los trabajadores del puerto y sus familias, donde nada es fingido para la cámara, donde queda expuesta la alegría infeliz de las gentes, incluso, el candor de sus lasitudes. Mientras una nación había de sentir o fingir compromiso con el proceso revolucionario y el arte debía fungir como propaganda, P.M. observa al desnudo la decadencia de una noche casual, sin atavismos, pose, ni ( $¡$ ah pecado!) compromiso. Salvando un breve lapso de tiempo, la novela que nos ocupa incurre en las mismas exclusiones de lo político y el mismo regodeo crepuscular urbano que P.M., la primera en El Vedado, el segundo en área del puerto. En LNI confluye el amor por la noche - como cuarto oscuro de revelado de la ciudad - la trama da cuenta de trivialidades, cual lente de cámara que capta las vidas de los sin nombre, al margen de las voces estridentes de la historia. CI, o simplemente G, se considera el cronista de la intrahistoria: "El cronista había triunfado sobre su amante esa noche lluviosa de mediados 
de agosto" (216). Novela y filme son estéticamente compatibles: dubitativos, displicentes, incontaminados de lo político, noctámbulos, reos inocentes ${ }^{83}$.

La ciudad nocturna se hace credo en LNI; así conversan los amantes mientras pasean la ciudad:

— ¿No me crees? ¿En qué crees entonces?

— En nada.

- ¿En nada en nada?

— En todo caso no en mí. ¿Y tú?

— Creo en esta calle, en este barrio, en El Vedado, en La Habana, en el mar, en la corriente del Golfo, en el trópico. También creo en ti.

— ¿Me estás corriendo una máquina?

— En lo absoluto. Creo en ti como creo en la ciudad y en la noche. (182)

Ávido sorteador de arquetipos, CI trae constantemente al texto lugares comunes dispersos en la nocturnidad de La Habana: "noche que se desmaya sobre La Habana, noche tropical” (42). Por eso llegan los ecos martianos en concurrencia de imágenes de film noir: "Ambulaba noctívago muchas veces mientras abría las puertas de la noche" (44). La ciudad de noche, fluida y titilante, propicia imágenes: "Era una noche sofocada por la luna $[\ldots]$ La luna es un afrodisíaco ambulante, cité al verla sobre las irreales torres del hotel convertidas por el pálido fuego de su luz, torres del Ilium ${ }^{84,}(44)$ —son las imágenes de un ciudad perdida.

\footnotetext{
${ }^{83}$ La versión de CI sobre los célebres hechos la hallamos en Mea Cuba, páginas 61-86. Aquí tomamos prestado del autor cuando, refiriéndose a P.M., dice: "no haya habido reo más inocente en la historia de las relaciones entre el Gobierno Revolucionario cubano y la cultura del país" (Mea Cuba, 62).

${ }^{84}$ Cita y parafrasea el poema "The Garret”, de Ezra Pound. Ilium es la parte superior de la pelvis.
} 
La ciudad es presentada una y otra vez como material fílmico. Veamos como ejemplo la siguiente escena, que se desarrolla en El Vedado, frente a la casa de huéspedes donde los amantes fugitivos vivirán por un tiempo. Pero este espacio se trasmuta en la imagen cinematográfica de Un tranvía llamado deseo (1951). La simería entre Stanley Kowalski y Stella en el filme, y G y Estelita en la novela radica en la relación de poder que ambos hombres ejercen sobre ellas. El ardid consiste en traer con la referencia filmica una emoción paralela, evidenciando la potestad de la intencionalidad sobre la memoria —recuerdo éste que pudo haber sido, digamos, dramáticamente menos afectado, y que por obra de la voluntad es un calco cinematográfico (no se pase por alto la simetría de los personajes fílmicos con los de la novela):

Regresé a la calle y miré a la fachada, ahora un dibujo de Chas Adams. De pronto, sin darme cuenta, me salió un grito por la boca apretada:

- ¡Estela!

Nadie me respondió.

- ¡Estela!

Y di un grito mayor:

- ¡Estela!

Al fondo y por la puerta abierta se encendió una luz. (189)

CI reubica la escena clásica, en la ciudad escogida. Para la proyección del espacio ontológico (nótese la coincidencia del vocablo "proyectar" con la técnica cinematográfica utilizada aquí, traída a colación desde la anécdota que encabeza este estudio), el autor escoge la mirada, la (re)creación de los hechos, donde el lente ocular, cual lente de 
cámara, recrea la imagen, por lo que invoca en latín que el tiempo transcurra lentamente, sino en cámara lenta: “<<O lente, lente currite noctis equi $>>$ ( 44$)$, concluye ${ }^{85}$.

Otro ejemplo que traemos es una especie de sobreimposición y desintegración de imágenes (copy and paste de la edición fílmica), que ofrecen tres tiempos de la casa. Para describir el hotel Trotcha al que se van a vivir los amantes, CI refiere tres tiempos, tres descripciones o regresos al mismo topos desde distintas épocas del topos.

Comprobémoslo como si fueran tres tomas de distintas épocas. La primera vez que aborda el edifico el hotel había sido un antiguo teatro: "A principios de siglo, el ala izquierda del Trincha había sido un teatro [...] pero ahora era la entrada al hotel que quedaba al fondo de jardines diversos" (191). Pero a finales del siglo XIX había sido "un balneario de moda, con cabañas que rodeaban una fuente que era un surtidor de aguas medicinales [...] en el siglo pasado" (192).

En el presente narrativo, verano de 1957, es el hotel Trotcha el "edificio de madera pintado de blanco" (191) al que se van a vivir los amantes fugitivos, que conserva el "frontis de mármol entre arcano y elegante" (191), y los jardines interiores. CI escoge el ángulo de mira fílmico, porque como en el cine, repite la referencia desde enfoques distintos, describiéndolo en sus mínimos detalles: "las puertas eran estrechas y débiles y las ventanas tenía venecianas" (191). Pero nótese cómo se percibe la voluntad de recrear este espacio en función de lo que tal vez es pura ficción, o tal vez es recuerdo — película de la memoria: "Siempre me gustó el Trotcha. Siempre quise vivir en ese hotel que era

\footnotetext{
${ }^{85}$ La frase, que proviene de la obra de Ovidio "Amore", y se traduce del latín como "Oh, corran despacio, despacio, caballos de la noche".
} 
mitad vergel, mitad laberinto, y ahora lo hacía por persona interpuesta pero en condiciones que hacían de mí y de ella el último refugio de dos desesperados" (191-92).

La ciudad cartografiada desde el exilio londinense, sobrepone los tiempos del topos; empecinado CI en reconstruir la capital cubana que ha sido vencida por la historia. Agonía del exiliado que busca restituir espacio y tiempo, como si saldara una deuda con el pasado. Rastrear la memoria y componer una topografía mítica, es lo que hacen $\mathrm{G}$ y su creador tácito.

\section{Drama-ontológico}

En LNI encontramos la ciudad antológica, intacta y milimétrica, topográfica, en la memoria; de ahí que la ciudad recreada por el autor se nos antoja como topos ideal para explicar la fenomenología del espacio de Bachelard: "La Habana está situada a la entrada del golfote México y recorrida de sur y a norte por la corriente del Golfo, entre los paralelos $19^{\circ} 49^{\circ}$ y $23^{\circ} 15^{\prime} \mathrm{N}$ y los meridianos $74^{\circ} 8$ y $84^{\circ} 57 \mathrm{O}$. El Vedado es un barrio" (LNI 172), refiere como si desde un artilugio fílmico sobrevolara la ciudad.

Esta es "La Habana que hace a los hombres y los gasta" (172), imbuida en una resaca social y que en breve se adentraría en una revolución. Imaginémosla: deambulaban los turistas americanos ebrios, la ciudad gozadora, bolerística, trasnochada — aquella que 1961 todavía pulsaba subrepticia, yéndose en la noche, captada por el lente aleatorio de Sabá Cabrera Infante en P.M. En poco tiempo daría paso a un orden social que cortaría de tajo la cotidianeidad y restringiría sus hábitos decadentes. Esta es La Habana de los 50 tardíos, vernácula-moderna, collage de barrios, tiempo-collage: el neobarroco, lo colonial, lo neoclásico, dando paso edificios modernos. La ciudad que — vivida, 
estudiada y recuperada con interés especial y espacial ${ }^{86}$ - , le permite a CI proyectarse en un espacio sin límites del recuerdo, que lo alivia de la quimera del exilio, de los avatares de una crisis nerviosa y del paso del tiempo:

En La Habana siempre se volvía a empezar. La Habana pareceaparece — indestructible en el recuerdo: eso la hace inmortal. Porque las ciudades, como los hombres, perecen. Un dicho en Cuba circa 1955 decía: "Olvida el tango y canta bolero". Queriendo decir deja a un lado el dramatismo y cuenta lo sentimental. Nada podía ser más exacto entonces -y ahora. (LNI 131)

Al escritor la evocación de la ciudad recordada lo aboca en la ciudad imaginada. El ser se extiende sin límites en la imaginación. El espacio íntimo del recuerdo es ahora el espacio exterior del geómetra. Pero tratemos de zafarnos de la metáfora fácil en la que el escritor vive del recuerdo, y hallemos aristas de la proyección ontológica.

Preguntémonos con el fenomenólogo: “¿De qué exceso de un interior ramificado se escurre la sustancia del ser? ¿Es que el exterior llama? ¿No es el exterior una intimidad antigua perdida en la sombra de la memoria?" (Bachelard, PDE 269). Tratemos de responder estas preguntas transfiriéndolas a la ciudad cabrerainfanteana.

El ser G se escurre en la ciudad. La ciudad es el cosmos, la morada del desterrado. Es el refugio asequible, la que se preserva contra toda contingencia. La ciudad se analiza racionalmente para preservársele poéticamente. En términos bachelardeanos, en la geometría soñadora es la ciudad del pasado ${ }^{87}$. La memoria de G está labrada en la

\footnotetext{
${ }^{86}$ Recordemos que CI fue sometido a tratamientos psiquiátricos que pudieron haberle afectado la memoria.

${ }^{87}$ Véase PDE, de Gaston Bachelard, página 80.
} 
memoria de la ciudad, circunscrita a sus parámetros, los que la habitaron, las casas, los cines, la vida nocturna, las atmósferas, etc.

Hemos visto que la ciudad adquiere las proporciones y la distribución del cuerpo humano, hasta el punto que la amante se hace ciudad también, se ciudadifica. De este modo, el reverie alienta esta construcción de la ciudad que se sale del tiempo lineal — comprimiéndolo — en una continuidad del ser ahí. Dice Bachelard: "Juzgamos el pasado. Nos sumerge una especie de remordimiento de no haber vivido con bastante profundidad” (PDE 88). G juzga el pasado y lo modifica, lo suple: Rescribirla, es el allanamiento del mapa de la ciudad recordada.

En LNI la memoria inconstante tiene un contexto: La Habana. Cuando Bachelard, para un estudio del ser, sugiere seguir los "circuitos ontológicos de las diversas experiencias del ser", y afirma que al "ser en espiral [...] toda expresión lo desfija" (PDE 252), nos enfrenta con dos paradojas: 1. En LNI el ser se fija en la ciudad; 2. Si para Bachelard resulta ridículo pedir dimensiones geométricas al poeta ${ }^{88}$, el novelista aquí tiene como condición necesaria referirlas, en pos de una poética de la ciudad. La experiencia de la ciudad se recrea en una memoria constructivista; la ciudad donde se proyecta el ser no está en la vida sino en la memoria imaginada, y escindida del contexto sociopolítico.

CI, todo lo vulnerablemente posible, inaugura su Habana como cine, una vez más en la literatura. No lo demos por axioma: Si para Bachelard "la imaginación es anterior a la memoria” (PDE 155), aquí el ardid es referirla como memoria vivida—lo que en algún

\footnotetext{
${ }^{88}$ Analizando unos versos de Pierre-Jean Jouve, el fenomenólogo defiende la imagen poética donde el "ser secreto" en este caso, se retrae: "Sería ridículo pedir al soñador sus dimensiones" (PDE 266-67).
} 
momento Bachelard propone como "recuerdos compuestos" (PDE 268).

Paradójicamente, sin dimensiones geográficas, la ciudad cabrerainfanteana — cabe especular- se debilitaría, se disolvería la poética del flâneur, el paradigma cinta-fílmicade-la-memoria, la ciudad-como-cine, la penetración del espacio isomorfo del cuerpociudad, y ciudadificación-de-Estela.

La datación geográfica colma la imagen de la ciudad — que es la medida del ser proyectado en ella - en una estética del detalle. La perspectiva del escritor tiene la gravidez del espacio real e imaginado. El exceso de concentración de datos lo fija ahí, heideggereanamente “a la mano", ensimismado. El soñador custodia la ciudad. O viceversa: El detallismo topográfico funge como la dinámica retórica que custodia al ser, lo recupera allí, al margen de la pérdida y del lastre del pasado.

Para explicar la fenomenología de la imaginación poética, Bachelard utiliza una metáfora que resume cómo el escritor, elaborando a solas una trama, se avoca en los detalles descriptivos: "El escritor quiere describir, porque conoce por anticipado, en kilómetros, el tamaño de su soledad. Entonces se sueña sobre el mapa, se sueña en geógrafo" (PDE 242). Concordantemente, la ciudad de CI es una exteriorización de la intimidad, que trae un drama de imágenes ${ }^{89}$, hallando expresión en la exteriorización poética de lo interiorizado. Dramático porque se resiste a la pérdida: “—Porque soy contrario al olvido" (LNI 36). El espacio interior se duplica en la ciudad, proyectado allí, el espacio del ser se inscribe en el espacio citadino, recompensándose de la pérdida.

\footnotetext{
${ }^{89}$ Tomamos prestado el modo en que Bachelard entiende la imagen descriptiva como trasmisora de sentimientos. Cuando Bachelard analiza la interiorización del desierto en el libro de Philippe Diolé, sostiene que estas imágenes no corresponden a la conciencia de una vacío íntimo, sino al deseo del escritor de transmitir un "drama fundamental de imágenes del agua y de la sequía" (PDE 243). Nosotros apuntamos al drama de la pérdida.
} 
Como hiciera $\mathrm{G}$ con el cuerpo de Estelita, al autor conquista el cuerpo de la ciudad, la intimidad del cuerpo-ciudad/Estela-La Habana, se zambulle en ella. Dos posesiones en

una, dos abstracciones al alcance de la escritura de la memoria.

Por otro lado, es plausible que el flâneur no le hubiera prestado tanta atención a la topografía mientras la vivía — La Habana estaba en plena efervescencia urbanística ${ }^{90}$ (a la par que subterráneamente cocinando una revolución), siendo una construcción literaria posterior, lo que queda confesado en la cita siguiente que ya hemos ofrecido: "La Habana no existía entonces" (13). El detallismo topográfico va en pos de una recuperación sobrecompensada de la experiencia. Para el autor, su otrora entorno físico se moldea, en una espacie de isomorfismo hembra. Porque la ciudad, como la "concha-casa" que ocupaba a Bachelard, va a extenderse en significantes, porque pertenece al "bazar de

\footnotetext{
${ }^{90}$ Sólo en el Vedado, y teniendo en cuenta únicamente grandes edificios y estructuras comunales, hagamos un breve repaso de la efervescencia urbanística de los años 50 y principios de los 60 dentro del estilo modernista: 1952. La Embajada de los Estados Unidos (actualmente aún cobija la Sección de Intereses de Estados Unidos en Cuba), con diseño arquitectónico modernista, por los Harrison y Abramovitz, Mira y Rosich. Vemos que en 1953 se erige el Retiro Odontológico, de los arquitectos Beale y Quintana, Rubio y Pérez Beato. 1953. Tribunal de Cuentas, ganado el Premio Medalla de Oro del Colegio de Arquitectos. En 1962 fue ampliado hacia uno de los terrenos laterales, respetando al estructura original. El elemento ideológico que adorna es el mural con la figura del Che Guevara. El edificio está ubicado en uno de los laterales de La Plaza Cívica, lo que constituye un eslabón en la arquitectura del miedo que acuña Nan Ellin. Véase Architecture of Fear (1995) en nuestra bibliografía. 1954: Ministerio de Comunicaciones. 1956: Se termina el Edifico Focsa, La Biblioteca Nacional, se concluye en 1957. 1958: Teatro Nacional, con capacidad para 2500 personas en la sala principal Avellaneda, y para 800 personas en la sala Covarrubias, además de un Café Cantante para 250 personas. Inaugurado en 1960, cerró poco después (1960 cerró). El Hotel Havana Hilton se construye en 1958 (nótese que se utilizaron materiales y técnicas nuevas para su construcción, como son el uso de encofrados de plywood y el cartón parafinado -ambos se usaban por primera vez en Cuba), cobija numerosas obras de artistas de la plástica cubana de los años 50, entre ellas un mural exterior en mosaicos bizantinos de Amelia Peláez -el mayor de su tipo en el mundo-, y uno interior de René Portocarrero. Este hotel fue nacionalizado en 1960 y a partir de esa fecha se llamó Habana Libre. Este mismo año se construye el Parque deportivo José Martí, en Malecón y G. También 1960 se termina la Plaza Cívica y monumento a José Martí (también modernista), plaza que construyó Batista y sin embargo se convirtió en símbolo del castrismo. 1960: El Ayuntamiento de La Habana. 1960: Renta de la Lotería. Valga el listando anterior para apuntar que el desarrollo urbanístico de La Habana en estos años, la magnificencia de estos edificios, apuntaba a un futuro de esplendor, interrumpido a partir del corte social profundo que significó la instauración de gobierno revolucionario en 1959salvando esporádicos proyectos que se concluyen en los 60 tardíos. Para tener una idea de la efervescencia urbanística que hemos aludido véanse The Havana Guide (1999), o la La Habana. Guía de arquitectura (1998), en nuestra bibliografía.
} 
antiguallas de la imaginación humana" (PDE 156). El ser, artísticamente fabricado, se proyecta en ella, alimentándose de los lugares comunes de la cultura, habanizándose.

Fenomenológicamente, la proyección del ser en el espacio es una cualidad emergente del ser. Queda claro que la ciudad es la "concha-casa" ontológica (volveremos sobre este concepto enseguida). Fuera de esa realidad literaria re-creada, el ser desterrado (CI desde su refugio en Londres se siente deshabitado de sí), retorna al topos urbano por vía de la escritura para hallarse en su reflejo. En la ciudad donde se proyecta G, se abre el espacio ontológico. Visto así, igual que el molusco "emana” su casa, el ser en falta emana su ciudad, su morada, extrayéndola del recuerdo. Aquí la ciudad es el refugio del que recuerda.

Para Bachelard el reverie (ensueño o ensoñación, pero entendámoslo como relato que se desprende de la ensoñación literaria, en el caso del escritor), es el equivalente fenomenológico de "la casa de la ostra" (PDE 153), ya que por medio del ensueño el ser fabrica su casa a cuestas, en la memoria y la imaginación. Por ello, las imágenes que se ofrecen de la ciudad en LNI no deben necesariamente ser confrontadas con las de la realidad (ya de por sí difícil de constatarse) — tentación en la que hemos caído (reconstruyendo la Trama-fílmica). El cuerpo/ciudad — ciudad fílmica de la memoriase somete a resucitación por medio de la imaginación y la voluntad, reverie literario donde el ser crea su propia concha/ciudad, nicho del exiliado.

Nos equivocaríamos si viéramos aquí solamente mañas de estilo y topografía retórica. En el exceso mismo de esa retórica, alerta Bachelard, se manifiesta en su 
profundidad la intencionalidad del ser: "Para tales ensueños, la forma es la habitación de la vida" (PDE 149) —y el ser busca perpetrarse y perpetuarse ${ }^{91}$.

Así refiere CI, con arrojo metaficticio, la intencionalidad de la memoria, también, la memoria como la cinta fílmica, alegoría de la vida como un filme:

Pero lo que recuerdo ahora es lo que quiero recordar: a Peruchín tocando "Total" en la oscuridad y en el frío de ese night-club que era toda la noche en pleno día. Ella, por supuesto, no recordó nada: no le interesaba. Pero quiero recordarla en el frío de Canadá y en la tumba oscura. Piensen, por favor, cuánto se parece recordar a grabar, en inglés. Recordarla a ella es grabarla en el recuerdo. Yo la recuerdo toda. (LNI 107)

No podía ser de otro modo: la imagen queda grabada en la cinta-fílmica-de-la-memoria.

\section{Ciudad-lenguaje}

La escritura aquí es una submodalidad de la memoria, y la memoria es fílmica (y la novela es una modalidad del espacio): "Escribir, lo que hago ahora, no es más que una de las formas que adopta la memoria" (18), corrobora G.

El lenguaje en LNI, es correspondiente con la ciudad, presentándose como collage, casi dadaísta — con bastante más sentido del sinsentido existencial一, dice y desdice, serpentea lúdico, sortea el significado, incansables anfibologías, aliteraciones, paranomasias, calambures, aliteraciones, cromatismos, etc., entradas y salidas del relato en un guiño al lector, coloquialmente, ya sea para justificarse, en caso de que éste pueda reprocharle las transgresiones lingüísticas o arbitrariedades a los que se somete el

\footnotetext{
${ }^{91}$ Dice CI: "Toda literatura está hecha de lenguaje. El lenguaje estaba antes que siquiera se sospechara la literatura y seguirá estando después que ésta sea olvidada. ¿Cómo no preocuparse por una forma de eternidad?" (Pereda, Cabrera 103).
} 
lenguaje, el sentido y la memoria. Sus circunlocuciones homenajes — collage de influencias ${ }^{92}$, mnemotecnia, apropiaciones y aliteraciones parodias, los préstamos del inglés, todo un juego que a veces es un callejón sin salida, o crea un suspenso como en el cine. Busca expresar el placer in-sano en la trasgresión, en el degustar sensual de ciertas contradicciones y coincidencias del lenguaje y la literatura. Eróticamente la expresión se expande y se contrae — dentro de otros paralelismos eróticos. Lo que denota una fijación lúbrica, no sólo ante el objeto del deseo de G, que es Estela, menor de edad, también con el lenguaje. Esparcimiento que admite en apartes con el lector, buscando su complicidad: "(Me gustan las rimas impensadas)" (11). O para expresar que se le hace inevitable caer en el juego verbal, contaminando el valor semántico: “(Es que no puedo, no puedo evitarlo)" (99).

El disfrute en la falta, la invención de vocablos a apropósito y por puro juego, la prevaricación de la ficción, son paralelos a la trasgresión sexual, que en la novela está dada en la conquista de la amante púber, la infracción con la ninfa: "Perder la virginidad puede ser un accidente" (145), explica. "Estelita se convirtió en estela" (278) —que al perder el diminutivo -ita anuncia que pasó de niña a mujer, pero también implica la fugacidad de su presencia (el autor omite la mayúscula). La frase continúa así: "Fácil juego de palabra pero difícil de hacer, de construir una oración que lo contenga y al mismo tiempo la deje fuera" (278) — presume.

Para esta lectura polifónica, démonos gusto — a gusto del autor: “Amar quiere decir, según el bolero, encontrar una diosa" (66), y de acuerdo al diccionario la ninfa es

\footnotetext{
92 Puede consultarse la entrevista incluida en la primera monografía de CI, de Rosa M. Pereda, desde la página 100 a la 141, donde CI explica sus influencias, sus "monstruos literarios".
} 
una divinidad menor, una nereida, dríada, náyade, sílfide, sirena, deidad de los bosques, las selvas y las aguas; llámesele también a la mujer de costumbres libres. En la zoología es el insecto en estado de desarrollo entre la larva y la forma adulta, o púber, con desarrollo incompleto de las alas. Es lo que se rompe para dar paso a la mariposa: "Antes de llegar s a su esplendor, la mariposa debe permanecer inmóvil por un tiempo hasta romper la ninfa" (LNI 94) —así pasa Estelita Morris de niña a mujer, cuando el narrador/autor le causa una ruptura a la ninfa, desvirgándola. Una de las acepciones del plural de ninfa es precisamente labios pequeños de la vulva. También hallamos una relación con la acepción etimológica de ninfomanía, en cuanto a que las ninfas estaban al servicio de los dioses, muchas terminaban matrimoniadas con patriarcas. El lenguaje está minado por la vida misma, que puede leerse cual palíndromo existencial: “-La vida, rica, no es más que una trama de coincidencias" (130).

Otro coincidencia semántica puede hallarse: las ninfas estaban unidas a topos: mares, ríos, lagos y fuentes — masa de agua en el bosque. Como se ha visto, el topos de la ninfa cabrerainfanteana es la ciudad, la selva urbana de La Habana — pero de la que ella parece estar emocionalmente distanciada. Es que Estelita está emocionalmente desunida de todo. Como Estelita, las Nereidas son ninfas con malicia, caprichos y pasiones: Estelita le encarga al protagonista el asesinato de su madrastra: "Quiero que mates a mamá" (83). Como las mariposas, Estelita tendrá una corta vida: "Era una mariposa acabada de salir de su crisálida" (98).

El collage con el leguaje está dado en la sobreimposición semántica constante. ¿Qué se superpone en el lenguaje? La utilización de cualquier cantidad de figuras poéticas y retóricas, juegos sintácticos. Lo onomatopéyico — ejemplos de ello son, la 
fijación con la $\mathrm{O}$ que recorre gran parte de la obra de CI, alcanzando LNI, la sonoridad del calambur, la aliteración, la metonimia, la sinécdoque, etc. También, lo aleatorio de traer palabras por otras en virtud de su sonoridad, lo asociativo y disociativo confluyendo una ciudad con el lenguaje. En la sobreimposición del collage lingüístico hay sobreimposición de tiempos. En ese sentido, los diálogos resultan antojadizos, azarosos, fluyendo espontáneamente en su riqueza semántica — como ciudad que se va construyendo gradualmente debido a las demandas de consumo: “- Cómo tú sabes cosas, tú" (112), espeta ella en su mejor argot habanero, sin entender apenas los malabarismos verbales de su amante.

El juego aleatorio del lenguaje trae piezas sueltas de su historia con las que transcribe su collage de memorias vividas en la ciudad, ciudad/Estela. La tierna protagonista, Estela, Stella, Estrellita, es la imagen urbana que se ha penetrado ${ }^{93}$.

¿Qué hace $\mathrm{G}$ con el lenguaje? Collage de la memoria, proyecciones sonoras de ésta, la memoria del lenguaje y el lenguaje de la memoria. Por ejemplo, nótese que en la cita siguiente G trae una referencia a un popular bolero cubano circa 1955: "Olvida el tango y canta bolero", para inmediatamente después, cuando ofrece una explicación de la frase, echar mano de otro célebre bolero del compositor Urbano Gómez Montiel “'Canta lo sentimental' [...] queriendo decir deja a un lado el dramatismo y cuenta lo sentimental" (131). El segundo bolero parafraseado aquí data de 1962 y fue popularizado por Meme Solís, aunque también fuera grabado por el grupo Los Zafiros más tarde —lo que presenta un anacronismo. Prueba que el elemento aleatorio del lenguaje parte del

\footnotetext{
${ }^{93}$ Aquí planteamos una analogía entre la protagonista como imagen poética, siendo ella expansiva al espacio-ciudad, y la imagen que en cuyos esfuerzos repetitivos se ha penetrado, según Bachelard (PDE 268).
} 
arsenal de experiencias del autor, que abarca el pasado que revive, sujeto a la experiencia posterior que lo contamina. No es importante el orden cronológico. Al contrario, lo importante es la trasgresión de ésa cronología — tal cual se aglomeran en la ciudad edificios de distintas épocas.

La infracción del lenguaje discurre paralela a otra falta mayor que ya hemos abordado al principio de este estudio: el tema espinoso de estupro. Se acumulan los significados, se dilata la semántica; el impacto del cine en el lenguaje, es equidistante a los anuncios lumínicos de la Coca-Cola o de Colgate en la fachada habanera. Esta escritura es collage, como la ciudad misma — donde edificios y estilos se superponen, donde el significado está en el interior del espacio, cual etimología por revelarse, o se exhibe como exceso.

Es poco probable que la perfección de estilo, la mordacidad lúdica, el goce fonético —elementos reflexivos-y la experimentación aleatoria constante con el lenguaje, fueran dominios del joven $\mathrm{G}$, siendo más bien atributos posteriores, cultivados en el tiempo (del escritor). El G de finales de los años 50, es proyectado en el pasado con destrezas del G desde el presente de la escritura. ¿Cuál es el presente de la escritura? El presente es acaso "un nanosegundo [sic] puede durar una eternidad y ser la medida del universo" (82). Si CI empezó a escribir la novela en apuntes que datan de $1962^{94}$, preguntémonos cómo es un nostálgico temprano, y cómo las intervenciones desde el presente se muestran distendidas en el tiempo. La respuesta está en la cualidad elástica de la memoria bergsoneana, la durée expansiva: "Nada de mañana y mañana para mí sino

\footnotetext{
${ }^{94}$ Referido por Miriam Gómez en la anécdota que encabeza este capítulo.
} 
hoy, hoy, esa palabra que puede ser un hoyo pero que era, en este momento que dura más de un momento, una suerte de eternidad" (41).

También es el brote, la sobrecompensación que provoca el "vacío de sinlugaridad" todeseano que ya hemos abordado. De hecho, la experiencia de la lectura de cualquier obra de CI se completa encontrando conexiones culturales (cultas y populares), literarias, musicales, cinematográficas, regionalismos habaneros que hacen las delicias al lector — más fáciles de comprender para un cubano que para un británico. La biografía accidentada del autor, marcando pauta aquella mudez infantil que Santí, desde un análisis psicoanalítico, califica como afasia (provocada por el traumático arresto y la encarcelación de los padres cuando CI tenía siete años), actuando en la configuración de un "sentido peculiar de la escritura y la literatura" (Infantería 16), y luego la censura (primero batistiana y castrista después), es sobrecompensada en la profusión verbal. De cierto modo rompiendo, en palabras de Rosa M. Pereda, la contradicción milenaria entre escritura y oralidad, resuelta en los juegos de palabras cabrerainfanteanos, "herencia directa del pun británico, de las palabras-maletín de Lewis Carroll y los calembour de Joyce" (Mi música 15-16). Captando la voz en vivo, sometiendo la ortografía a la oralidad del habla cubano-habanera. LNI podrá leerse sin la ayuda de consultas al diccionario y enciclopedia, disfrutándose, sin duda. Pero se leerá mejor resolviendo las cápsulas códices que el autor dejó cifradas en cubano-habanero. Sólo un lector activo saboreará de ellas, y de etimologías, perífrasis y construcciones sintácticas de significado expansivo.

En LNI encontramos este tipo de consultas enciclopédicas, digresiones de la trama que fungen como simetrías poéticas. Analicemos el siguiente extracto, último 
párrafo de una referencia científica sobre las mariposas (de poco menos de dos cuartillas), insertada en la trama en medio de una cita amorosa con Estela:

Las mariposas se alimentan de néctar que recogen, como dice el bolero, "libando de flor en flor". Los aparentes adornos de las alas atraen o repelen a sus enemigos y son un efectivo camuflaje natural. Algunas especies de apariencia encantadora se alimentan de carroña. La más numerosa especie pertenece a la familia de las ninfas. Todas las mariposas suelen vivir vidas cortas. Estela era pequeña [...] De hecho era más pequeña que mona. No era una gema pero parecía genuina, con más carácter que carates. Ya sé, ya sé que se dice quilates, que rima con dislate. Pero ¿quién quiere corrección en una lengua cuando puede hablar dos? Bípedo, bífido. (LNI 95-96)

Describe entonces detalles nimios de la apariencia de Estela: el vello rubio bajo el sol, los "ganchitos en el pelo", la desnudez púber evidenciándose bajo el vestido blanco. A la par, ofrece detalles del encuentro y del topos: la esquina de la 12 Avenida y la calle 23, el edificio chato en el fondo. Dice: "Era una mariposa recién salida de su crisálida [...] Comprendí que se había pintado parapintado [sic] para la guerra. Ella quería batalla pero a mí me pareció una mascaramuza [sic]. (Es que no puedo, no puedo evitarlo.)” (98).

Nótese que el autor/protagonista va del dato que ofrece la Enciclopedia británica sobre las mariposas, a la catadura del objeto del deseo, que es Estela, donde sobresalen las antítesis: la atracción por lo bello/desagradable, ingenuidad/malicia, pubertad/madurez, y contrastes como: "infección amable" (14), "embargado por su más 
rancio perfume" (99). Es que las flores como ella, "eran todas luminosas y perfumadas y perfectamente ponzoñosas" (128).

Para el que recuerda lo importante es fijar el momento, cual mariposa pinzada por el coleccionista, atrapar el momento que son muchos momentos, desglosarlo en la memoria, recomponer la emoción fílmica del recuerdo. El vano ejercicio de captar el instante eterno, o eternizar el instante; ¿no esto lo que trata de hacer el medio cinematográfico? Estela queda "detenida un instante en el espacio para detenerse para siempre en el tiempo" (29). Lo que fue "un momento en el momento" (36), se extiende en virtud de la memoria: "Estela ha durado más, dura todavía (233).

La durée bergsoneana es la duración espacio-temporal de la vida:

Cómo llamar a un momento que dura menos de un momento pero va a cambiar una vida. Factum es fatuo. Destino es cuando una fuerza irresistible tropieza con el objeto inmóvil que tú eres. Destino es también desatino. Ahora sé que el momento en que la vi por primera vez fue un momento equivocado. (230)

En resumen, el ser se vierte en la compresión de la experiencia narrada e inventada, reverie de un collage de la memoria que se resuelve en el lenguaje como ciudad: sobreimposición de edificios y datos topográficos, épocas, jerga habanera y trasgresión del lenguaje para un mismo topos, que es La Habana de este momento único — presentado en mala fe sartreana — como estela fugaz: "La anfibología me permite decir un momento de amor, pero me obliga a decir que duró más de un momento. Ah, amor" (233). El espacio-temporal, definido como lugar en el caso de LNI, bergsoneanamente se elastiza, expresándose por medio de la memoria fílmica. Tratándose de memoria como 
vehiculo de proyección ontológica, trajimos el concepto de la "nostalgia reflexiva" de Svetlana Boym, porque G hace del espacio público de la ciudad un "lugar" íntimo, una morada literaria. La topografía personal sobre el mapa de la ciudad, la trama urbana en el filme de la memoria: Absorción de lugar dentro del drama del exilio. 


\section{CAPÍTULO III}

\section{TODOS SE VAN DE WENDY GUERRA: ANULACIÓN DEL SER COMO MODALIDAD DEL SER}

Nieve Guerra, la protagonista de Todos se van (1er Premio de Novela Bruguera 2006) habita un topos de tipo sentimental; como Marcel Proust, ella está buscando la memoria de sí, sin otro fin que la supervivencia. La protagonista, alter ego de la autora, recurre a una dignidad trágica, si se quiere, una reivindicación de su experiencia: la experiencia del abandono, y la experiencia de haberse quedado cuando todos se hubieran ido. En ese sentido la novela Wendy Guerra contiene a La ninfa inconstante (2008) de Guillermo Cabrera Infante.

CI (y G) es uno de los que se fueron de la realidad lacerada de Nieve/WG. Los protagonista cabrerainfanteanos están contenidos en el pasado de la ciudad que ahora habita Nieve — cual ninfa de la distopia urbana. La sensación de abandono recorre la novela de WG, ofreciendo el paisaje desolador donde Nieve es la anti-heroína en la épica del abandono. Nieve/WG es la heredera de la isla abandonada "a la deriva" (TSV 285). Presionando la metáfora, la autora de TSV y la protagonista de LNI se relacionan en el nombre: la Wendy del cuento infantil, se deja guiar junto a sus hermanos por Campanilla —especie de ninfa meñique ${ }^{95}$, conciencia/consejera de Peter Pan—a una aventura sin regreso al "País de Nunca Jamás", que es la niñez eternamente prorrogada. Esta Wendy es la narradora de las fantasías infantiles, amenazadas por las reglas de los adultos. La Wendy autora de TSV narra el bildungsroman de Nieve —igualmente amenazada por el

\footnotetext{
${ }^{95}$ Una de las acepciones de ninfa es, precisamente, “consejero o director de una persona, a quien impulsa de manera sigilosa o poco ostensible" (http://buscon.rae.es).
} 
mundo de los mayores. Salvando distancias, Estelita y Nieve son dos adolescentes extraviadas en el "País de nunca jamás" — que también puede ser esa Cuba varada en el tiempo y la ruina, en la parálisis sociopolítica. En el futuro truncado de la Estelita de CI, se vislumbra la Nieve aterida de WG. La fuga del ser y del tiempo son material de ambas novelas.

Todos se van está escrita a la manera de un diario, divida en dos, "Diario de infancia" y Diario de adolescencia" (por lo que cuando hagamos referencia la primera parte nos referiremos a la niña, $\mathrm{y}$ en la segunda parte a la adolescente que despunta en joven). Abarca desde junio de 1979 a abril de 1990. Es pues el relato de la infancia y adolescencia de Nieve Guerra, protagonista, igual que la autora, nacida en Cienfuegos en 1970. La novela relata el bildungsroman de la hija de una locutora radial de provincia y un padre teatrista, alcohólico y abusivo. Nieve se convierte en la manzana de la discordia tras el divorcio de ambos. Pero mientras la madre rehace su vida casándose con un extranjero (el sueco Fausto), el padre despechado las lleva a juicio, obteniendo la custodia de la niña.

A través de las páginas del Diario de Nieve se filtra la realidad social de una Cuba militarizada y socialmente tensa —con su válvula de escape en el éxodo del Mariel ${ }^{96}$, y la Cuba aún más depauperada e inmovilista que despunta en el Periodo especial ${ }^{97}$. Es la

\footnotetext{
${ }^{96}$ El éxodo del Mariel, que durara del 15 de abril al 31 de octubre de 1980, marcó un punto de giro en la historia de la Cuba revolucionaria, cuando 125000 cubanos lograron salir de la isla rumbo a Estados Unidos, a través del Puerto del Mariel, en la costa noroeste. Los hechos se produjeron a partir de que el 5 de abril de 1980, 10 mil cubanos se asilaran en la embajada del Perú, en La Habana. Como solución al caos el gobierno cubano y el gobierno estadounidense abrieron las costas, y por medio de salvoconductos otorgados por el gobierno de Cuba, miles pudieron abandonar la isla.

${ }^{97}$ El llamado "Periodo especial" se dio en la primera mitad de los años 90 en Cuba. Fue este un periodo de acentuada estrechez económica que atravesó la isla después de perder el apoyo económico de la URSS, tras la renovadora Perestroika de los años 80 y la subsiguiente la caída del muro de Berlín 1989, con el
} 
Cuba post socialista, si se quiere — post caída del muro de Berlín, sin haber renunciado al socialismo cerrada en sí misma, de la que Nieve y su madre no lograrán escapar.

Así mismo buscamos problematizar la manera de cómo el ser, que no sabe verse, reconocerse en el engranaje social: “¿Quién seré yo?”(197), se pregunta Nieve, y aún crea un espacio para sobrevivir en una sociedad totalitaria, autoritaria y patriarcal. La mauvaise foi sartreana se explica como una incapacidad del ser de verse a sí mismo, de comprender su ser ${ }^{98}$. La mala fe sartreana $-\mathrm{o}$ falsa conciencia — es una manera del ser de estar, si se quiere, en el closet de la realidad, es una incapacidad, es presentarse el mundo a sí mismo para justificarlo — en cuanto a que toda incapacidad es la capacidad como una negación de. Comprender estas contradicciones del ser reflexivo — su Diario/novela es vehículo expresivo-reflexivo - es requisito fundamental al adentrarnos en el texto de WG/Nieve.

De modo que en el caso de la novela que nos ocupa, dispondremos que la negación del ser Nieve es una modalidad del ser Nieve. Ser Nieve es una composición: la Nieve que emana del Diario, es el rasgo más crudo del ser, es la que se resiste al poder y es la que se somete (ser Nieve es también esa contradicción). Puede argüirse que ya Nieve es una negación de WG, en cuanto a que quien escribe el Diario es un personaje ficticio (¿o será Nieve simplemente un seudónimo de la autora?) ${ }^{99}$.

\footnotetext{
desmoronamiento del bloque socialista de Europa del Este. La pérdida de su principal aliado y protector, vino acompañada de una incertidumbre social sobre cuál sería el camino que tomaría el proyecto socialista cubano.

${ }^{98}$ La mala fe que ya hemos referido. Véase Essays in Existencialism de Jean-Paul Sartre, páginas 167-69.

${ }^{99}$ Wendy Guerra firma como Nieve algunos de sus poemas publicados en nuestro blog personal. Búsquese en la sección de temas por Copos de Nieve, <www.tumiamiblog.com> .
} 


\section{El espacio ontológico constatado en el cuerpo}

El contexto histórico de TSV, es relevante para comprender cómo el aislamiento y la inmovilidad sociopolíticos en que se sumerge la isla después del derrumbe del bloque socialista, afectan psicológicamente a la protagonista: “A la deriva viajo poco a poco hasta la inmovilidad total" (285) — dice Nieve como si se sintiera identificada con la isla suspendida en el Caribe. Viene al caso Edmund Husserl cuando explica que gracias el cuerpo se está en medio de las cosas ${ }^{100}$. Pero lo importante aquí es que para Husserl la experiencia del espacio se consigue con el movimiento, en el "Lebenswelt", que es el "mundo-vivido"; Nieve le da la razón cuando constata la imposibilidad de desplazamiento, impedida de experimentar el mundo:

Estoy en La Habana, lo intento, trato de avanzar cada día un poco más. Pero una vez helado el mar Caribe, no hay posibilidad alguna de llegar a ningún sitio. De este lado sigo escribiendo mi Diario, invernando en mis ideas, sin poder desplazarme, para siempre condenada a la inmovilidad. (285)

Para la adolescente Nieve la experiencia del espacio es, husserleanamente, la medida de su cuerpo menudo, cuartado su desplazamiento. Nieve no escribe fantasías (o no las confiesa al Diario como tales), sino que relata lo que se supone sea la experiencia en el ahora, en la inmediatez de un cuerpo de 17 años, dibujando una analogía entre país y cuerpo femenino: "He sabido que una mujer y un país deben ser habitados, tocados, vividos, aunque el precio sea un abandono presente y sombrío” (280). La analogía cuerpo/país — que veremos reiterarse en la novela — plasma una poética del espacio

\footnotetext{
${ }^{100}$ E. Husserl: "Gracias a mi cuerpo estoy en el centro de las cosas” (Casey 217).
} 
ontológico a partir del cuerpo físico. Nieve constata su individualidad, coartada por demás — como veremos, y trata de reconocerse en la dificultad: “¿Quién soy, qué quiero, adónde voy? Estoy masticando este vidrio de sal que trae el aire en mi ciudad" (276).

Pero La Habana de Nieve dista mucho de ser la de G en LNI. La ciudad plasmada en LNI, en plena ebullición urbanística, vital y dinámica, referida al margen de las tenciones políticas, contrasta sobremanera con La Habana depauperada y socialmente inflexible de TSV. Además (a diferencia de la preponderancia que ésta tiene en LNI), La Habana en TSV aparece circunstancialmente en el "Diario de la adolescencia", quedándose fuera de la precaria intimidad de Nieve, cual metáfora orgánica, aplastándola como una losa desde el exterior.

No obstante, el espacio urbano emerge desde distintos medios: desde el desaliento, la abyección, la desidia existencial, los sentimientos de escapar, la miseria, el deterioro físico y social, la inmovilidad, la perspectiva marginal y la perspectiva privilegiada, las expresiones de miedo, la paranoia, el ser socialmente desencajado, la toma de conciencia de la protagonista, etc. La ciudad desatendida por un sistema que la desprecia, va desmoronándose en el tiempo, y Nieve, que vive con su madre en un solar ${ }^{101}$ paupérrimo en Centro Habana lo constata en su día a día: “Dios mío, sentí que La Habana se está derrumbando y recordé que mi casa está declarada inhabitable" (193). De los escombros de ciudad emerge espaciadamente la estética quimérica de la

\footnotetext{
${ }^{101}$ En el argot popular cubano, un "solar" es una antigua casona de familia rica en la capital, donde hoy en día viven varias familias hacinadas, independientemente instaladas pero con baños comunes, generalmente en condiciones de extrema pobreza y ciertas dosis de promiscuidad.
} 
sovietización ${ }^{102}$. Solamente hacia el final del Diario-novela la protagonista parece revindicar el espacio citadino, y para ese entonces la ciudad física ha quedado fuera del relato.

Se hace relevante retomar el ensayo de Elizabeth Grosz "Cuerpos-ciudades"103, que articula la relación entre cuerpo-ciudad, acuñándola con el término "ciudadificación": "Como un borde entre la población y el individuo, el cuerpo, su distribución, hábitos, alineamientos, placeres, normas e ideales son objetos ostensibles de las regulaciones gubernamentales, donde la ciudad es un instrumento clave" (246). Es que para Grosz "El Estado prefigura el cuerpo; el artificio es espejo de la naturaleza" (246) - lo que plantea una relación artificial, inorgánica, impuesta. En cierto momento sobre el que volveremos luego, Nieve, entrenándose en el Campamento Militar, granada en mano, parece darnos la razón: "Nosotros encerrados en esta cerca, aprendiendo a matar a alguien que aún no sabemos quién es" (154).

Se ha visto que para Grosz, el isomorfismo cuerpo-ciudad es biunívoco: "Contrapartidas congruentes, en las cuales las figuras, la organización, y las características de una son reflejadas en la otra" (246). Grosz señala que la

\footnotetext{
${ }^{102}$ Rafael Rojas, en El estante vacío (2009) coincide con Emma Álvarez-Tabío en cuanto a que la época del patronato soviético "no parece haber dejado rastros visibles en el espacio arquitectónico ni en la trama urbanística en la ciudad" (64-65), más que en la periferia capitalina y en aislados edificios simbólicos: "Surgen ciudades-dormitorios en el Este, como Alamar, ejecutadas desde la estética despiadada del gregarismo desarrollista, y parecen, también, enclaves simbólicos en la periferia, como el Parque Lenin y la Escuela Vocacional del mismo nombre, inaugurada por Leonid Ilich Brezhnev en 1975, edificios fríos y duros, como la embajada de la Unión Soviética, en pleno Miramar, que imita la arquitectura cósmica de Moscú y otras ciudades soviéticas, o el olvidado monumento a la Crisis de Octubre a la salida del túnel habanero" (65).

${ }^{103}$ Ya recurrimos al ensayo de Grosz en el Capitulo II de este estudio. "Bodies-Cities" está incluido en Sexuality \& Space (1992). La edición de Beatriz Colomina reúne a varios estudiosos de la arquitectura y la urbanización, desde un enfoque del espacio que ocupa la estructura arquitectónica y/o urbanística como representación, ya sea de lo político, del tejido social, o del ámbito doméstico.
} 
correspondencia entre cuerpo-ciudad se expande a cuerpo-político, en cuando a que se establece un paralelo por expansión entre el cuerpo y el orden social: "La correspondencia entre el cuerpo y el cuerpo-político es más o menos exacta y codificada: el rey (entiéndase la figura de poder) usualmente es representada como la cabeza del cuerpo-político, y el pueblo como el resto del cuerpo" (245). La estadía obligatoria de Nieve en el Campamento Militar, es quizás el ejemplo que mejor ilustra la analogía cuerpo-político que describe Grosz. Nieve se ve forzada a convertirse en cuerpo de combate:

No tengo hambre pero hay que ir. Esto es un régimen militar. Hay que obedecer órdenes. El deseo queda guardado en la casa, en una caja, bajo llave. Aquí uno cumple los deseos y caprichos de alguien, supuestamente superior a uno, que tiene ganas de medir fuerza con las mujeres o los seres sensibles que le rodean, todo en nombre de la patria y para matar a un enemigo que no existe. La ropa verde olivo nos confunde a las unas de las otras. (157)

También, grosceanamente comprendido, conjuntamente con la ciudad, el individuo identificado con el locus "cuerpo-ciudad", queda escindido. Veamos otro ejemplo de esta particularidad en voz de Nieve:

De pronto, el edificio de enfrente se derrumbó en un instante. Se desplomó en mi cara como si nada; se fue abajo así, de un tirón, dejándome en la calle como una pequeña lámina de cristal cuarteada. Tendida en el piso, yo podía ser otra partícula de polvo que voló en la vieja Habana como tantas. 
Mientras el símil anterior ilustra cómo Nieve se siente una "partícula" de la ciudad, el siguiente ejemplo, especie de autorretrato, ilustra cómo su ser se proyecta en ella: “¿Quién seré yo? Un poco de todo, un poco de nada, un rompecabezas de lo vivido. Soy Nieve en La Habana” (197). Valga anotar que la autora retomará la premisa de la nadería existencial luego, con la protagonista de su segunda novela (también a modo de diario), Nadia Guerra, formulándose la idéntica pregunta: “QQuién soy?” (Nunca fui, 145). Mientras Nadia es la nada, Nieve es una posibilidad improbable.

O sea, soy casi un oxímoron, porque en La Habana no nieva; mi lugar es el sinlugar. O en La Habana si nevara: mi lugar es contradictorio pero plausible, soy esa posibilidad de que (N)nieve en el trópico — parece decir Nieve.

Un cuerpo-ciudad femenino desatendido por un Estado-cabeza-política patriarcal que le desprecia. El hombre construyó la ciudad a su medida, de modo que el cuerpociudad femenino encaje en el modelo patriarcal. Pero el nuevo paradigma que se instalara a partir de 1959, aunque continúa al mando un poder patriarcal, es rotundamente narcisista. La cabeza-Estado, absorta en el poder — cual imagen de un espejo, solo tiene ojos para sí, prescindiendo de cuerpo-ciudad femenino.

\section{La imagen mariana de sí}

En prólogo la narradora ofrece una imagen beatífica se sí misma, aparentemente inofensiva: "No sé ni en qué momento permití que me quitaran todo y me dejaran sola, desnuda, con el Diario en una mano y un carmín en la otra, tratando de colorearme la boca de un rojo que parece demasiado subido para una edad indefinida" (10). Pero que también, de cierta manera describe lo que creemos que la autora se propone con el libro: la literatura como una ofensiva al poder patriarcal. Veamos: Dicha soledad denota 
orfandad de espacio (ontológico). Solo así Nieve se siente despojada de todo. No obstante la estampa, casi religiosa, trasciende el arquetipo por profana, y es en ese sentido una variante de la Lolita/Estela de CI, ofreciéndose desnuda, virginal y seductora.

La acentuación del carmín como símbolo de feminidad es a un tiempo atrevida y cándida, siendo el rojo carmín lo femenino, la pasión, la intensidad por vida, la precocidad adolescente, etc. En la otra mano sostiene la "transcripción privada", que es el Diario (sobre este término volveremos enseguida). En cada una de sus manos empuña un elemento que la exime de la participación en la dinámica del poder patriarcal; también son armas de su ser, desde "una edad indefinida", "trata" de utilizar para defenderse de éste.

Desnuda ante el poder, la joven esgrime la pureza y la voluptuosidad del desnudo femenino, más dos armas de permanencia in sito (en su ser), y de resistencia: el Diario y el carmín. El desnudo de la imagen ideal — referida como estampa mariana, contrasta con la incapacidad que tiene Nieve de desnudarse en su propia casa (la que comparte con su madre). No está de más constatar que el desnudo aquí trasciende lo literal; siempre es de doble filo: desnudarse también es sincerarse, no fingir, manifestarse tal cual y sin ambages. Como veremos más adelante, la narradora/protagonista será consecuente con esta imagen de sí, pero también traicionará el desnudo virtual que la imagen propone.

\section{A. Modalidad "transcripción privada" en el espacio sitiado}

El fenómeno de la Revolución cubana (1959-) es fondo temático en la creación del espacio imbricado en el texto de WG que, se ha visto, abarca a partir del año 1978 hasta 1990. Por ello es relevante el estudio de James C. Scott, Domination and The Art of Resistance (1990), el cual ofrece una perspectiva del individuo en relación con el poder, 
estableciendo dos transcripciones, una pública y otra oculta, privada (2). Desde el Diarionovela de WG, nos interesa analizar los códigos que transcriben el fenómeno de subordinación y resistencia al discurso del poder. Cabe preguntarse hasta qué punto es en la relación con el poder, donde se definen los espacios que WG recrea.

Scott define la "transcripción privada" como la transcripción escondida, oculta, y por esta razón es un "territorio" privilegiado por "no hegemónico, contrapuntal, disidente", donde se articula un "discurso subversivo" (25). Si nos permitimos una expansión semántica, la palabra "site" que utiliza Scott, y que se traduce como "territorio", tiene entre sus acepciones del inglés "yacimiento", que en español significa lugar donde se hallan fósiles. De cualquier manera Scott está hablando de un "lugar" donde el individuo se permite este fenómeno ${ }^{104}$.

Abordemos la compleja relación entre la "transcripción privada" y la “transcripción pública" que ilustra el siguiente pasaje del Diario, cuando una amiga de Nieve que se va de Cuba, está despidiéndose tácitamente de ella:

Cleo me ha regalado seis sombreros $[\ldots]$ Creo que esto puede ser una despedida. Quizás me doy cuenta por el propio ejercicio de decir adiós en el que he sido entrenada. Yo le regalé un poema dedicado a ella [...] Se lo dejé en un sobre cerrado para que lo lea en París. Nos besamos en silencio, sin decir una palabra sobre el asunto. Ella también le teme a los micrófonos $[\ldots]$ No confío en nadie. No espero por nadie. Así me educaron y así soy. (235)

\footnotetext{
${ }^{104}$ Scott, op. cit.
} 
Scott explica una dinámica insertada aquí, que se da entre la "transcripción pública" del que está en el poder, y la "transcripción pública" del subordinado alejado de las jerarquías de poder, como una relación entre el poderoso y débil, donde el débil debe manifestar públicamente y repetidamente su lealtad al poderoso. De este modo la "trascripción pública" es el soporte del poder, siendo el "retrato crudo de la elite poderosa", explica (17-18).

El Diario de Nieve se presenta como "transcripción privada" inestable, debido a que es un texto asediado: "Le temo al Diario" (261), confiesa; o lo que es más inquietante: "Le miento al Diario" (263). Veremos que la presión hegemónica del poder la coacciona, confinando la "transcripción privada" a una precariedad que la condiciona (sobre esta problematización de la "transcripción privada: volveremos enseguida). Asediada por el terror y por la imposibilidad, se mide en lo que escribe, llegando a traicionar la verdad de los hechos. Entonces, Nieve mantiene con el Diario una relación ambigua; lo que avanza dos temores: uno es que sea descubierto, y otro emana simplemente de escribirlo—que es una manera de hacerlo público. Para que se dé la "transcripción privada" se requiere un mínimo de intimidad, pero el ámbito privado de Nieve también está amenazado por un hogar inestable, donde tanto la niña como la adolescente Nieve, nunca se sentirá protegida.

\section{La casa inestable de Nieve}

La problemática entre la "transcripción pública y transcripción privada" presente en la novela, se comprenderá mejor si nos referirnos al hogar accidentado en que le ha tocado vivir a Nieve. 
La niña siempre habitó una hogar inestable: "A veces me pongo a contar la cantidad de casas en las que he vivido desde que nací y no me alcanzan los dedos de las manos, sigo con los de los pies" (66). Pero mientras vivía con su madre de niña, aunque hemos de suponer que se mudaran frecuentemente, disfrutaba de la bohemia de ésta: los libros, las lecturas, la música, los amigos de la madre, el benevolente padrastro extranjero. Nieve arranca con el Diario en los momentos gratos en la casa en Cienfuegos — casa "prestada por el Estado a Fausto" (13) —al borde de una laguna que da al mar, "me gusta y nado por las tardes el tramo que va desde la laguna al mar" (14).

Precisamente el mar, será una casa virtual, casa de agua, más reconfortante y quieta, que los hogares inestables de su niñez y adolescencia. Las tres zambullidas referidas en el Diario-novela darán cuenta de ello; por el momento, adelantemos solamente la primera: Soy un pez en la corriente, ella quiere arrastrarme pero me resisto $[\ldots]$ Me quedo flotando quieta, me dejo guiar al lugar en que me empuja. Soy un pedazo de bote, un cristal, una muñeca rota, un pececito de agua dulce aleteando, flotando a la deriva. (14)

La niña llega corriendo del colegio para zambullirse en la laguna, pero la madre le advierte que no le tome apego: "Mi madre no quiere que me encariñe con esta casa ni con ninguna. Vivimos prestadas, ésa es la verdad" (14).

Fue así, de la casa que compartiera con su madre, debido al divorcio de los padres, a vivir con su padre a un hogar más precario todavía. Hemos de suponer que tuvo aproximadamente, más de seis casas durante la niñez y la adolescencia: "Si saco bien la cuenta, ya voy por seis escuelas desde el preescolar hasta ahora" (115). Viéndose entre la madre y el padre, evalúa: "No es una vida normal lo que se vive con ella, pero con él 
tampoco" (77). Mucho menos que "normal”, la vida con el padre será de total

negligencia, "a mi padre se le olvida llevarme de comer" (50), abandono e insidia: "Hace tres días que no voy a la escuela. Mi padre me fue arriba y me golpeó la cabeza con la mesa. Pensé que me sacaba el ojo. Vino por detrás, sin decirme nada” (54) — refiere en tono desaprensivo.

La niña llega incluso a ser internada en un orfanato (intervalo al que volveremos más tarde), cuando, después de escapar de la custodia del padre, la madre aterrorizada por la ley que lo protege, no acepta recibirla en su casa. Para rematar, la casa inestable de Nieve se expande cuando, ya de adolescente en La Habana, como becada en una escuela de arte, también se siente fuera de lugar; así se lo explica al Diario: "si eres distinta pagas un alto precio [...] es la guerra fría, la guerra del silencio adolescente (138). Luego veremos detalladamente que la casa que compartirá con el amante privilegiado, Osvaldo, será prestada por el gobierno y no propia, resultando un cobijo movedizo y vigilado.

En la casa inestable perpetuada de principio a fin en la novela, Nieve trata de articular una "transcripción privada" que reafirme su ser "distinta", la identidad propia que le urge: "estoy harta de tararear las estúpidas canciones que todos tararean [...] y me rapo la cabeza para que entiendan que yo soy yo" (140), escribe como quien halla un asidero en afirmar su ser independiente de la masa.

\section{Problematización de la "transcripción privada"}

Como becada en la Escuela Nacional de Arte (ENA), Nieve es convocada, junto con un grupo de sus compañeros, a un encuentro con Fidel Castro. Pero los detalles de este encuentro se omiten casi por completo de Diario. En la entrada al Diario posterior al encuentro de "jóvenes intelectuales y artistas con Fidel” en que participara, Nieve 
despierta en su "barbacoa"105 habanera, en la casa que comparte con su madre. La "trascripción privada" se torna sitiada, porque la casa está atestada de amigos y conocidos de su madre, durmiendo en colchonetas, acomodándose a como dé lugar en el "primer piso" de una vivienda alterada en su estructura; el Diario pudiera ser leído por otros. La breve entrada transmite, en cierto sentido, la orfandad de la protagonista:

Desperté a mami. Le he pedido salir de la casa para hablar. Aquí no se puede. No sé si volverme a becar en la ISA. Ya no sé qué es peor. Mi casa o el albergue. Todo está oscuro porque hay muy poca luz en un apartamento que queda en el interior. Casi no me alcanza la claridad para escribir. Mami sigue dormida. Qué trabajo me cuesta despertarla temprano. Al baño no se puede entrar. No tengo intimidad, no sé lo que es andar desnuda en mi propio cuarto. Salgo a cargar algunos cubos de agua. La casa cada día se vuelve más inhabitable. (186)

El fragmento es revelador. Porque lo que Nieve, sospechando que tomado parte en un evento decisivo, quiere hablarle a su madre fuera de la casa, sin testigos, sin paredes que oigan ni vecinos cederistas ${ }^{106}$ que husmeen por pasillos y ventanas. Lo que necesita dilucidar con su madre tampoco se lo comunicará al Diario. Esta es una casa sin paredes, al menos sin la cuarta pared, porque una casa sin privacidad cae dentro de la "transcripción pública", sobre la que volveremos enseguida. En el fragmento se evidencia

\footnotetext{
${ }^{105}$ La "barbacoa", dicho en el argot popular habanero, es una construcción peculiar que ha proliferado en la ciudad de La Habana, a partir de la escasez de vivienda. La barbacoa viene a ser un falso pisogeneralmente de madera - construido dentro de las viviendas decimonónicas, aprovechando los altos puntales. Nieve duerme en una barbacoa, dentro de la "casa"—que más bien es una habitación avituallada como apartamento pequeño.

${ }^{106}$ Se les llama a los integrantes de los Comités de Defensa de la Revolución (CDR), asociación de vecinos que se organizan por cuadra, hasta hoy en día, en la Cuba revolucionaria. Los CDR forman parte del aparato opresivo del régimen.
} 
cómo la joven se siente sin lugar, desplazada en su propio hogar "inhabitable", privada de privacidad, hasta impedida de realizar sus necesidades físicas. Tampoco en su casa puede ser ella misma, no puede caminar en ropa interior, ni desahogarse.

Nunca sabremos qué realmente hubo sentido, qué hubo dicho sobre el encuentro con el máximo líder; Nieve lo refiere con evasivas: "Ha sido tremendo lo que ocurrió allí” (182). Podemos suponer que al día siguiente, después de haberles contado los detalles del encuentro a su madre y amigos de su madre que la esperaban ansiosos, Nieve sintiera un gran temor por las represalias que pudieran tomarse en su contra (en caso de que se filtrara algún informante en el grupo). Corre el año 1987 y la política cultural isleña prefigura una apertura (para recrudecerse luego), reflejo de lo que se gestaba en Europa del Este. En el marco de este "deshielo tropical" (Díaz 167), sabemos que los jóvenes presentaron quejas ante Castro: "Algunos pedían instrumentos musicales, otros contaban injusticias que se cometieron con ellos en provincia. Es como si nos pusiéramos de acuerdo para quejarnos a la vez" (182). Nos dice que estaba "angustiada por tantos problemas sin salida", pero estos detalles de la participación de Nieve quedan vedados al lector. Solo apuntes del miedo: “¿Qué nos espera? Una apertura, un holocausto o la dispersión total de todos los que allí estuvimos”(182-83).

Hemos de suponer que el Diario-novela recoge la confesión dosificada de lo que puede decirse dentro de la casa, mientras sea apolítico. Lo interesante aquí es que el Diario, siendo la "transcripción privada", esté sujeto al esperado performance de la unanimidad que, de acuerdo a Scott, es la "transcripción pública".

En la entrada "Una hora con mi madre", sabemos madre e hija se refugian en el "Parque de los Mártires" para poder conversar los pormenores del encuentro. Lo que se le 
puede decir a la madre, camufladas ambas en un parque habanero - irónicamente siendo un lugar público, pero distanciadas de testigos auditivos, lo que se confiesan allí, es lo que queda fuera del Diario. Solo llegan retazos al lector: Nieve no parece entenderse con su madre cuando ésta le advierte: "Si quieres escapar de la política tienes que escapar de Cuba" (187). Plausiblemente, la adolescente confía en que este esfuerzo negociado entre lo que se dice y lo que se omite en el Diario, es su única válvula de escape. Por lo que ha de encontrar la manera de expresar su ser, sujeta a estas presiones externas y conflictos internos. Estamos tratando de decir que en el conflicto entre decir y no decir, comunicar o no al Diario, Nieve halla un intersticio prometedor. A este punto volveremos más tarde.

Nieve reacciona a todo ello renegando de la política, incurriendo en una sinécdoque ${ }^{107}$ le comunica al Diario: "No quiero saber nada de política: me aterra lo que ocurre con la política: después de lo que viví anoche, prefiero mantenerme fuera de todo eso" (187). La sinécdoque aquí consiste en renegar de la política por no mencionar la verdadera fuente de terror; la política es la parte por el individuo todopoderoso, cuya presencia la aterrorizara el día anterior.

El diálogo manufacturado entre madre e hija produce desasosiego en el lector, transmitiendo la asfixia de los personajes, por medio de una escritura que es una denuncia lo suficientemente ambigua para confundir al censor: "no hay solución posible para mi madre", "mi madre dice que si quiero vivir sin hablar de política tengo que irme" (187), lo que hace a "hablar de política" (y hablar de política es asentir) una condición forzada, necesaria para la "transcripción pública".

\footnotetext{
${ }^{107}$ Valga señalar que la autora utiliza la sinécdoque repetidamente, entre otros recursos formales como los eufemismos, para abordar, indirectamente, ciertos temas escabrosos sensibles a la censura.
} 
Entonces la "transcripción privada" está cuartada. Por lo que resulta una extravagancia permitirse un Diario que la pudiera dejar en evidencia, en el caso extremo de ser descubierto por las autoridades. Lo problemático aquí es que el propio Diario traiciona la esencia misma de esta transcripción, cuando la narradora limita su expresión. Aún más interesante se torna la problematización de la "transcripción privada", cuando ésa otra Nieve íntima que se ventila en el texto reflexiona sobre su capacidad de adaptarse dentro de la "transcripción pública" que el sistema le exige. Scott alerta sobre cómo la complejidad de la "transcripción privada" es equidistante a la complejidad del aparato opresivo -que es ramificado (27). La "transcripción privada" ha de moldearse, adaptarse, metamorfoseare, según las presiones externas —no existiría una transcripción sin la otra y viceversa. Los artilugios compiten.

¿Qué queda entonces a la "transcripción pública”? La "transcripción pública” es la contrapartida autómata de la "transcripción privada". El individuo se habitúa a repetir la retórica del dogma sin evaluar implicaciones éticas ni las consecuencias. Nieve por no repetir calla, públicamente y en el Diario. Dice Scott:

El acto puede que se realice casi de manera automática como un ritual o acto habitual; puede que sea el resultado de haber calculado las ventajas; puede ser disimulo exitoso; puede salir de un deseo consciente de honrar a un superior respetable. Además, dado que la mayoría de los actos de diferenciación son actos rutinarios dirigidos al que sostiene un particular estatus, uno siempre puede desear una distinción entre el individuo y la actitud generalizada. (24) 
Este "disimulo" es una escaramuza, una función. Scott explica cómo la "trascripción pública" es una representación donde todos participan como actores y ninguno como público (59). Alerta sobre un aspecto conspicuo de este dilema existencial, donde el individuo no tiene solamente que enmascarar sus verdaderos sentimientos para producir el discurso "correcto". De ahí que Nieve sopese el consejo que le da su madre: “¿Pero irse a dónde y por qué? Yo sólo quiero escapar de la política, no soporto verme metida en todo esto. Algo me dice que no sé pelear es esas ligas" (188).

De acuerdo a Scott, el individuo también deberá controlar los impulsos naturales, aquellos mecanismos de defensa automáticos como la furia, el insulto, el disgusto y la violencia que despiertan las humillaciones públicas, la injusticia, las violaciones, los rituales denigrantes, la apropiación del trabajo, etc., infligidos al individuo regularmente en este tipo de sistema. Nieve/WG ha logrado interiorizar la prescripción que Scott expone: adolece de imposibilidades. A saber, en sociedades tales el individuo debe aprender a reprimir sus impulsos instintivos también. Scott lo explica así: "La inhabilidad de defenderse uno mismo o los miembros de la familia $[\ldots]$ contra los abusos del poder, es simultáneamente un asalto al cuerpo físico y la dignidad de la persona" (37). De hecho, iremos viendo que la narradora utiliza repetidamente vocablos como domesticar o entrenada para, aludiendo a ese autocontrol de los impulsos naturales que ocupa a Scott. Precisamente el bildungsroman de Nieve es la progresiva domesticación de sus instintos reaccionarios. Cuando madre e hija llegan, procedentes del interior, a La Habana en 1980, la ciudad está sumergida en el caos. Se han asilado miles de personas en la embajada del Perú, en el reparto Miramar. Como respuesta, el gobierno ha movilizado a La Seguridad del Estado, los centros de estudios, los sindicatos de trabajadores y demás 
organismos estatales para desfilar frente a dicha embajada en apoyo al sistema, dando "actos de repudio" a los desafectos hacinados allí que aspiran escapar. La atmósfera es de revuelta y violencia.

A instancias de la madre, quien le prohíbe que asista a la "violación de los derechos" de los asilados en la embajada (124), y presionada en la escuela a desfilar, Nieve tiene que elegir, optando por participar. Pero al referirlo, a pesar y a propósito de ello, desde una desarmada inocencia, el discurso se desdobla en denuncia:

No sé qué hacer, mami me prohibió ir a los "actos de repudio", esos que le hacen a los que se van del país [...] la gente tira huevos, tomates y piedras a las casas de los que se van [...] A veces hasta arrastran por el suelo a los que se van [...] Están igual que mi padre, golpes y golpes sin dejar que uno pueda ir a donde quiera [...] Mami no entiende que en la escuela no me dejan decir que no. (123-24)

Integrándose al desfile violento orquestado por otros, camuflada en la turba y escurriéndose fuera de estos "actos de repudio" en medio de la euforia colectiva, la adolescente participa del engranaje del poder. La atmósfera de horror y represión sobrepasa la resistencia de la adolescente: "Golpearon a un hombre hasta sacarle sangre y los niños los tienen arriba, en el edificio, sin comer. Le cortaron el agua y el gas. El hombre salió a buscar comida y lo agarraron. Desde por la madrugada están dándole y gritándole sin parar” (125), refiere. 
En la lucha por la supervivencia, dentro del dispositivo mismo del poder, constantemente se intercambian los papeles. El propio padre de Nieve se asilará en la embajada y partirá rumbo norte, renunciando a su carné del Partido Comunista ${ }^{108}$.

Llegan ecos de Michel Foucault cuando alerta sobre cómo el poder no emana de un solo lugar, sino que se interioriza, convirtiéndose en una disciplina ${ }^{109}$. El poder se pulveriza en la realidad cotidiana y alcanza al ámbito privado, las mentes de las personas. Nieve, dentro de la "transcripción privada" se autodisciplina por miedo al castigo: "Me siento perdida [...] Sé demasiado" (184). Pero confesará su miedo repetidamente: "Me siento aterrada", y se desentiende de lo político para insertarse en la supervivencia del día a día: "Es mejor vivir sin mucha conciencia de lo que pueda ocurrir" (176). Para Foucault el poder se desplaza de la cúspide, se institucionaliza, se interioriza, se convierte en mecanismo de supervivencia, en mecanismo de poder. Los individuos se convierten en "multiplicidades" del poder (148).

De modo que el poder en el contexto que nos ocupa, estará dado en las organizaciones de masas, progresivamente domesticando a Nieve: en los Pioneritos donde Nieve hubo que producir un discurso político para pasar el curso escolar, en los Comités de Defensa de la Revolución vigilantes de las sucesivas casas inestables de la niñez, en la escuela de arte en que está de becada la adolescente, en los mítines de repudio en los que se ve obligada a participar, en los sindicatos obreros que envían a su

\footnotetext{
${ }^{108}$ En Miami lo esperan sus padres, que son los abuelos paternos de Nieve (TSV 129).

${ }^{109}$ En un momento después del siglo XIX se crea estas disciplinas sociales que terminan siendo interiorizadas. Foucault echa luz sobre la relación entre el poder y el control que este ejerce sobre el discurso, creando mecanismos casi perfectos para eliminar la crítica, desacreditar opiniones adversas, e interceptar la información que ponga en peligro o en duda su hegemonía. En Discipline \& Punishment, véanse las páginas 145-51.
} 
madre a una guerra internacionalista en Angola, en las movilizaciones laborales que llevan a su padre a enseñar teatro al interior de la isla, etc. En términos de Foucault, Nieve se vigila a sí misma, se mide frente al poder. El poder alcanza así la "transcripción privada" de Nieve. Apuntemos que, en lo que respecta al individuo, el poder se hace dócil, incorporado, siendo el poder en sí, el poder que se tiene de no poder: "Nosotros vivimos entre lo prohibido y lo obligatorio" (137), dice. Además, para el Diario-novela existe un potencial público-lector incierto. Visto así el Diario de Nieve (Diario-novela de WG), es cuerpo dócil incorporado a la mecánica del poder.

\section{Desde un análisis feminista: "Trascripción privada" como discurso disidente}

Se impone un análisis feminista, siendo los parámetros del poder en Cuba políticamente patriarcales (productos de una tradición machista y falocéntrica), y la emisora del discurso una adolescente que se enfrenta a la adultez haciéndose de un discurso alternativo. Desde la imagen mariana que encabeza el Diario-novela, queda representada la literatura (femenina) como ofensiva al poder. Entonces, veremos que el discurso de Nieve es disidente en cuanto a que: 1) La emisora, Nieve, es mujer y por serlo es doblemente hostigada. 2) La "transcripción privada" está asediada y Nieve reacciona de dos maneras contradictorias/complementarias: se resiste y se doblega al poder. 3) Su discurso (el discurrir del Diario), se define en relación con el poder. Ileana Fuentes ${ }^{110}$ en su ensayo "Pluralismo y feminismo para una agenda cubana"111 alerta sobre este punto: "El feminismo plantea que la tradicional exclusión de la mujer de las esferas donde se planifica y conceptualiza el rumbo de una sociedad, es la

\footnotetext{
${ }^{110}$ Incluido en Cuba sin caudillos. Un enfoque feminista para el siglo XXI (1994), de Ileana Fuentes.

${ }^{111}$ Fuentes, op. cit. (69-80)
} 
razón fundamental de que se perpetúen las dictaduras" (76). Fuentes plantea un paralelo entre los medios de coacción y retracción del discurso disidente en una sociedad totalitaria, y aquellos métodos represivos que impusiera el Santo Oficio inquisitorial:

El absolutismo se extiende a través de los siglos y permanece intacto. Es fácil ver el paralelo entre el credo teológico y el credo secular: religión y dogma, por ejemplo, se convierten en ideología política, en partido único. $\mathrm{Al}$ igual que el pontífice en sotana [...] o en uniformes militares, ejercen el control absoluto sobre el pensamiento de sus súbditos. (Cuba 73-74)

La autora llama "inquisiciones seculares" al proceso de domesticación del individuo, presionado al punto de renunciar a su individualidad en pos del colectivo que soporta el poder. En lo que se refiere al discurso, la herejía o/y disidencia se trocará en su opuesto, sumisión y soporte, luego el mea culpa o/y la renunciación. Becada en la escuela de arte, Nieve sabe que debe adoptar los modales y el comportamiento colectivos: "Si no eres parte del grupo [...] te rechazan" (138). Tan moldeada al colectivo se muestra, que la madre llega a apodarla irónicamente "la hija del porquero medieval" (138), refiriéndose a los malos modales que la hija ha adquirido en dicha escuela.

Como requisito para estar becada, debe uniformarse y entrenarse en una academia militar o atenerse a las consecuencias: "si no voy me sacan de la escuela" (148). Allí simulará con sus compañeras defender al país de un enemigo que ella no reconoce: "Nosotros encerrados en este cerca, aprendiendo a matar a alguien que aún no sabemos quién es" (154). Causalmente, el destacamento de adolescentes hembras es comandado por un sargento que las hostiga impunemente. 
Fuentes explica que mientras el poder inquisitorial era expresamente misógino, el régimen cubano, a todas vistas patriarcal y falocéntrico, excluye a la mujer relegando su papel en la sociedad a un plano supeditado al hombre o nulo. Nieve toma nota de ésta desigualdad de género: "Aquí uno cumple los deseos y caprichos de alguien, supuestamente superior a uno, que tiene ganas de medir fuerza con las mujeres o los seres sensibles que le rodean" (157). Fuentes arguye que la sociedad cubana no sustenta un discurso femenino, por lo que la voz de la mujer es prácticamente inexistente, y Nieve, impedida de articular públicamente un discurso propio, se esconde para hacerlo: "Escribir el Diario en la escuela delante de todo el mundo ni pensarlo. Ando siempre escondida con la libreta" (139). Nieve ha de aparentar que es parte del colectivo, por miedo a las represalias, se autodisciplina por temor al castigo: "Pudiera ocurrir que me votaran de la escuela" (139). Su función dentro del sistema, que a un tiempo la educa en arte y la entrena para la guerra, es meramente instrumental en el sostenimiento del poder: "No puedo ser distinta en este mar uniformado" (157) — se instruye.

O, en el mejor de los casos, el discurso disidente es remplazado por un discurso "indirecto", parapetado, donde la disensión se acomoda tenue, oscilante, ambigua: "Estoy harta de tratar de parecer una más" (140)—se queja. Es ésta una "trascripción privada" en conflicto. A esto se debe que Nieve apele frecuentemente a su ignorancia sobre el funcionamiento del sistema; aunque cierta ironía en el uso de los términos militares nos alerta de lo contrario:

Toda esa carga la lleva mi cabeza y si la vierto en Diario es para aliviarme, para intentar postergar lo que no comprendo. Por eso siempre vuelvo a él. 
Aunque quiera dejar de escribir al final regreso; ese es mi "túnel popular", mi "refugio de guerra", mi escondite secreto, mi verdadero confesor. (184)

Pero anotemos que el ser que nos ocupa es doblemente amenazado, no sólo por vivir en una sociedad tal descrita aquí, sino también por razones de género, en tanto que el poder esté en manos de hombres. En el Concentrado Militar, Nieve y sus compañeras se cuidan de un teniente deleznable que abusa constantemente del poder que tiene sobre ellas: "Nos llenó de amenazas, bromas groseras, usó toda la táctica de la indecencia con nosotras. El pelotón de mujeres es su preferido, nos lo cantó clarito, clarito" (156). Tanto así que las golpea y manosea deliberadamente: "Lucía se rebeló al teniente Rolando y le dieron tremenda zurra en el cubículo de los oficiales. Ella y el teniente solos allí, sin que pudiéramos hacer nada [...] El teniente es una animal, Lucia está llena de cardenales por todas partes" (173-74) —apunta en su denuncia tácita.

Nieve, junto a sus amigos Lucía y Alan (personaje socialmente "conflictivo" que terminará yéndose del país, como veremos más adelante), será llevada a un Consejo Disciplinario, especie de juicio inquisitorial, por hallársele escondidos en su litera, una radio de baterías y un libro de un escritor prohibido (proveniente de la biblioteca secreta de su madre). El libro prohibido que Nieve presta a Lucía —nieta del autor "prohibido" en cuestión — será la causa fundamental por la que expulsen a los tres amigos del Concentrado Militar.

Presentado ante la hoguera del Siglo XVI o el paredón de fusilamiento del Siglo XX, el sujeto se ve obligado a producir una confesión o retractación del discurso disidente del poder. Hoy en día en Cuba, como otrora, la confesión "voluntaria" se obtiene a través de la tortura o el chantaje; dice Nieve refiriéndose a Lucía: "Está lista 
para morir quemada en la hoguera, pues por supuesto diría que era la dueña del libro" (177) (la itálica es nuestra). Proceso de contrición individual que viene a ser una condensación de la maquinaria opresiva que, a mayor escala, es sometida toda la sociedad: "Me siento aterrada, tengo un pánico de que se les ocurra mandarnos para una escuela como la de Cruces, de esas que reforman a los adolescentes" (176). El libro en cuestión, secularmente, será quemado por el teniente tenebroso delante de todas las muchachas.

Pero además de la Nieve aterrada, está la Nieve impertérrita que mide fuerzas con el poder: Nieve es disidente del discurso del poder por compartir un libro prohibido, y por traer una radio prohibida al Concentrado Militar. También por otra culpa secreta: llevar un Diario que da cuenta de este régimen.

En este contexto, el "ser femenino" particularmente desestimado y excluido del poder en Cuba, es doblemente hostigado, avasallado y anulada su individualidad como cualquier ciudadano común dentro del sistema, y más aún como ciudadana de segunda categoría debido a su condición de mujer ${ }^{112}$. Nieve es consciente de que lo escrito en su Diario pudiera acarrearle castigos graves. La represalia contra los que se atrevan a cuestionar este orden, desde la escritura, la constata así:

Hace unos meses encerraron a unos poetas de Matanzas. En medio de un recital le quitaron la luz a la casona y la golpiza fue tremenda. Se dice que

\footnotetext{
${ }^{112}$ Fuentes ofrece estos datos: en el año 1994, después de más de 30 años de Revolución, el $80 \%$ del gobierno cubano estaba compuesto por hombres: el 18\% de mujeres en el Comité Central del Partido Comunista, el 12\% en el Buró Político, el 13\% en el Consejo de Estado; el 0\% en el Consejo de Ministros Cifra que se ha mantenido estable antes y después de esta fecha. Hace notar que la marginación del cubano por concepto de raza y sexo, durante el actual régimen se ha extendido a otras categorías de exclusión por razones ideológicas y religiosas (58-59).

Nótese que no necesitamos actualizar los datos porque el contexto de WG/Nieve precisamente responde a este censo verificado por Fuentes.
} 
es una represalia por la sinceridad de lo que escriben. Hasta una conocida y respetable escritora, Carilda Oliver Labra, fue golpeada en el intento de silencio. (183)

Así mismo, la adolescente da cuenta de una lista de prohibiciones impuesta a la madre, y comenta:

Prohibido poner a Carlos Varela por la canción que estrenó en el programa de mi madre. Parece que la palabra "libertad" la dijo de manera que molesta [...] Para ella es un honor ponerlo y arriesgarse, pero por ahora hay que estar quietos. Dentro de un mes lo vuelve a intentar y así va midiendo fuerzas. (165)

Madre e hija, desde sus contextos, midiendo fuerzas con el régimen y la censura generalizada, se definen en relación a ese poder al que disputan una voz divergente. Lo que explica por qué se ha hecho necesario un análisis feminista de TSV:

1. Porque consideramos que la tesis de Fuentes es fundamental (novedosa y aún pendiente $)^{113}$ para entender el legado sociocultural que conforma la psiquis colectiva cubana, cristalizada en la Revolución y su sistema de "Estado falocrático" $" 114$. La tesis de Fuentes sostiene que: "Desde la neutralidad sería imposible descifrar los patrones conformados en el contexto de ideologías específicas, como son el patriarcado secular y el teológico, o el esquema esclavista y sexista del poder (75)". Tanto así que para

\footnotetext{
${ }^{113}$ Resulta sintomático que el análisis de Fuentes - prácticamente desconocido, siga siendo una agenda pospuesta en las propuestas de nación que se producen en Cuba (lo cual es más predecible) y en el exilio. Este es un libro que consideramos fundamental a la hora de explicar el fenómeno social cubano, porque analizando las inequidades, propone soluciones inclusivas, justas y representativas para que la democracia sea posible. Lamentablemente, su poca divulgación se debe al hecho de que el libro tiene una única edición de 1994 y está agotado. (Estos datos los hemos confirmado personalmente con la propia autora.)

${ }^{114}$ Fuentes, op. cit. (43)
} 
comprender a Nieve, habría de desmontarse esa psiquis colectiva totalizadora que castra su individualidad: "No entiendo nada, pero dentro de este circo sobrevivo" (139).

2. Porque para Nieve siempre existe una figura patriarcal que la oprime, desde el padre abusivo, el teniente que la manosea, el amante privilegiado y controlador, hasta la figura del máximo líder que la aterrorizara en la referida reunión con los estudiantes de arte.

Remontémonos a la niñez de Nieve, y comprobemos que desde un principio, los dos planos de su realidad, el privado y el público, están dominados por hombres: su padre, el teniente, el amante, el máximo líder. La madre también se presenta disminuida, supedita a la voluntad masculina: "Mi padre siempre termina pegándonos" (15). Es una madre amorosa, enajenada y sensible, que por momentos cuestiona el poder, pero es psíquicamente frágil, físicamente débil, temerosa del padre, y del gobierno que llega a enviarla a una misión internacionalista a Angola en contra de su voluntad: "Mi madre me dice que esta guerra no tiene explicación, pero me pide que no lo repita" (17).

La niña de nueve años (y la adolescente, hacia la segunda mitad del libro), se identifica con la madre, hasta el punto que le produce lástima su desamparo, su debilidad de carácter: "Mi madre tiene más miedo a las cosas de afuera que yo" (19). Ya divorciados sus padres, la niña será la manzana de la discordia entre ambos progenitores. Temerosas madre e hija, resisten las embestidas del padre. Así es que desde muy niña Nieve se ve enfrentada al poder que el padre abusivo y bebedor ejerce sobre su madre y sobre ella, hasta el punto de arrebatarle a la madre la custodia legal de la niña.

El padre se la llevará a vivir con él al campo, en El Escambray, la zona oriental de la isla, alejándola de Cienfuegos (de la madre y el esposo sueco de ésta), al otro extremo 
de la isla. Allí compartirán la misma cama. El padre impone un régimen de terror del que la niña dará cuenta en el Diario: "Yo estaba asustada, cuando toma cambia completamente" (45), "solo puedo escribir cuando mi padre no está" (41), "me da miedo" (43), etc. Al parecer el padre surte el mismo efecto en otras mujeres: "Hay una mujer que quiere ganarse mi simpatía, seguro que anda con mi padre. Pero le tiene miedo como yo. Me saluda bajito y se va corriendo" (39) —apunta.

La vida con el padre es referida desde una distancia narrativa lacerante: "Otra vez me pegó, pero en la cara y no tan duro [...] mañana cumplo nueve años" (57); da cuenta del abandono al que la somete: "No me ha dado de comer" (48). El progenitor impone una tiranía casi perfecta, paralizante, desde el principio — habrá rigor y distancia:

Mi padre no piensa hablarme sobre el problema, sobre el juicio, sobre los días en que me puedo ir con mi madre. Todo ha sido en silencio. Quise escribir en el carro y me quitó la libreta [...] No le gusta el Diario, por eso lo tengo escondido. Mi padre me llama por mi apellido. (39)

No obstante, frente al poder inapelable del padre, la niña se atreve a tomar nota de un evento perturbador $-\mathrm{y}$ busca la complicidad del lector, que citamos en parte porque da la medida del abuso psicológico y físico con que se impone el padre. Reparemos en la objetividad narrativa de las entradas del Diario durante el periodo que vive con su padre; junto con el hecho de denunciarlo, aunque solo sea desde las páginas de su Diario escondido - lo que hemos apuntado como resistencia al poder (desde el ámbito privado equidistante al contorno público):

No sé si escribir esto en el Diario. Me da miedo, no puedo decírselo a nadie, por favor, guarda el secreto. Mi padre se acostó con una mujer en 
nuestra cama. Salió del cuarto y me puso de pie, castigada en la mampara que da la baño. Vi cómo hacían de todo, no podía moverme [...] gritaba muy alto. Yo quise irme pero mi padre se levantó y me quedé recta como el asta de la bandera $[\ldots]$ me dio miedo quedarme mirando $[\ldots]$ cerré los ojos varias veces. Cuando por fin se acabó mi padre entró en el baño y me arrastró hasta la ducha. Corrió la cortina y con el chorro de agua abierta me dijo que nunca confiara en ningún hombre $[\ldots]$ me tocó el pelo y salí corriendo empapada. (43)

Lejos de la madre (y el hogar feliz, aunque inestable, que ella propiciara), le irá mucho peor. Al padre se le olvida alimentarla, la golpea frecuentemente hasta hacerla sangrar, la atemoriza todo el tiempo — como en la escena citada arriba. El discurso disidente del poder patriarcal queda referido en el Diario, la niña está aterrada: "Cuando entro a la casa estoy más en peligro que cuando estoy afuera. Llegando me da el salto en el estómago y empiezo a temblar" (66). Aprende a sobrevivir contrariándolo lo menos posible, y como sucede frecuentemente en las relaciones abusivas, sintiéndose en parte merecedora del castigo: "[...] porque siempre uno hace algo mal. Por eso me pegan" (58). A la merced de una vecina que se apiada de ella, dándole de vez en cuando de comer y curándole las heridas, recurrirá al Diario como refugio y desafío oculto: “Solo puedo escribir cuando mi padre no está" (41). Paralelamente intentará encajar en el engranaje político (la "transcripción pública") de la escuelita de campo a la que le toca asistir -microcosmos de lo que se gesta en el país.

Finalmente, logrará deshacerse del padre fingiendo una golpiza (debido a que las golpizas reales la dejaban demasiado debilitada para reaccionar), y será devuelta a 
Cienfuegos con la madre. En este punto la madre, perennemente aterrorizada por el poder, se siente incapaz de recibirla por miedo al derecho legal del padre. Por lo que será internada en un "Centro de Reeducación de Menores", que también es un "Centro de Depósito Infantil" u orfanato. A la niña la ubicarán del lado de los huérfanos o abandonados. En este punto Nieve anota una apreciación de su madre: "Me doy cuenta que siempre ha sido muy cobarde y con ese miedo más nunca estaremos juntas" (90). La niña rechaza el miedo de la madre, sin embargo, el mismo miedo irá permeabilizándola, creándole una costra dura, protectora -cumpliéndose la dialéctica entre opresor y oprimido.

La oprimida (Nieve) repetirá los mismos patrones a la hora de escoger novio opresor (Osvaldo). Hemos de aclarar que el novio dista de ser lo abusivo que fueran el padre o el teniente del Concentrado Militar; pero así y todo responde a la figura patriarcal que deseamos destacar. Cuando Nieve, ya estudiante en la ENA (que es la misma escuela de arte, pero para graduados del Instituto), se va a vivir con Osvaldo, el amante pintor, a una casa en Nuevo Vedado, deja a su madre contrariada por su decisión. La madre argumenta que el novio no es un verdadero artista, despreciando el tipo de vida privilegiada que obtiene con la venta de sus cuadros en el extranjero, apelando a una autenticidad que se pierde en esa vida de privilegios: "La pintura es otra cosa" (223), le dice rompiendo uno de los dibujos de Osvaldo que la hija le trae como regalo.

Con Osvaldo mantendrá una relación ambigua, sobre la que regresará una y otra vez en el Diario. Con él se siente "atrapada en un lugar de otro mundo" (206), pero también protegida dentro del sistema, y excluida de la estrechez que compartiera con su madre. Empero, en casa de Osvaldo Nieve también se siente fuera de lugar. No puede 
expresarse libremente, sus comentarios y preguntas resultan incómodos para Osvaldo y los amigos de éste: "Yo, como no existo, no hablo. Cuando intento opinar Osvaldo me abre los ojos" (221). De modo que su pareja repite las consabidas fórmulas sexistas que desde el podio gobierno encarna el máximo líder, y que chocan con el espíritu participativo de la joven. $\mathrm{Y}$ este fondo privado es el microcosmos de la realidad social que vive Nieve ${ }^{115}$, donde se es libre de no elegir: "Osvaldo me enseño a elegir, a elegir cualquier cosa que me diferenciara de los demás", al tiempo en que dice: "fue buscando varias piezas para armar un nuevo ajuar para la nueva Nieve” (217). ¿En qué estamos? ¿Osvaldo le enseña a elegir, eligiendo por ella?

Nieve cae en la trampa de el poder de no poder uniéndose a Osvaldo. Comprobamos que la proyección del ser Nieve al margen de esta circunstancia que consistentemente la niega, se hace inminente como escape de las prohibiciones y el asedio. Afirmándose por oposición al poder que se ejerce sobre ella: "Ésa no soy yo. Si así son las cosas, me veo muy mal” (218). Nieve se siente excluida -no solo socialmente inepta, sino también como la mujer frente al poder del hombre (poder que ella ha aceptado otorgarle): "Descalificada" — concluye.

Dos exclusiones que según Fuentes van mano a mano: exclusión por ineptitud (dentro del sistema patriarcal), y exclusión de género (Fuentes 66). La figura del padre abusivo se repite, dosificadamente, en Osvaldo imponiéndole prohibiciones. Como el padre Estado, la vigila, husmeando en su Diario:

\footnotetext{
${ }^{115}$ Recomendamos una lectura fundamental para comprender la realidad cubana bajo el régimen castrista es Cuba sin caudillos. Un enfoque feminista para el siglo XXI (1994), de la feminista Ileana Fuentes, que ya hemos referido. Fuentes explica como la historia de Cuba está escrita desde el incuestionable yo patriarcal, y cómo el país es conducido por un líder patriarcal con una agenda monolítica, uni-sexual y uni-racial, que no da espacio a la mujer.
} 
Ahora Osvaldo, como mi padre me prohíbe el Diario. Leyó todo lo que pienso de sus amigos, descubrió las opiniones de mi madre sobre él y se enfureció [...] El machismo en Cuba está disimulado por la alta instrucción, pero ahí está, amenazándote todo el tiempo [...] mi padre y Osvaldo odian mi Diario. La historia se repite en ciclos que regresan para recordarme que nunca he sido mi propia dueña. (224)

Lo que prueba nuestra tesis de que el Diario sea el intento de plasmar su ser, la fuga auténtica del ser Nieve, sintiéndose coartado por el opresor bicéfalo, polimorfo: el régimen patriarcal y el novio machista (novio que vino a sustituir la figura del padre). Uniéndose a Osvaldo, Nieve vuelve a caer en manos del poder patriarcal (incluso hasta mucho después que éste se haya marchado a Europa, para no regresar). Escribe entradas en el Diario apresuradamente y a escondidas: "Hay mucha pasión y desborde en cada cosa que me ocurre, pero no hay tiempo para narrarlo porque la censura aparece siempre con cada hombre que me cruzo en el camino" (224).

Dentro de la mecánica el poder de no poder, Nieve se ve "atrapada", pero escoge esa vida de privilegios — cubrir sus necesidades básicas: "Saboreé aquella leche pura, cremosa; desde hacía años no tomaba algo semejante. No quisiera comparar su vida con la mía, sería terrible" (208). Aunque sabe que de algún modo escapa de la realidad social más crudamente autoritaria, a otra menos expuesta pero igualmente opresiva. A pesar de que se embarca en arduas discusiones con su pareja (cuyos detalles omite), se siente protegida por el estatus privilegiado del que disfruta Osvaldo, y la autoridad que le da ser un pintor que trae divisas al gobierno. Confiesa: "Me escapé a esta cúpula aséptica, donde intento esconderme para no sentirme en peligro" (226). La huida — lo que ha sido un 
anhelo constante — parece materializarse: "Espero que Osvaldo pueda sacarme muy pronto" (235). Según refiere, Osvaldo tendrá intenciones de casarse con ella y llevarla a París después que cumpla 18 años, y ya no tenga que depender del permiso del padre. Lo que ilustra literalmente el traspaso de poderes patriarcales: “Ayer cumplí 18 años [...] En un mes estarán los papeles resueltos y Osvaldo vendrá a buscarme" (245). Pero Osvaldo nunca regresará por ella.

El tercer punto de este análisis desde el prisma feminista, se refiere a que Nieve se mide a sí misma con respecto al poder. Y el poder — se ha visto — es patriarcal y falocéntrico, ejercido por un Estado falocrático ${ }^{116}$. A WG debe enmárcasele dentro de un grupo amplio de escritoras cubanas, que en palabras de Madeline Cámara, de distintas generaciones, estilos y orilla, "se han convertido en 'Las retadoras', mujeres que desde la posición de la escritura subvierten los lugares patriarcales, sus variadas expresiones dentro de la política, las relaciones familiares, interpersonales, etc." ${ }^{117}$. WG subvierte los lugares patriarcales desde la novela —el padre y el Estado patriarcal. A pesar de la amenaza: "Mi padre siempre nos pegaba" (TSV 15) —apunta. No dejará de tomar nota, retando el poder del padre desde el Diario.

En sus apuntes no se tiene lástima. Después de una riada violenta del padre, donde este somete a madre e hija a insultos y golpiza, en la cual incluso el padrastro "sueco" sale golpeado, la niña apunta, distanciándose emocionalmente de la barbarie: "Mi madre parece una niña. Está llorando. Yo me siento mayor que mi mamá” (16). La madre se

\footnotetext{
${ }^{116}$ Véase Cuba sin caudillos, página 43.

${ }^{117}$ Cámara acuña a la generación de "Las retadoras", e incluye a escritoras ya enmarcadas dentro de Generación 'periodo especial', dentro de cuyo prisma también cabría enmarcar a WG. Véase en "Antología y estudio de Ena Lucía Portela", artículo de reseña para una antología de cuentos de Portela, publicado en El Nuevo Herald, el domingo 18 de abril de 2010.
} 
permite llorar, pero la niña no, y esa desafección emocional ante el daño que se les inflige la protege.

Más adelante, cuando amenazan a la madre con enviarla a la guerra de Angola en misión internacionalista, la niña angustiada anota que teme que pueda "morir de cualquier cosa, es muy pequeña, casi como yo, calza mi mismo pie y usa mis medias. No va a aguantar esa guerra” (18). La madre será enviada como reportera de guerra, permaneciendo en África seis meses, y la niña en su honor dejará una página en blanco en el diario (19). Luego notamos del subsiguiente lapso de silencio de seis meses de apuntes, hasta que la madre regresa enferma. El gesto simbólico, por un lado alude al vacío dejado por la madre. Por otro lado omite la amalgama de sentimientos contrarios a la imposición; misión bélica antípoda a todo lo que madre, que es una especie de hippie pacifista, e hija, desearían hacer con sus vidas -en caso que se les permitiera elegir. La página en blanco es duelo, es todo lo que no puede decirse, es la nulidad del ser, en cuanto a que el padre Estado decide por ellas.

El Diario destila la relación de la protagonista con el poder. Nieve se excluye del discurso heroico: "No necesito ser rebelde para demostrar que no he salido de un molde férreo $[\ldots]$ no tengo interés ninguno en ser valiente. Estoy descansando de eso" (142143). Nieve esconde su Diario. Reta al poder, pero lo hace por medio de artilugios, a veces desde omisiones que desconciertan — por la que en determinado momento será emplazada ${ }^{118}$. A veces apelando a una inocencia púber:

\footnotetext{
${ }^{118}$ El personaje Antonio le exigirá que ahonde en las emociones y revele las omisiones obvias, que escriba "la verdad". Consúltese la entrada 21 de abril de 1990 (TSV 264-85).
} 
Me explicó que los presidentes se cambiaban cada cuatro años aproximadamente. Mami se escandalizó cuando le confesé que yo pensaba morían como los reyes, luego venían sus hijos o hermanos y seguía la familia gobernando eternamente como sigue la tradición del escudo, la bandera y el himno. (157)

Otro ejemplo de donde Nieve medirá fuerzas con el poder, lo hallamos también en el "Diario de adolescencia". Esta parte del relato (que ya abordamos aquí desde otro ángulo), establece una extraña simetría en nuestra investigación, donde la escritura de WG tiende un puente a la CI, cuando Lucía, la amiguita de la protagonista, parece ser la nieta de éste último, apareciendo aquí como escritor exiliado, un tal "López Durán":

[...] fue enviado como encargado cultural cubano a un país de Europa a finales de los sesenta y se quedó (todo el mundo se va). Entonces publicó novelas muy duras sobre el problema de Cuba y aquí está prohibido vender sus libros y leerlos. Si lo agarran a uno con eso en las manos, ya tu sabes. (163)

Recordemos que Lucía, viva estampa del miedo ${ }^{119}$, nieta del escritor exiliado célebre $^{120}$, recibe una golpiza de manos del teniente, "teniente Rolando", en el Concentrado Militar donde las adolescentes reciben entrenamiento. Nieve refiere la quema del libro que le encontraron a Lucía y que ella le había facilitado a su amiga: "La noche de ayer fue muy triste: quemaron el libro de López Durán delante de todo el

\footnotetext{
${ }^{119}$ Nieve describe a Lucía como "una de esas pobres rubitas. Está más bien traslúcida. Tiene las uñas comidas hasta las carnes, unas ojeras moradas y tiembla mientras habla" (TSV 161).

${ }^{120}$ Queda entredicho que Lucía es la nieta de Guillermo Cabrera Infante; siendo CI, contenido en TSV, uno de los tantos que se fueron.
} 
mundo" (173). Precisamente Nieve concebirá y presentará para su graduación una obra controversial que mide fuerzas con el poder; apuntando a la censura de libros, construirá piras con ellos:

He fabricado enormes estructuras de libros, algunos forrados y otros no. Las estructuras semejan gigantes que serán quemados el propio día de la inauguración en el patio de la escuela. He forrado casi mil libros [...] Sólo resta encenderlo. (239-40)

Notemos que quema libros de "marxismo", "ciencias políticas", "comunismo científico" y cualquier cantidad de temas, junto a libros "forrados" — que son los libros censurados que se pasan de mano en mano camuflados. Y aunque omite una reflexión sobre su obra, el hecho de atreverse con ella ya es significativo. No obstante reconoce que con su obra: "voy quemando mis naves y todos imaginan que no estaré en Cuba para empezar el primer año" (239).

El Diario de Nieve ha de comprenderse como un desafío al poder. En ese sentido, refiere una variada gama de medidas represivas por parte del gobierno: la censura, la quema de libros, las reprimendas, el mea culpa, las golpizas ${ }^{121}$, los consejos disciplinarios, los interrogatorios, el expediente — especie de carpeta acumulativa que se le abre a la persona desde niño y que le acompañará hasta la adultez, donde se da cuenta

\footnotetext{
${ }^{121}$ El Diario da cuenta de varias golpizas por parte de las autoridades. Sabemos de la golpiza a Lucía, amiga de Nieve, de manos de un militar de segunda categoría, y las golpizas a los disidentes durante las revueltas que llevaron al éxodo del Mariel -referidas ya, así como la golpiza al cantautor Carlos Varela (TSV 182-83).
} 
del comportamiento del individuo ${ }^{122}$. De hecho, la palabra censura aparece repetidas veces en la novela:

Las personas están llamando para dar sus opiniones. Pero yo sé que esto es grabado: no pueden sacar a la gente hablando así como así, hablando sin censura. Me conozco las emisoras como la palma de mi mano. Mi madre hizo un pacto con el viento porque a la radio se la lleva el aire. (169-70)

También hallamos referencias a la censura en las páginas165, 173, 179, 177 (donde tilda a los censores de "mediocres"), en 173, 156 (donde da cuenta del "seguroso", agente de la Seguridad del Estado que las acosa). Da cuenta así de la censura de músicos, de libros, etc. Pero la manera más lacerante de ser presentada será quizás la censura en su modalidad autoinfligida. Recordemos que Nieve se autocensura hasta cuando le hace "los cuentos" a su madre, por no verla sufrir.

Sintomática es la confesión que apunta Nieve en el Consejo Disciplinario, donde se trifulca su autodefensa y la de sus amigos, tratado de evadir el castigo, en un desgaste de la verdad y de los hechos donde el ser se sabe entrampado:

“Communication breakdown." Se rompe la coherencia cuando uno tiene que inventarse historias para defenderse. Como si no bastara con la realidad. Nos obligaron a combinar la verdad con la mentira. Porque así crecimos, ocultando los libros, las ideas, los parientes. A estas alturas, ¿qué importa mentir o manipular la realidad? Un hombre que le pega a

\footnotetext{
${ }^{122}$ En la Cuba socialista (como en otrora bloque socialista) se abren "expedientes" para todo: Un expediente de estudiante, un expediente de militante del Partido, un expediente de trabajador, de agente de la Seguridad del Estado, expediente de arresto, etc. La acumulación de estos expedientes es el registro total del individuo que ha de someterse a "verificaciones" en las cuales se examina el "expediente", ya sea para obtener un empleo, ya sea para solicitar un permiso de salida del país.
} 
una mujer es también capaz de violarla. Alguien como el teniente puede ser en verdad un monstruo [...] “¿Dónde está el enemigo entonces?” ¿El enemigo es el abuelo de Lucía que escribe los libros que nos han prohibido leer, o el teniente Rolando que desahoga su violencia en nosotros? (179)

La pregunta penúltima es capciosa. Apunta a una dependencia ideológica cifrada de un enemigo inventado, según Rafael Rojas, fundamento mismo de la sociedad:

El enfrentamiento a los Estados Unidos se ha convertido, para Cuba, en una nueva forma de dependencia. El gobierno cubano depende de la "amenaza del imperio" para conservar algo de su legitimidad [...] El poder de la isla sabe que la Revolución vive de la "hostilidad" de los Estados Unidos. (Rojas, El arte 92-93)

Desde que empezara a desmoronarse la URSS hasta su disolución en 1992, la isla pierde su principal aliado político, económico y militar, y el gobierno, que se niega a los cambios, se afinca postulando "amenazas" externas que ocupen a los cubanos en una situación límite. Este contexto es importantísimo para comprender la huella en la Nieve $^{123}$ que dejan estas preguntas sin respuestas. La represión recrudece, la disidencia ha de ser sofocada, "las escisiones internas son inadmisibles" (Rojas, El arte 92). Entonces la denuncia directa se arredra ante la premura de la supervivencia-la adolescente intuye que ha de callarse para sobrevivir dentro del sistema.

\footnotetext{
${ }^{123}$ La itálica es nuestra. Quisiéramos recurrir más de una vez a esta metáfora nuestra (que juega con el nombre de la protagonista), para señalar el rastro de su acción individual.
} 
Otro ejemplo relevante de resistencia al poder es la intrusión ilegal de Nieve en una embajada extranjera, en el barrio de Miramar: "La guardia militar de la casa estaba atenta, la caravana de carros ilustres se alargaba sobre la hierba deshecha" (204). El tono cándido en que es referido, contrasta con lo exorbitante de lo narrado. El caso es que la adolescente Nieve trepa un par de muros aledaños, escabulléndose por la parte trasera, y se zambulle, por una hora, en la piscina de una residencia oficial, llena de invitados, donde ocurre una fiesta. La mansión, naturalmente, está vigilada por guardias militares armados que ella logra evadir. Hallando en la trasgresión un placer que le es negado: Me quité todo de una vez y me quedé desnuda, me miré tranquila como Narciso, en aquella silenciosa transparencia. Titubeé un poco, pero al final rompí el espejo de agua y bajé, bajé, bajé, aplazando el mundo con los ojos, aplazando la escuela, la madre, la casa, la pobreza y mi vida para después. (205)

La zambullida — segunda sumergida de las tres que hemos prometido abordares momentáneamente liberadora por transgresora, ya que ocurre en el mismo vórtice del poder político, en una fiesta donde se ha dado cita la élite diplomática. Pero aún sabiendo las consecuencias que esta acción pudiera acarrearle, Nieve logra deslizarse por una fisura del poder, y sin pedir permiso: "Me quedé como una hora en el fondo limpio, respiré como un pez desnudo $[\ldots]$ y abandoné, como en una frontera, la otra parte de mi propia vida. No sé qué me espera [...] lo que sea será” (205). Lo que sucede es que en la fiesta se reencuentra con Osvaldo: "por fin estuve en lugar correcto y a la hora indicada" (206), e inician una relación de transferencias. 


\section{A. Anulación del ser como modalidad del ser: Nieve aprende el discurso de la unanimidad -la "transcripción pública".}

El meollo ontológico que planteamos es este: la anulación del ser es una modalidad del ser, en cuanto a que las fuerzas externas e internas que imposibilitan al ser, catapultan la proyección del ser fuera de la realidad impuesta. Entonces el ser Nieve se expresa ya sea en el Diario (que es la "transcripción privada" asediada, en conflicto, insertada dentro del ojo del panopticón), ya sea en la poética de la ciudad diezmada ciudad que se derrumba y se reafirma en una ensambladura de resistencia, análoga a que Nieve articula en su Diario — para sobrevivir. Diezmada por todos lo que se fueron - y los que se quedaron.

Para enfrentar la nueva vida con Osvaldo, tendrá que aprender el juego de las apariencias, amoldarse, entrar por el aro de la "transcripción publica". Las referencias a su ser Nieve atrapado, del que disponen los otros, se reiteran durante esta etapa: "Yo, una pequeña perla ahogada por su ostra" (212). Como requisito para la nueva vida de privilegios, la narradora reconoce que ha de representar otra según la voluntad de Osvaldo:

Esta no es seguramente la misma isla que yo cada día remonto sin desayunar hasta la escuela, al otro lado de la ciudad. Él hablaba de otra Cuba, de otra Habana y de otra Nieve, la que se fabricó cuando me vio, sin admitirlo, frente a la galería la tarde del desplome del edificio. Me busca como quien busca una cartulina en blanco y comenzó a dibujar mi boceto. (209) 
Se reconoce entre las mujeres, en los óleos de la "nave de mujeres" de Osvaldo, como si él la hubiera previsto: "Una de ellas me recordaba a mi cuerpo; desde el dibujo, escondía su mirada detrás de las gafas negras. Está húmeda, como yo; pronto se secará para venderse en no sé cuánto (207). La narradora traza intuitivamente la simetría poética: El vocablo "venderse” que adjudica al cuadro, se presenta análogo al canje al que se presta la narradora. Parece decir: si me callo, me someto e instruyo en el juego de las apariencias, entonces podré tomar "leche pura, cremosa" (208), comer, vivir cómodamente "presa" y huir de Cuba en un futuro (Osvaldo tiene posibilidades de viajar fuera de Cuba). Se ha visto cómo la protagonista a través de su corta vida, se ha visto frecuentemente obligada, por allegados y por la circunstancia social, a anular su verdadero ser fuera del Diario, en pos de representar lo que se espera de ella, lo conveniente.

Nieve se anula. Prueba de ello es que queda alterada la cronología del registro. A partir de que Osvaldo le prohíba escribir en el Diario, ella no dejará de escribir pero se le hará más difícil. Las entradas dejan de estar fechadas todo el tiempo, apareciendo a veces tituladas, o simplemente indicando la estación y el año en que fueron escritas, respondiendo al rigor impuesto: “Si quiero sentirme en el 'mundo' debo permanecer en este círculo y no decepcionarme, mucho menos flaquear"-se auto instruye Nieve. Asimismo aprende que mostrar sus verdaderos sentimientos es señal de flaqueza, y no está dispuesta a perder una vida de prerrogativas mostrándose inepta. En este punto, recurrentemente se refiere a sí misma de modo peyorativo, juzgándose a través de los ojos de los demás como "una guajirita estúpida e incoherente” (230). 
Tal vez sienta que sincerándose en el Diario expía parte de la culpa que experimenta al formar parte de una farsa. Conciente de las contracciones anota:

Tengo claro que el Diario está prohibido en esta relación, pero desahogarme en él es mi única posibilidad. Siempre ha sido así, hasta en los peores tiempos. Llevo casi cuatro meses escribiendo muy poco. No quiero poner fechas, tampoco días, aquí toda la semana se convierte en una misma aventura. (229)

En un tono más maduro, reflexiona sobre su circunstancia: “Allá afuera existe otro país que una muchacha como yo no puede ignorar" (230). Pero aprende que si no se deja educar será excluida: “Opiné en las conversaciones donde no debí opinar. Parece que me quiere (Osvaldo) callada, observando mientras me entero de que se trata todo aquello" (219). Se trata de una representación: “[...] este es el precio que tengo que pagar para ser aceptada" (230) — apunta.

Dado que el Diario articula precisamente el bildungsroman de Nieve, en la progresión de los apuntes va acumulándose una especie catálogo de instrucciones de cómo someter al ser. Deliberadamente postergándolo a cambio de prebendas. Cuando por momentos se siente aceptada en el universo de Osvaldo anota complacida: "Parece que superé el examen" (231). A través del Diario-novela de aprendizaje observamos la progresiva domesticación de su carácter; Nieve aprende — torpemente quizás—a desenvolverse dentro de la "transcripción pública" que alcanza la intimidad compartida con el amante.

Mientras haya representación en el ámbito privado que comparte con Osvaldo, la intimidad participa en la "transcripción pública". De modo que la "transcripción privada" 
se reduce aún más, circunscribiéndose solamente al Diario. Atrapada así, el discurso de Nieve se dosifica y tonifica, gana en matices. De la niña en Cienfuegos a la adolescente en La Habana, el tono se enriquece, paradójicamente en la necesidad de reducirse a la mínima humanidad del ser Nieve. La joven se permite incluso cierta ironía sutil tonificando el relato de los hechos. Veámoslo en tres puntos.

Primero, observamos que durante este periodo de recogimiento en casa de Osvaldo, Nieve no confronta al poder directamente ni indirectamente, sino que lo evade, y al hacerlo se pliega sobre sí misma. Refugiándose en el Diario, crea un doblez de sí, en el texto. Es este un mecanismo psíquico de supervivencia, común en sociedades totalitarias, que no deja de ser agotador para el lector avisado, resultando cargoso en su retórica, discursivamente engorrado, perceptiblemente indirecto - aunque en nuestro estudio hayamos escogido otro enfoque. Y es que el de Nieve/WG es un discurso controlado. Los cánones del poder absolutista trazan el límite de este discurso, desde ahí el ser Nieve ha de mantenerse a flote casi inadvertidamente -para sobrevivir.

Segundo, como se ha visto, aún podrá hablarse de un discursar disidente dosificado, en cuanto a que la narradora hallará intersticios expresivos donde tanteará lo ambiguo, disfrazará el enunciado para quejarse o disputar los designios del absolutismo. El discurso se moldea a su circunstancia para hacerse posible.

Dice Fuentes:

Confrontar el patriarcado - el de Fidel Castro o el de cualquier elegido - y sus diversos sistemas de exclusión y de autoritarismo es, sin duda la postura más irreverente, controversial y radical que pueda tomar mujer $\mathrm{u}$ hombre alguno ante los poderes establecidos. (66) 
Nieve imprime en el texto la huella del miedo, el sometimiento, la necesidad de la contestación oculta, de "huir" hacia adentro del dominio que se ejerce sobre ella. Lo que nos lleva a un tercer punto.

Tercero, Nieve confronta el poder presentándose frecuentemente como neófita, ofreciendo el bildungsroman de niña/ adolescente/joven que se estrena en el oficio de sobrevivir dentro del sistema (mientras escapar no sea viable), de la mano débil de su madre primero, y de la mano controladora de Osvaldo después.

Permitámonos remontar el recorrido una vez más. Ya establecida con la madre en un pequeño apartamento en La Habana, estudiando en la Escuela Nacional de Arte (ENA), la joven se había encausado. Iniciándose la domesticación gradual de Nieve, aprendió a refrenar sus fueros y a seguir consejo: "Mi madre me llama para que no me meta a exponer arte político. Me pide tranquilidad [...] me da la impresión de que se puede armar algo gordo cuando entro a cualquier exhibición [...] el ambiente está cargado" (233). La aprendiz simulará seguirle el juego al orden social establecido, desanimada dejará de dibujar: "no pinto desde hace tiempo, casi dos años, pero ella no lo sabe” (233). No se aferrará a afectos que puedan arrancárseles, para bandear las sucesivas pérdidas: "Quizás me doy cuenta por el propio ejercicio de decir adiós en que he sido entrenada" (233). Contendrá el discurso: "Tampoco deseo contar mis planes al pie de la letra" (241). Comprobamos que durante esta etapa de estudiante en la ENA, Nieve primero está constreñida dentro el círculo de la madre y sus amigos intelectuales bohemios. Después traslada todos estos modos a la nueva vida con Osvaldo. No obstante, hará espacio para la "trascripción privada" en el Diario. 
Al estrenar pareja enseguida se supeditará a la voluntad de Osvaldo, pintor privilegiado, cotizado en Europa, que puede viajar fuera del país. A tal punto se somete a la voluntad del amante, que la narradora lega una confesión patética: "Yo, como no existo, no hablo. Cuando empiezo a opinar Osvaldo me abre los ojos" (221). También con Osvaldo (otra figura patriarcal que la educa en comportarse según las conveniencias), habrá de privarse. Bajo estas condiciones que la derogan, Nieve formula otra modalidad del ser Nieve.

Es así como continúa creando a través de la escritura del Diario, su propio espacio sitiado. La transcripción una vez más se ve amenazada; los distintos estratos de su vida, privado y público, continúan dominados por el poder patriarcal:

Ahora Osvaldo, como mi padre, me prohíbe el Diario [...] No sé por qué mi padre y Osvaldo odian el Diario. La historia se repite en ciclos que regresan para recordarme que nunca he sido mi propia dueña [...] Apenas apunto rápido lo que vivo. De cualquier modo todo me ocurre de prisa, la premura no le cierra el paso a la reflexión de los eventos [...] no hay tiempo para narrarlo porque la censura aparece siempre con cada hombre que me cruzo en el camino. (224)

Cada figura patriarcal la amordaza, imponiéndole su decreto, su dogma. Cualquier discurso divergente ha se ser apagado; ni en público ni en privado hay lugar para la voz propia de Nieve, mientras $\mathrm{LAVOZ}^{124}$ — pidamos prestados el término y la ironía— del

\footnotetext{
${ }^{124}$ Alfredo Triff, en Hígado al ensayo. 60 recetas biliares (2010), utiliza reticentemente la distinción que tomamos prestada aquí, y que utilizaremos en lo sucesivo. LAVOZ, según Triff, es el discurso hegemónico desde la tribuna revolucionaria, que ha dominado Cuba desde 1959 a 2006, cuando Fidel Castro fuera depuesto de su cargo debido a problemas de salud. Véase específicamente el ensayo "Yemayá elabora definiciones desde el más allá” (74-75).
} 
máximo líder se alza en la Plaza, delante del monumento fálico (nos referimos a la Plaza Cívica y Monumento a José Martí, donde se emiten los discursos). Es LA VOZ que inunda los altoparlantes regados por toda la ciudad, los televisores y las estaciones de radio. LA VOZ hegemónica irrebatible que habla por todos.

Después de la partida supuestamente temporal de Osvaldo, Nieve se queda viviendo en la mansión de éste; pero ahí también se siente desplazada: "No encuentro sitio donde las cosas se parezcan a mí. A lo que deseo ser y sentir” (230). La mansión dista mucho de la "realidad" afuera. Tiene despensa de comida, aire acondicionado y lujos inalcanzables para el ciudadano común. Nieve por primera vez en su corta vida experimenta estos privilegios. Casi nunca sale fuera de la casa para no confrontar la realidad exterior a la que teme; evita en lo posible la mugre de su otrora barrio.

Recogida en casa de Osvaldo evade el devenir histórico: "Cada mañana llama mi madre para contarme qué gobierno de Europa del Este se vino abajo" (241). Evita de la casa, y participar de la maquinaria social falocéntrica con adornos socialistas. La sospecha le ha sido inoculada vía testosterónica. Desconfía de todos, concentrándose en los planes secretos de su partida: "Tampoco deseo contar mis planes al pie de la letra. Se necesita mucho silencio y discreción para salir de Cuba en este momento" (241). No ha logrado adaptarse a la vida bajo el panopticón: "Los artistas estamos en el punto de mira. Hay más policías que críticos entre nosotros" (241).

Se refugia una vez más en el Diario, mientras añora la huída que paradójicamente solo puede llegar de la mano de la figura patriarcal que encarna el amante ido: "Espero que Osvaldo pueda sacarme muy pronto. Los afectos duran en mí un tiempo limitado, si no se alimentan los pierdo. No confío en nadie. No espero nada de nadie. Así me 
educaron y así soy" (235). Nieve llega a graduarse con la obra de la quema de libros, pero debido a sus negligencias estudiantiles no será aceptada en el Instituto Superior de Arte (ISA). Siente que "todo llegó al límite. Fin de la escuela, fin de la casa en los suburbios, fin del lenguaje en clave" (246). Al cumplir la mayoría de edad, Nieve ve más cerca la posibilidad de irse: “Ayer cumplí 18 años y hoy espero mi 'carta de libertad' [...] En un mes estarán los papeles resueltos y Osvaldo vendrá a buscarme". Llegando incluso a despedirse de su madre: "En Cuba ya no tengo nada que buscar" (245).

Pero la espera se alarga y pasarán seis meses antes de vuelva a escribir en el Diario. Nieve ve enfriarse su relación debido a la distancia: "Cada vez menos llamadas, menos su voz en mi cuerpo" (247). Por lo que regresa al Diario. La supervivencia del ser Nieve se impone ante la precaria realidad. La necesidad de irse, escapar, va de la mano de la necesidad de adueñarse de su propia voz. Desde la intimidad del Diario, retoma su discurso disidente, enfrentándose tácitamente a LA VOZ: “Al menos regreso aquí y anoto lo que ocurre. He dicho adiós tantas veces y para nada, aquí sigo anclada al fondo" (248).

Dice Fuentes: "El feminismo plantea que la tradicional exclusión de la mujer de las esferas donde se planifica y conceptualiza el rumbo de una sociedad es la razón fundamental de que se perpetúen las dictaduras" (76). Si se acepta esta premisa, resultará más fácil entrever el elemento disidente en la imagen arquetipo de sí misma ofrece la autora, en la estampa virginal perversa que encabeza el Diario-novela, y que analizamos al principio de este capítulo. Revisémosla: Nieve se vale de un Diario en una mano y un carmín en la otra, en tanto que Nieve en su Diario contiene su voz, su "transcripción privada" en conflicto, y el carmín es el símbolo de su feminidad empuñado como señal de 
identidad femenina. Ambos elementos son símbolos de su verdad "desnuda" en la imagen: Nieve idealiza una imagen redentora de sí, por medio del desnudo y el discurso (por accidentado que este sea), afincándolo en la afirmación de los atributos de su sexo.

El Diario y el carmín de Nieve/WG son la contrapartida del fusil, del uniforme verde olivo, la barba, el tabaco y demás atributos masculinos en el poder. El Diarionovela es la contrapartida de la retórica de LA VOZ inapelable que retumba en los altavoces, en los televisores y en la radio, las consignas cuajadas de aberraciones sexistas, caudillistas e intolerantes que repican en la "transcripción pública".

\section{Submodalidad ser Nieve y ser Diario. ¿Cómo hablar de espacio ontológico en un espacio sitiado?}

El panopticón de Jeremy Bentham, que presentamos en el Capítulo I de nuestra tesis, nos sirve de modelo para comprender el espacio vigilado de la Cuba en que vive la protagonista de WG -y la propia autora (vigente aún hoy, casi tres décadas después del derrumbe del muro de Berlín). Hemos demostrado cómo el poder alcanza hasta la "transcripción privada" de Nieve, coartándola. Constatemos ahora que Nieve vive en un espacio constantemente vigilado, asediado. Desde pequeña, debido a que la madre estuviera casada con un extranjero, Nieve se ve enfrentada a la vigilancia del Estado: "Me paso a la cama de Fausto, él me explica que es una cámara, que son los reflejos de alguien que nos chequea desde lejos [...] y me meto debajo de la colcha para esconderme del ojo que nos mira" (21).

Pidamos entonces prestado el concepto de "lugar" de la cárcel modelo de Bentham, en cuanto a que este espacio vigilado implica la destrucción de "lugar", mientras todo lugar es un lugar vigilado, localizado, instrumentalizado (donde no hay 
nada orgánico), donde se desmantela la posición orgánica en el espacio: este es el "sitio" ${ }^{25}$. Luego "sitio" aquí cumple con la homogeneidad, planiformidad, serialidad para un comportamiento del individuo que se disuelva en la colectividad autómata; es deshacer el lugar, desmantelarlo en pos de una homogeneidad forzada.

Precisamente, La Habana de Nieve/WG, es una ciudad "sitiada". Donde el individuo ha de cuidarse de lo que habla para que no le lean los labios, donde los vigilantes de la Seguridad del Estado apostados en todas partes, los Comités de Defensa de la Revolución y demás ramas gubernamentales, fungen como vigilantes del comportamiento del individuo: "Hay que hablar muy bajito porque sospechan de todo. Los planes de irnos. Los planes de permutar la casa para La Habana antes de que nos den permiso de salir" (104). Este es el lugar sitiado, el sitio constantemente observado, vigilado. Geográficamente también cercado por el agua: "Esta ciudad está sitiada por el mar" (153). Y desde el prólogo Nieve/WG ${ }^{126}$ anuncia: "Afuera me siento en peligro, adentro me siento confortablemente presa" (10).

Precisamente, si regresamos al estudio de Scott, vemos cómo establece una analogía entre el individuo en una sociedad totalitaria y un presidiario que está sujeto al dominio de la institución y sus carceleros, donde frecuentemente se da una tiranía brutal y explotadora infligida por los guardias. Incluso el preso deba medir sus palabras delante de otro preso al que se siente subordinado, más que delante de los guardias. Recordemos

\footnotetext{
${ }^{125}$ Véase el Capítulo I de esta tesis, donde se explica el uso de "sitio" para el lugar vigilado del panopticón, donde "sitio" es homogeneidad, planiformidad, serialidad, es deshacer el lugar, desmantelarlo. De este modo la palabra "sitio" es aquel lugar asediado, La Habana de Nieve/WG es ejemplo de ello.

${ }^{126}$ Hemos de suponer que la voz narrativa del prólogo es la autora que ha logrado viajar varias veces fuera de Cuba. De ahí que pueda valorar su estado comparativamente. Notemos que la observación contradice el deseo de viajar truncado al que se enfrenta la protagonista adolescente.
} 
cómo Nieve "aprende" a comportarse dentro de este régimen, en la escuela de arte, en su relación con Osvaldo, con la amiga Cleo, etc. Lo curioso en estos casos, y psicoanalíticamente factual, es que sincerarse con alguien bajo este régimen establece de manera inmediata una relación de poderes asimétricos. Este fenómeno es lo Scott llama “dominación dentro de otra dominación" (26), que no es más que una negociación de poderes opresivos bajo un sistema que oprime.

Sabemos que las estructuras de poder totalitarias funcionan de manera opresiva, minando de miedo al ser humano, despojándolos poco a poco de su dignidad, y de los más mínimos rasgos de civilidad: "Mi madre ha regresado de la guerra de Angola. Trae la piel muy amarilla, anda con temblores y dice que van a venir por ella en cualquier momento. Tiene más miedo que antes” (22). Las imposiciones, las amenazas, los chantajes, las delaciones, crean una presión sobre el individuo que va moldeado esa actitud des-individualizada, domesticada, de servidumbre — lo que Foucault analiza como la dinámica entre disciplina y castigo. El automatismo del individuo fungiendo dentro de la desidia robotizada de las masas se constata en Nieve, cuando está en el Concentrado Militar: "Marcho, grito consignas, saludo con la mano [...] Órdenes, órdenes, órdenes" (160). O cuando acude a los funestos "actos de repudio" contra los

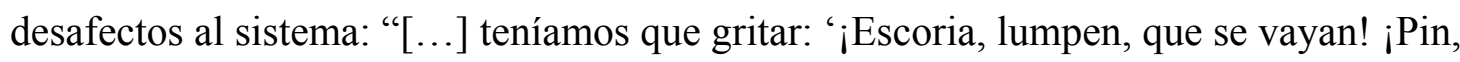
pon, fuera, abajo la gusanera!" (126). Colectivo humano donde llegan a intercambiarse el papel del opresor y el oprimido, con tal de asegurar la supervivencia, dando lugar a la "hegemonía ideológica" que según Scott conlleva este fenómeno:

La hegemonía ideológica en casos de subordinación involuntaria, creo yo, puede ocurrir sólo si dos condiciones astringentes están dadas la primera 
es que existe una gran posibilidad de que un gran grupo de subordinados eventualmente venga a ocupar una posición de poder. La expectativa de que uno eventualmente pueda ejercer el dominio que uno soporta hoy es un incentivo que ayuda a legitimar estos patrones de dominio. (82)

¿Ecos de Michel Foucault? Scott señala el adjetivo involuntaria porque aunque el individuo está conciente del intercambio de poderes, está supeditado al poder, atrapado en el paradigma del sistema opresivo al que contribuye como víctima. Visto así no queda espacio a la disidencia, ni al criterio alternativo, la hegemonía del poder totalitario no admite hendiduras -al menos esa es su meta. La madre, Leandro (el amigo protector de ambas) y Nieve evitarán asistir a "La marcha del pueblo combatiente", encerrándose en el modesto apartamento hasta que todo hubiera pasado:

Cerramos la única puerta y la única ventana del apartamento [...] Tocaron muchas veces muchas veces a la puerta desde las seis de la mañana, pero no abrimos. Piensan que vamos a ir por la escuela o por el trabajo, por eso no se puede hacer ruido. Los viejos que no van al desfile pueden descubrirnos. (128)

Dentro de este panorama ineluctable Nieve escribe en su Diario. Lo que representa una necesidad del ser Nieve, de revertir el designio, revocar este espacio sitiado, aunque solo sea desde la forma artística, apostándole al secretismo del medio expresivo: "Cuando todo el mundo regresó del desfile abrimos la ventana” (128) — apunta.

Porque de igual manera que existe un ser Nieve, existe un ser Diario. El ser Diario es una dualidad inestable: están el diario para Nieve y el diario en sí mismo. El ser 
Diario tiene una especie de incrustación del ser Nieve: es él y es el ser Nieve. Solo que ser Nieve es un aspecto de ser Diario — la posibilidad de ser Nieve está dada en la medida en que ser Diario le contiene.

Hemos probado que el Diario para Nieve es la "transcripción privada" sitiada, que facilita ser Nieve, el "claro en el bosque" — la verdad del ser y del arte según Heidegger que analizaremos en detalle más adelante— pero es más que eso. Además es el "tú" dialógico (el otro), y en última instancia es la hechura de WG, el artilugio del ser Nieve, la factura final del Diario que nos presenta la autora.

Para entender el diario en sí, independientemente de ser Nieve, hemos de apoyarnos en la tesis de Anna Jackson ${ }^{127}$, que desde un análisis formal del género, se encarga de desgranarnos los efectos estilísticos que contribuyen a una "poética del diario", tales como la yuxtaposición de detalles, lo dialógico — la falsa apariencia de un destinatario, "la representación del 'yo"”, lo confesional, la forma periódica, la fragmentación, la interjección del flashback, lo "informal", e incluso el elemento performativo como marcas estilísticas de esta escritura, así como las paradojas que se desprenden de estas particularidades (6). Parte de lo que llamamos el diario en sí, es lo Jackson analiza como aspectos del género, a saber: el "arte verbal", la construcción de una narrativa, el estilo y el tono que atraviesan la obra —que hemos anotado anteriormente, bachelardeanamente, como manifestaciones de la "intencionalidad" del ser.

\footnotetext{
${ }^{127}$ Jackson analiza seis diarios, examinando las muchas formas que toma el diario como género: confesional, dialógico (el yo y el tú), la "informalidad" considerada una "forma artística, la "verosimilitud" o el testimonio acotados, la crónica, la forma periodística, etc.

Una forma más reciente del género en el medio digital es el blog personal.
} 
Pero su análisis no abarca todo lo que distinguimos como ser Diario; hay aspectos de este diario en particular —el de Nieve- que expresan la cualidad subterránea, oscura del diario en sí, lo particular, lo único, lo irreducible que le pertenece: es el objeto (los cuadernos), es la expresión pura (sin pretensiones literarias), y todas las posibilidades que tiene. Pongamos que las características más notables del ser Diario aquí, están dadas en la necesidad de expresión: El aspecto de la Nieve/WG que escribe por la necesidad de expresarse —no necesariamente porque quiera hacer arte/literatura. Un presidiario (valga la afilada etimología), no está necesariamente haciendo nada artístico cuando escribe sobre su día día en la pared de su celda — es pura expresión, proyección. Y este elemento de ser Diario completa la imagen que tiene el lector del originario. Dice Jackson: "Cada versión del 'yo' en el diario es a la vez referencial y construida, de igual manera que la escritura autobiográfica es a un tiempo referencial y construcción” (157).

No se trata aquí de determinar si TSV es un texto híbrido, ficción o testimonio autobiográfico, o ambos. Nuestro estudio ubica la proyección del ser en el centro mismo de la obra de arte: ser Nieve dentro de ser Diario. Comprendérsele como artísticamente construido desde el Diario-novela de Nieve Guerra, propiciado por el ser Diario, privado de manifestarse en libertad — poéticamente oscilando entre la trama social y la íntima, al cobijo del papel donde se coagula una intimidad sitiada.

Dice Nieve:

Toda esa carga la lleva mi cabeza y si le vierto en el Diario es para aliviarme, para intentar postergar lo que no comprendo. Por eso siempre vuelvo a él. Aunque quiera dejar de escribir al final regreso; éste es mi 
"túnel popular", mi "refugio de guerra", mi escondite secreto, mi verdadero confesor. (184)

Sin embargo es obvio que al "verdadero confesor" no se le dice todo. Saltan rotundas omisiones ${ }^{128}$ y reelaboraciones de los hechos — combinados sí, como se ha visto, con irreverencias entreveradas y denuncias enmarañadas en preguntas, desconcierto y descubrimiento púberes. Es que éste tipo de escritura está justificado en la naturaleza misma del medio, que favorece a las lagunas del texto y las yuxtaposiciones contingentes de la vida misma.

Hallamos sinécdoques, como la que encabeza el párrafo citado arriba: "esa carga la lleva mi cabeza". Sinécdoque que prefigura a una otra — la cabeza, como responsable de emociones prohibidas, castigadas por el Estado patriarcal, cuestionamientos emanados por el todo, el ser Nieve. Táctica que la exime en parte de la responsabilidad de pensar por sí misma, desafiando LA VOZ.

Precisamente Jackson nos alerta sobre el peligro de leer un diario -o una novela que apela serlo — como la representación del ser escritor ${ }^{129}$, y de cómo la escritura de un diario está conformada por las demandas, restricciones y posibilidades del género:

[...] un proceso que necesariamente contingente de eventos que están fuera del hecho de escribir. Es otra manera de penetrar lo que es el diario [...] la forma abierta del diario no permite una interpretación rígida de la

\footnotetext{
${ }^{128}$ Un ejemplo notable de omisión deliberada es el hecho de que Nieve no refiere cómo logra entrar en la escuela de arte. ¿Cómo una niña "con problemas" fue, de un Centro de Rehabilitación, a la Escuela Nacional de Arte (ENA)? ¿Fue acaso a través de los contactos de la madre, algún amigo "integrado" y miembro del Partido intervino por la niña? Las respuestas a éstas y otras preguntas que surgen a partir del la lectura, quedan omitidas del relato.

129 Véanse las páginas 4-5, 156-57. Notemos que Jackson basa su tesis en la forma y no el contenido del diario como género, apoyándose en sus cualidades formales.
} 
vida, no siquiera de la narrativa de la vida. El diario presenta un collage de interpretaciones, y una lectura del diario que responde a estos desplazamientos y contradicciones será un collage de lecturas. (68)

Precisamente TSV es la construcción del personaje Nieve, y aunque esta elaboración distancia a WG del cuestionamiento al entorno de la protagonista, colocando a la autora a cierta distancia de la "verdad" plausiblemente peligrosa plasmada en el texto, el performance final es de WG. El ser Diario propicia la expresión última —la entrega en bajo tono de la historia. Sea el ser Nieve o el "ser real" (la autora), el despliegue de/en la obra de arte es siempre ontológico. Siendo la expresión artística el alivio y el vehículo del ser Nieve, su ventilación ${ }^{130}$. La cualidad dialógica del medio corrobora nuestra tesis, en cuanto a que los pronombres "yo" y "tú" son identificaciones que ya sugieren una distinción del ser, una conciencia de sí (Jackson 10).

Puede afirmarse entonces que el Diario de Nieve, por su naturaleza, evidencia cómo el ser Nieve (y la autora tácita) escoge (consciente o inconscientemente), el medio de ser Diario, su expresión, su lugar — fuera y dentro del panopticón en el caso de Nieve/WG. Precisamente la yuxtaposición de los hechos (como característica del género), facilitando la manipulación de la experiencia, maniobra artística que trasmite la precariedad, el estado de sitio en que escribe Nieve. Empero, el escritor de diario ejerce el control sobre lo que entrega, un contrapunto entre lo que omite, lo que puede ser leído (es el caso que nos ocupa), y la imposibilidad de comunicarlo todo —uroboros de la forma

\footnotetext{
${ }^{130}$ Nótese que damos crédito al enfoque de Jackson, que se concentra en las demandas formales del género, alejándose del peligro que ella pone en palabras de Hermione Lee: "los problemas que se derivan de tratar a los libros como personas y a las personas como libros" (17).
} 
artística: "Mi Diario es un lujo, mi medicina, lo que me mantiene en pie. Sin él no llego a los veinte años. Yo soy él, él es yo. Ambos sentimos desconfianza" (144).

\section{Submodalidad Todos se van}

El título del libro da la pista: El Diario-novela es una alegoría del abandono.

Nieve ve irse a sus amigos, sus afectos, a los amigos de su madre, a su amante, y para todos ellos fragua un ritual de despedida en el Diario. Se ha visto que el ser Nieve se ve imposibilitado de huir, escapar del ojo del panopticón como han hecho todos los que se fueron: "He pagado un precio muy alto por crecer sola mientras todos se marchaban de la isla" (9) —apunta en el prólogo.

Pero además, Nieve se siente abandonada de muchos conciudadanos que golpean, presionan, vigilan y aterrorizan, con los que no halla punto de encuentro. Un estado en falta de "solidaridad cívica", donde Nieve se siente despojada de la "nación que nos falta", según Rafael Rojas, carencia enraizada en dos aspectos que trazara Jorge Mañach: "la integridad" y "la falta de solidaridad cívica" (Rojas, El arte 90-94). La "integridad" a una soberanía frágil debido a la gran dependencia de Estados Unidos — su presencia en la economía, la política y la cultura de la isla. Dos aspectos que determinan el deteriorado tejido social cubano. Porque esta dependencia sigue siendo esencial desde la Cuba republicana hasta hoy en día, aunque ha dado un vuelco cínico: la ingerencia norteamericana de corte imperialista, dio paso a una penetración ideológica (sustentada por la proliferación de antenas prohibidas) considerada disidente por parte del gobierno (y vigilada de cerca por un sistema de escucha). La opresión por medio de la fabricación de un "enemigo" que contribuye al sostenimiento del poder; y el envío de "remesas" de familiares exiliados sobre las que se sustenta la dictadura. 
Revistemos la conversación entre Nieve y su madre en el parque, posterior al encuentro entre jóvenes artistas y el máximo líder —que ya analizamos desde otro ángulo. A partir de esta experiencia, a Nieve se le presenta el mundo como un abismo de posibilidades. Debe elegir entre quedarse, con todo lo que esto implica, o irse: "Si quieres escapar de la política tienes que escapar de Cuba" (187), le dice la madre. Atrapadas e imposibilitadas de huir como los que se fueron — todos los intentos se verán truncados— la madre le propone una utopía: "Mi madre habla de un lugar neutral, idílico e inexistente" (188). Aterrorizada la joven apunta: ¿A dónde iré en caso de quererme esconder de todo esto? ¿Qué haré con mi madre, que ya es como mi hija?” (188).

Mientras la madre anhela una utopía, Nieve elabora un espacio propio. Dicho de otro modo, Nieve se evade de la realidad sistemáticamente en su "claro en el bosque" ("Lichtung" heideggereano), que es su Diario, porque "Dasein" elude todo lo que le amenaza ${ }^{131}$ : "Vivo refugiada en el Diario y solo me comporto cómoda y normal entre sus páginas" (9). Lo que nos plantea una relación entre ansiedad y espacio ontológico. Nieve opta por evadirse de la realidad que la angustia, y escapa al Diario donde —como se ha visto- también manifestarse está cuartado. De manera que este "claro", que para Heidegger es el lugar donde se revela la verdad del ser, que ilumina, Nieve lo halla en el

\footnotetext{
${ }^{131}$ Nos apoyamos en la noción "Dasein" de Heidegger, en El ser y el tiempo. En la descripción del ser ser, en vez de usar la palabra ser, Heidegger utiliza "Desein" (Das- es el espacio que se abre, e ilumina, estar$a h i$ ), paro evita el uso fenomenológico que se da al vocablo ser. Heidegger quiere ir a un análisis ontológico; o sea, el ser en tanto que es -y se hace de otros tipos de herramientas para abordar el fenómeno, porque el ser fenomenológico oculta algo, que es "Dasein" —otra complejidad, según el filosofo. "Dasein" significa: el ser, las notas fundamentales de ser: 1. Su existencialidad — que es el ser ("Dasein") constatado en el mundo, estar-en-el-mundo, y su devenir (al futuro), su utilidad ("Zeus") y la "Cura" ("Sorge") de la existencia que es la actividad diaria de cualquier persona. 2. Su factualidad ("Faktizitat"), es estar-en-elmundo y reconocerse en la situación inevitable, estar arrojado en la vida ante designios que no se han escogido. 3. La caída ("Verfallen"), es estar-con-los-otros, no tiene connotación moral, es la huida del ser, la mala fe, la autoenajenación - "Dasein" se pierde en los otros - que Heidegger llama "habladurías".
} 
Diario. Lo que decimos es que en "claro" del Diario se revela el ser Nieve, pero no exento de problemas: el "claro" está sitiado.

Sabemos que puede existir un lugar en el mundo, pero ¿existe "un lugar” en el arte? Ese aspecto que le toca la obra de arte es importante para la comprensión de "lugar" en el Heidegger tardío. Vemos el "claro del bosque" como el lugar de la verdad del arte, y es un lugar de tensión. Como el Diario de Nieve, "Lichtung" por lo general está oculto; de ahí se hace un claro.

Analizamos que en el ensayo "El origen de la obra de arte", la pregunta crucial no es el "qué" del arte, sino el "dónde" de la obra de arte. Este "dónde" en que ocurre la obra de arte, y por tanto la verdad del arte, es descrito como "un claro en el bosque". Para el ser en conflicto ("Urstreit") entre lo que se muestra y lo que se oculta, existe una abertura, es decir, "se hace lugar". Esa fisura frágil del "claro" hace posible no solo la forma de la obra de arte, sino el "dónde" en que reside la verdad. Heidegger lo explica así:

La lucha que se asienta en la tierra y queda fija es forma, "Gestalt". Es decir, la verdad queda emplazada en la forma. Ésta grieta es el ajuste del brillo de la verdad. Lo que llamamos forma (“Gestalt") siempre se debe pensar en término de su lugar (“Stellen") particular, el enmarcado en que ocurre y se establece. (Casey 267)

Del análisis anterior sale la idea de "región" ("Gegend") que el Heidegger tardío elabora como el lugar de "el claro en el bosque". Región es superada por el gerundio (“Gegnet”), regionando y (“Gegnet") “eso-que- regiona”. 
La implicación espacial ahora abarca no sólo lo material, lo físico, sino también el pensamiento mismo. Nos ayuda a comprender la relación que defendemos entre espacio y ser Nieve. De hecho, "pensar" ("Denken”), es para Heidegger, el pensamiento orientado del ser), puede considerarse una manera de "acercarnos en la distancia" (Casey 271). Desde ahora, estar en una región significa asimismo "movernos en cierta cercanía"132. Lo importante aquí es que para el Heidegger tardío, "lugar" termina siendo una escena para el encuentro, para el "cara a cara". Luego "lugar" termina siendo "eso-que-regiona".

Heidegger nos presenta una paradoja enriquecedora respecto a ser, siéndolo en relación a la distancia entre las cosas. Para el filósofo la cercanía tanto como la lejanía de las cosas nos acercan al mundo -y en está relación con el mundo constatamos el espacio. Ser una cosa, entonces, no es solamente estar cerca, por ejemplo, cerca de "Dasein" u otras cosas. Más que la mera proximidad está en juego. Lo que importa (a Heidegger) es que acerquemos lo que está alejado y remoto (Casey 273).

Nieve reacciona a las partidas batiéndose en duelo en el Diario, donde todos los que se van la acomodan en la distancia relativa del abandono. Pero la paradoja heideggereana nos reitera que "Dasein" también es una manera de regresar al mundo del que Nieve se siente excluida, ya que este espacio solo puede ser concebido en relación con el mundo (no hay manera de ser fuera de él). Visto así, los que se van están presentes en los que se quedan ${ }^{133}$.

\footnotetext{
129 Es aquí que Heidegger apunta al hecho de la tecnología, que para los años 50 ha abolido las distancias, de modo que "una corta distancia ya no significa en sí misma cercanía, ni una gran distancia algo remoto" (Casey 272). Para Heidegger, la tecnología ha abolido distancia y cercanía, ¿puede entonces sugerirse un paralelo entre "tecnología" y "sitio"?

${ }^{133}$ Esta idea ya la ensayamos cuando afirmamos que TSV contiene a Cabrera Infante, el exiliado, muy al principio de este capítulo.
} 
Según Heidegger, se trata de no "escatimar" y "preservar" las cosas. No es lo mismo que tenerlas cerca ("Dasein"), sino saberlas en el mundo: "Duelo es siempre quedarse con las cosas" (Casey 273). Visto así, quedándoselos es para Nieve una manera de residir en/con los que se van. Lo que invariablemente nos regresa a "lugar", porque las cosas residen no solamente en el mundo en que existen, sino en un lugar en particular donde se constatan — de acuerdo al filósofo ${ }^{134}$.

Heidegger habla de unos espacios interválicos que están dados como pura extensión, además del espacio "localizado". Entiéndase: el espacio es interválico, el lugar es localizado. Y es que espacio es generado por la distancia entre las cosas (Casey 275). Por ende, constatemos cómo el espacio ontológico es interválico, conecta lugares. Empero, la distancia interválica no está determinada por la distancia física entre las cosas. Ejemplo de ello es el hecho de Nieve evoque a Europa (y a París) repetidas veces en el texto, lo que hace a Europa parte de su realidad, aunque no tenga contacto físico con ella ${ }^{135}$ : "No me hace falta viajar: vivo en una Europa inventada en medio del Caribe" (229).

En un momento dado, cuando Osvaldo todavía está en Cuba, expulsan de la ENA a Alan (el amigo "conflictivo" de Nieve, integrante del Grupo Arte Calle) por motivos políticos. Y es que a veces la realidad de afuera (que ella trata de evadir), toca literalmente a la puerta de la casa. Dos entradas más tarde sabemos que Alan se va de

\footnotetext{
${ }^{134}$ Véase el análisis extenso del "ser ahí" (Heidegger, El ser 58-252)

135 Nieve se expresa así cuando vive en la mansión de Osvaldo, rodeada de comodidades. Pero también se refiere a la Europa metafísica, a la que sueñan escapar; destino que ha embargado su vida desde niña. Por ejemplo, la madre está casada con un sueco con el que madre e hija sueñan escapar a Europa. También, París aparece repetidamente en la novela como referente al que se huiría, en caso de que fuera posible.
} 
Cuba y viene a despedirse de Nieve. Alan también partirá camino del exilio. Ella apunta: "Se va de aquí la única persona que me invitaba a ser feliz con naturalidad [...] Se va México, quizá a Miami. Disolvió su grupo porque casi todos se han ido escapando poco a poco" (226). Para despedirse de Nieve, Alan salta el muro metafórico y físico que circunda la mansión, y toca en los cristales. La despedida es díscola; él la besa en la boca y ella sorprendida lo abofetea:

Ambos empezamos a llorar y golpearnos. Alan volvió a saltar el muro de regreso y me dejó sola y mojada frente a mi nueva casa. En ese instante quise morir y no tuve más remedio que venir a escondidas hasta el baño. Me sequé con toalla, y luego me puse a escribir todo lo que había pasado, sofocando duro los sollozos, poniendo sobre el papel lo que acaba de ocurrir. Adiós Alan Gutiérrez. (227)

El llanto desconsolado de Nieve en el cuarto de baño parece trascender el momento específico. Alan suma uno más a la lista de partidas que sirven de basamento al libro. Siendo las partidas el eje gravitacional de esta historia. Partidas que apuntan a una política del adios ${ }^{136}$. La partidas de otros reafirman la falta de libertad que tienen madre e hija para irse -ellas enfrentan esta imposibilidad muchas veces. Como cuando el "viejito pintor", referido simplemente como "Lam" (pero hemos de suponer que es Wilfredo Lam, 132-33), le extiende una invitación a la madre para que lo ayude en su taller de cerámicas en París, pero el gobierno no les dará el permiso de salida. Se irán también Osvaldo, los amigos de Osvaldo, Cleo (amiga de Osvaldo), Fausto (el esposo de la

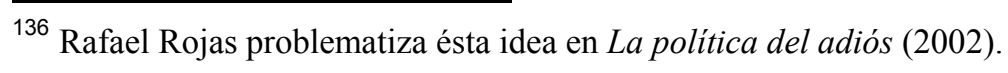


madre) y Leandro (amigo de la madre que en un momento dado atendiera a Nieve como una hija), se irá el padre de Nieve, y se irá Antonio.

Cleo es una poeta amiga y ex amante de Osvaldo, que en un principio se presenta como contrincante, pero que terminará siendo amiga de Nieve, cuando Osvaldo se ausente. Varias entradas darán cuenta de la amistad condicionada que se dará entre ambas, donde Cleo fungirá como una especie de maestra de ceremonia de iniciación, para una vida de indulto, dentro de ciertos límites dictados por la "transcripción pública" -que es el discurso de la unanimidad que sustenta LA VOZ. Precisamente, Nieve se refiere a ella con los mismos términos que otrora usara para referirse a su padre, o a Osvaldo: "me están (Osvaldo y Cleo) poniendo a prueba" (230), "parece que superé su examen” (231), etc.

Cleo también se irá al extranjero, dejándole un legado de versos y sombreros: "Dije adiós a todos mis amigos de infancia. Hoy dije adiós a Cleo" (236). Sumando al abandono que siente Nieve: "Mi libreta telefónica está llena de rayas rojas [...] Todos se van. Me dejan sola. Ya no suena el teléfono" (242). El hecho es que Nieve está obligada a quedarse en el "ejercicio de decir adiós" en el que ha sido "entrenada" (235). Pero en las pérdidas halla fuerza para resistir: "Soy fuerte porque estoy sola" (194). Los que se van y los que se quedan son dos aspectos de la misma realidad del ser Nieve.

La ciudad se va quedando atrás, porque ya no es lo que fue sin los que le habitaron. La ingerencia de lo político se impone en sus plazas, se cuela por las hendijas al universo privado: los altoparlantes dicen algo muy distinto de lo que ilustran las partidas. El miedo acalla los lamentos. 
Nan Ellin recopila una serie de ensayos en el libro The Architecture of Fear (1995) basándose en la idea de que el ser humano responde al miedo desde la razón, la creatividad y el espíritu. Lo que ella llama "urbanismo de ofensiva", presenta la arquitectura "viviendo" al individuo, en lugar de éste viviendo en medio de una arquitectura moribunda (Ellin 9). El discurso de Ellin hace contrapunto con versiones fílmicas recientes como los documentales Suite Havana (2003) de Fernando Pérez, y Arte nuevo de hacer ruinas (2006) de Florian Borchmayer. Ésta es La Habana de actualidad histórica que trasluce en TSV, una ciudad que en palabras de la autora, lleva inscrita una memoria silenciosa, similar a la que Walter Benjamín descubriera en Moscú donde se superponen las consignas y los próceres sobre el vacío, el silencio estruendoso de los que se fueron ${ }^{137}$.

\section{La indireción camino del inxilio ${ }^{138}$}

Nieve Guerra vive inxiliada en Cuba: 'Si quiero sentirme en 'el mundo' debo permanecer en este círculo y no decepcionarme, mucho menos flaquear" (227) —se autodisciplina. Porque su lugar es un sinlugar, desde la metáfora: "Fui soltando los pedazos de lugar en lugar al que me arrastraron y hoy no sé cómo armar mi mundo disperso, cernido como arena en mi territorio personal" (9).

\footnotetext{
${ }^{137}$ La disolución del individuo en la colectividad del proletariado, corre paralela a la ciudad soviética saturada de consignas, estatuas de próceres, agitada por la actividad político-ideológica colectiva. Benjamín lo contrasta con el silencio en las iglesias moscovitas vacías, como "estructura secreta" del pasado ("Moscow" 125).

${ }^{138}$ Más cercanos a la exploración del concepto de Paul Ilie en Literature and Inner Exile (1980), aún deseamos problematizar y expandir el término. Preferimos el uso del vocablo inxilio que el de insilio como han escogido otros autores.

En el uso inxiliado significa exiliado en su propia tierra.
} 
El vocablo inxilio ha sido utilizado por Madeline Cámara, para describir la condición de exiliado en su propio país que padecieron escritores como Dulce María Loynaz, Lezama Lima y María Elena Cruz Varela, por solo citar dos nombres relevantes de una larga lista ${ }^{139}$. Pero este vocablo relativamente nuevo inquieta. Permitámonos explorarlo ampliando su uso para los propósitos de esta investigación.

Por definición inxilio es exilio interno. Pero la condición de inxilio plantea un topos ontológico, mientras exilio sí lo es físico. De la manera más evidente, digamos que el individuo se exilia dentro del topos en que vive. Pero desde el prisma existencialista sartreano, podemos decir que todo ser vive inxiliado de sí, mientras un aspecto del ser esté oculto al ser. Inxiliándose, el individuo se exilia de sí mismo, se convierte en un extraño para sí. Entonces el significado se expande: ¿Cómo puede uno exiliarse de sí mismo?

Necesitamos otra vez de Heidegger para comprenderlo; "Dasein" e inxilio se cruzan. Mientras "Dasein" es ser-en-el-mundo, inxilio es un aspecto de "Cura" ("Sorge") ${ }^{140}$, de curarse del mundo — de ese ser-en heideggereano, el inxilio es estar en un lugar y no sentirme en él, no tener una proximidad con/en el espacio físico. "Dasein" se cura así del espacio físico que le crea ansiedad.

Comprobamos luego que exilio e inxilio no son opuestos, sino complementarios: No todo exiliado es un inxiliado, pero todo inxiliado es un exiliado. Por lo que en

\footnotetext{
${ }^{139}$ En Four Women Writers: Imagining a Matria (2008), Cámara utiliza el término inxilio para explicar la situación de la poeta María Elena Cruz Varela. Dice Cámara refiriéndose a Cruz Varela: "vive y escribe en total marginalidad artística y social" (87) (Véase el Capítulo 3).

${ }^{140}$ Para Heidegger "Cura" ("Sorge") unifica las tres maneras de comportarse de "Dasein”, a saber: existencialidad (futuro), factualidad (pasado), y caída (presente). Para más información véase El ser y el tiempo, páginas 53, 76, 153, 185-88.

Para comprender la dinámica de "Cura" véanse las páginas 298, 344 a 351.
} 
segunda instancia, vemos que el inxilio es una condición más básica que el exilio. El inxilio no puede resolverse en el exilio: si antes de irse ya no estaba allí — de modo que sartreanamente, ser es no ser. Entonces el inxilio es una categoría básica del ser.

Explorémosle su semántica poéticamente: inxiliarse es un modo de quedarse, de extrañarse del lugar que se ocupa, es exilio interior, habitar una palabra desde dentro, es una condición de desamparo en el propio terruño, es una respuesta a la circunstancia, puede ser una condición psicológica, etc.

El inxilio del ser Nieve/WG es un drama existencial (ya que todo inxilio es categoría básica del ser), pero es un inxilio catapultado por las circunstancias específicas. ¿En qué sentido las circunstancias la precipitan a ello? La razones dilucidadas aquí, pueden resumirse en tres elementos de la particularidad del inxilio de Nieve Guerra: 1. La “transcripción pública" sofoca la "transcripción privada"; la "transcripción privada" está sitiada. 2. Porque además está enfrentada al Estado patriarcal/falocéntrico que excluye al ser Nieve: "Siempre escondo el Diario de los hombres" (256). 3. Los que se van al exilio se quedan en el "Dasein" de Nieve — proximidad por evocación.

Cuando se hace "el claro del bosque" por un momento encuentra la verdad del ser -inatrapable por demás. Solo inxiliada podrá hallar éste claro, propiciarlo, preservarlo. Podrá estar presa pero halló ese momento, este espacio imprescindible de/para sí. Vemos que Nieve parece seguir el consejo bipartito de la madre: escoger entre no involucrarse en la política, o irse de Cuba. Pero lo hace optando por una indirección ${ }^{141}$-lo directo sería irse. Una manera de escapar de Cuba es evitar en la medida de lo posible la realidad, para

\footnotetext{
${ }^{141}$ Para examinar la "indirección” heideggereana consúltese el Capítulo 11, de Casey, páginas 243-84.
} 
inxiliarse ${ }^{142}$; ser Nieve solo puede ocurrir en el Diario: "Es como si se me estuviera acabando el país" (246) —dice, mientras se escurre dentro.

Nieve apenas sale de la casa que se ha quedado custodiando, "la caja de cristal" (252) que compartiera con Osvaldo (éste nunca regresará de Europa, asilándose en Paris): "Casi nunca salgo de la casa, no visito a nadie porque la mayoría de mis amigos se han ido" (241). En un ardid poético se refugia en la ciudad desolada como abstracción: "Siempre voy sola, vestida de negro por la ciudad" (232). Como si la ciudad estuviera en otro lado, y fuera ajena a sus habitantes y su devenir histórico, un cadáver de ciudad que apenas transita vestida de luto. El sistema impuesto rompe con la "lectura" intuitiva del espacio urbano (Violich 133); el sentido de lugar y/o pertenencia, es reemplazado por desarraigo in situ.

El inxilio que planteamos es también un producto de la imaginación creadora. Es un espacio dentro del escenario de la vigilancia, una zona sagrada para sí. Antonio José Ponte, en su análisis de cómo se desarrollaron los sucesos del cortometraje Monte Rouge (2005) aporta un razonamiento que también rescata el gesto de WG/Nieve. Dice así Ponte sobre el aspecto crítico al sistema de vigilancia, presente en el filme:

Aunque se tratara evidentemente, de derechos cuartados. Porque la imaginación creadora gozaba de plenos poderes sobre casi toda la realidad, no sobre la realidad toda. Fuera de esta cartografía, como tierras en las que el humor y la imaginación harían bien en no adentrarse, quedaban ciertas zonas sagradas. (Ponte, Villa Marista 43)

\footnotetext{
${ }^{142}$ Término "inxilio" no aparece en el diccionario de La Real Academia Española de la Lengua. Se lo adjudicamos a Madeline Cámara, aunque ha sido utilizado por otros.
} 
¿Y cuáles son esas zonas sagradas de la Revolución que no pueden tocarse? Según refiere Ponte "la Revolución, Martí, Fidel" (43). Visto así, la zona sagrada de Nieve es el inxilio de las zonas sagradas del sistema políticamente decrépito. En última instancia, parafraseando a Cámara, el inxilio de Nieve/WG no requiere un territorio para existir, sino lectores ${ }^{143}$.

Permitámonos establecer el siguiente paralelo entre dos indirecciones que ilustren el uso del término. El Heidegger temprano rechazaba el papel del cuerpo (así como de la conciencia del ser) en la ubicación espacial. Pero el Heidegger tardío llega a través de una “indirección” a explicarse la ubicación del cuerpo en relación al mundo, como factura de "lugar". Dice Heidegger que la angustia saca al "ser ahí" de su absorción en el mundo: "Queda quebrantada hasta las entrañas la cotidiana familiaridad. El 'ser ahí' es singularizado, pero como 'ser en el mundo'. El 'ser en' pasa al modo existenciario del 'no en su casa' (El ser 209). El paralelo que trazamos consiste en que Nieve llega a irse de la realidad refugiándose en su Diario. Paulatinamente renuncia a participar en la realidad que la angustia, inxiliándose — lo que es una indirección de las direcciones (opciones) recomendadas por la madre: irse, o quedarse (callada). Habiéndose ido de su hogar "inhabitable" en Cayo Hueso, Jovellar y Espada, Centro Habana (TSV 221), se inxilia en la mansión de Osvaldo en Nuevo Vedado, especie de burbuja ficticia — porque no le pertenece, a modo de distanciarse de todo lo que le causa ansiedad afuera.

\footnotetext{
${ }^{143}$ En Four Women Writers: Imagining a Matria (2008), Madeline Cámara concentra su trabajo en Ofelia Rodríguez Acosta, Lydia Cabrera, María Elena Cruz Varela y Zoé Valdés. Así dice Cámara: "Me he reapropiado la nación de las palabras que ellas me han dado, una nación que no requiere de territorio para existir, solo de lectores" (6).
} 
Ante la imposibilidad de expresarse libremente, madre e hija (roles que Nieve reconoce intercambiables), añoran un lugar inexistente, una utopía, viviendo dentro de una distopía ${ }^{144}$. La madre de Nieve parece escurrirse en una distracción evasiva de la realidad: “ [...] cada día está más distraída. Los carros le rozan el vestido y ella va oronda y levitando. ¿A dónde iré en caso de querer esconderme de la realidad? ¿Qué haré con mi madre, que ya es como mi hija?" (188). La actitud de la madre enfrenta a Nieve con la paradoja del inxilio.

Constatémoslo en la entrada que data el 28 de marzo de 1987, confesión que confiere un grado de desolación tal, donde madre e hija se muestran desfasadas, desprendidas una de la otra, desubicadas, huérfanas:

Mi madre rechaza lo que ama. No me había dado cuenta de eso. La Revolución siempre ha sido su vida y desde que tengo uso de razón está tratando de irse. ¿Pero a dónde y por qué? Yo sólo quiero escapar de la política, no soporto verme metida en todo esto. Algo me dice que no se pelear en esta ligas. [...] Habla de un lugar neutral, idílico e inexistente.

Cita a Cummings de memoria:

Algún lugar en el que nunca estuve, gustosamente más

\footnotetext{
${ }^{144}$ El vocablo, que no aparece aceptado por La Real Academia Española de la Lengua, curiosamente ha sido usado por escritores que reflexionan sobre las sociedades post socialistas de Europa del Este. El término distopia en español, puede entenderse como lo contrario a utopía (término acuñado por Tomás Moro, en su libro con el mismo título). El cine de Hollywood posterior a la Guerra Fría, ha recreado distopias donde un héroe lucha por sobrevivir. De modo que una distopia es una sociedad perversa, generalmente ubicada en el futuro, y contraria a la sociedad ideal. Distopia se da donde la manipulación y el adoctrinamiento masivos a cargo de regímenes autoritarios y totalitarios, llevan al control absoluto, y al condicionamiento o exterminio de sus miembros, así como la supresión de la individualidad. En el Oxford American Dictionary (2011), dystopia aparece como "un lugar o estado en el cual todo es desagradable o malo, típico del totalitarismo o de la degradación del medio ambiente".
} 
allá de cualquier experiencia, tus ojos tiene su silencio:

en tu gesto más leve hay cosas que me contienen,

y que no puedo tocar de tan cerca que me

encuentro.

Y aunque me cierre como una mano

tu mirada fugaz [...]. (188)

Nieve Guerra, antiheroína de la distopía ${ }^{145}$, al igual que su madre, se refugia en abstracciones poéticas, algún lugar en el que nunca estuve. Imposibilitadas de irse, crea un intersticio entre el irse o quedarse: añorando un lugar utópico donde no tenga que tomar decisiones políticas, mientras — le advierte la madre — vive en una sociedad donde "todo es político". Fabrica así una burbuja aséptica. Puede decirse que la protagonista escoge su lugar fuera del sitio (sitiado), halla la hendija gravitacional del ser Nieve.

Anne Troutman, en su inquietante análisis de la relación entre espacio/arquitectura y miedo, explica que un mundo paralelo habita los bordes de nuestro mundo consciente, lugares tranquilos donde soñar y descansar, lugares oscuros donde escondernos y de donde escaparnos. Troutman, sugiere con metáforas que van del espacio físico al espacio consciente, que estos espacios de alguna manera convoyan el "atrás", "entre" y "a través" de los espacios físicos, siendo son los intersticios de "las habitaciones" de nuestras vidas (145). Básicamente nos dice que la casa que moramos o hemos habitado - es la casa extendida de nuestras fronteras conscientes:

\footnotetext{
${ }^{145}$ Nieve es la antiheroína de la distopia porque no actúa contra el orden social establecido -presentándose como la víctima. Insistamos en el término distopia: Vemos así que la heroína distópica está dentro de la distopia, cuestionándole desde adentro y quebrantando el sistema de dominio o dentro de la destrucción total, porque intuitivamente comprende que algo está terriblemente mal en el orden establecido, o simplemente, actúa en pos de sobrevivir.
} 
Estos espacios, internos a la estructura de la casa que habitamos, aun externa a sus habitaciones principales, son los márgenes expandidos de la casa y de mi consciencia. Son espacios condensados, espacios apretados, frecuentemente espacios de almacén, de las actividades y memorias justo más allá y dentro de los principales episodios de mi vida.

Notemos que Troutman usa el vocablo "morar" muy a propósito de su significado de espacio de tránsito ${ }^{146}$. La casa inestable de Nieve, en relación estrecha con el miedo que proviene del poder patriarcal —así como la casa dejada atrás por CI—carecen de referencias al alcance de la mano como un closet, una escalera, una terraza. Dice Troutman que el miedo se le transforma en constricción: "Mis sentimientos de espacio a veces los eructo en espacios constreñidos que recuerdo o reinvento: el closet, el pasillo, el almacén del fondo, las escales estrechas hacia el sótano; a veces, en espacios grandes o vacíos" (147).

A propósito del inxilio de Nieve, lo que "mora" la joven es pura consciencia de espacio sitiado. Se nos antoja que este "morar" que apunta Troutman está estrechamente comprendido dentro de la definición que tratamos de extender para inxilio:

Me imagino que estoy construida de las varias moradas en que he vivido a través de los años; he visitado aspectos de mi casa ideal aquí y allá, la amalgama de todas mis memorias, fantasías, y asociaciones conscientes e

\footnotetext{
${ }^{146}$ En "Inside Fear. Secret Places and Hidden Spaces in Dwellings" Troutman utiliza el vocablo "morada" o "morar", en inglés "dwelling", cuyo origen del inglés antiguo, "dwellan", significa "deambular, dificultarse, demorarse". El ensayo de Troutman está incluido en un estudio más extenso sobre la relación entre espacio/arquitectura y miedo, editado por Nan Ellin: Architecture of Fear (1995). Véase desde las páginas 143 a la 157.
} 
inconscientes. Los interiores me sostienen y graban diferentes etapas de mi formación como persona. Recordar, describir, soñar despierta sobre estos espacios son maneras de sentirme completa, atisbando partes de mi misma que de otra manera se hubieran perdido. Morar, es confiar en aspectos conocidos y desconocidos de mí misma. (Troutman 157)

Nieve escoge detallar su experiencia morando el inxilio para hacer comprensible la existencia al margen del caos, el abandono, el espacio sitiado. Al otro extremo del inxilio de Nieve, la situación del país es implosiva. De modo que recurre a una abstracción espacial para preservarse, que se articula en el Diario -inxilio con aristas de ciudad abandonada.

Corren los últimos años de la década del 80 y principios de los 90, y Europa del Este se sacude las viejas banderas y redefine. Cuba expectante, se demora en reaccionar, para finalmente optar por la parálisis política y el recrudecimiento de la opresión. Lo que en un principio parecía una apertura, que esperanzara a muchos artistas e intelectuales, terminará truncándose $\mathrm{e}^{147}$. Muchos partirán hacia el exilio, abandonando la apuesta por un cambio reflejo en Cuba. De hecho, el Diario de Nieve es un documento que refleja de manera efectiva el devenir histórico del socialismo en Cuba. Sobre este aspecto relevante dice Rafael Rojas:

En el diario de Wendy Guerra, Todos se van (2006), queda registrado el momento en que se pierde aquel sentimiento de pertenencia. Ese momento, en las últimas páginas del libro, corresponde a los años 89 ,

\footnotetext{
${ }^{147}$ Dicho devenir fue un punto muerto: el llamado período especial de principios de los años 90 , marcado por una gran crisis económica. Pero el tiempo narrativo en TSV se detiene ahí. La "caída del ideal del Hombre Nuevo" (Behar 45), vemos que ya se había materializado antes de ésa década.
} 
90, 91, que marcan el fin de La Habana soviética y el inicio, no de otra Habana, sino de la diáspora, de la emigración de buena parte de los artistas y escritores de los 80. La caída del muro de Berlín estremece al personaje. (Rojas, El estante 83)

Abandonada, despojada de varias moradas, mora el espacio íntimo que articula en el Diario. Alertada sin embargo, sus apuntes se saben vigilados: "La hoja va a desaparecer en el minuto que termine de escribirla" (254). Comprendemos entonces como una indirección, el inxilio de Nieve, su "claro en el bosque" heideggereano.

Su propio nombre, Nieve, nos remite a una abstracción que la aleja de la isla, y que Nieve explica: “[...] mi madre, pensando en 'las Europas' y en las cartas de los amigos que partieron, decidió llamarme Nieve" (191). O sea, su propio nombre está cifrado en la incisión de los que se fueron. En una isla del trópico el calor no da lugar a dicha condensación atmosférica, y Nieve se pregunta: "Con este calor, ¿a quién se le ocurre ponerle ese nombre a una niña en Cuba?” (191). Pero la madre le inculca a la niña, nombrándola, una pauta a seguir -si se quiere, un modelo de abstracción en pos de la superviviencia que conviene a la hija. D este modo ser Nieve en el Diario-novela es una como alegoría, para un juego semántico de imposibilidades: No nieva en trópico, por lo que ser Nieve es casi un imposible. La alegoría nos remite a la imposibilidad de ser Nieve en la realidad. Y la posibilidad de serlo en la poesía.

Otro aspecto que ilustra cómo la protagonista se refugia en un sinlugar, es su afición a la música de los que se fueron (ahí cabe también su afición a los libros prohibidos). Gesto que la hace desertora de los himnos patrióticos y afín a los cantantes prohibidos: "prohibido poner a Carlos Varela por la canción que estrenó en el programa 
de mi madre. Parece que la palabra libertad la dijo de una manera que molesta [...] Qué linda canción" (165). De cierto modo Nieve es heredera de los mitos habaneros que Cabrera Infante ayudara a fomentar. Dentro el paradigma cabrerainfanteano, la música está estrechamente liada a la experiencia de la ciudad. Durante la niñez de Nieve en Cienfuegos, su madre era conductora radial. De hecho, algunas de las entradas del Diario, de cierto modo están organizadas como una emisión radial nostálgica, donde la relación con su madre está enmarcada por canciones y poemas: "Muchacha de ojos de papel, /adónde vas,/quédate hasta el alba./ [...] Muchacha, piel de rayón,/no corras más,/ tu tiempo es hoy" (154) — cita una canción de su preferencia.

Equidistantes están los recuerdos de la niña cuando asistía con su madre a la emisora, y hasta se quedaba dormida mientras se transmitía el programa musical de corte clásicos cubanos. De manera que, en la misma línea melómana de G, dice Nieve: "La Habana tiene sus épocas, cada una de ellas está relacionada con una canción. Así lo veo yo y así lo siento. Por eso en mi Diario las voy poniendo, para que no se desprendan de mí” (172). Por ello apuntamos la herencia de CI; la imagen anterior traza un paralelo entre cuerpo y ciudad, donde las canciones para cada época de la ciudad van "prendidas" a sí misma, de modo que la ciudad la lleva consigo. La ciudad de Nieve se alarga hacia atrás, hacia el pasado — a falta de un mejor presente y de un futuro desalentador. Pero la ciudad ya no es la ciudad de los que se fueron, aquella adscrita al espacio-temporal del cancionero de clásicos cubanos que la madre está autorizada a poner en la radio. La realidad ha sido cortada de un tajazo; la Revolución se encargó de ello mucho antes que Nieve naciera. 
A propósito de herencias, el inxilio de Nieve no quiere deberle nada a ningún mártir de la Revolución:

Cada uno de nosotros el debe "una peseta a cada mártir", dice mi madre: al asma del Che, al cuerpo de Camilo en mar, al que escribió con sangre antes de morir el nombre de Fidel en una pared, a los que mataron en Angola, a los que perdieron en Bolivia, a los mambises, a todo el mundo le debemos algo [...] Yo a quien le debo algo es mi madre y se acabó.

O sea, la joven reniega de aceptar la carga que le imputan, hasta en la herencia inmediata que recibe de su madre: "No quiero ser hippy como mi madre, no quiero Peace and Love. Quiero ser yo. Ningún estado de ebriedad me parece necesario. Tengo 15 años” (142).

Por otro lado, recordemos que la madre, como figura fundamental y contradictoria, es también quien empujara a la hija a buscar su espacio propio. De hecho, aunque Nieve no la juzgue por ello, sabe que estorba a su progenitora: "Es mejor que encuentre mi espacio en otro lado; aquí está el suyo y no puedo negarle que haga su mundo en este "proyecto de casa" como quiere, como siempre ha sido. Me rindo" (192) — escribe, mientras comparten vivienda en el solar habanero.

Acepta la joven ser desplazada de su propia casa. Habiendo tenido varias casas inestables durante su niñez accidentada, se siente incapaz de reclamarle a su madre. Baraja las opciones que le quedan sintiéndose desplazada socialmente también. Y se refugia en el Diario — vía precaria, morada reprobable también: "Si leen este Diario me odiarán” (144). Crea así una gradación de revelaciones dentro de la "transcripción 
privada" que nos llega dosificada, no llegando a fluir del todo: "No puedo describir nada más pero a la vez me desespero por contarlo todo, le temo al Diario y sus consecuencias. Le temo a lo que adoro. Tengo pánico de ser descubierta y me descubro yo misma quitando el velo" (261). El Diario es el interlocutor, que contiene el lector plausible que deberá interpretar los silencios: "Perdóname, Diario, si no escribo más, es el momento de vivir. No quiero mentir pero tampoco puedo decir lo que está pasando. Está pasando todo, esto es lo mejor que podría decir. Está entrando la mar a la ciudad y nada haré por detenerlo" (262).

Estás omisiones son deliberadas, y ella se sabe presa de esta contradicción; inmediatamente Nieve se pregunta (y nos pregunta): “¿Para qué sirve un Diario al que le mentimos" (263). Digamos que Nieve acepta que parte de su espacio virtual, su "claro en el bosque", sea confiscado, sometiéndose y adaptándose a ambigüedades verbales (e incluso ideológicas), paleadas por el respiro de libertades abstractas, pespunteadas por denuncias a medio camino de la verdad. Lo hace por momentos desde un candor que, apelando desde el Puber Aetemus (mentalidad inmadura) que, ya sea real o deliberado, nos deja atónitos. Logra de este modo un distanciamiento narrativo que traiciona la naturaleza intimista misma del medio.

En ese tono refiere sucesos brutales, como golpizas, juicios por la custodia, abandono, etc. Como cuando recuerda el día que, con nueve años, su padre la obligó a presenciar cómo éste le hacía el amor a la amante de turno — escena que ya analizamos (43). O cuando Osvaldo la desvirga, con todas las consideraciones que requiere el caso, pero dejándonos entrever en el Diario que ella es una ficha en su juego, un elemento más en el trasiego de la supervivencia de ambos dentro del sistema (210-13). Las emociones 
quedan en un segundo plano, o sepultadas bajo el velo de la inocencia. El Diario puede ser leído. Sale de ello una escritura enferma, ya no del todo subordinada al poder, ya no del todo libre.

Plasma así el registro lacerado de su vida. La accidentada biografía de Nieve Guerra proyectada al margen de una ciudad que ella sabe clausurada, limitada por el mar: "No hay forma de escapar. Todo sigue igual desde 1980; aunque pasen los años estamos varados en la misma playa” (231). Inamovible la isla después que Europa del Este se renueva — parafraseando a Iván de la Nuez - la geografía de Cuba, no ha sido derrotada por la historia (La balsa 150$)^{148}$.

Reside Nieve inxiliada dentro del espacio físico heredado, que estaba ahí antes de que se impusiera el sistema, y del que sobreviven las ruinas de una iconografía física y literaria del pasado. Un espacio físico que probablemente estará en pie, todo lo desvencijadamente posible, para sobrevivirla.

\section{Antonio marca un punto de giro dentro de la dinámica indirección/inxilio}

Mientras espera viajar a Paris casándose con Osvaldo (lo que nunca llegará a concretarse), transcurren nueve meses. Entonces conoce y se enamora de Antonio (quien viene a filmar un documental sobre Osvaldo), personaje que ofrecerá elementos nuevos en educación sentimental de Nieve. Por primera vez se siente dispuesta a compartir su secreto: le prestará los cuadernos de su Diario. Él se interesará en comentarlos: “Le parece intenso esto de hacer una vida con el Diario, piensa que es una obra tan completa como la de Osvaldo. Me pregunta por qué me mantengo en silencio. ¿De qué me

\footnotetext{
148 Dice De la Nuez, mientras analiza la geografía como arte y la revisión cartográfica que ocupa a la post modernidad, donde tantas fronteras han sido revisadas y actualizadas por el cartógrafo: "En realidad no era otro el asunto de la geografía antes de ser derrotada por la historia" (La balsa 150).
} 
escondo?" (257). Anotemos que Antonio es el primer hombre en su vida que ve como algo positivo el hecho de que Nieve lleve un diario. Incluso la anima a continuarlo y mejorarlo.

Antonio, le encomienda que lea la novela Jardín, de Dulce María Loynaz, porque Nieve le recuerda a la protagonista Bárbara, "encerrada entre las rejas de su casa" (257). Nieve descubre así a una semejante, facilitándonos una definición de inxilio:

Esa casa significa el encierro de una generación que se fue de otro modo. Enclaustrada en sus mármoles partieron estando aquí. Manteles hilo y copas puestas en el minuto exacto, como si nada hubiese sucedido, afuera la gente deshacía sus costumbres pero ellos seguían cenando a sus horas con todos los cubiertos un poco de arroz, internados en recuerdos y contando con patrimonios que se desmoronaron sin remedio. (258)

Nieve parece identificarse con la autora — aún viva en el presente narrativo:

Loynaz aún respira dentro de otra casa amurallada [...] Hoy y ahora está viva. No lo puedo creer, camino por el muro y puedo sentir el ruido de esta otra casa en ruinas. A pesar de todo sigue ahí y se ha hecho inexpugnable y necesaria, sin moverse de su espacio. (258)

El inxilio de la Nieve de WG es análogo al de Loynaz —y al de Bárbara refugiada en su jardín/inxilio: "He permanecido sola mucho tiempo, encerrada en una mansión ajena, aislada de la verdad, de lo que ocurre en esta isla, internada fuera de la realidad" (278-79).

Téngase en cuenta que en casa de Osvaldo, Nieve es vigilada de cerca por Jesús, el representante artístico del novio y especie de intermediario entre ambos, que dispone 
de los cuadros que quedaron en la casa, mientras la mantiene al tanto de la situación de su eminente partida: "Jesús es quien gobierna su vida, ¿cómo entonces puedo impedir que se lleve los cuadros?” (222). Jesús tiene derecho a entrar y salir de la mansión a su antojo: “[...] yo estaba desnuda y dormida sobre la cama $[\ldots]$ Poco a poco fue desvalijando la habitación conmigo adentro" (222). Ha de tenerse en cuenta que la casa es un privilegio atorgado a Osvaldo y no una propiedad real. El dueño de la casa es el Estado que todo lo controla; Jesús es apenas un intermediario entre el poder y Osvaldo/Nieve.

Llegan ecos sartreanos ${ }^{149}$, siendo el ser Nieve vertido en el Diario lo que es y lo que no es, plasmando la verdad de Nieve y la "deterioración" de ser Nieve. Para JaenPaul Sartre la conciencia de sí, denota una fisura donde el ser se presenta a sí mismo porque no es enteramente sí mismo (Being 77). En la autorreflexión se cuela esa fisura de la nada, como una "deterioración" de la identidad. Hemos visto como el espacio del ser Nieve se desborda del Diario, cuando el "claro en el bosque", dentro del sistema, está dado tanto por lo que anota en el Diario (incluso lo que se siente incapaz de articular), como por sus omisiones rotundas: "En este Diario está todo lo que ignoro y todo lo que sé. Ojalá algún día le encontrara respuestas a todas estas preguntas que hoy me hago" (181). En todo caso las "respuestas" no podrán anotarse, el Diario de Nieve se escribe de cara al gobierno — aunque la autora desconozca el destino final de sus apuntes. En el Diario vierte el producto doblemente "deteriorado" bajo la vigilancia y la censura, la

\footnotetext{
${ }^{149}$ Deseamos introducir aquí brevemente otra problematización del ser sartreano, para extender la noción de ser Nieve que hemos avanzado (que ya hemos abordado para analizar a G de LNI). Jean-Paul Sartre, en Being and Nothingness (1943) propone que lo que separa al sujeto de sí mismo es la nada. La nada pues, esa fisura o "deterioración" de la identidad que revela al ser en lo que es y lo que no es (16-21). Lo que presupone el aspecto oculto del ser; el "Dasein" heideggereano también atiende esos aspectos, digamos, subterráneos del ser.
} 
"transcripción privada" en conflicto, sitiada, autocensurada: "Le temo al Diario y sus consecuencias. Tengo pánico a ser descubierta" (260).

La situación empeora para Nieve, cuando inicia una relación clandestina con Antonio, en la misma casa de Osvaldo: "Dice mi amiga que no sea ingenua, que Jesús juega en dos bandos y está coqueteando con el cartel de "complicado" que tiene Antonio. Según ella debo aprender a barajar las cartas o me sacarán del juego" (259). La joven que aún no sabe "barajar las cartas", ha de encajar dentro de la "transcripción pública" para salvaguardar la "transcripción privada". Siendo el texto el nicho del ser Nieve, la joven se restituye este valor a instancias del amado: "Me ha pedido vivir y así se transforma la letra trémula, el miedo a todo" (262).

La coartada que impone la vigilancia al texto, se manifiesta en una especie de sorteo de omisiones: "Perdóname Diario, si no escribo más, es momento de vivir. No quiero mentir pero tampoco puedo decir lo que está pasando" (262). Sabemos "lo que está pasando": Se va escurriendo la década de los ochenta y con ella la esperanza de un cambio social que nunca llega a concretarse. "Lo que está pasando" para Nieve es lo que De la Nuez describe de este modo: "La Habana de los ochenta — la que Emma Álvarez Tabío clasificó como la <<década ciudadana dentro de la Revolución>>— cuando los sueños de mi generación por cambiar las cosas dentro del socialismo fueron despertados de un sopapo" (Fantasía 113). Lo que está pasando, de extraña manera, Nieve/WG logra articularlo en su libro, y en ese sentido es un testimonio.

Retomemos la circunstancia heideggereana: "Dasein", comprendemos, es portátil. Enamorada ahora de un contestatario del sistema, el ser Nieve se debate en el destello de "la verdad del arte" -representado como "el claro del boque": del Diario a la intimidad 
con el amado, dilucidándose en secreto, en el silencio minado compartido por los amantes. Una vez más, insistimos, el Diario se completa con lo que se omite, incluso con lo que Nieve no sabe expresar — siendo inexperta en los manejes de la libre expresión. El ser Nieve fabrica su nicho, acomodándose en una región virtual. Por lo que lo omitido en el Diario está a salvo, y halla su espacio, su exudación fuera de él. La reacción de Nieve a la advertencia de la amiga da fe de ello — se preserva lo que se pierde mientras se le ubique en "Dasein":

[...] cuidarme de Antonio es como cuidarme de lo que ahora quiero ser, debo seguir conservándolo en mi Diario. Si no lo veo más no puede aparecer y eso va a matarme de tristeza, me anularía. Sus besos me han colocado sobre las cúpulas, sus ideas llenan y llenan las páginas perdidas. (260)

Esta es la lógica que Nieve ofrece: si pierde al amado queda anulado su ser Nieve, por lo que ha de conservársele en el Diario. A instancias de su amado (en una carta de despedida), se siente envalentonada a formular sin ambages criterios y críticas al sistema. Para su suerte, Antonio la insta a que escriba “todo" enfrentándola con la siguiente contradicción:

Luna $^{150}$, me preocupo, sé que me vas a desdeñar por inquietarte con semejantes regaños — ¿lo son? [...] no se debería hablar sobre lo que le falta a tu Diario, que es igual que tu vida: reconocer hechos a los que le debemos atención. No se puede contar una vida si no se narran los acontecimientos que la iban marcando. ¿O es que estabas tan escondida

\footnotetext{
150 "Luna" es el apodo que Antonio da a Nieve.
} 
que nunca supiste, por ejemplo, que unos oficiales nuestros fueron fusilados por alta traición a la patria [...] Arte Calle, qué es Arte Calle, ábrele la puerta a la gente que entienda lo que puede estar pasando. (26667)

Es así como la elocución de Antonio es tal vez la parte más reveladora del Diario. Insertada ahí, apela ser la transcripción directa de una carta de despedida -amorosa y didáctica — que éste le hiciera llegar antes de caer preso debido a su disidencia política (aún antes de su partida definitiva del país). Consiste en siete páginas de consejos sobre cómo corregir y enfrentar la escritura del Diario, "que es igual que tú vida” (266), dice.

La convida a reflexionar sobre su circunstancia, a mirar fuera de sí, y explayarse en el Diario con responsabilidad histórica. Ofrece un listado extenso de lo que debería incluirse en una transcripción fidedigna de la realidad: hechos de "sangre" como guerras solidarias que marcaran la realidad cubana, cambios sociales de Europa del Este, palabras prohibidas como "Glasnost" y "Perestroika", o acontecimientos literarios como la muerte de Jorge Luis Borges, etc. Sucesos todos, cronológicamente paralelos a la vida de Nieve, que según Antonio no deben quedar fuera de sus escritos:

No colabores con la desmemoria [...] Dónde estabas tú cuando pasaba todo eso que te cuento. Dónde estás tú ahora que me guardan, qué haces, no le mientas al Diario, por favor, di la verdad siempre, es lo menos que puedes pedirte a ti misma. (271) 
El señalamiento es nuestro: Notemos que Antonio incurre en un eufemismo cuando dice "me guardan" donde pudiera decir "me llevan preso". ¿O fue la transcriptora Nieve quien censuró ciertos contenidos de la carta de Antonio ${ }^{151}$ ?

Antonio cita a Nieve mofándose de ella, y reclamándole ya en un plano más personal muchas otras omisiones. Dice imitándola: “"Mi madre ya comparte conmigo lo que antes ni se atrevía a comentar" ¿¿Qué amor!? Qué necesitamos saber que tu madre te escondía y por qué"' (270). El reclamo de Antonio surtirá efecto. De hecho, la esquela de Antonio y su arresto, sirven como catapultes del desasosiego, la asfixia, dejando a la narradora emocionalmente agotada: "que alguien me diga qué haré, estoy perdida" (272). Queda resuelta a contar, aunque sólo sea en parte, la verdad que no dijo antes, y que tal vez no sepa articular: "Querido Diario: ¿ésto es lo que merecemos? No me acorralen más, no lo soporto" (272). Tres entradas más adelante encontramos Recuento y confesión; Nieve se pronuncia sobre algunas omisiones y miedos, rectificando y completando los apuntes sobre su primer amante, Osvaldo: "Pasé estos últimos años arqueándome como una flecha sobre él, descubriéndome como una virgen cada día, aprendiendo la transfiguración que necesita una relación de dos artistas para sobrevivir" (277). Recuento y confesión, aporta más a nuestro análisis, porque Nieve trata de rectificar omisiones previas. La entrada abandona el presente narrativo para hablar desde el pretérito: "Comencé a traducir las mentiras en versiones magníficas para calmar la

\footnotetext{
${ }^{151}$ Colocar en boca de otro personaje (ya marcado como "complicado") los temas problemáticos, es lugar común en la literatura escrita bajo la señal de la censura. Apelar a un transcriptor, o a un documento hallado, ha sigo un táctica recurrente en la historia de la literatura escrita bajo sistemas de opresión. Notemos que WG recurre a un alter ego Nieve Guerra, pero ya desde el prólogo se evidencia una misma narradora para el prólogo y el resto del Diario-novela.
} 
ansiedad" (277). La joven gana perspectiva, se expande la capacidad reflexiva, indagando en otros matices de su relación con Osvaldo:

Omití del Diario las largas sesiones de confianza que me impartía el pintor. Para él fui una niña llagada por su infancia, víctima de mis padres, una criatura que necesitaba participar se su proceso de sanación. Él me restauraría la fe. Él me traería al mundo de la fantasía con sus poderes mágicos. (278)

Medita además sobre su rompimiento con la vida miserable que compartiera con su madre, marcada por las carencias materiales y la miseria:

Un terrible rechazo a lo que fui, una amenaza en aire de lo que volvería a ser. Miedo a que la carroza se convirtiera en calabaza, y a hundir mis zapatos de pana negra en el fango de esas calles deshechas y sucias. (278)

Medita sobre su retraimiento y deseo de partir dejando todo atrás, mostrándose imposibilitada $^{152}$ y culpable:

Muchas veces recibí llamadas telefónicas de algunas amigas, las que quedan. Allá afuera ellas se acostaban sin comer y yo permanecía inmóvil, sin hacer nada. Pensando solo en izar las velas y marcharme, dejando todo atrás, sin meditar en las consecuencias. (279)

De hecho, la entrada es una especie de catarsis, donde Nieve Guerra se muestra más madura, capaz de los grises que emanan de su experiencia. Es un mea culpa sin contrición:

Visité lugares lujosos, teatros alfombrados, hoteles desconocidos [...]

\footnotetext{
${ }^{152}$ Éste estado de ánimo denota la condición de inxiliada que hemos sugerido.
} 
Nunca más tuve que saltar el muro para entrar a las recepciones más selectas, pero tampoco volví a sentir el placer de bañarme desnuda y clandestina en casa de un embajador. (277)

Reconoce que accedió una vida de privilegios pagando un precio por ello: "Robaba la comida en la despensa de la casa para llevársela a mi madre, sin permiso de Osvaldo. El dinero no era mío. El patrimonio no era mío. Su mundo no era el mío” (278). Constatémoslo: "Yo, Nieve Guerra, era una replicante. Lloraba y me maquillaba, lloraba y me maquillaba. Deambulaba presagiando que las cartas eran peligrosas y que mis alas no cabían en la mansión en la que Osvaldo me había depositado" (279). Reconoce que logra salir de la burbuja de Osvaldo sustituyéndolo por Antonio: "Me enamoré de Antonio y sustituí a mi héroe en esta distancia épica y cruel, cíclica, desesperada. Se me despedazó Osvaldo [...] Antonio creció ante mis ojos, creció en el coraje de regalar su libertad y mi amor por algo visible, real" (279).

Pero tal vez, lo más subversivo de la entrada, está en que refiere su participación en los murales realizados por Arte Calle —el grupo de artistas jóvenes del que se desentendiera anteriormente ${ }^{153}-\mathrm{y}$ reconoce: "aquéllos donde me corté pintando con brocha gorda" (279). Se queja de que las autoridades hubieran tapado con pintura la muestra en graffiti sobre los muros del cementerio habanero: "aquellos que censuraron en un acto de arrebato y miedo" (279). Cabe preguntarse aquí (como tal vez inquiriría Antonio), ¿quiénes censuraron? ¿Cómo ocurrió el “arrebato" y por parte de quiénes? No

\footnotetext{
${ }^{153}$ Nieve se desentiende del grupo, al que al parecer estuvo vinculada, en una entrada anterior: "No quiero garabatear más la ciudad. Ya la ciudad es distinta con tanto verde olivo y tanto balcón caído. Tantas vallas y consignas, tantas ordenes exhortándonos desde los carteles políticos" (LNI 143).
} 
hay respuestas; el uso de la voz pasiva omite la acusación directa, repitiéndose la retórica de omisiones que hemos hecho notar.

No obstante, la caja de Pandora se abre cuando refiere la hecatombe que significó que Osvaldo pidiera asilo en París:

Sellaron la casa enseguida, así que fue imposible recoger mis pertenencias [...] Es una suerte que este Diario sea demasiado pequeño; por eso sobrevive: lo cargo a todas partes. No lloré, no lo hice porque ya he llorado demasiado por las mismas pérdidas [...] He pasado la vida conviviendo con viajes truncos, hombres que se van sin despedirse, planes que se asfixian por permisos y leyes trazadas desde el pánico. (283)

Da cuenta del interrogatorio al que la someten las autoridades: "A las diez de la noche llegaron dos desconocidos vestidos de civil y con cara de pocos amigos [...] nadie podía salvarme del interrogatorio [...] No dije lo que sabía de Osvaldo: mi entrenamiento incluye también la vergüenza y la lealtad" (282). También de cómo le retiran el pasaporte, y de la requisa al modesto apartamento de la madre: "El registro duró cuatro horas $[\ldots]$ La casa quedó hecha un desastre y los libros prohibidos nadie los advirtió" (283), refiere como si al borde del colapso emocional y psicológico.

Una bella cita de Bachelard reza: "La inmensidad en el dominio íntimo es intensidad" (Casey 95); Nieve escapa acelerada de la requisa, el miedo y las suspicacia de los policías políticos, a zambullirse en las aguas heladas del Malecón habanero. Domina así la turbulencia interna. El mar siempre le devuelve una imagen de sí, que el Diario cobijará, a veces a medias tintas, pero que terminará aclarándose en la medida de lo posible: "Este es mi turno al desencanto" (TSV 283). 
Solo a partir de la catarsis convocada por Antonio en la misiva, y precipitada por su pérdida, la ciudad aparecerá sin culpa — casi como prosopopeya: "Recordé los días que Osvaldo y yo viajábamos por la ciudad, volando entre los carros, ignorando cualquier ideología y cualquier nombre de país o de sistema” (283). La ciudad no es el sistema, no le pertenece al sistema -parece decir. Reconoce quizas, haber amado a Osvaldo: "Amarrados en dependencia a una pasión que no podía ser fatua, no podía ser mortal" (284). Se zambulle y se alivia: El ser se proyecta en la casa grande del mar, que es también un cerco geográfico, ciudad bordeada por el mar: "separando, desprendiendo mi suerte de la realidad" (184).

Husserleanamente, el ser se constata en el cuerpo — descubrimiento fundamental al despuntar de la juventud. Nieve que ha preservarse en él, sabe además que ninguna presa es inerme (valga la analogía): se da caza a lo que da señales de vida; se pasa de largo de lo inerme. Su inmovilidad ha de entenderse como anamorfosis con la ciudad, con la isla toda que es como un lagarto verde, a modo de camuflaje — presente en los reptiles, por ejemplo ${ }^{154}$. Por ello termina el relato aceptando la norma social impuesta por LA VOZ, adaptándose a la inmovilidad, aparentemente desalmada, pero salvaguardando el ser Nieve, esgrimiendo el ser Diario — como en la imagen del prólogo. El libro concluye con una imagen casi surrealista, como redención poética: mientras nada, Nieva en La Habana: "De repente una lluvia blanca empezó a caer sobre el mar. Era nieve. Nevó muy tenue, sólo para mí, por unos segundos" (284). De cualquier manera, literalmente incluso, husserleanamente, Nieve es, en cuanto a que está en La Habana. La protagonista está

\footnotetext{
${ }^{154}$ En el argot popular cubano la isla es un "lagarto verde" o "caimán verde" debido a su forma alargada análoga, vista en el mapa o desde una la vista aérea.
} 
sujeta a limitaciones análogas a las de la ciudad toda. El ser se reafirma en la ciudad, en sus aguas que son sus límites: "El mar está al fondo. Esta ciudad está sitiada por el mar" (153). Se reconoce en los bordes. Aún la inmersión de la joven puede leerse de muchas maneras. Una lectura es que, la escritora novata se arrima al lugar común de la especie, que es el regreso a la semilla, al útero materno, al agua primera — que confiere confianza en medio del caos y la desesperación. Pero esta lectura, aunque constatable, es fácil, no da en el blanco de una entramada más compleja.

Otra lectura de esta última zambullida, es la ilusión de la fuga. Fuga que la alivia de las tribulaciones del ser que habría de vivir manifestándose, mas no puede hacerlo en libertad. Nieve es una prófuga, que no ha podido escapar. De la Nuez analiza la obra del artista cubano exiliado Luís Cruz Azaceta — cuyo tema reiterativo es la balsa y el balsero - de un modo que se nos antoja conveniente traer para explicar la truncada necesidad de huida de Nieve:

Una diáspora no nos indica el tránsito entre un país y otro sino un sentido. Un estatus (que no un Estado) sin país ni banderas. Un ámbito móvil en el cual, en ocasiones, no hay orillas a la vista o, lo que es peor, las orillas avistadas pueden ser hostiles. (La balsa 161)

Es una prófuga de alma. Los que se van, son los más de dos millones que componen el éxodo cubano; ella no logra sumárseles. Entonces Nieve/WG se instala en una actitud ingenua frente al poder para atenuar su huida interna, su deserción en la fuga perpetua que alude de la Nuez. Es que Wendy Guerra se inserta con la novela dentro de la poética del éxodo cubano, desde la orilla cerrada, mensajes de humo, varada en el punto de partida. La novela es la otra cara del drama de la diáspora. 
Nieve constata su identidad, emplazada afuera, zambulléndose en las aguas de la bahía de La Habana: "Respiro hondo y siento la sal en mis bronquios. Me tranquiliza ver que puedo salir nadando hacia alguna parte. Hacia dónde no sé, pero salir nadando alguna vez para siempre" (153-54). Nadando se imagina libre, en fuga. Ese es el tris amargo de esta historia. En un tono agridulce y pesimista, queda consumado el bildungsroman de Nieve Guerra. Mientras bucea se repite mentalmente: ““'Orden, tranquilidad y silencio"” —el señalamiento, las comillas de la autora indican entonces ¿ironía?, ¿por qué parece una consigna socialista?, ¿por qué el énfasis imperativo? En cualquier caso, desde el fondo del mar, momentáneamente liberada de la carga que le confiere la representación de la "transcripción pública", la protagonista siente que quedarse inerme y callada es el camino a seguir en lo sucesivo.

De ahí que sea en las tres zambullidas rituales ${ }^{155}$ donde Nieve/ WG se calma de ser Nieve — la Wendy del cuento infantil, la narradora que se inxilia en "El País de Nunca Jamás" de una niñez aplazada. No obstante, su "transcripción privada" sitiada, el ser Diario es la conciencia social sucia pasándole la cuenta a LA VOZ hegemónica. El reclamo de Nieve, mina la conciencia colectiva sobre la que rige el protagonista inexpugnable de la dictadura. El libro de Wendy Guerra da la guerra que se esperaba de la metáfora.

Entrenada desde adolescente para una guerra contra un enemigo que no se materializa, Nieve escoge ser la perdedora de esta batalla. No ha logrado escapar, resta quedarse quieta flotando como la isla. Perder es ganar en este caso: "Uno también debería

\footnotetext{
${ }^{155}$ Notemos que son tres las zambullidas liberadoras; la primera zambullida de la niña en la bahía de Cienfuegos, cuando llega corriendo del colegio para nadar; la segunda zambullida particularmente transgresora, en la piscina en la residencia del embajador; la tercera zambullida al final del Diario-novela, en el Malecón habanero, que referimos ahora.
} 
tener la opción de perder. Yo quiero ser una perdedora si es que la otra alternativa es disparar y herir a alguien" (153). El saldo es el Diario-novela — la deserción del discurso heroico de LA VOZ - con el que la narradora insipiente se convierte en una astilla dentro la armadura del sistema.

El dilema al que se enfrenta es palpable: cómo insistir en un Diario cuando hacerlo es "Jugar con fuego. Jugar con miedo" (276). ¿Acaso traicionando al género? Lo hace acomodando al hablante, el ser Nieve, en un juego de omisiones y denuncias que tantean una esperanza generacional de apertura que nunca llega a materializarse, cuyas reglas se van aprendiendo mientras se escribe. Despojada de todo, abandonada en la isla, ensayando una huida, no dejará de escribir en el Diario, ignorando tal vez que la entrega es factual, performativa. La experiencia se baraja, Nieve se contiene; así como el cuerpo se hace liviano en el agua, se somete, hasta quedarse quieta: "De este lado sigo escribiendo el Diario, invernando en mis ideas, sin poder desplazarme, para siempre condenada a la inmovilidad" (285). 


\section{CONCLUSIONES}

El presente estudio se ha centrado en un análisis literario desde la fenomenología. Y hemos de confesar que en el proceso, lo más subyugante ha sido la metodología que hemos seguido, la manera en que la teoría interdisciplinaria es utilizada para desmenuzar la obra literaria. ¿En qué sentido nos ha guiado éste enfoque? Escogimos dos autores y sus respectivas obras muy a propósito: Hombre y mujer, el primero en el exilio — a instancias "el exilio invisible"-, la segunda inxiliada. Luego descubrimos que tanto CI

como WG son inxiliados en un espacio-temporal dislocado. Él, un autor consagrado; ella, una escritora novata. Nos dejamos llevar por los (grandes) motivos de dos novelas menores. Lo azaroso y vulnerable en estos escritos conmueve al lector avisado. LNI fue “montada” por Miriam Gómez (la viuda de CI), con retazos postreros (apuntes recurrentes que reclaman el derecho a la propiedad del pasado), pulsiones socialmente censurables, laceraciones psiquiátricas de G/CI — protagonista y autor, respectivamente. Mientras, en los intersticios de TSV se filtra el informe contra sí misma de la adolescente Nieve/GW, patología sistémica catapultada por el Estado cubano.

Las dos novelas son dos momentos en el tiempo tan estáticos, que se convierten en espacio. Sorpresivamente encontramos que el espacio se estaba reclamando desde dentro de ellas. Necesariamente dos entes de ficción lo claman: G para lidiar con lo moralmente censurable y Nieve para bandearse dentro de la censura. Asimismo, LNI se sustrae del contexto sociopolítico; TSV solo enseña la contextualización espacial que el poder le permite.

Imaginemos un eje longitudinal norte/sur conjugado en cuatro puntos cardinales, para las dos novelas estudiadas aquí. Con ésta especie de brújula virtual sugerimos los 
$360^{\circ}$ de las Habanas posibles. Al sur de LNI está la ciudadificación-de-Estela, al norte, la cinta fílmica de la memoria (el escape al reverie). En el caso de TSV tenemos, al norte, el futuro del exilio (visto desde el Malecón habanero), y al sur la sinlugaridad del inxilio. Cada eje longitudinal de la brújula sugerida: La Habana del verano de 1957 de LNI, y La Habana de la década de los 80 y principios de los 90 de TSV, existen como versiones contrastantes y complementarias de la ciudad. Una en la cinta filmica de la memoria, la otra en la sinlugaridad, donde ambos registros literarios falsifican aspectos de lo real.

Hemos deseado contribuir a las teorías del espacio habanero, desde el prisma fenomenológico. Se ha escrito demasiado de La Habana nostálgica. La Habana, cual musa orgánica resplandece en los fogonazos fílmicos de la memoria de G. La misma ciudad bordeada por el mar, pero ahora exhausta y escindida, es donde se explaya el bildungsroman de Nieve. Ambos escritores trasmiten dos épocas distintas del mismo topos, la idiosincrasia de la ciudad y de sus gentes, sus deseos y sus miedos, atrapando la esencia del lugar, dando expresión a sus entornos.

En lo que respecta a la ciudad CI lleva la delantera, pero su ciudad antonomástica no ha podido reducirse a la cinta fílmica. La Habana heredada por WG, lleva las señas de identidad de una época reciente, yuxtapuesta a lo que le precede, complementando un espacio que se extiende más allá de la ciudadificación-de-Estela de G. TSV da constancia de la grandeza perdida, pero no arquitectónicamente, sino de lo corroído en el tiempo y por el sistema. Y es que una ciudad no se puede abarcar con una sola mirada. La era revolucionaria ha implosionado la ciudad real y la virtual. Hay tantas Habanas como versiones de la misma, conformando $\operatorname{los} 360^{\circ}$ de la memoria colectiva: La ciudad algo frívola de la condesa de Merlín; el casco colonial y esclavista de Cecilia Valdés o la 
Loma del Ángel (1879) de Cirilo Villaverde; La Habana de los años 30 de la Revista Orígenes — ciudad entre Lezama Lima y Virgilio Piñera, equidistante a la actitud de sus cronistas: "resistencia estoica, que aplica al dominio de la voluntad" en el primero, resistencia "cínica" en el segundo (Álvarez-Tabío Albo 277). La ciudad de Alejo Carpentier en El acoso (1956), los jóvenes armados y dispuestos a saltar de la cama de la prostituta, de la apatía existencial, sin propósitos perdurables, del retozo estudiantil, al juego violento desde el Packard color crema. La ciudad de Tres Tristes Tigres (1964) o La Habana para un Infante difunto (1979) y la nocturnidad decadente y nostálgica que la despide en P.M. (1961); La Habana de Lunes de Revolución; el Centro Habana de Reinaldo Arenas: la ciudad dislocada y su metáfora ubicua del mar, su discurso irónico reemplazando el discurso hegemónico del Máximo Líder. Hasta que la ciudad sucumbe a la ironía cruel de la desesperanza, la indecisión moral, la ambivalencia ética, la abulia existencial de Nieve Guerra, subida al cachumbambé histórico que no da tregua. Mientras los jóvenes del 13 de marzo disparaban frenéticos hasta vaciar el cartucho sobre la alfombra del palacio, el ánimo actual sucumbe a abstracciones incongruentes y actos de repudio grotescos.

Ya a principios de los años 60, en el apogeo revolucionario, Virgilio Piñera había profetizado desde la metáfora, en un poema que dedicara a Lezama Lima, "Bueno, digamos", el silencio y el devenir escombros de la arquitectura torturada que ocupa a Antonio José Ponte a principios del nuevo milenio:

$$
[\ldots]
$$

Hemos rendido culto al sol y, algo más aún esplendoroso, 
luchamos por ser esplendentes.

Ahora, callados por un rato,

oímos ciudades deshechas en polvo,

arder en pavesa insignes manuscritos,

y el lento, cotidiano gotear del odio. (Álvarez-Tabío Albo 273)

Entonces se da el contrapunto entre la ciudad sitiada y derruída de WG con la de Pedro Juan Gutiérrez en Trilogía sucia de La Habana (1998) y los filmes Suite Habana (2003) de Fernando Pérez y Habana: Arte Nuevo de hacer ruinas (2006) de Florian Borchmeyer y Matthias Hentschler —apoyándose en el ruinólogo Ponte.

Aunque ninguno de los dos autores estudiados en esta tesis es habanero, sus propuestas contribuyen a la multiplicación de la ciudad que llegaron a vivir. Si para CI la condición de exiliado catapulta la ciudadificación-de-Estela, para WG la sinlugaridad del inxilio es pauta para el diario íntimo, que paradójicamente resulta un espacio en tensión. Las dos Habanas coexisten.

Para concluir, no hemos podido podido evitar una dimensión performativa a este esfuerso, proponiendo una investigación futura, que se plantee una Habana que tampoco existe aún. En tanto que la Revolución se definió como el pasado y el presente (según la Revolución), la Revolución secuestra la historia, para decir que todo pasado no es más un preludio a ese momento del 1ro de enero de 1959. Luego, ¿cuál es el futuro de la Revolución? La Revolución misma. Es decir, la Revolución es un eterno presente.

Pero es hora de imaginar otras Habanas posibles. A saber: Un espacio abierto para nuevas revoluciones, y asfixiante para los golpes de Estado, una ciudad hipotética que crece hasta Pinar del Río por el Oeste, y hasta Matanzas por el Este, espacio abierto 
donde La Habana es y no es testigo, una Habana que es más que ella misma, una Habana que se deja atrás, una Habana que se odia.

Despertemos a La Habana-Cancún, concentrado de comercio y puerto libre, donde hordas de exiliados cubanos oprimidos por los metaexilios se replantean la vida. La Habana-Las Vegas, capital nocturna del juego y el vicio, futuro de una Cuba-Estado51 anexada a la Unión Norteamericana. Está La Habana hipermoderna y distópica, atestada de hoteles, que se extiende hacia el oeste por el litoral hasta la mismísima playa de Varadero (un poco la de las guías de turismo de los años 50). Está La Habana-Miami yin-yang del arquitecto y profesor de la Universidad de Miami, Rafael Fornés, unidas las dos ciudades por un puente monumental Habana-Cayo Hueso, diseñado por la firma Calatrava y Co., -metrópolis diurna y ecléctica que termina siendo ciudad-puente. Está la contrafáctica, La Habana-Grozni con su guerra civil post-castrista, circa 2019. Después de un ajuste de cuentas a Raúl Castro, un triunvirato de exmilitares desbocan la isla en un golpe de Estado que provoca una guerra civil entre facciones castristas, postcastristas y anticastristas. Exiliados armados por los Estados Unidos desembarcan en Pinar del Río y Las Villas. La guerra pica y se extiende hasta 2022. Una nueva ola de balseros invade Miami en 2024 y Estados Unidos interviene en la isla en 2025, bombardeando los débiles enclaves postcastristas. Un tercio de Centro Habana y la mitad del casco renovado de La Habana Vieja quedan semidestruidos. Estados Unidos toma oficialmente La Habana en 2029.

Está La Nueva Habana, capital mesiánica, origenista y neo-barroca, sus fachadas decoradas y lustrosas, sus casonas de altos puntales con terrazas exteriores, patios interiores y coloridos vitrales filtrando la luz del trópico. La Plaza principal 
desmemoriada de su semiótica socio-política. O la ciudad criolla blanca, acaso mulata, tradicional y pujante, imaginada en un tratado como Instructiones Fabricae Et Supellectilis Ecclesiasticae del cardenal barroco Carlo Borromeo, sobrino del Papa Pío IV. Otra Habana posible es la de Severo Sarduy en De donde son los cantantes (1967), Habana-collage ciudadificándose en constantes reencarnaciones y transfiguraciones. Habana casi negra, dislocada y anacrónica, rural y citadina, ruinosa y post-post-moderna. Las ciudades las hacen los seres que las habitan, y tal vez con mayor ahínco y vocación pedestre y desalmada, los desplazados y los sometidos, los que las parodian, los que las imaginan. Ojalá los espacios convocados aquí sirvan de incentivo para atrapar la ciudad plausible. En tanto que París sea "en efecto la creación de Guy de Maupassant" (CI, El libro 63), cabe imaginarnos todas Las Habanas futuras posibles. 


\section{BIBLIOGRAFÍA}

Álvarez-Tabío Albo, Emma. Invención de La Habana. Barcelona: Editorial Casiopea, 2000.

Bachelard, Gaston. La poética del espacio. México, D. F.: Fondo de Cultura Económica, 2006.

---. The poetics of Reverie. Boston: Beacon Press, 1969.

Behar, Sonia. La caída del hombre Nuevo: Narrativa cubana del período especial. Miami: Florida International University, 2007.

Benjamin, Walter. Reflections. Essays, Aphorisms, Autobiographical Writings. New York: Schocken Books 1986.

---. Illuminations. Essays and Reflections. New York: Schocken Books, 1969.

Bergson, Henri. Obras completas. Madrid: Editorial Aguilar, 1963.

Bloom, Harold. The Anxiety of Influence: A Theory of Poetry. New York: Oxford University Press US, 1997.

Boym, Svetlana. The Future of Nostalgia. New York: Basic Books, 2001.

Cabrera Infante, Guillermo. Cuerpos divinos. Barcelona: Galaxia Gutenberg, 2010.

---. La ninfa inconstante. Barcelona: Galaxia Gutenberg, 2008.

---. Exorcismos de estilo. Madrid: Punto de Lectura, 2002.

---. El libro de las ciudades. Madrid: Alfaguara, 1999.

---. Infantería. Eds. Nivia Montenegro y Enrico Mario Santí. México, D. F.: Fondo de Cultura Económica, 1999.

---. Cine o sardina. Madrid: Alfaguara, 1997.

---. Ella cantaba boleros. Madrid: Alfaguara, 1996.

---. Mea Cuba. Barcelona: Janés Editores, 1992.

---. Tres tristes tigres. Barcelona: Editorial Seix Barral, 1991.

---. La Habana para un Infante difunto. Barcelona: Plaza Janés, 1989. 
---. "El exilio invisible." <www.elpais.com> 13 de mayo de 1983.

Cámara, Madeline. "Antología y estudio de Ena Lucía Portela”, <www.elnuevo.com> 18 de abril de 2010.

---. Cuban Women Writers: Imagining a Matria. New York: Palgrave Macmillan, 2008.

---. La letra rebelde. Estudios de escritoras cubanas. Miami: Ediciones Universal, 2002.

Casey, Edward S. The Fate of Place. Los Angeles: University of California Press, 1997.

Castro, Fidel. "Palabras a los intelectuales." <www.min.cult.cu> Junio de 1961.

De la Nuez, Iván. El mapa de sal. Cáceres: Editorial Periférica, 2010.

---. Fantasía roja. Barcelona: Random House Mandadori, 2006.

---. La balsa perpetua. Barcelona: Editorial Casiopea, 1998.

Decíu Rítívoí, Andreea. Yesterday's Self. Nostalgia and the Immigrant Identity. Cumnor Hill, Oxford: Rowman \& Littlefield Publishers, Inc., 2002.

Deleuze, Gilles. Bergsonism. New York: Zone Books, 1988.

Descartes, René. Descartes: Philosophical Letters. Oxford: Clarendon Press, 1970.

Díaz, Duanel. Palabras del trasfondo. Madrid: Editorial Colibrí, 2009.

Directorio Telefónico de La Habana. La Habana: HABA-DOM CORP, abril de 1958.

Duarte Oropesa, José. Historiología cubana: Desde 1944-1959, Miami: Ediciones Universal, 1974.

Foucault, Michel. Discipline \& Punish. The Birth of the Prison. New York: Vintage Books Edition, Random House, 1979.

Fornés, Rafael. "Rafael Fornés y La Habana del presente y del futuro." $<$ www.tumiamiblog $>7$ de julio de 2009.

Franqui, Carlos. Cuba, la Revolución: ¿Mito o realidad? Barcelona: Ediciones Península, 2006.

Fuentes, Ileana. Cuba sin caudillos. Un enfoque feminista para el Siglo XXI. Texas: 
Linden Lane Press, 1994.

García Huidobro, Cecilia. Autorretrato. Santigo de Chile: Ediciones de la Pontificia Universidad Católica de Chile, 1993.

Gil López, Ernesto. Guillermo Cabrera Infante: La Habana, el lenguaje y la cinematografía. Islas Canarias, Tenerife: Universidad de La Laguna, 1987.

Guerra, Wendy. Nunca fui primera dama. Barcelona: Bruguera, 2008.

---. Todos se van. Barcelona: Bruguera, 2006.

Grosz, Elizabeth. "Bodies-Cities". Sexuality \& Space. Ed. Beatriz Colomina. New York: Princeton Press on Architecture, 1992.

Harguindey, Ángel S. "La ninfa inconstante, novela de Cabrera Infante sin publicar, verá la luz a principios de año." <www.elpais.com> 9 de noviembre de 2007.

Heidegger, Martin. El ser y el tiempo. México D. F.: Fondo de Cultura Económica, 2000.

---. Being and Time. New York: Harper \& Row, Publishers, 1962.

---. "El origen de la obra de arte". Poetry, Language, Thought. New York: Harper \& Row, Publishers, 1975.

Hernández Lima, Dinorah. Versiones y re-versiones históricas en la obra de Cabrera Infante. Madrid: Editorial Pliegos, 1990.

Ilie, Paul. Literature and Inner Exile. Baltimore: The Jonh Hopkins UP, 1980.

Jackson, Anna. Diary Poetics. Form and Style in Writer's Diaries, 1915-1962. New York: Routledge, 2010.

Kant, Immanuel. Critique of Pure Reason. New York: Humanities Press, 1960.

Kruft, Hanno-Walter, A History of Architectural Theory. Princeton: Princeton Architectural Press, 1994.

López, Ángeles. Trastorno Afectivo Bipolar: La enfermedad de las emociones. Madrid: Editorial EDAF, S. A., 2003.

Martín Zequeira, María Elena y Eduardo Luis Rodríguez Fernández. La Habana. Guía de arquitectura. Junta de Andalucía, Cuidad de La Habana: Dirección de Planificación Física y de Arquitectura, 1998. 
Merleau-Ponty, Maurice. Phenomenology of Perception. London: Routledge, 1994.

Pereda, Rosa M. Guillermo Cabrera Infante. Madrid: EDAF, 1979.

---. Mi música extremada. Madrid: Espasa Calpe, 1996.

Piñera, Virgilio. "Bueno, digamos", en La isla en peso. La Habana: UNEAC, 1998. 160.

Platón. Diálogos. México, D. F.: Editorial Porrúa, 1996.

Ponte, Antonio José. Villa Marista en plata. Arte, política, nuevas tecnologías. Madrid: Editorial Colibrí, 2010.

---. La fiesta vigilada. Barcelona: Editorial Anagrama, 2007.

Porter Abbott, H. Diary as Fiction. Writing as Action. Ithaca: Cornell University Press, 1984.

Pym, John. Time Out. Film Guide. London: Time Out Universal Guides Ltd., 2000.

Quiroga, José. "Boleros, Divas, and Identity Motels". Cuba, the Elusive Nation. Eds. Damián J. Fernández y Madeline Cámara. Gainesville: University Press of Florida, 2000. 116-33.

Raymond, D. Souza. Guillermo Cabrera Infante: Two Islands, Many Words. Texas: University of Texas Press, 1996.

Rodríguez, Eduardo Luis. The Havana Guide. Modern Architecture, 1925-1965. New York: Princeton Architectural Press, 1999.

Rojas, Rafael. El estante vacio. Literatura y política en Cuba. Barcelona: Editorial Anagrama, 2009.

---. Tumbas sin sosiego. Barcelona: Editorial Anagrama, 2006.

---. La política del adiós. Miami: Ediciones Universal, 2002.

---. El arte de la espera. Madrid: Editorial Colibrí, 1998.

Rosen, Steven M. Topologies of the Flesh: A Multidimensional Exploration of the Lifeworld. Ohio: Ohio University Press, 2006.

Rundle, Bede. Time, Space, and Metaphysics. New York: Oxford University Press, 2009. 
Santí, Enrico Mario. “Cabrera Infante: El estilo de la nación.” <www.letraslibres.com> Abril de 2005.

Sartre, Jean-Paul. Essays in Existentialism. New York: Citadel Press, 1993.

---. Being and Nothingness. New York: Random House, 1994.

Schilpp, Paul Arthur. The Philosophy of Jean-Paul Sartre. Chicago: Open Court, 1981.

Scott, James C. Domination and the Arts of Resistance. Hidden Transcripts. New Heaven: Yale University Press, 1990.

Ströker, Elisabeth. Investigations in Philosophy of Space. Ohio: Ohio University Press, 1987.

Triff, Alfredo. Higado al ensayo. 60 recetas biliares. Miami: Dada Editores, 2010.

Troutman, Anne. "Inside Fear. Secret Places and Hidden Spaces in Dwellings". Architecture of Fear. Ed. Nan Ellin. Princeton: Princeton Architectural Press, 1995. 143-57.

Todes, Samuel. Body and World. Cambridge: The MIT Press, 2002.

Violich, Francis. "Towards revealing the sense of place: An intuitive 'reading' of four Dalmatian towns." Dwelling, Place \& Environment. Towards a Phenomenology of Person and World. Eds. David Seamon y Robert Mugerauer. New York: Columbia University Press, 1989.

Wilson, Elizabeth. The Sphinx in the City. Urban Life, the Control of Disorder, and Women. Los Angeles: University of California Press, 1991. 
VITA

ROSA M. INGUANZO

1999-2001

2002-2005

B.A., Spanish, Magna Cum Laude Florida International University

Miami, Florida

Teaching Assistant

Florida International University

Miami, Florida

2004

Department Chair's Assistant

FIU, Department of Modern Languages

Miami, Florida

2004

M.A., Spanish

Florida International University

Miami, Florida

2011

Doctoral candidate in Spanish

Florida International University

Miami, Florida

\section{PUBLICATIONS AND PRESENTATIONS}

Inguanzo, Rosa M. Deseoe donde se era. Madrid: Nos y Otros Editores, 2000.

Inguanzo, Rosa M. Palabras en el fuego: creadores de Miami dicen. Miami: Florida Center for the Literary Arts, MDC, 2004.

AWARDS

2002

Outstanding Academic Achievement Award

Florida International University

Miami, Florida 